\author{
UNIVERSIDADE DE SÃO PAULO \\ ESCOLA DE ENGENHARIA DE SÃO CARLOS \\ DEPARTAMENTO DE HIDRÁULICA E SANEAMENTO
}

RODRIGO SOARES GARCIA DA SILVA

\title{
CONCEPÇÃO E AVALIAÇÃO DO DESEMPENHO DE UM REATOR ANAERÓBIO DE MANTA DE LODO DOTADO DE AGITAÇÃO COM JATOS E DECANTADOR DE ALTA TAXA TRATANDO ESGOTO SANITÁRIO
}

VERSÃO CORRIGIDA

São Carlos - SP 


\title{
CONCEPÇÃO E AVALIAÇÃO DO DESEMPENHO DE UM REATOR ANAERÓBIO DE MANTA DE LODO DOTADO DE AGITAÇÃO COM JATOS E DECANTADOR DE ALTA TAXA TRATANDO ESGOTO SANITÁRIO
}

Tese apresentada à Escola de Engenharia de São Carlos, da Universidade de São Paulo, como parte dos requisitos para obtenção do título de Doutor em Ciências: Engenharia Hidráulica e Saneamento.

ORIENTADOR: Prof. José Roberto Campos

\author{
VERSÃO CORRIGIDA \\ São Carlos - SP


AUTORIZO A REPRODUÇÃO TOTAL OU PARCIAL DESTE TRABALHO, POR QUALQUER MEIO CONVENCIONAL OU ELETRÔNICO, PARA FINS DE ESTUDO E PESQUISA, DESDE QUE CITADA A FONTE.

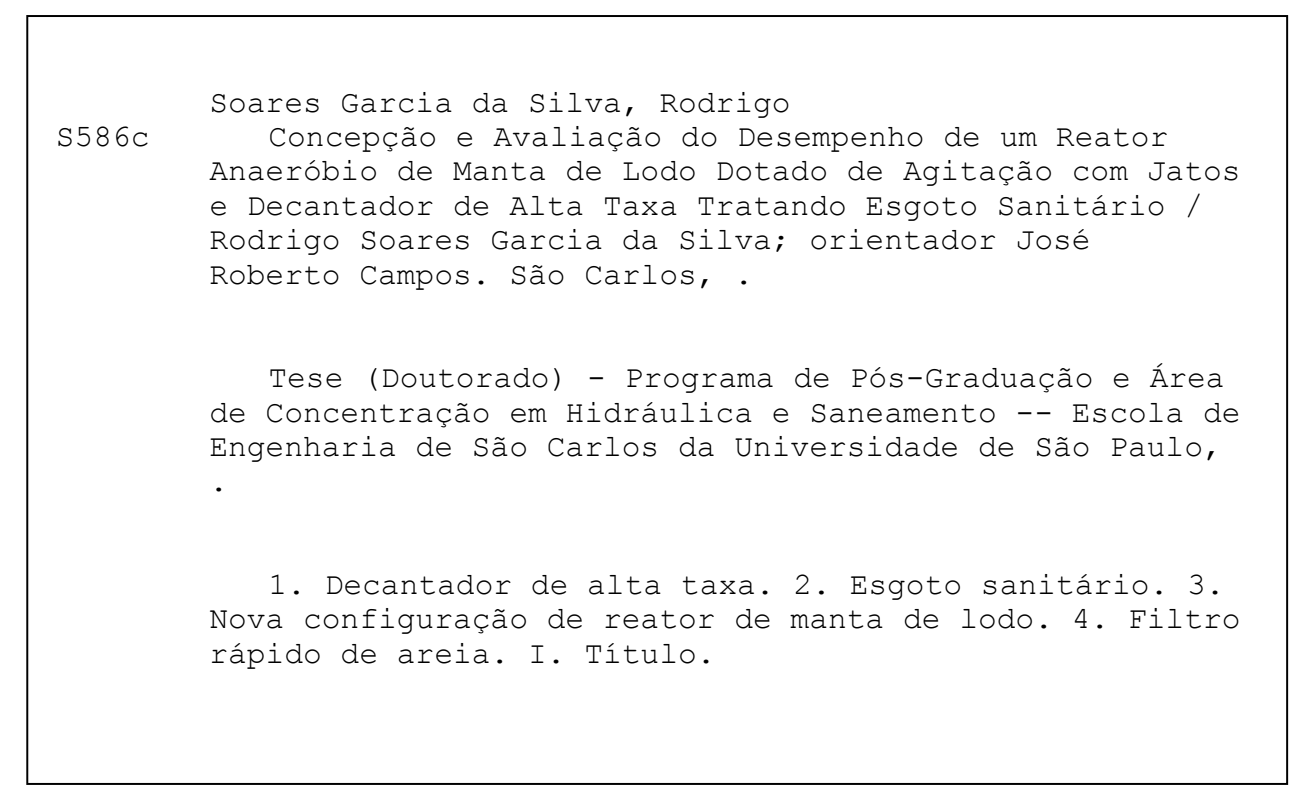


FOLHA DE JULGAMENTO

Candidato: Engenheiro RODRIGO SOARES GARCIA DA SILVA.

Título da tese: "Concepção, execução e operação de reator anaeróbio dotado de agitação no setor de reação promovida por jatos tratando esgoto sanitário".

Data da defesa: 24/04/2015

\section{Comissão Julgadora:}

Prof. Titular José Roberto Campos (Orientador)

(Escola de Engenharia de São Carlos/EESC)

Prof. Dr. Adrianus Cornelius Van Haandel

(Universidade Federal de Campina Grande/UFCG)

Prof. Titular Roque Passos Piveli

(Escola Politécnica-EP/USP)

Dra. Leila Jorge Patrizzi

(Serviço Autônomo de Água e Esgoto/SAAE)

Prof. Dr. Luiz Antonio Daniel

(Escola de Engenharia de São Carlos/EESC)
Resultado:
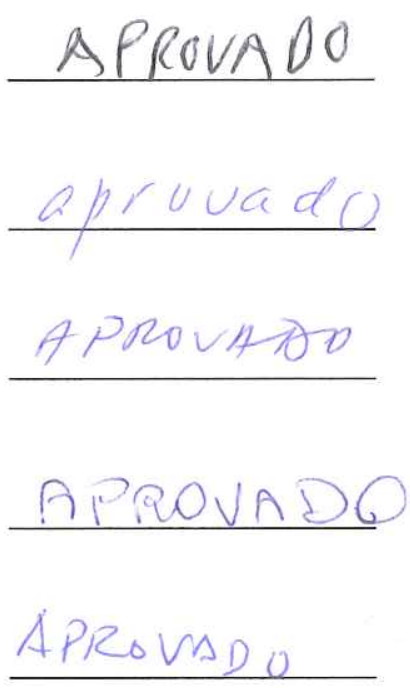

Coordenadora do Programa de Pós-Graduação em Engenharia Hidráulica e Saneamento:

Profa. Associada Maria Bernadete A. Varesche Silva

Presidente da Comissão de Pós-Graduação:

Prof. Associado Paulo César Lima Segantine 

"Deleite-se no Senhor, e ele atenderá aos desejos do seu coração" 
Página intencionalmente deixada em branco. 


\section{Dedicatória}

Às pessoas mais ilustres da minha vida, que nunca pouparam esforços para me proporcionarem a chance de realização deste e de todos outros sonhos, minha mãe Odinéia e meu pai Ademir. 
Página intencionalmente deixada em branco. 


\section{Agradecimentos}

À minha família - meu pai, minha mãe e meu irmão André - pessoas essenciais, as quais estiveram sempre ao meu lado em todos os momentos, desde o início desta caminhada. Obrigado pai, mãe e irmão pelo amor incondicional, vocês formam a base da minha vida. Sou grato a vocês pelo total incentivo que me proporcionaram.

Às minhas avós (Eugênia e Maria), tios e tias, agradeço a força e palavras de apoio e estímulo. Mesmo distantes se fizeram presentes em todos os momentos por meio de muitas conversas, devido a isso minha caminhada tornou-se mais leve e agradável.

Aos meus primos, irmãos de coração, que sempre estiveram ao meu lado (Ana, Anelise, Beatriz, Chistiano, Gabriel, Giovany, Luciano, Marcelo, Rafael, Stephany, Thiago, Vanessa).

À minha companheira e amiga Fernanda, por estar comigo diariamente tornando meus dias mais felizes, pela ajuda em minha caminhada pessoal e profissional, trazendo força e apoio quando mais precisava.

Ao professor Dr. José Roberto Campos, meu orientador. Obrigado pelo conhecimento repassado, pela paciência, ajuda, incentivo, compreensão e ensinamentos.

Aos meus amigos do Laboratório de Microssensores, Aurélia, Beatriz, Nayara, Wagner e em especial ao parceiro de pesquisa Bruno Pessotto. Sou grato pela troca de conhecimento, ajuda e momentos de entretenimento.

À Cecília, Fernanda, Flávia, Márcia, Maria Teresa, Rose, Valderez, pelo bom convívio e disposição para sempre auxiliar.

Aos profissionais do Laboratório de Saneamento, Júlio, Cidinha, Paulo, Bianca, Sabrina e Aline, por toda colaboração na realização dos ensaios laboratoriais.

Ao André Tognon da Central de Análises Químicas Instrumentais (IQSC/USP) e aos Srs. José Luís e Oscar Neto do Departamento de Geotecnia (EESC/USP) pela cooperação e empréstimo de equipamentos.

Aos funcionários do SAAE-São Carlos pela prontidão e auxílio prestados nas coletas de inóculo para pesquisa.

À Mineração Jundu Ltda. pelo fornecimento do meio filtrante utilizado na pesquisa.

À CAPES (Coordenação de Aperfeiçoamento de Pessoal de Nível Superior) e ao CNPQ (Conselho Nacional de Desenvolvimento Científico e Tecnológico) pelas bolsas concedidas. À FAPESP (Fundação de Amparo à Pesquisa do Estado de São Paulo) pelo auxílio pesquisa 2010/51824-5. 
Aos amigos, que apesar de não contribuírem diretamente, sempre deram ânimo para conclusão da empreitada:

- os velhos amigos dos tempos de guri, Caio, Fernando, Giancarlo, Roger, Wilson.

- os amigos do tempo da faculdade, Aline, Bruno Coelho, Bruno Faria, Camilo, Carlão, Gustavo (Becker), João Rafael (Jatobá), Leandro, Marjolly.

- as amizades forjadas no doutorado Deivid (Buchecha), Ivie, Priscila, Vinicius (Bidjei), Vitor (Madruga); em especial ao Piu (Guilherme Barbosa) um irmão que tanto me "socorreu" e com quem tanto aprendi durante esses cinco anos.

- a amizade "forçada", Renata Genova.

- a grande família Xêro, Osvaldo (Nego), Matheus (Tetinha), Rodrigo (Beldade), Guilherme ("Montro"), Willame (Quixera), Rodrigo (Bobo), Nayara, Tiago (Cebola), Paulo (Pauleta), Arthur (Irlanda), Marcus, Davi (Legal), Zé, Felipe (Seu Jorge), Felipe (Mineiro), Fernando (Tchê), Loide, Phillipe (Alecrim), Samuel (Chamego).

- a amizade da vira-latinha caramelo, a Flor, o único ser a quem gostava de recorrer em certos momentos.

Finalmente agradeço à Deus, por minha vida, por minha fé, por dar-me forças diariamente e por sustentar-me nos momentos difíceis, sem Ele nada disso faria sentido. 


\section{RESUMO}

SILVA, R. S. G. Concepção e avaliação do desempenho de um reator anaeróbio de manta de lodo dotado de agitação com jatos e decantador de alta taxa tratando esgoto sanitário. $166 \mathrm{f}$. Tese (Doutorado) - Escola de Engenharia de São Carlos, Universidade de São Paulo, São Carlos, 2015.

Os reatores UASB (upflow anaerobic sludge blanket reactors) foram um marco histórico no tratamento de efluentes ao propiciar alta retenção de sólidos e boa mistura entre biomassa e afluente. Apesar de os reatores com a concepção original dos UASB serem usados com sucesso em muitas estações de tratamento de esgoto, algumas questões relacionadas a sua operação, construção e manutenção ainda prevalecem. Sendo assim, novas configurações baseadas na concepção tradicional de reatores de manta de lodo podem simbolizar novas tentativas para sanar essas questões. Neste contexto, uma configuração que emprega manta de lodo, objetivando principalmente a eliminação dos separadores trifásicos e adoção mistura com jatos, é aqui proposta, almejando simplificar a distribuição/mistura do esgoto afluente. A pesquisa foi, assim, realizada primeiramente em escala de bancada para determinar do gradiente de velocidade médio necessário para suspensão de sólidos, resultando em valores favoráveis de até $20 \mathrm{~s}^{-1}$. Na segunda fase, uma instalação piloto de $2,69 \mathrm{~m}^{3}$, construída em acrílico, foi utilizada para o estudo das características do jato e dos bocais, e do regime de mistura proporcionado pelo mesmo. Com auxílio das informações obtidas na primeira e segunda fases, a terceira fase do experimento abrangeu a reforma de um reator UASB tradicional, em escala piloto de $20,8 \mathrm{~m}^{3}$, para a implantação desse novo sistema de tratamento: removeram-se os sistemas para coleta de gases e de distribuição de fundo e implantou-se alimentação intermitente por meio de jatos, além de unidade de decantador de alta taxa. Em essência, o novo sistema foi dividido em duas zonas distintas: uma para as reações e outra provida de decantação laminar para a remoção de sólidos suspensos. Na primeira zona, a entrada de esgoto sanitário deu-se por meio de bocal que proporcionou jato para mistura da manta de lodo através da carga manométrica fornecida por reservatório elevado. A velocidade de entrada no reator e o alcance do jato puderam ser determinados, constatando-se que o número de pontos de entrada no reator pode ser reduzido (em relação ao número de pontos recomendados tradicionalmente: 2 a $4 \mathrm{~m}^{2}$ por ponto). $\mathrm{O}$ gradiente de velocidade aplicado durante cada jato (com 30 segundos de duração) foi de $16,6 \mathrm{~s}^{-1}$. Para o reator da terceira fase, na fase estável da operação, obteve-se eficiência de remoção de 52,79\%, 70,90 \% e 47,00\% para DQO, DBO e SST, respectivamente. Adicionalmente, avaliou-se o uso de filtro rápido de camada única de areia para o póstratamento do efluente do reator anaeróbio, cujas remoções de DQO, SST e Turbidez (para taxa de aplicação de $100 \mathrm{~m}^{3} \cdot \mathrm{m}^{-2} \cdot \mathrm{dia}^{-1}$ ) foram de $54,94 \%, 84,44 \%$ e $81,71 \%$ respectivamente. Concluiu-se, desta forma, a viabilidade da operação do reator de manta de lodo com alimentação intermitente e sem necessidade de instalação do sistema separador trifásico.

Palavras - chave: Decantador de alta taxa, esgoto sanitário, nova configuração de reator de manta de lodo, filtro rápido de areia. 
Página intencionalmente deixada em branco. 


\begin{abstract}
SILVA, R. S. G. Design and performance evaluation of an upflow anaerobic sludge blanket provided with agitation jets and high rate sedimentation treating domestic sewage. 2015. $166 \mathrm{f}$. Tese (Doutorado) - Escola de Engenharia de São Carlos, Universidade de São Paulo, São Carlos, 2015.

Os reatores UASB (upflow anaerobic sludge blanket reactors) foram um marco histórico no tratamento de efluentes ao propiciar alta retenção de sólidos e boa mistura entre biomassa e afluente. In spite of reactors with the original design of UASB are successfully used in many wastewater treatment plants, some issues regarding the operation, construction and maintenance of these reactors still prevail. Thus, new configurations based on the traditional conception of sludge blanket reactors may signify new tries to solve these issues. In this context, this research proposes a new configuration, using sludge blanket, mainly aiming at the elimination of the three-phase separators and adoption of a mixture through jets in order to simplify distribution / mixing of the influent. Therefore firstly a bench scale study was conducted to determine the required average velocity gradient for suspension of solids, resulting in favorable values up to $20 \mathrm{~s}^{-1}$. In the second phase, a $2.69 \mathrm{~m}^{3}$ pilot plant was built in acrylic to study the characteristics of the jet and the nozzles, and the resulting mixing state. After this stage, and with the contribution of information obtained in the earlier stages, a traditional pilotscale UASB reactor of $20.8 \mathrm{~m}^{3}$ was adapted for the implementation of this new treatment system: the systems for gas collection and distribution of background were removed, and a high-rate sedimentation unit and intermittently feed through jets were introduced. In essence, the new system has been divided into two distinct zones: one for reactions and other provided of laminar decantation to remove suspended solids. In the reaction zone the entry of sewage was given through jet for mixing the sludge blanket. The mixing energy was provided by jet stemmed on an elevated tank, where the sewer was accumulated. The jet range and entry velocity into the reactor could be determined, noting that the number of entry points in the reactor can be reduced (relative to the number of points traditionally recommended: 2 to $4 \mathrm{~m}^{2}$ per point). The velocity gradient applied during each jet (with a 30 seconds duration) was 16.6 $\mathrm{s}^{-1}$. The pilot-scale reactor (third phase), in stable-phase operation, got a removal efficiency of $52.79 \%, 70.90 \%$ and $47.00 \%$ for COD, BOD and TSS, respectively. Additionally, were evaluated the use of unique coating rapid sand filter to the post-treatment of the effluent in the anaerobic reactor. The removals obtained for COD, TSS and Turbidity (for application rate of $100 \mathrm{~m}^{3} \cdot \mathrm{m}^{-2} \cdot \mathrm{dia}^{-1}$ ) were $54.94 \%, 84.44 \%$ and $81.71 \%$ respectively. It was concluded, therefore, the viability of the sludge blanket reactor operation with intermittent feed and without threephase separator system installation.
\end{abstract}

Keywords: High rate sedimentation, new configuration of sludge blanket reactor, rapid sand filtration, sewage. 
Página intencionalmente deixada em branco. 


\section{LISTA DE FIGURAS}

Figura 3.1: Esquema típico representando reator UASB, conforme concebido por Lettinga et

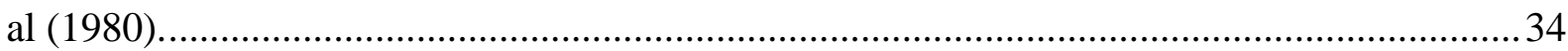

Figura 3.2: Corrosão em canaletas do efluente de um reator UASB (SANASA). ................... 42

Figura 3.3: Avaliação da funcionalidade do tratamento preliminar ao UASB (adaptado de

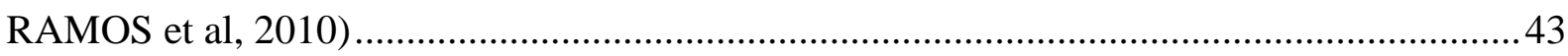

Figura 3.4: Frequência de descarte de lodo dos reatores UASB (RAMOS et al, 2010)...........43

Figura 3.5: Frequência de remoção de escuma dos reatores (RAMOS et al, 2010)................. 43

Figura 3.6: Exemplo de quantificação de metano dissolvido no efluente (HEFFERNAN et al,

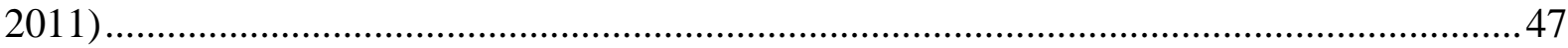

Figura 3.7: Esquema típico de um reator ABR (adaptado de NNAJI, 2014).......................... 48

Figura 3.8: Esquema representando as diferenças do reator UASB (esquerda) e o reator EGSB (direita), (adaptado de SEGHEZZO, 2004)....................................................................... 49

Figura 3.9: Desenvolvimento de um jato simples e sua propagação de velocidades ao longo do

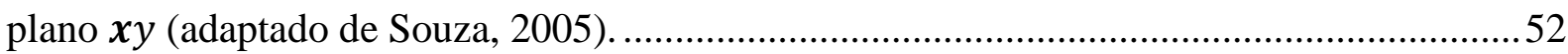

Figura 3.10: Experiência de Venturi (AZEVEDO NETTO, 1998) ........................................53

Figura 3.11: Coeficientes de contração, velocidade e descarga para cada aplicação de bocais

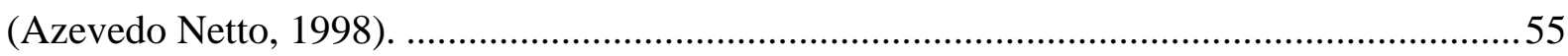

Figura 3.12: Bocais cônicos a partir de uma angulação $\boldsymbol{\theta}$ (Porto, 2006). ................................ 56

Figura 3.13: Exemplos comerciais de sistemas agitadores por jatos: A) Siemens, B) Mixing

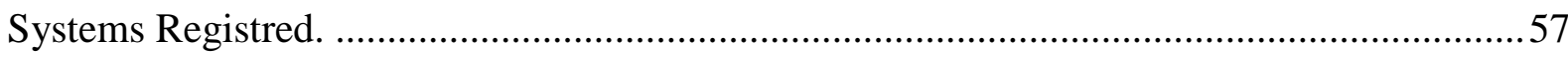

Figura 3.14: Exemplo de jato de água proporcionado pela adição de um bocal na extremidade

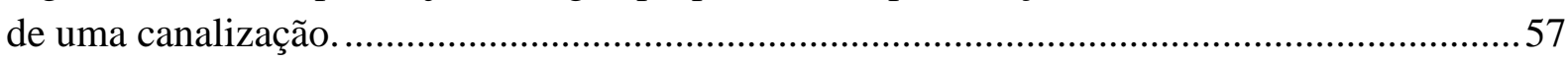

Figura 3.15: Representação da agitação causada por jato horizontal(a) e por jato inclinado(b), (adaptado de PATWARDHAN E GAIKWAD, 2003).

Figura 3.16: Representação da agitação causada por bocais inclinados a $0^{\circ} ; 45^{\circ}$ e $30^{\circ}$

respectivamente, em relação à parede lateral do tanque (adaptado de KALAICHELVI et al, 2007).

Figura 3.17: Variação da velocidade $\left(\mathrm{m}_{\mathrm{s}} \mathrm{s}^{-1}\right)$ dos jatos no interior de um tanque, e influência na agitação deste (adaptado de ZUGHBI, 2007).

Figura 4.1: Comparação do sistema de alimentação: (a) reator convencional (Agricultural University Of Wageningen, 1994); (b) sistema empregando jatos misturadores.

Figura 4.2: Estação de Tratamento de Esgoto da EESC/USP, local de desenvolvimento de

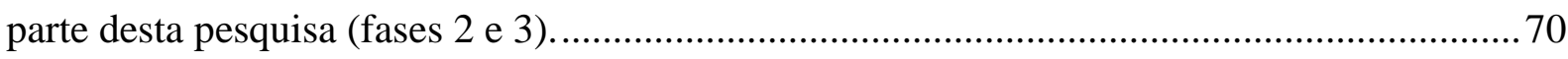

Figura 4.3: Fluxograma das fases experimentais................................................................. 71

Figura 4.4: Reatores de bancada onde foi avaliada a energia de agitação. (1 e 2) reatores agitados; (3) reator de controle para avaliar perda de biomassa somente por arraste. .............72

Figura 4.5: Bocal utilizado para promover mistura nos reatores............................................ 74

Figura 4.6: Tanque de acrílico para testes preliminares com os bocais submersos.................. 75

Figura 4.7: Reservatório elevado e válvula de abertura rápida utilizados para gerar

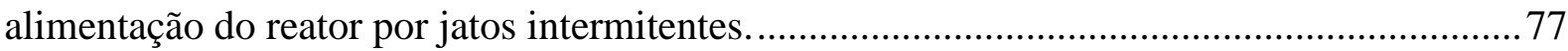

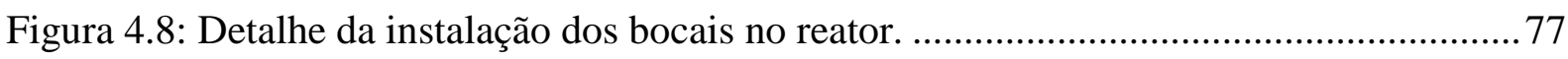


Figura 4.9: Fluxograma das unidades de tratamento utilizadas na terceira fase da pesquisa... 82

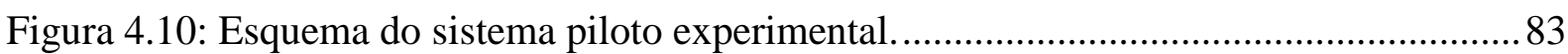

Figura 4.11: Esquema com visão geral do sistema piloto ante a Estação de Esgoto da USP. . 84 Figura 4.12: Detalhe e esquema do decantador de alta taxa instalado na saída do reator........ 86 Figura 4.13: Sistema de descarte de lodo do fundo do decantador e retorno ao reservatório

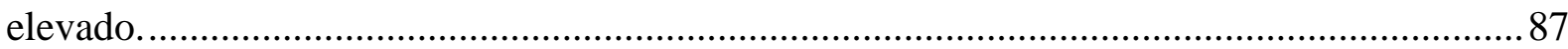

Figura 4.14: Detalhe do piezômetro instalado à montante do bocal na tubulação de

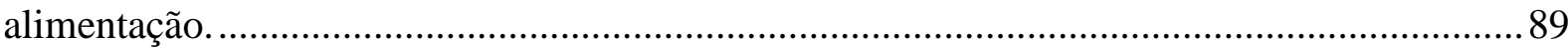

Figura 4.15: Dimensões do reator utilizadas no cálculo da potência de agitação aplicada ......91

Figura 4.16: Montagem de laboratório para teste AME...................................................... 94

Figura 4.17: Fotografia e desenho esquemático do filtro de areia descendente. .....................97

Figura 4.18: Curva de distribuição granulométrica do meio filtrante. .....................................98

Figura 4.19: Características granulométricas do leito de filtração e da camada suporte..........99

Figura 5.1: Valores de DQO na entrada e saída dos reatores de bancada. .............................. 102

Figura 5.2: Aplicação dos jatos turbulentos na alimentação do reator.................................... 104

Figura 5.3: Curva de distribuição de tempo de residência para o TDH de 6,25 h................. 106

Figura 5.4: Representação da curva DTR para escoamento com tendência à mistura completa

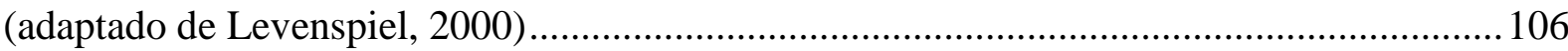

Figura 5.5: Curva de distribuição do tempo de residência para a solução salina aplicada ao

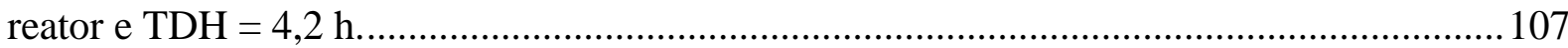

Figura 5.6: DQO das amostras brutas na entrada e saída do reator....................................... 112

Figura 5.7: DQO das amostras brutas na entrada e saída do decantador de alta taxa. ...........113

Figura 5.8: Eficiência de remoção de DQO no decantador de alta taxa................................ 113

Figura 5.9: DQO das amostras brutas na entrada e saída do sistema piloto........................... 114

Figura 5.10: Eficiência de remoção de DQO pelo sistema piloto. ........................................ 114

Figura 5.11: Valores de DQO de amostras filtradas na entrada e saída do reator................... 116

Figura 5.12: Eficiência de remoção de DQO de amostra filtrada no reator. ...........................116

Figura 5.13: Valores de DQO de amostra filtrada na entrada e saída do decantador.............117

Figura 5.14: Eficiência de remoção de DQO de amostra filtrada no decantador................... 117

Figura 5.15: Valores de DQO de amostra filtrada na entrada e saída do sistema global.......118

Figura 5.16: Eficiência de remoção de DQO de amostras filtradas no sistema global. .........118

Figura 5.17: Valores de DBO na entrada e saída do reator. ................................................ 120

Figura 5.18: Valores de DBO na entrada e saída do decantador.......................................... 120

Figura 5.19: Eficiência de remoção de DBO no decantador. ................................................ 121

Figura 5.20: Valores de DBO na entrada e saída do sistema global. ....................................121

Figura 5.21: Eficiência de remoção de DBO no sistema global........................................... 122

Figura 5.22: Concentrações de SST na entrada e saída do reator.......................................... 123

Figura 5.23: Concentrações de SST na entrada e saída do decantador. .................................. 124

Figura 5.24: Eficiência de remoção de SST no decantador................................................... 124

Figura 5.25: Concentrações de SST na entrada e saída do sistema......................................... 125

Figura 5.26: Eficiência de remoção de SST no sistema global. ........................................... 125

Figura 5.27: Variação do pH de entrada e saída no sistema................................................. 126

Figura 5.28: Valores de alcalinidade total na entrada e saída do sistema. ............................ 127 
Figura 5.29: Relação entre AI e AP nas amostras de entrada e saída do sistema................... 128

Figura 5.30: Relação AGV/Alcalinidade no sistema piloto. ............................................... 128

Figura 5.31: Perfil de sólidos suspensos no reator com 0 dias de operação, após inoculação.

Figura 5.32: Perfil de sólidos suspensos no reator 6 dias após a inoculação, sem alimentação.

Figura 5.33: Perfil de sólidos suspenso no reator com 10 dias de operação, após a inoculação.

Figura 5.34: Perfil de sólidos suspensos no reator com 33 dias de operação, após a inoculação.

Figura 5.35: Perfil de sólidos suspensos no reator com 03 dias de operação, após o $2^{\circ}$ inóculo.

Figura 5.36: Perfil de sólidos suspensos no reator com 19 dias após a segunda inoculação. 133

Figura 5.37: Perfil de sólidos suspensos no reator 29 dias após o segundo inóculo. .............. 134

Figura 5.38: Perfil de sólidos suspensos no reator 26 dias após o terceiro inóculo. ............... 135

Figura 5.39: Concentração de sólidos no lodo recirculado do decantador para o reator........ 136

Figura 5.40: Perfil de sólidos suspensos 26 dias após a última inoculação............................ 136

Figura 5.41:Perfil de sólidos suspensos 33 dias após o quinto inóculo................................ 137

Figura 5.42: Perfil de sólidos suspensos 40 dias após o último inóculo. ............................... 137

Figura 5.43: Perfil de sólidos 81 dias após o início da segunda etapa de operação (228 dias de

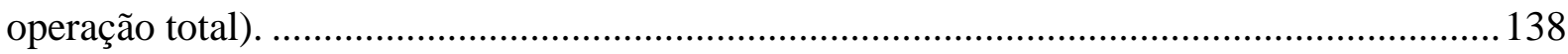

Figura 5.44: Perfil de sólidos para sistema operando com TDH de 8 horas. ........................... 139

Figura 5.45: Perfil de sólidos para o $246^{\circ}$ dia de operação do sistema. ................................. 140

Figura 5.46: Variação na concentração de sólidos suspensos junto ao fundo do reator......... 141

Figura 5.47: Variação da concentração de sólidos suspensos para 2,0 m de altura. .............. 142

Figura 5.48: Perfil de sólidos de um reator UASB tradicional (adaptado de Agricultural

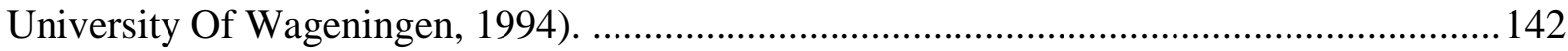

Figura 5.49: Valores diários da temperatura ambiente média. ............................................ 143

Figura 5.50: Valores de DQO na entrada e saída do filtro de areia...................................... 145

Figura 5.51: Eficiência de remoção de DQO no filtro de areia.............................................. 145

Figura 5.52:Concentração de SST para entrada e saída do filtro de areia.............................. 146

Figura 5.53: Eficiência de remoção de sólidos suspensos totais no sistema de filtração....... 146

Figura 5.54: Valores de turbidez na entrada e saída do filtro de areia. ................................. 147

Figura 5.55: Eficiência de remoção de turbidez no pós-tratamento por filtro de areia. ......... 147

Figura 5.56: Perda de carga medida ao longo do leito de filtração. ...................................... 148 
Página intencionalmente deixada em branco. 


\section{LISTA DE TABELAS}

Tabela 3.1: Sistemas de tratamento anaeróbio instalados na Holanda até 2007 (Van Lier,

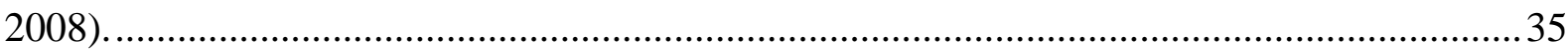

Tabela 3.2: Alguns parâmetros construtivos de reatores UASB tratando esgoto sanitário...... 38

Tabela 3.3: Desempenho de alguns reatores UASB tratando esgoto sanitário, ....................... 39

Tabela 3.4: Custos de implantação do reator UASB ............................................................. 41

Tabela 3.5: Alguns critérios para dimensionamento de reatores UASB alimentados com esgoto sanitário.

Tabela 3.6: Pós-tratamento por filtro de areia rápido no Kuwait (Hamoda e Al-Ghusain, 2004).

Tabela 4.1: Dimensões dos bocais utilizados nos dois reatores experimentais........................ 74

Tabela 4.2: Dimensionamento do reator utilizado na fase 2 da pesquisa............................... 76

Tabela 4.2: Dimensionamento do reator utilizado na fase 2 da pesquisa............................... 81

Tabela 4.3: Condições operacionais do decantador de alta taxa. .......................................... 85

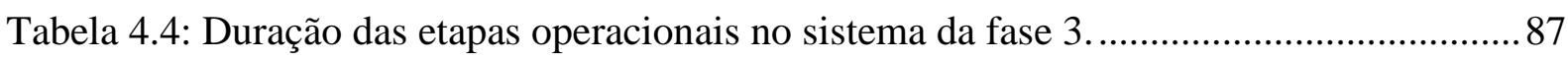

Tabela 4.5: Condições operacionais para o sistema anaeróbio. .............................................. 88

Tabela 4.6: Análises físico-químicas realizadas nas amostras. .............................................95

Tabela 4.7: Ensaio granulométrico da areia componente do meio filtrante. ............................96

Tabela 4.8: Características da camada suporte do filtro........................................................98

Tabela 4.9: Posicionamento dos piezômetros, em relação ao fundo do filtro, para aferição da

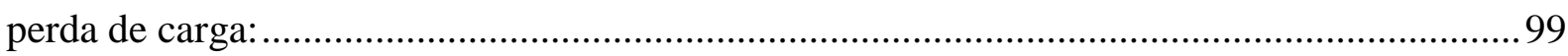

Tabela 5.1: Desempenho dos reatores de bancada tratando esgoto sanitário......................... 102

Tabela 5.2: Resultado dos modelos uniparamétricos para o escoamento do reator operando

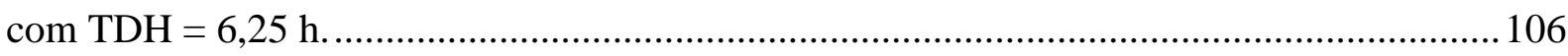

Tabela 5.3: Comparação do resultado dos modelos uniparamétricos para diversos

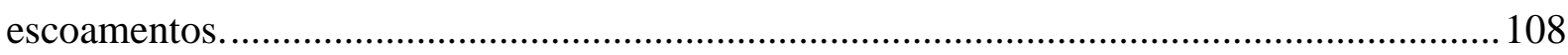

Tabela 5.4: Concentração de metais no lodo usado como inóculo........................................ 109

Tabela 5.5: Concentração de sólidos das amostras de lodo anaeróbio adicionado ao reator na

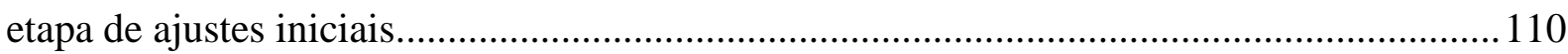

Tabela 5.6: Remoção de DQO por unidade e por etapa. ......................................................112

Tabela 5.7: Remoção de DQO de amostra filtrada por unidade e por etapa. ..........................115

Tabela 5.8: Remoção de DBO por unidade e por etapa. ...................................................... 119

Tabela 5.9: Remoção de SST por unidade e por etapa......................................................... 123

Tabela 5.10: Resumo dos valores médios das variáveis de monitoramento obtidas com o sistema operando com $\mathrm{TDH}=12$ horas.

Tabela 5.11: Resultados de DQO filtrada, $\mathrm{S}^{2-}, \mathrm{PO}_{4}{ }^{3-}, \mathrm{pH}$, Alcalinidade e AGV/Alcalinidade para $\mathrm{TDH}=12$ horas e 228 dias de operação.

Tabela 5.12: Resultados de DQO filtrada, $\mathrm{S}^{2-}, \mathrm{PO}_{4}{ }^{3-}, \mathrm{pH}$, Alcalinidade e AGV/Alcalinidade para TDH $=8$ horas e 236 dias de operação. 140

Tabela 5.13: Resultados de DQO filtrada, $\mathrm{S}^{2-}, \mathrm{PO}_{4}{ }^{3-}, \mathrm{pH}$, Alcalinidade e AGV/Alcalinidade

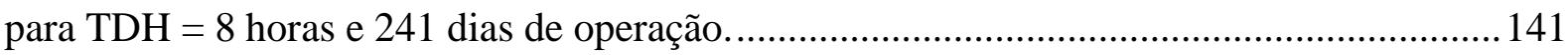

Tabela 5.14: Resultados dos ensaios de AME................................................................... 144 
Tabela 5.15: Desempenho, durante uma carreira, do filtro de areia como pós-tratamento ao efluente do sistema anaeróbio de manta de lodo.

Tabela 5.16: Comparação dos dados de DQO e SST entre o sistema experimental e reator UASB experimental da EESC/USP.

Tabela 5.17: Comparação dos dados de DQO e SST entre o sistema experimental e reatores

UASB escala plena relatados no item 3.2.3. 


\section{LISTA DE ABREVIATURAS E SIGLAS}

ABR - Anaerobic Baffled Reactor

ABNT - Associação Brasileira de Normas Técnicas

afl - Afluente

AGV - Ácidos Graxos Voláteis

$\mathrm{AI}$ - Alcalinidade Intermediária $\left(\mathrm{mgCaCO}_{3} . \mathrm{I}^{-1}\right)$

AME - Atividade Metanogênica Específica (mg DQO rem $\cdot \mathrm{g} \mathrm{SSV}^{-1}$ )

AP - Alcalinidade Parcial $\left(\mathrm{mgCaCO}_{3} .1^{-1}\right)$

APHA - American Public Health Association

AWWA - American Water Works Association

BCC - Bocal Cônico Convegente

BCD - Bocal Cônico Divergente

CBL - Calculator Based Laboratory

CETESB - Companhia de Tecnologia de Saneamento Ambiental

COV - Carga Orgânica Volumétrica $\left(\mathrm{kg} \cdot \mathrm{m}^{-3} \cdot \mathrm{dia}^{-1}\right)$

DBO - Demanda Bioquímica de Oxigênio (mg. $1^{-1}$ )

DQO - Demanda Química de Oxigênio (mg. $\left.\mathrm{l}^{-1}\right)$

DQO rem - Demanda Química de Oxigênio Removida (mg.1 ${ }^{-1}$ )

DTR - Distribuição do Tempo de Residência

EESC - Escola de Engenharia de São Carlos

efl - Efluente

EGSB - Expanded Granular Sludge Blanket

EPA - United States Environmental Protection Agency

ETE - Estação de Tratamento de Esgoto

Ltda - Limitada

NA - Nível d'água

NBR - Norma Brasileira

NTU - Unidade Nefelométrica de Turbidez

OMS - Organização Mundial da Saúde

rem - Remoção

rpm - Rotações por Minuto

SANASA - Sociedade de Abastecimento de Água e Saneamento S/A.

SRT - Tempo de Retenção Celular (dia) 
SSF - Sólidos Suspensos Fixos (mg. 1 $^{-1}$ )

SST - Sólidos Suspensos Totais (mg. $1^{-1}$ )

SSV - Sólidos Suspensos Voláteis (mg. ${ }^{-1}$ )

ST - Sólidos Totais (mg. $\mathrm{l}^{-1}$ )

STF - Sólidos Totais Fixos (mg. $\left.1^{-1}\right)$

STV - Sólidos Totais Voláteis (mg. $1^{-1}$ )

$\mathrm{T}$ - Ponto de Amostragem a 5,2 m do Fundo do Reator

TAS - Taxa de Aplicação Superficial

TDH - Tempo de Detenção Hidráulica (hora)

UASB - Upflow Anaerobic Sludge Blanket

USP - Universidade de São Paulo

WEF - Water Environment Federation 


\section{LISTA DE SÍMBOLOS}

$A b$ : Área da Seção Contraída do Bocal $\left(\mathrm{m}^{2}\right)$

$A L:$ Alcance Lateral do Jato (m)

$\mathrm{CaCO}_{3}$ : Carbonato de Cálcio (mg..$^{-1}$ )

CC: Coeficiente de Contração

Cd: Cádmio (mg.l $\left.{ }^{-1}\right)$

CD: Coeficiente de Descarga

Cn: Coeficiente de Não-uniformidade do Meio Filtrante

$\mathrm{CH}_{4}$ : Metano

$\mathrm{CO}_{2}$ : Dióxido de Carbono

Cr: Cromo (mg. $\left.1^{-1}\right)$

CV: Coeficiente de Correção de Velocidade

$\mathrm{Cu}$ : Cobre (mg..$\left.^{-1}\right)$

$D b$ : Diâmetro da Seção Contraída do Bocal $\left(\mathrm{m}^{2}\right)$

$D c$ : Diâmetro do Bocal na Saída do Jato (m)

D10: Diâmetro Efetivo do Meio Filtrante - Correspondente a 90\% dos Grãos Passantes Acumulados no Ensaio Granulométrico (mm)

D60: Diâmetro Correspondente a 40\% dos Grãos Passantes no Ensaio Granulométrico (mm)

Fe: Ferro (mg. $\left.1^{-1}\right)$

$g$ : Aceleração da Gravidade $\left(\mathrm{m} \cdot \mathrm{s}^{-2}\right)$

$G$ : Gradiente de Velocidade $\left(\mathrm{s}^{-1}\right)$

$h$ : Altura Manométrica (mca)

$h f$ : Perda de Carga (mca)

$h_{\text {piezômetro : Carga Manométrica Aplicada no Bocal (mca) }}$

Hac: Ácido Acético

$\mathrm{H}_{2} \mathrm{~S}$ : Sulfeto de Hidrogênio ou Gás Sulfídrico (mg. $\mathrm{l}^{-1}$ )

kgf: Kilograma Força

$\mathrm{Ki}$ : Constante de Inibição

kWh: Kilowatt Hora

L: Comprimento do Bocal (m)

mca: Metros de Coluna D’água

mEq: Miliequivalente 
Mn: Manganês (mg..$\left.^{-1}\right)$

N: Nitrogênio

$N$ : Newton

$\mathrm{NaCl}$ : Cloreto de Sódio (mg. $1^{-1}$ )

$\mathrm{NaOH}$ : Hidróxido de Sódio

Ni: Níquel (mg. $\left.1^{-1}\right)$

NTK: Nitrogênio Total Kjeldahl (mg. $\left.\mathrm{l}^{-1}\right)$

$\mathrm{N}$-amon: Nitrogênio Amoniacal (mg. $\mathrm{l}^{-1}$ )

$\mathrm{O}_{2}$ : Oxigênio

P0 - Ponto de Amostragem do Fundo do Reator

P1 - Ponto de Amostragem a 2,0 m do Fundo do Reator

P2 - Ponto de Amostragem a 3,4 m do Fundo do Reator

P3 - Ponto de Amostragem a 4,2 m do Fundo do Reator

$\mathrm{Pb}$ : Chumbo (mg. $\left.\mathrm{l}^{-1}\right)$

pH: Potencial Hidrogeniônico

$\mathrm{PO}_{4}{ }^{3-}$ : Fosfato $\left(\mathrm{mg} .1^{-1}\right)$

Pot $=$ Potência Hidráulica $\left(\mathrm{kgf} . \mathrm{m} . \mathrm{s}^{-1}\right)$

Pt-Co - Unidade de Cor

$Q: \operatorname{Vazão}\left(\mathrm{m}^{3} \cdot \mathrm{s}^{-1}\right)$

$\mathrm{S}^{2-}:$ Sulfeto $\left(\mathrm{mg} . \mathrm{l}^{-1}\right)$

$\mathrm{SO}_{4}{ }^{-2}:$ Sulfato $\left(\mathrm{mg} . \mathrm{l}^{-1}\right)$

Vbocal: Velocidade na Seção contraída do bocal (m.s $\left.\mathrm{s}^{-1}\right)$

$V j$ : Velocidade do Jato na Saída do Bocal $\left(\mathrm{m} . \mathrm{s}^{-1}\right)$

$V \max$ : Velocidade no centro do jato $\left(\mathrm{m} . \mathrm{s}^{-1}\right)$

Vol: Volume do Reator $\left(\mathrm{m}^{3}\right)$

$V z$ : Velocidade do jato no ponto $\mathrm{z}\left(\mathrm{m} \cdot \mathrm{s}^{-1}\right)$

W: Watt

Zn: Zinco (mg..$\left.^{-1}\right)$

$Y:$ Peso Específico $\left(\mathrm{N} . \mathrm{m}^{-3}\right)$

Z: Alcance Máximo do Jato (m)

$\mu$ : Viscosidade Dinâmica (N.s.m $\left.{ }^{-2}\right)$

$\boldsymbol{\theta}$ : Ângulo de Convergência ou Divergência do Bocal $\left({ }^{\circ}\right)$

${ }^{\circ} \mathrm{C}$ : Graus Celsius 


\section{SUMÁRIO}

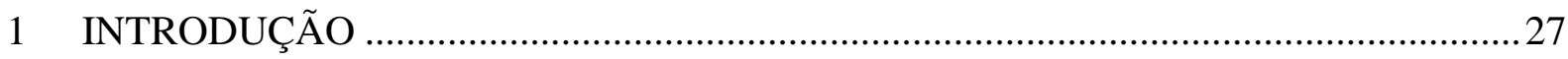

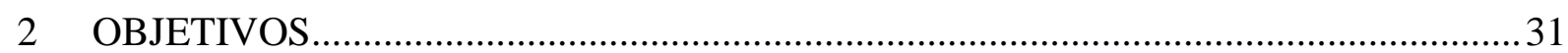

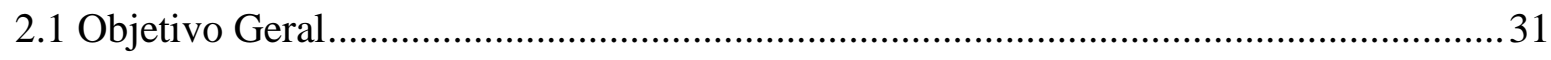

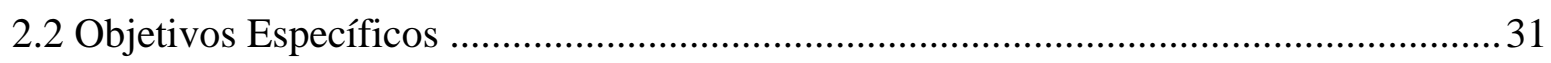

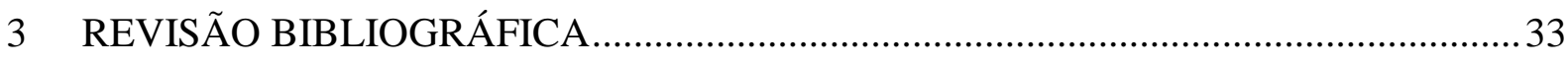

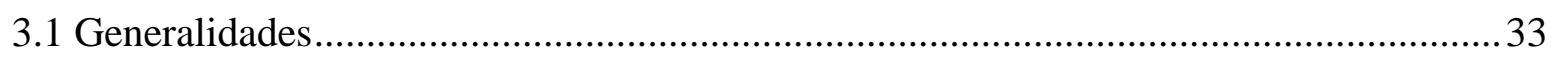

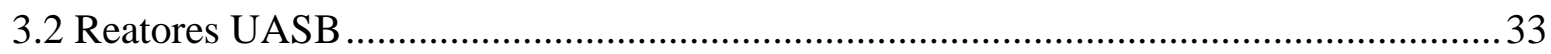

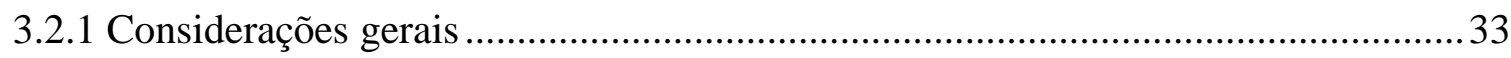

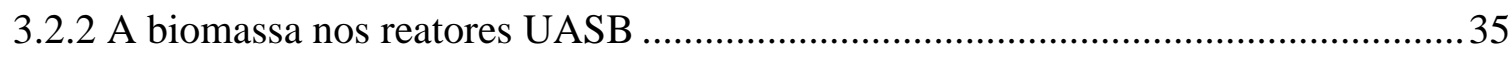

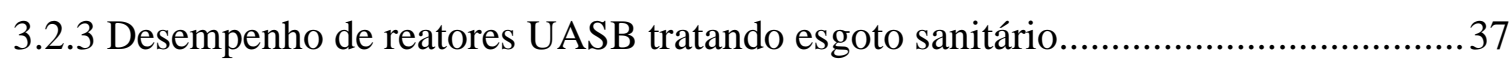

3.2.4 Principais problemas apresentados pelos reatores UASB .................................... 44

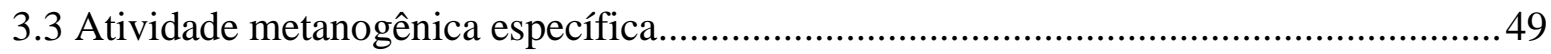

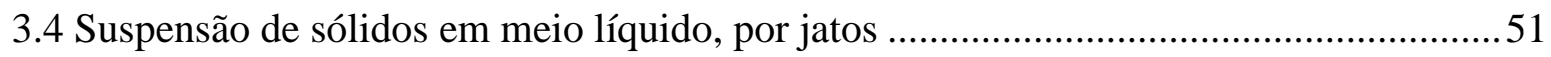

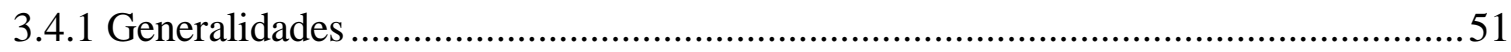

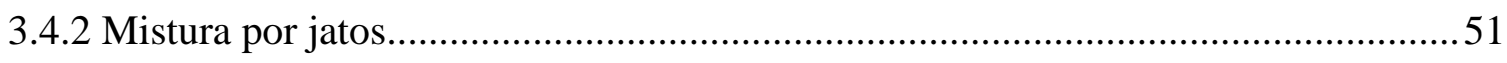

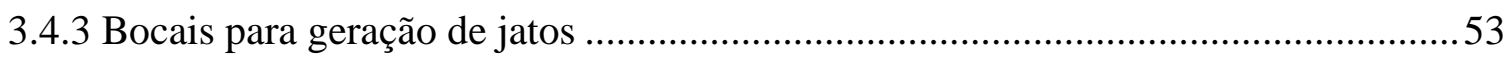

3.4.4 Tanques com conteúdo misturado por jatos ....................................................... 56

3.4.5 Efeito do ângulo de incidência do bocal ...............................................................58

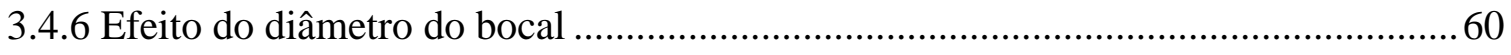

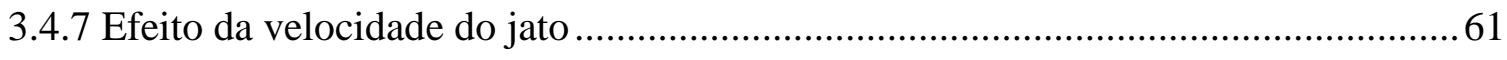

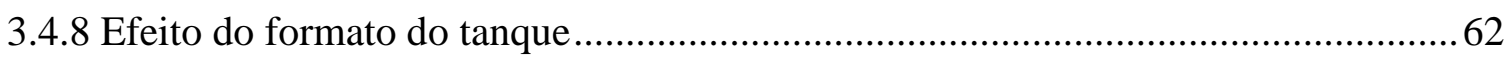

3.4.9 Comentários gerais sobre agitação por meio de jatos promovidos por bocais......... 62

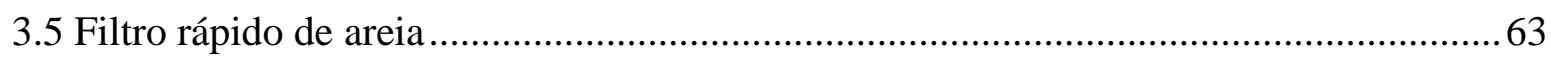

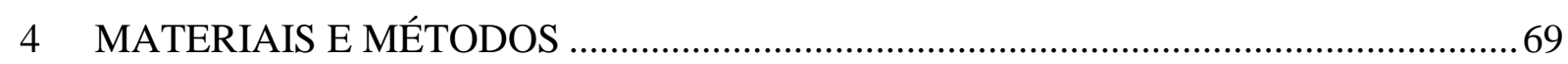

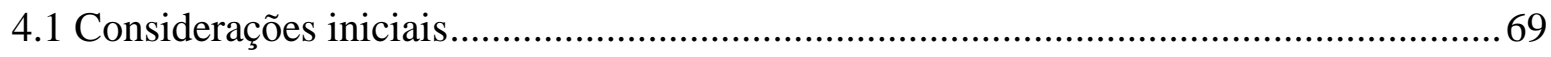

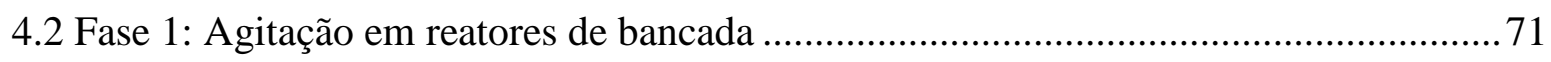

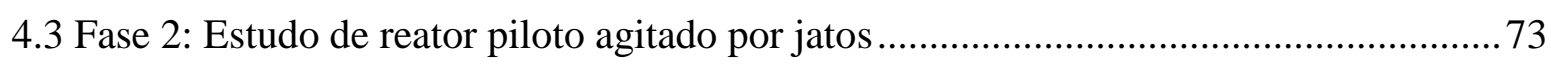

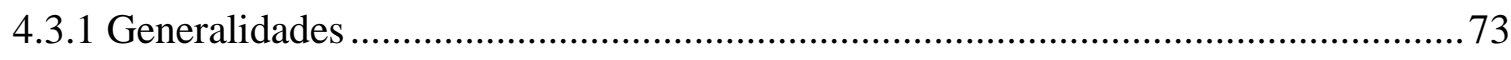

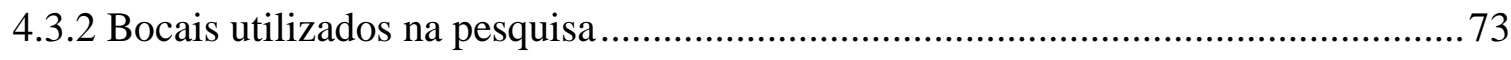

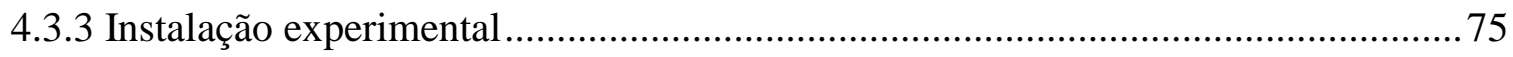




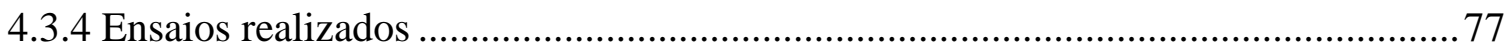

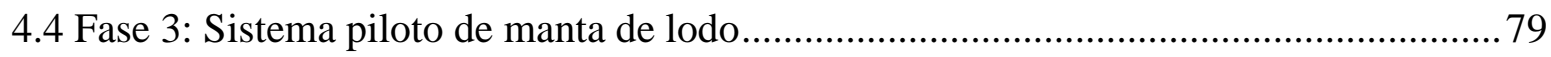

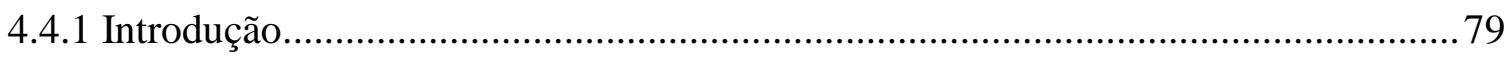

4.4.2 Descrição geral do sistema experimental (reator anaeróbio + decantador) .............. 80

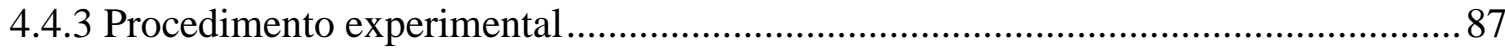

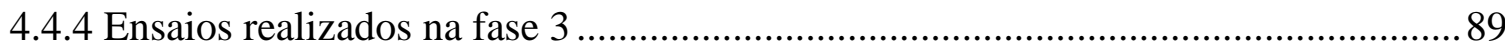

4.4.5 Instalação experimental para pós-tratamento do efluente (filtro rápido de areia)....96

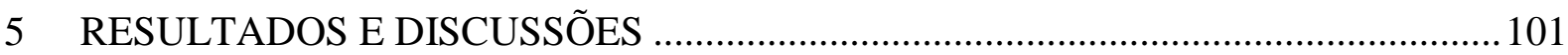

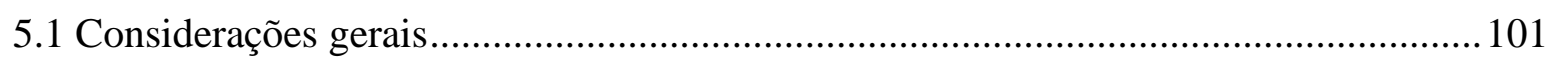

5.2 Fase 1: Agitação em reatores de bancada ................................................................ 101

5.3 Fase 2: Estudo de reator piloto agitado por jatos ....................................................... 103

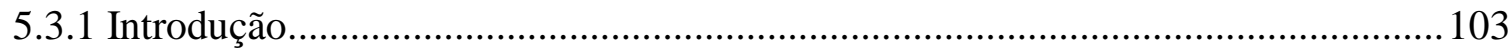

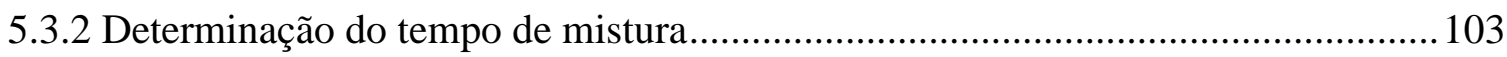

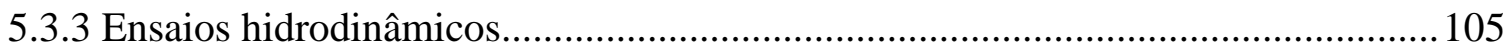

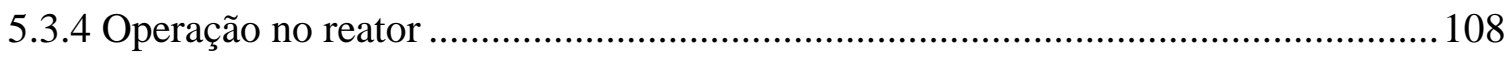

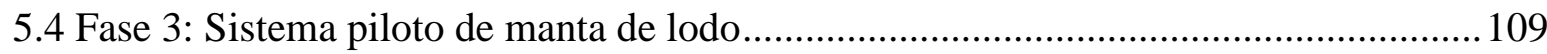

5.4.1 Caracterização do lodo utilizado como inóculo ....................................................... 109

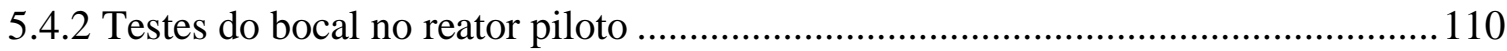

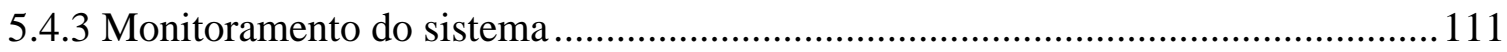

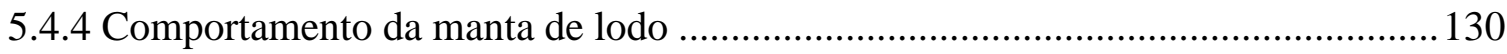

5.4.6 Pós-tratamento do efluente do sistema - filtro rápido de areia.............................. 144

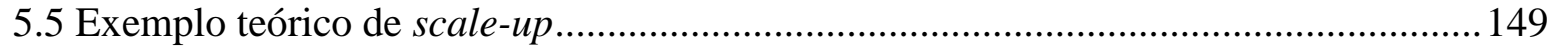

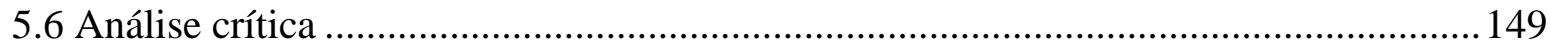

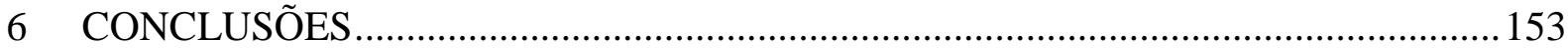

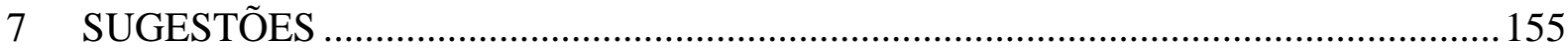

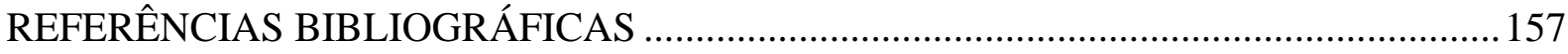




\section{INTRODUÇÃO}

O tratamento de águas residuárias, tanto doméstica como industrial, pode ser realizado mediante diversas opções de sistemas e unidades de tratamento. A escolha por uma delas é baseada na análise de diversos fatores, por exemplo: a característica do afluente e do efluente desejado, o recurso disponível para investimento, os custos operacionais do sistema, as características ambientais da localidade, entre outros.

$\mathrm{Na}$ vasta gama de possibilidades, a opção por tratamento biológico (quando viável tecnicamente), é usualmente vantajosa em comparação aos tratamentos físico-químicos, pois são mais econômicos e geram menos resíduos tóxicos (REYES-ÁVILA et al, 2004).

Com a proposição da concepção do Upflow Anaerobic Sludge Blanket Reactor (UASB) em Lettinga (1980), houve grande evolução no que concerne à área demandada, aos custos de instalação, operação e disposição final do lodo, comparando-se com os reatores aeróbios.

No entanto, após essa inovação, pouco se evoluiu no projeto dessa concepção de reator. Isso tem gerado incertezas acerca da eficiência máxima possível desse tipo de unidade de tratamento. Contudo, destaca-se aqui, que um reator anaeróbio não substituiu o sistema de lodos ativados, pois sua eficiência para esgoto sanitário varia, geralmente na faixa de 60 a $75 \%$ (em termos de remoção de demanda química de oxigênio - DQO).

Miki (2010), em seu trabalho intitulado "Dilemas do UASB", relata alguns problemas operacionais desse tipo de reator. Dentre os diversos problemas abordados, os que mais chamam atenção são aqueles referentes à alimentação do reator, captação do gás e remoção de sólidos suspensos do efluente.

Em relação à alimentação, o grande problema é o complexo sistema hidráulico que deve ser implantado para que haja um ponto de entrada a cada pequena área de fundo de reator $(1,0$ a 4,0 $\mathrm{m}^{2}$ ). Tal sistema, além de ser oneroso, sofre com problemas de entupimentos, menos recorrente em casos em que existe apenas uma tubulação de entrada para cada ponto de alimentação; e, se o problema não for detectado, o efluente não se distribui de forma uniforme no reator, o que gera caminhos preferenciais de escoamento e interfere na eficiência do tratamento.

Quanto aos coletores de gás e ao sistema de remoção de sólidos suspensos do efluente, esses podem não funcionar adequadamente devido ao acúmulo de escuma e materiais flutuantes. Com entupimentos, mesmo que parcialmente, nas canaletas de coleta do efluente, 
haverá sobrecarga na parcela que está em condições normais de operação. Desse modo o fluxo interno do reator poderá sofrer alteração e formar-se caminhos preferenciais.

Já no separador trifásico esse acúmulo de escuma e de sólidos pode, em alguns casos, entupir os coletores de gases, o que ocasiona o aumento do arraste de gases junto ao efluente e prejudica a sedimentação dos sólidos. Em casos extremos podem ocorrer danos nos componentes desses coletores e até sua ruptura (MIKI, 2010).

Sobre os digestores anaeróbios, O'flaherty et al (2006) relataram que os projetos muitas vezes resultam em reatores superdimensionados ou de tratamento instável. Segundo os autores essas imperfeições em projetos são recorrentes, pois os reatores são idealizados e executados sem conhecimento prático abrangente dos aspectos hidráulicos e biológicos de seu interior, apesar de existirem muitos estudos sobre os temas.

Em estudo realizado por Teixeira et al (2009) é abordado outro problema dos reatores UASB, que trata do teor de sólidos suspensos totais (SST) presentes no efluente do tratamento. Apesar de possuir parcela biodegradável, a matéria orgânica particulada muitas vezes é arrastada no efluente do reator em tempo menor que o tempo de detenção hidráulica de projeto, não havendo assim a degradação desejável desses compostos. Esse problema de perda de biomassa na saída de reatores UASB ocorre tanto por velocidades ascensionais elevadas e correntes preferenciais quanto pela alta produção de gás no reator.

Nas conclusões de Miki (2010) é sugerida a necessidade de aprimoramento dos projetos de reatores UASB. Ele endossa o quão necessário são os projetos relacionados com novas concepções de configuração do UASB ou de reatores anaeróbios em geral, a fim de minimizar os problemas existentes atualmente.

Ante ao exposto, em busca de melhorias na concepção e operação, nesta pesquisa, foram implementadas mudanças drásticas na configuração do reator UASB tradicional. Tais alterações, que atingem desde a alimentação do reator até a remoção de sólidos suspensos no efluente, foram motivadas para buscar uma configuração, que combina diversas tecnologias consolidadas na tentativa de: reduzir a formação de caminhos preferenciais; reter grande quantidade de lodo biologicamente ativo; e que seja de construção, operação e manutenção simples.

$\mathrm{Na}$ presente pesquisa foi utilizada na alimentação do reator um sistema que proporcionou grande mistura entre o esgoto sanitário afluente e a biomassa (distinta à mistura proporcionada somente pela gaseificação nos reatores UASB e pelo sistema de alimentação tradicional). 
$\mathrm{Na}$ nova concepção, o afluente foi inicialmente destinado a pequeno reservatório elevado, visando obter energia potencial para, posteriormente promover a mistura desejada por energia cinética (a ser dissipada pelos jatos no reator). Ao atingir o volume desejado o afluente deixa o reservatório em intervalos regulares e entra no reator através de bocais projetados para a devida agitação no reator, em pulsos consecutivos.

A coleta do efluente do reator era realizada em dispositivo afogado $(30 \mathrm{~cm}$ abaixo do nível d'água) para possibilitar que a escuma se concentrasse na interface água-biogás. Essa interface é também responsável pela liberação dos gases - pois os tradicionais separadores trifásicos foram removidos nesse projeto.

Após as calhas afogadas, o efluente é conduzido a uma unidade distinta da câmara de digestão, onde foi implantado decantador de alta taxa para retenção de sólidos suspensos.

Além disso, foi proposto pós-tratamento ao efluente desse sistema. Esse tratamento complementar foi composto por sistema de filtração utilizando filtro descendente com leito de areia de granulometria média. 
Página intencionalmente deixada em branco. 


\section{OBJETIVOS}

\subsection{Objetivo Geral}

O principal objetivo deste trabalho foi a concepção e o estudo de um novo sistema anaeróbio de manta de lodo para tratamento de esgoto sanitário, com mistura proporcionada por jatos provenientes de bocais, constituído de zonas de reação e de remoção de sólidos suspensos, independentes. Também tem-se como objetivo a comprovação de que decantadores de alta taxa se prestam à remoção de sólidos suspensos do efluente, em substituição ao separador trifásico.

\subsection{Objetivos Específicos}

- Estudar o uso de bocais para gerar mistura em reatores anaeróbios de manta de lodo.

- Testar a eficiência de remoção dos sólidos suspensos no efluente em decantador de alta taxa.

- Avaliar a eficiência de remoção de sólidos em suspensão e matéria orgânica no reator e em sistema de pós-tratamento por filtração rápida. 
Página intencionalmente deixada em branco. 


\section{REVISÃO BIBLIOGRÁFICA}

\subsection{Generalidades}

Este levantamento bibliográfico não visa abordar aspectos gerais sobre tratamento anaeróbio de esgotos, tema já amplamente discutido em outros trabalhos. As principais informações aqui contidas são, portanto, apenas aquelas essenciais e relacionadas com o embasamento conceitual e prático, da pesquisa objeto desta tese.

A concepção de reator proposta é distinta e inovadora em relação à concepção utilizada em reatores anaeróbios de manta de lodo. Neste trabalho busca-se simplificar a configuração tradicional desse reator, e assim reduzir os problemas operacionais e custos com a execução. Pensou-se em desenvolver um reator anaeróbio provido de poucos pontos de entrada e com sistema de agitação para garantir a manutenção da manta de lodo, e com setores distintos para as reações biológicas e para a separação dos sólidos suspensos arrastados no efluente (por decantador de alta taxa).

Nesse contexto, esse levantamento bibliográfico enfoca apenas os temas pertinentes: problemas relacionados aos reatores UASB, conceitos e prática do uso de bocais e filtração rápida.

\subsection{Reatores UASB}

\subsubsection{Considerações gerais}

O reator anaeróbio de manta de lodo (Upflow Anaerobic Sludge Blanket - UASB) é uma unidade de tratamento de fluxo ascendente que utiliza o processo anaeróbio para degradação da matéria orgânica. Foi proposto inicialmente por Lettinga et al (1980) para tratamento de efluentes industriais com alta carga orgânica e em temperatura na faixa mesofílica. A Figura 3.1 apresenta esquema típico desse tipo de reator. 
Segundo van Haandel e Lettinga (1994), o aumento no preço da energia na década de 1970 foi um dos fatores responsáveis para o desenvolvimento do reator UASB; pois foi valorizada a busca por processos que pudessem substituir o tratamento aeróbio.

Devido ao seu sucesso no tratamento de efluentes industriais, já no início da década de 1980, o reator UASB passou a ser aplicado no tratamento de esgoto sanitário; sendo construída em Cali a primeira grande estação a utilizar essa tecnologia. Mesmo com esses avanços ainda havia grande divisão entre pesquisadores e projetistas devido a ideia de que essa tecnologia estava atrelada a maus odores e a dificuldades operacionais. Somente na década de 1990 essa rejeição diminuiu com o avanço de técnicas experimentais que possibilitaram maior entendimento da bioquímica do processo e com maior sofisticação de projetos implantados.

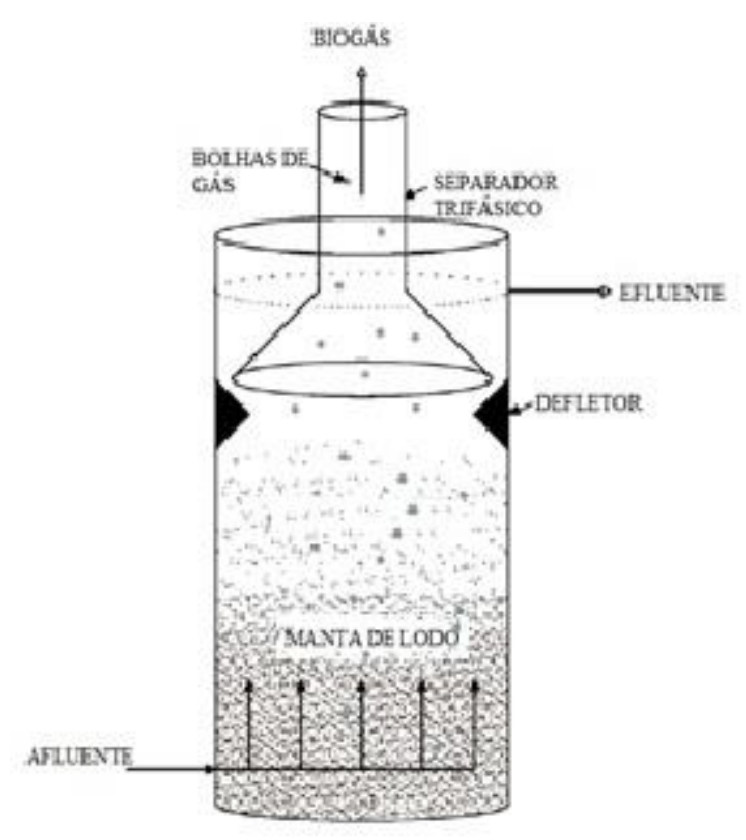

Figura 3.1: Esquema típico representando reator UASB, conforme concebido por Lettinga et al (1980).

A inclusão de parâmetros de projeto na revisão da NBR 12209/2011 (ABNT, 2011) veio consolidar a tecnologia UASB nas estações de tratamento de esgoto brasileiras. Mas ao contrário do esperado, nos últimos anos está crescendo o enfoque de trabalhos que apontam problemas relacionados a projetos e operação de reatores UASB.

A Tabela 3.1 (van LIER, 2008), ilustra como a implantação de reatores UASB está diminuindo nos últimos anos em relação a outras tecnologias de tratamento anaeróbio. Apesar de os números se referirem a trabalhos com efluente industrial, é notório que há espaço e necessidade para a inclusão de novas tecnologias e concepções de tratamento. 
Tabela 3.1: Sistemas de tratamento anaeróbio instalados na Holanda até 2007 (Van Lier, 2008).

\begin{tabular}{ccc}
\hline Unidade de tratamento & $\mathbf{1 9 8 1 - 2 0 0 7}$ & $\mathbf{2 0 0 2 - \mathbf { 2 0 0 7 }}$ \\
\hline Número total de unidades & 2266 & 610 \\
UASB & $50 \%$ & $34 \%$ \\
Expanded Granular Sludge Blanket (EGSB) & $12 \%$ & $22 \%$ \\
EGSB c/ Recirculação Interna & $15 \%$ & $33 \%$ \\
Filtro anaeróbio & $6 \%$ & $1 \%$ \\
Reator mistura completa & $7 \%$ & $4 \%$ \\
Lagoa anaeróbia & $4 \%$ & $1 \%$ \\
Reator de leito fluidizado & $2 \%$ & $2 \%$ \\
Reatores híbridos & $3 \%$ & $2 \%$ \\
Outros & $1 \%$ & $1 \%$ \\
\hline
\end{tabular}

\subsubsection{A biomassa nos reatores UASB}

Dentre os processos de tratamento, podem ser destacados alguns fatores fundamentais responsáveis por sua eficácia e, nas inovações proporcionadas pelo desenvolvimento dos reatores UASB, destaca-se o alto Tempo de Retenção de Lodo (SRT) no reator. A possibilidade de manter grande quantia de biomassa no reator, independentemente da taxa de aplicação hidráulica, permite ao reator UASB ser um sistema compacto e de boa eficiência de remoção de matéria orgânica.

Para a manutenção do tempo de retenção de sólidos satisfatório para o eficiente funcionamento dos reatores UASB é fundamental a presença de biomassa ativa, granulada e/ou floculenta. O fenômeno pelo qual as partículas discretas do lodo se aglomeram para formar grânulos bem definidos é conhecido como granulação. Kato et al $(1984,1997)$ observaram que o fenômeno de granulação é fundamental para o sucesso dos sistemas anaeróbios que são operados sem meio suporte para fixação da biomassa. Guiot et al (1986) relataram que a característica granular do lodo em reatores UASB se apresenta bem mais vantajosa quando comparada a característica floculenta de alguns lodos.

Para uma alta retenção da biomassa no compartimento de digestão, Hulshoff-Pol et al (1983) observaram que a velocidade de sedimentação e a atividade metanogênica específica devem ser elevadas (para uma alta eficiência de granulação).

Apesar de se valorizar a presença de grânulos, na quase totalidade de reatores UASB em operação, o consórcio de micro-organismos ocorre em flocos. Além disso, os trabalhos de 
Dolfing (1986) e Lin e Yang (1991) afirmam que para se obter bom desempenho nos reatores UASB a formação de lodo granular não é um pré-requisito.

Em virtude da grande variedade de micro-organismos em sua manta de lodo, os reatores UASB podem ser empregados no tratamento de diversos tipos de efluentes. Esses microorganismos se adaptam aos ambientes nos reatores, de modo a formar combinação adequada para haver a conversão de diversos compostos orgânicos em metano e outros subprodutos (HORI et al, 2006).

Essa estabilidade da biomassa pode ser atingida, inclusive, quando há mudança na forma de operação do mesmo reator. O estudo de Silva et al. (2007) indicou que a estabilidade da biomassa é uma resposta adaptativa dos micro-organismos e que poderá ser alcançada mesmo alterando-se o grau de mistura dos micro-organismos, já que não existe grande diferença entre as espécies existentes no leito e na manta de lodo dos reatores UASB tradicionais.

No entanto, essa mistura deve ser realizada com cautela. A explicação é dada por Sindall et al (2013), que realizaram estudo acerca da influência da agitação do lodo anaeróbio e a produção de biogás em digestores anaeróbios. Os autores concluíram que a produção de gás aumentou quando o gradiente de velocidade $(G)$ foi variado de 9,7 a $7,2 \mathrm{~s}^{-1}$; e diminuiu cerca de $50 \%$ quando o $G$ passou de 9,7 para $14,7 \mathrm{~s}^{-1}$.

Sobre a mistura de biomassa anaeróbia em digestores de lodo, Nahle (1991) observou que era necessária a aplicação de 2 a 5 Watt $(W)$ de potência para cada $\mathrm{m}^{3}$ de lodo a ser revolvido.

Em relação às concentrações de sólidos suspensos voláteis (SSV) junto ao fundo de reatores UASB, estas podem atingir de 40 a $100 \mathrm{gSSV} .1^{-1}$. Imediatamente acima do fundo, esses valores variam de 15 a 30 gSSV. $\mathrm{l}^{-1}$, porém essa concentração diminui drasticamente, geralmente a partir de cerca de 1,0 m do fundo do reator (AIYUK et al, 2006).

Um indicativo da capacidade de biodegrabilidade da biomassa é a relação entre sólidos suspensos voláteis e sólidos suspensos totais (SSV/SST), que é considerada ideal entre 0,70 e 0,85. Essa relação também serve de parâmetro para verificar o grau de estabilização da biomassa no período inicial (de adaptação) do lodo ao efluente. Durante este período a biomassa pode estar muito instável. Contudo, valores menores que 0,4 podem ser encontrados para SSV/SST (MAHMOUD, 2002). 


\subsubsection{Desempenho de reatores UASB tratando esgoto sanitário}

Ao longo dos últimos 35 anos, constatou-se que os reatores UASB oferecem muitos benefícios para as estações de tratamento de esgoto, visto que, esse reator pode substituir (conjuntamente) decantadores primários, adensadores e digestores de lodo, além de remover cerca de 60\% a 75\%, da Demanda Bioquímica de Oxigênio (DBO) presente no esgoto sanitário bruto.

Os principais fatores que influenciam na eficiência do UASB são: temperatura, configuração física do reator, composição do afluente, grau de mistura, $\mathrm{pH}$, carregamento orgânico volumétrico (COV), toxicidade do efluente, velocidade ascensional, tamanho e composição das partículas do lodo, atividade bacteriana, etc (LETTINGA E HULSHOFF POL, 1991).

Nas Tabelas 3.2 e 3.3 são apresentados, respectivamente, dados de projeto, de funcionamento e desempenho de reatores UASB para diversos cenários. Foram levantadas informações de algumas estações construídas em países de clima tropical, sobretudo de estações brasileiras.

Além dos dados de eficiência, os autores citados fizeram várias constatações que se apresentaram importantes para o desenvolvimento e consolidação do uso dos reatores UASB. As proposições mais pertinentes estão relatadas nos próximos parágrafos.

No estudo de Noyola (2004), foram levantados os dados de desempenho dos primeiros reatores UASB utilizados para tratar esgoto sanitário. Esses reatores foram construídos na Colômbia, no Brasil e na Índia entre os anos de 1983 e 1990. 
Tabela 3.2: Alguns parâmetros construtivos de reatores UASB tratando esgoto sanitário.

\begin{tabular}{|c|c|c|c|c|c|c|}
\hline Localidade - Estação & $\begin{array}{c}\text { Capacidade } \\
\left(\mathbf{m}^{3} \cdot \text { dia }^{-1}\right)\end{array}$ & $\begin{array}{l}\text { Número de } \\
\text { reatores }\end{array}$ & $\begin{array}{l}\text { Volume por } \\
\text { reator }\left(\mathbf{m}^{3}\right)\end{array}$ & TDH (h) & $\begin{array}{c}\text { Velocidade } \\
\text { ascensional }\left(\mathbf{m} \cdot \mathbf{h}^{-1}\right)\end{array}$ & Fonte \\
\hline Colômbia -Cali & - & 1 & 64 & 6 & $0,5-1,44$ & NOYOLA (2004) \\
\hline Brasil - CETESB & - & 1 & 120 & 6,1 & 1,4 & NOYOLA (2004) \\
\hline Brasil - Pedregal & - & 1 & 160 & 5,7 & $0,23-1,43$ & NOYOLA (2004) \\
\hline Colombia -Bucaramanga & - & 3 & 3300 & 5 & 0,79 & NOYOLA (2004) \\
\hline India - Kampur & - & 1 & 1200 & 6 & - & NOYOLA (2004) \\
\hline Brasil - 10 ETE no sudeste & 3.038 & - & - & $6-9$ & $0,5-0,7$ & OLIVEIRA E SPERLING (2011) \\
\hline Brasil - 20 ETE Fortaleza & - & - & - & 8,5 & - & SILVA et al (2013) \\
\hline Brasil A & 164.000 & 24 & 2286 & 8 & 0,57 & HEFFERNAN et al (2011) \\
\hline Brasil B & 90.000 & 16 & 2029 & 8 & 0,53 & HEFFERNAN et al (2011) \\
\hline Brasil C & 38.000 & 6 & 2029 & - & - & HEFFERNAN et al (2011) \\
\hline Índia - 16 ETE & - & - & - & $8,4-10,9$ & 0,5 & SATO et al (2006) \\
\hline Índia $A$ & 120.000 & 20 & 1960 & 7,8 & 0,62 & HEFFERNAN et al (2011) \\
\hline Índia B & 43.000 & 6 & 2304 & 7,7 & 0,62 & HEFFERNAN et al (2011) \\
\hline Índia C & 14.000 & 2 & 2413,67 & 8 & - & PANDEY (2014) \\
\hline Emirados Árabes & 49.000 & 8 & 2645 & 10,3 & 0,48 & HEFFERNAN et al (2011) \\
\hline
\end{tabular}


Tabela 3.3: Desempenho de alguns reatores UASB tratando esgoto sanitário,

\begin{tabular}{|c|c|c|c|c|c|c|c|c|c|c|}
\hline Localidade - Estação & $\begin{array}{c}\text { DQO } \\
\text { afl } \\
\left(\mathrm{mg.l}^{-1}\right)\end{array}$ & $\begin{array}{c}\text { DQO } \\
\text { efl } \\
\left(\mathrm{mg.l}^{-1}\right)\end{array}$ & $\begin{array}{c}\text { DQO } \\
\text { rem } \\
(\%)\end{array}$ & $\begin{array}{c}\text { DBO } \\
\text { afl } \\
\left(\mathrm{mg.l}^{-1}\right)\end{array}$ & $\begin{array}{c}\text { DBO } \\
\text { efl } \\
\left(\mathrm{mg.l}^{-1}\right)\end{array}$ & $\begin{array}{c}\text { DBO } \\
\text { rem } \\
(\%)\end{array}$ & $\begin{array}{l}\text { SST afl } \\
\left(\mathrm{mg.l}^{-1}\right)\end{array}$ & $\begin{array}{c}\text { SST efl } \\
\left(\mathrm{mg.l}^{-1}\right)\end{array}$ & $\begin{array}{l}\text { SST } \\
\text { rem } \\
(\%)\end{array}$ & Fonte \\
\hline Colômbia -Cali & 321 & 109 & 65 & 161 & 31 & 81 & 212 & 41 & 81 & NOYOLA (2004) \\
\hline Brasil - Pedregal & 695 & 273 & 61 & 471 & 146 & 69 & 472 & 276 & 42 & NOYOLA (2004) \\
\hline Colombia -Bucaramanga & 365 & 132 & 63 & 171 & 40 & 76 & 225 & 58 & 74 & NOYOLA (2004) \\
\hline $\begin{array}{l}\begin{array}{l}\text { Brasil - } \\
\text { sudeste }\end{array} \\
\text { ETE no }\end{array}$ & 715 & 251 & 59 & 371 & 98 & 72 & 289 & 85 & 67 & $\begin{array}{l}\text { OLIVEIRA E } \\
\text { SPERLING (2011) }\end{array}$ \\
\hline Brasil - 20 ETE Fortaleza & 818 & 338 & 59 & - & - & - & 399 & 213 & 47 & SILVA et al (2013) \\
\hline Brasil A & 440 & 178 & 60 & 267 & 78 & 71 & 236 & 120 & 49 & HEFFERNAN (2011) \\
\hline Brasil B & 549 & 182 & 67 & 233 & 77 & 71 & 262 & 79 & 70 & HEFFERNAN (2011) \\
\hline Índia B & 459 & 233 & 49 & 207 & 131 & 37 & 228 & 111 & 51 & HEFFERNAN (2011) \\
\hline Índia C & 405 & 202 & 50 & 144 & 60 & 52 & 400 & 150 & 62 & PANDEY (2014) \\
\hline Emirados Árabes & 697 & 337 & 52 & 268 & 130 & 51 & 252 & 40 & 84 & HEFFERNAN (2011) \\
\hline Média & 534 & 233 & 58 & 241 & 89 & 62 & 268 & 122 & 58 & - \\
\hline
\end{tabular}


Na Tabela 3.3 nota-se menor eficiência nas estações indianas em relação às demais estações levantadas. Segundo Heffernan et al (2011) um dos fatores prováveis por essa diferença é a qualificação dos operadores. Os autores expõem que nas estações brasileiras visitadas os operadores determinavam com frequência a altura de manta de lodo e controlavam o descarte desta, ao passo que nas estações indianas esse trabalho era negligenciado. Essa operação inadequada leva a altas concentrações de DQO no efluente devido à elevada concentração de SST.

Dos dez reatores UASB estudados por Oliveira e Sperling (2011), grande parcela de unidades apresentou desempenho abaixo do esperado. Em relação à DBO de saída, 30 \% dos reatores apresentaram valores acima de $100 \mathrm{mg} \cdot \mathrm{l}^{-1}$; no que concerne aos SST, $40 \%$ dos reatores

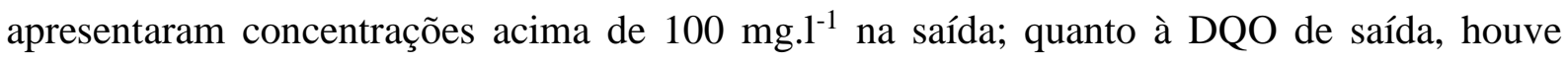
concentrações acima de 270 mg. $1^{-1}$ em $50 \%$ dos reatores UASB. Perante tais resultados os autores propõem que sejam buscadas melhorias no projeto e na operação dos UASB.

Apesar do desempenho não satisfatório, Oliveira e Sperling (2011) observaram que a taxa de carregamento orgânico volumétrico não foi fator que teve influência na remoção da DQO. Essa observação é contrária ao exposto por Lettinga et al (1993). No trabalho de Lettinga et al (1993) relatou-se que uma taxa de COV abaixo de $2 \mathrm{~kg} \cdot \mathrm{m}^{-3} \cdot \operatorname{dia}^{-1}$ afeta (diminui) a produção de biogás, deteriorando a agitação do reator, sendo necessário projetar o sistema de alimentação com entradas mais próximas umas das outras para compensar a baixa agitação.

No trabalho de Silva et al (2013) foi considerado relativamente baixo o desempenho dos reatores UASB. Das vinte unidades estudadas, doze reatores possuíam eficiência de remoção de DQO acima de $60 \%$; e oito reatores possuíam eficiência de remoção de SST superior a 60 $\%$. O desempenho insatisfatório foi atribuído às baixas vazões de entrada no período noturno. Quando a vazão fica muito baixa, a mistura no reator é afetada e formam-se bolsões de gases que ficam aprisionados na manta de lodo. Quando a vazão volta à normalidade esses bolsões se desprendem carreando grande parcela de sólidos. A influência negativa da flutuação de carga hidráulica no desempenho de reatores foi amplamente discutida por Leitão et al (2006).

No processo anaeróbio as bactérias redutoras de sulfato e as arqueas metanogênicas competem pelo mesmo substrato. Segundo Tchobanoglous et al (2004), os valores característicos de sulfato no esgoto variam de 20 a 50 mg. $\mathrm{l}^{-1}$. Em efluentes com grandes concentrações de sulfato, as bactérias redutoras de sulfato convertem o sulfato da forma orgânica para a forma inorgânica $\left(\mathrm{SO}_{4}{ }^{-2}\right)$ - e, posteriormente sulfeto $\left(\mathrm{H}_{2} \mathrm{~S}\right)$ - prejudicando a remoção de DQO. 
Segundo Hulshoff Pol et al (1998) e Souza (1986) é recomendável que a relação $\mathrm{DQO} / \mathrm{SO}_{4}{ }^{-2}$ seja superior a 10 . Caso contrário, ocorre aumento do odor e da corrosão, e diminuição na produção de biogás e na remoção de DQO.

No trabalho de Heffernan et al (2011) foram relatadas concentrações de sulfato no esgoto sanitário de $388 \mathrm{mg} . \mathrm{l}^{-1}$. Mahmoud et al (2002) observaram concentrações de sulfato até 900 mg. $1^{-1}$. O impacto negativo, nesses casos, na remoção da matéria orgânica, é bem elevado. Os autores indicam que esse deve ser um parâmetro sempre observado nas operações de reatores anaeróbios.

Em relação à presença de areia no esgoto sanitário, antes do tratamento preliminar, van Haandel e Lettinga (1994) observaram um volume característico de $75 \mathrm{ml}$ por $\mathrm{m}^{3}$ de esgoto. A remoção média nas caixas de areia observada por Heffernan et al (2011) foi de $77 \mathrm{ml}$ por $\mathrm{m}^{3}$ de esgoto. Porém uma das estações utilizava caixa de areia aerada, que apresentava introdução de ar de forma inadequada, resultando em remoção de apenas $8 \mathrm{ml}$ de areia por $\mathrm{m}^{3}$ de esgoto. À vista disso, nota-se a importância de se dispor de tratamento preliminar com funcionamento adequado. No exemplo da estação citada observa-se que o afluente tem $67 \mathrm{ml}$ de areia por $\mathrm{m}^{3}$ de esgoto, o que significaria um acúmulo de areia equivalente a $10 \%$ do volume de digestão de um reator UASB, no período de um ano.

No que diz respeito à manutenção dos reatores UASB, Heffernan et al (2011) observaram que na maioria das 10 estações de tratamento estudadas não havia nenhum programa de manutenção preventiva. Essa conduta é típica da grande maioria dos operadores das estações, que acreditam que o tratamento pode ocorrer sem manutenção alguma, ou, simplesmente ignoram esse cuidado. Khalil et al (2008) apurou que o custo anual de manutenção e operação do reator UASB é menor que $1 \%$ do capital de implantação, e 30\% inferior ao custo de manutenção e operação com os sistemas de lodos ativados (levantamento efetuado na Índia). Para exemplificar esse custo, na Tabela 3.4 são apresentados alguns levantamentos sobre o custo de implantação de reatores UASB.

Tabela 3.4: Custos de implantação do reator UASB

\begin{tabular}{ccc}
\hline Custo* $^{*}$ & Localidade & Fonte \\
\hline 300 U $\$ . m^{-3}$ & Brasil & VIEIRA E SOUZA (1986) \\
$181 \mathrm{U} \$ \$ . \mathrm{m}^{-3}$ & Colômbia & SCHELLINKHOUT E COLLAZOS (1992) \\
125 a $250 \mathrm{U} \$ \$ . \mathrm{m}^{-3}$ & Brasil & von SPERLING (1996) \\
\hline
\end{tabular}

*Observar datas de referência 
Todavia, para que esses custos de manutenção sejam baixos, é necessário que o projeto executivo e a escolha dos materiais empregados sejam realizados de forma criteriosa. Na Figura 3.2 é apresentada a corrosão nas paredes internas das canaletas de um reator UASB, após três anos de operação. Os custos para reforma e aplicação de novo revestimento foi estimado entre 15 e $20 \%$ do custo de implantação de toda a estação.

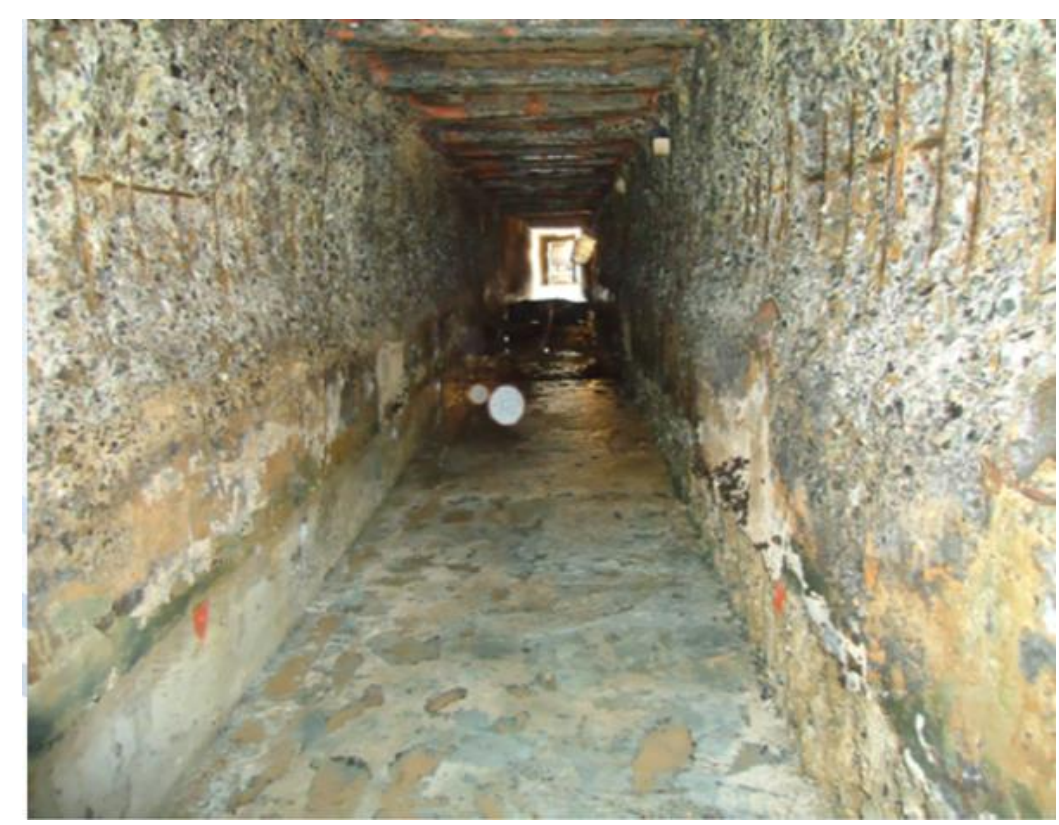

Figura 3.2: Corrosão em canaletas do efluente de um reator UASB (SANASA).

Ainda sobre manutenção de reatores UASB, Ramos et al (2010) realizaram investigação em 12 reatores. Os autores levantaram dados sobre o funcionamento do tratamento preliminar, e frequência de descarte de lodo e escuma. Os resultados apresentados nas Figuras 3.3; 3.4 e 3.5 demonstram que não é dada a devida importância às operações de manutenção. 


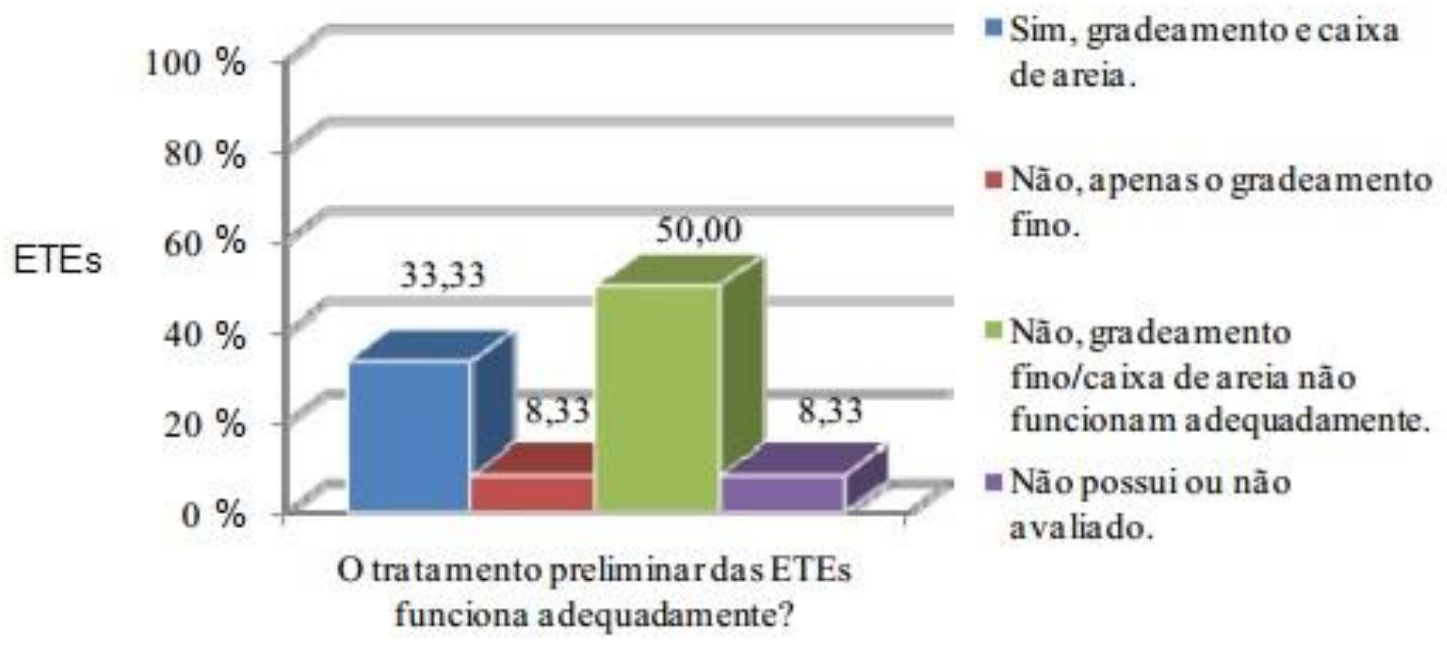

Figura 3.3: Avaliação da funcionalidade do tratamento preliminar ao UASB (adaptado de RAMOS et al, 2010)

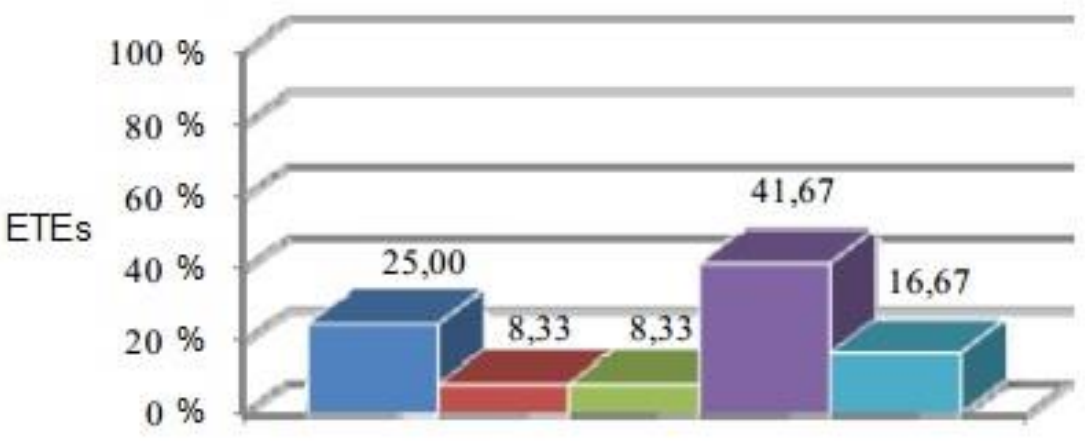

= Semanal.

" Quinzenal.

= Semestral.

=Outra.

"Não há ou não informado.

Figura 3.4: Frequência de descarte de lodo dos reatores UASB (RAMOS et al, 2010).

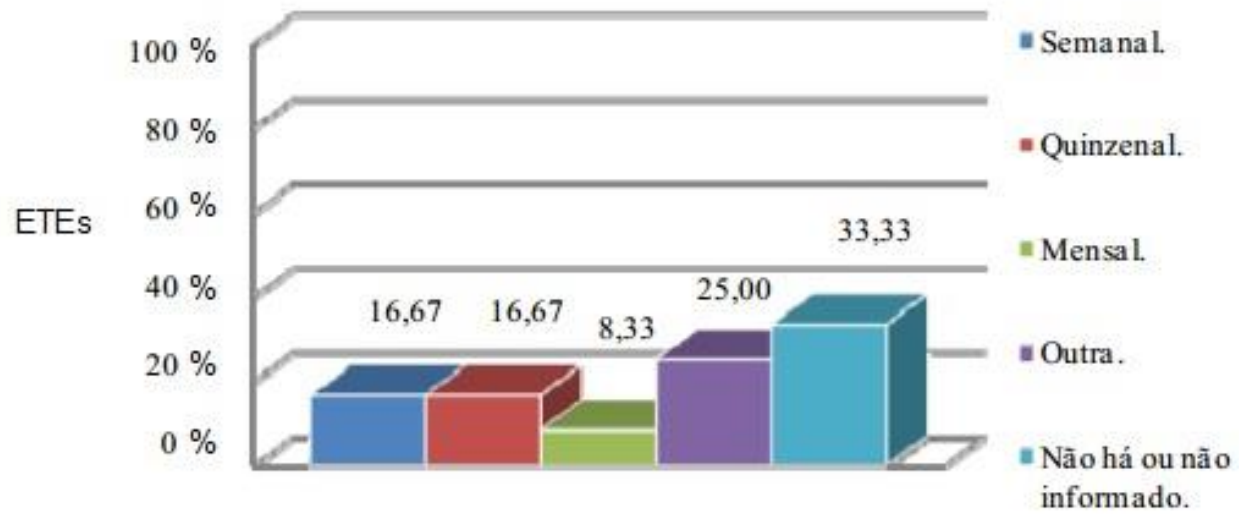

Figura 3.5: Frequência de remoção de escuma dos reatores (RAMOS et al, 2010). 
O desempenho dos reatores UASB também pode ser avaliado - e de modo mais econômico - através das simulações matemáticas. Para exemplificar como os modelos matemáticos têm gerado bons resultados, cita-se o trabalho de Elmitwalli (2013). O autor desenvolveu modelo empírico para representar a remoção físico-química dos sólidos suspensos em reatores UASB. Concluiu-se que para haver remoção adequada da DQO, o tempo de detenção hidráulica deveria ser maior ou igual a 4 horas e não há necessidade de ser maior que 12 horas. Esse resultado é o mesmo apresentado por reatores UASB na prática.

\subsubsection{Principais problemas apresentados pelos reatores $U A S B$}

Os estudos enfocados no item anterior, de maneira geral, conferem bons resultados acerca do desempenho do reator UASB em sua forma original. Contudo, os reatores UASB devem obedecer a certos preceitos de projeto, conforme constam em norma, artigos técnicos e resultados de pesquisas e, principalmente, na experiência da operação e manutenção reatores em operação; além disso, é obrigatória a previsão de dispositivos complexos de alimentação e de separação trifásica - o que eleva seu custo de maneira considerável.

$\mathrm{Na}$ Tabela 3.5 estão relacionados alguns desses preceitos de projeto conforme citados na literatura técnica. Para exemplificar como houve pouca alteração na forma de projetar os reatores UASB, Tchobanaglous et al (2004) - uma das referências mais respeitadas do mundo - utilizam-se dos mesmos parâmetros de projeto propostos por Lettinga e Hulshoff Pol (1991).

Alguns problemas relativos aos reatores UASB foram descritos no trabalho de Miki (2010), intitulado "Dilemas do UASB". Dentre os diversos problemas abordados, os que mais chamam atenção são aqueles relativos à complexidade do sistema de alimentação do reator, à captação do gás, limpeza dos separadores trifásicos e separação dos sólidos suspensos gerados.

Chernicharo e Stuetz (2008) apontaram os problemas dos reatores UASB, por setor. Na zona de reação foram relatados os problemas com acumulação de escuma e corrosão nos sistemas de alimentação e de separação trifásico. Quanto ao gás gerado foi relatada a emissão de odor, corrosão e toxicidade. No efluente do reator foram detectadas altas concentrações de carbono residual, nutrientes, patógenos, surfactantes, emissão de odores e arraste de significativa quantidade de metano. 
Tabela 3.5: Alguns critérios para dimensionamento de reatores UASB alimentados com esgoto sanitário.

\begin{tabular}{|c|c|c|c|c|c|c|}
\hline Fonte & $\begin{array}{c}\text { Temperatura } \\
\text { média }\left({ }^{\circ} \mathbf{C}\right)\end{array}$ & $\begin{array}{c}\text { TDH } \\
\text { médio(hora) }\end{array}$ & $\begin{array}{c}\text { Profundidade } \\
\text { útil (m) }\end{array}$ & $\begin{array}{c}\text { Velocidade } \\
\text { ascensional }\left(\mathrm{m}^{-h^{-1}}\right)\end{array}$ & 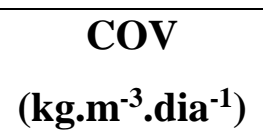 & $\begin{array}{l}\text { Área atendida por } \\
\text { ponto de entrada }\end{array}$ \\
\hline \multirow{4}{*}{ NBR 12209/2011 } & $>25$ & 6 & \multirow{4}{*}{4 a 6} & & \multirow{4}{*}{-} & \multirow{4}{*}{$\leq 3 \mathrm{~m}^{2}$} \\
\hline & 22 a 25 & 7 & & $\leq 0,7 \mathrm{p} / \mathrm{Q}$ média & & \\
\hline & 18 a 21 & 8 & & $\leq 1,2 \mathrm{p} /$ Qmáxima & & \\
\hline & 15 a 17 & 10 & & & & \\
\hline \multirow{3}{*}{$\begin{array}{c}\text { Tchobanaglous et al } \\
\text { (2004) }\end{array}$} & $>26$ & 6 a 8 & \multirow{3}{*}{3 a 5} & \multirow{3}{*}{0,8 a 1,0} & \multirow{3}{*}{$\begin{array}{l}1 \text { a } 2 \\
>3\end{array}$} & \multirow{3}{*}{$\begin{array}{l}1 \text { a } 2 \mathrm{~m}^{2} \\
2 \text { a } 5 \mathrm{~m}^{2}\end{array}$} \\
\hline & 22 a 26 & 7 a 9 & & & & \\
\hline & 16 a 19 & 10 a 14 & & & & \\
\hline $\begin{array}{c}\text { Calijuri e Cunha } \\
\qquad(2012)\end{array}$ & - & 6 a 10 & - & 0,5 a 0,7 & 4 a 8 & - \\
\hline \multirow{3}{*}{$\begin{array}{l}\text { Lettinga e Hulshoff } \\
\text { Pol (1991) }\end{array}$} & $>26$ & $<6$ & \multirow{3}{*}{-} & \multirow{3}{*}{-} & \multirow{3}{*}{$\begin{array}{l}1 \text { a } 2 \\
>3\end{array}$} & \multirow{3}{*}{$\begin{array}{l}1 \text { a } 2 \mathrm{~m}^{2} \\
2 \text { a } 5 \mathrm{~m}^{2}\end{array}$} \\
\hline & 22 a 26 & 7 a 9 & & & & \\
\hline & 16 a 19 & 10 a 14 & & & & \\
\hline
\end{tabular}


A escuma é responsável por problemas na captação de gás e do efluente líquido; sua formação geralmente se dá em presença de materiais surfactantes, e estes são usualmente encontrados no esgoto sanitário. Essa escuma se forma devido ao aprisionamento de bolhas de gás por uma película de líquido, motivados pelos agentes de superfície ativa. Assim, mesmo em concentração reduzida de surfactantes, os materiais de massa específica menor que a da água, como óleos, cabelos, borrachas, gorduras, graxa, que apresentam tendência natural de flutuar, podem se separar da biomassa e subir para a superfície do reator, gerando a escuma (GERARDI, 2003).

Segundo Souza (2006), em reatores que apresentam condições de mistura e temperatura adequadas, ocorrem processos naturais de decomposição da escuma; fatores que poderiam ser melhor explorados em projetos desse tipo de reator. O material flutuante contém, ainda, elevada concentração de matéria degradável. Em sistemas em que a remoção desse material pode ser efetuada poder-se-ia valorizar seu potencial energético.

Ainda que a escuma seja responsável por grande parte dos problemas apresentados pelos reatores UASB, o seu gerenciamento apropriado apresenta alguns benefícios. Garcia et al (2012) estudaram a capacidade de oxidação de sulfetos através de organismos presentes na escuma. Os testes foram realizados em dois reatores UASB, de volume 343 litros cada e operados com TDH de 5 e 7 horas. Foi verificado que a concentração de sulfeto sofreu redução de 76 a $97 \%$, antes e após a escuma.

Em relação ao arraste de sólidos em reatores tratando esgoto sanitário, Aiyuk et al (2006) afirmaram que o fator de maior influência no desempenho dos reatores UASB é a alta concentração de SST no efluente. Para inibir essas altas concentrações de SST os autores propõem medidas para o pré-tratamento e para o pós-tratamento. No pré-tratamento é recomendada a aplicação de cloreto férrico ou polieletrólito; enquanto no pós-tratamento orienta-se a integração, ao reator UASB, de unidades complementares simples para remoção de sólidos suspensos.

Outro aspecto negativo dos reatores UASB para tratamento de esgoto sanitário é a necessidade de grande volume ocupado por dispositivos de decantação e coleta de gases. Isso porque eles são usualmente construídos com alturas de 4,0 a 5,0 m. Porém a altura do compartimento de decantação pode chegar até pouco mais de 2,0 m. Isso significa que em quase $50 \%$ do volume do reator não há digestão expressiva da matéria orgânica (pode-se considerálo como "volume perdido"). 
$\mathrm{Na}$ prática, tem-se notado dificuldades de execução para se manter o ambiente hermético, ou seja, sem vazamento de gases. Esses gases gerados pela digestão anaeróbia possuem, além do odor altamente desagradável, grande potencial corrosivo.

Outros sérios problemas a serem solucionados são o acúmulo de material flutuante no interior das calhas coletoras de gases e a necessidade de haver um ponto de alimentação para cada 1,0 a 4,0 $\mathrm{m}^{2}$ do fundo da unidade. Essa imposição sempre resulta na execução de um complexo sistema hidráulico, que muitas vezes sofre com falhas decorrentes da execução e da manutenção.

Tem-se constatado, em reatores com vários anos de operação, graves problemas decorrentes do acúmulo de resíduos nas calhas coletoras de gases. Esse material sofre endurecimento, impede passagem livre de gases, e em casos extremos leva até à ruptura de componentes dessa calha.

Cabe ainda destacar o problema com a alta concentração de metano dissolvido no efluente do reator, comprometendo a qualidade deste. Heffernan et al (2011) relataram que a quantidade de metano dissolvido na saída dos reatores anaeróbios varia de 20 a $40 \%$ em relação ao total gerado no reator. Esse fato é influenciado principalmente pela temperatura (quanto menor a temperatura, maior a quantia de metano dissolvido). Os autores demonstraram como a concentração de metano é facilmente calculada a partir da Lei de Henry (solubilidade de gases em líquidos). Na Figura 3.6 são apresentados os resultados do exemplo de cálculo para a rota de conversão típica da matéria orgânica (levando-se em consideração pressão de 1 atm e temperatura de $20^{\circ} \mathrm{C}$ ).

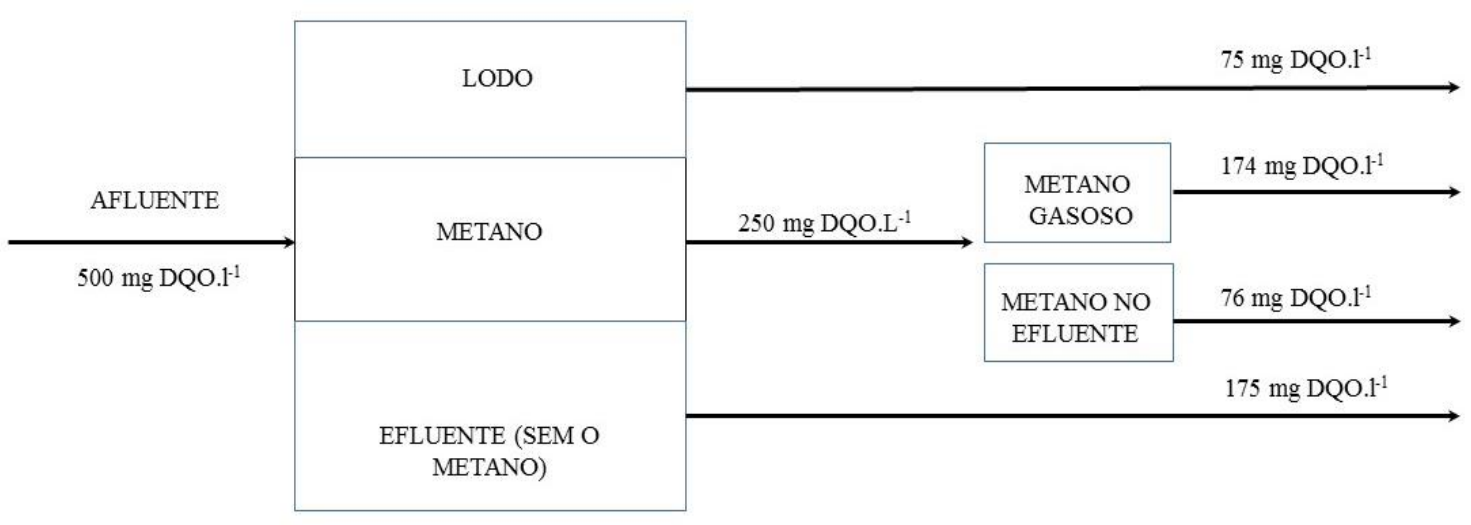

Figura 3.6: Exemplo de quantificação de metano dissolvido no efluente (HEFFERNAN et al, 2011) 
Souza et al (2011) quantificaram o metano produzido por dois reatores UASB tratando esgoto sanitário. $\mathrm{O}$ primeiro reator de volume $0,34 \mathrm{~m}^{3}$ foi operado com TDH de 5 e 7 horas; o segundo reator, de $14 \mathrm{~m}^{3}$, foi operado com TDH de 12 horas. Nos três ensaios a fração de metano dissolvido no efluente esteve entre 36 e $41 \%$ do total de metano gerado, resultado consoante ao indicado por Heffernan et al (2011).

Motivados pelo desejo de aumentar o desempenho dos reatores UASB, diversos pesquisadores e profissionais da área de saneamento vêm buscando o aperfeiçoamento dessa tecnologia - seja pela proposição de novos projetos ou de novas formas de operação dos reatores.

Seghezzo et al (1998) afirmam que um bom sistema de tratamento deve aliar um projeto simples a boa eficiência de remoção de poluentes. Para isso o uso de equipamentos sofisticados e o consumo energético devem ser os menores possíveis. No trabalho de van Haandel et al (2006), os autores explicam que as alterações aplicadas aos projetos de reatores anaeróbios visam dois objetivos principais: i) o primeiro, é a promoção de maior contato entre afluente e biomassa através de mistura intensa entre esses dois elementos; ii) o segundo objetivo é o de elevar a retenção da parcela mais ativa da biomassa, que é alcançada através do aprimoramento dos dispositivos de separação do líquido com os gases e sólidos.

Logo após o surgimento do reator UASB foi proposta uma simplificação da configuração original. Tratava-se do Anaerobic Baffled Reactor (ABR) que foi apresentado por Batchmann et al (1983) apud Nasr et al(2009). Em suma, esse reator pode ser descrito como uma série de reatores UASB sem separador de gases e sem sistema de decantação. A Figura 3.7 ilustra a configuração do reator ABR.

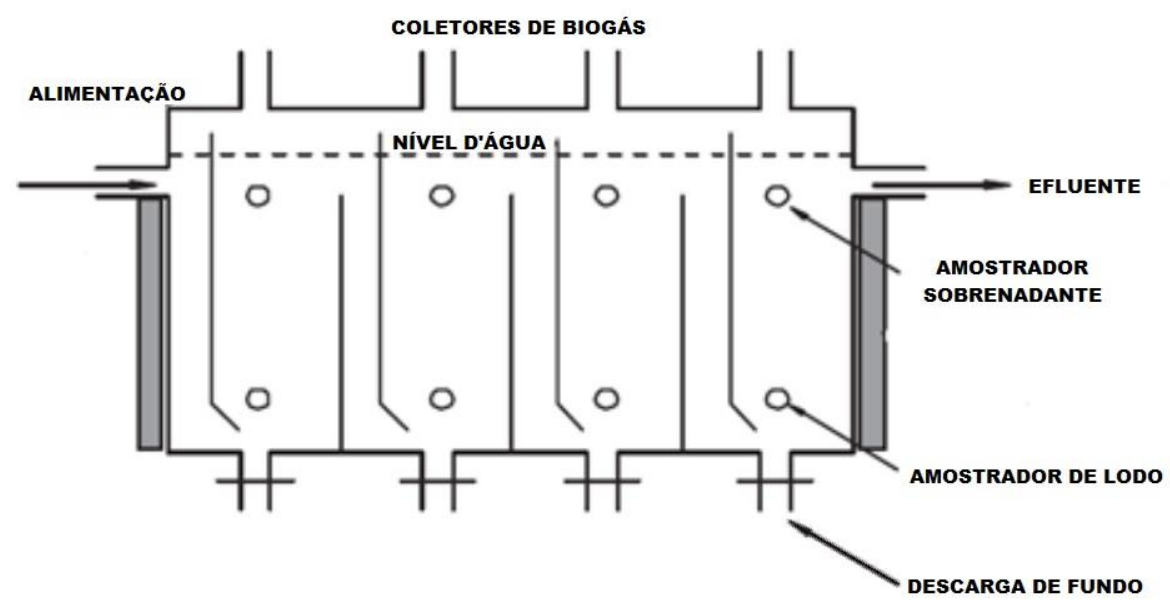

Figura 3.7: Esquema típico de um reator ABR (adaptado de NNAJI, 2014). 
O tratamento anaeróbio em ambientes de baixa temperatura gera baixo volume de gases. Como o reator UASB necessita da geração de gases para proporcionar mistura adequada entre o afluente e o lodo, seu desempenho em ambientes de baixa temperatura não gera resultados favoráveis. Em busca de um reator que proporcionasse melhor mistura do esgoto afluente com o lodo, minimizasse a ocorrência de zonas mortas, e mantivesse maior quantidade de biomassa ativa, foi desenvolvido o Expanded Granular Sludge Blanket (EGSB), ilustrado na Figura 3.8.

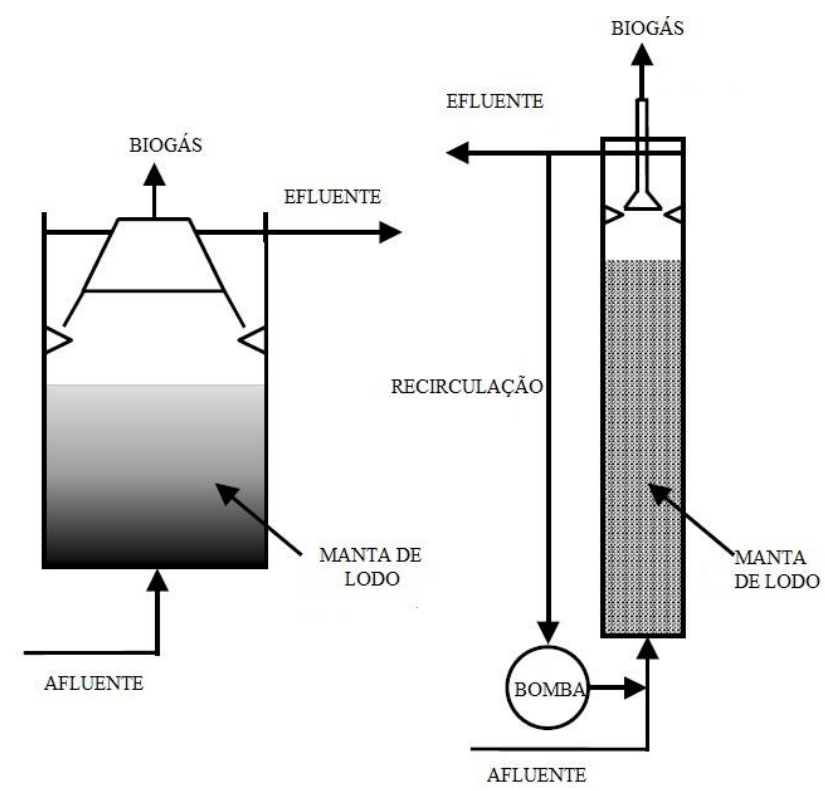

Figura 3.8: Esquema representando as diferenças do reator UASB (esquerda) e o reator EGSB (direita), (adaptado de SEGHEZZO, 2004).

Além dos exemplos citados acima, existem outras diversas adaptações de digestores anaeróbios com maior ou menor similaridade ao reator UASB. Dentre elas destacam-se os reatores de leito fixo, reatores com recirculação interna, reatores com zona de acidificação separada, reatores de mistura completa em batelada, reatores com leito fluidificado, reatores operados em duplo estágio. Maiores detalhes das configurações e desempenho desses reatores podem ser encontrados em Aiyuk et al (2006), van Haandel et al (2006) e Nnaji (2014).

\subsection{Atividade metanogênica específica}

A classificação e contagem dos micro-organismos presentes na biomassa do reator, tanto os metanogênicos quanto os não metanogênicos, exigem elevados níveis técnicos e 
equipamentos avançados e de grande custo, o que dificulta a execução dessa triagem (AGRAWAL et al, 1997).

Como alternativa econômica à classificação e contagem de micro-organismos presentes na biomassa do reator, surgiram os testes de avaliação da atividade metanogênica específica (AME) dos lodos anaeróbios. Segundo Chellapandi et al (2010), os testes de atividade metanogênica são úteis para a identificação e mensuração de compostos inibitórios, para a seleção de um determinado lodo como inóculo, para o estabelecimento da degrabilidade de substâncias específicas, etc..

$\mathrm{O}$ teste de atividade metanogênica específica avalia a capacidade das arqueas metanogênicas em converter a matéria orgânica em metano e gás carbônico. Para qualquer projeto, os testes de atividade metanogênica específica são importantes para avaliar a capacidade de remoção de DQO da fase líquida do esgoto no reator, obtendo-se a carga orgânica máxima que pode ser aplicada.

De acordo com Aiyuk et al (2006) a geração de biogás típica é de $0,5 \mathrm{~m}^{3}$ para cada quilograma de DQO removida. Se aproveitado o potencial energético desse gás, $0,5 \mathrm{~m}^{3}$ pode ser convertido em $1 \mathrm{kWh}$.

Nesta pesquisa, a determinação da AME será um dos recursos que serão aplicados para avaliar as características do lodo no reator, conforme constituída nessa nova concepção de reator.

Para Chernicharo (1997) e Aquino et al (2007), a comparação de resultados de AME entre trabalhos de diferentes autores deve ser cautelosa devido a não padronização de métodos para esta análise

Segundo Andreoli et al (2001), o lodo acumulado nos reatores é decorrente de dois processos: i) o primeiro, é a produção devido à remoção de material orgânico; ii) o segundo, se trata do acúmulo de sólidos não-biodegradáveis no sistema. À vista disso, se faz importante a avaliação da atividade biológica do lodo para constatação da potencialidade de degradação da matéria orgânica presente no efluente.

Penna (1994) verificou que o lodo alimentado com substratos sintéticos ou alimentado com a própria água residuária do sistema de tratamento de onde foi extraído resultou em valores similares da AME. Com isso ele sugere que se faça uso da água residuária como substrato na incubação do lodo, obtendo-se resultados com maior significado prático. 


\subsection{Suspensão de sólidos em meio líquido, por jatos}

\subsubsection{Generalidades}

Em sistemas de tratamento biológico, a mistura eficiente entre o efluente a ser tratado e a biomassa presente no interior do reator é um fator primordial para seu funcionamento adequado. Quando se trata de um sistema que necessita manter altas concentrações de massa biológica (manta de lodo), essa mistura deve ser realizada de forma criteriosa, para evitar a perda dessa biomassa junto à saída do sistema.

À vista disso, neste item são abordados os principais aspectos que influem na mistura realizada por meio de jatos, que realizarão a alimentação no reator proposto.

\subsubsection{Mistura por jatos}

A operação de mistura objetiva que os componentes presentes em um dado tanque ou reator constituam um único sistema, homogêneo ou não, a depender das fases observadas. Para tal efeito, torna-se necessária a intensificação dos fluxos de massa, quantidade de movimento e de energia, para garantir, através de uma agitação propícia, a formação do novo sistema. Para obter a agitação requerida, assim, é necessário que se transmita determinada potência (energia/tempo) para o líquido (SCHIMIDELL et al, 2001).

Utilizar jatos para misturar líquidos com partículas sólidas suspensas, apesar de não ser tão simples, pode propiciar considerável economia para se alcançar a mistura necessária. Essa economia é decorrente, sobretudo, devido às energias potencial e cinética do fluido afluente que promoverá a agitação - excluindo-se, portanto, a necessidade de gastos de instalação e operação de agitadores mecânicos (ATIEMO-OBENG et al, 2004).

Segundo Pope (2003), um jato simples, refere-se ao fenômeno em que um fluido escoa continuamente através de um bocal circular (fonte do jato) de diâmetro $D b(\mathrm{~m})$, produzindo um perfil de velocidade de saída $V_{j}\left(\mathrm{~m} \cdot \mathrm{s}^{-1}\right)$, e de escoamento simétrico em relação ao eixo do jato. Essas características podem ser observadas na Figura 3.9.

Quando a origem do jato é proveniente de um orifício de pequeno diâmetro, é correto afirmar que a velocidade no centro do jato é representativa da velocidade média de toda seção 
do jato. Essa situação permanece até a transição de um jato simples para um jato turbulento (que ocorre próximo ao bocal de origem, no fim do núcleo potencial). (GIORGETTI, 2008).

O fenômeno de transição de jato simples para jato turbulento dependente das características dos bocais e do fluido em que o jato é lançado. A partir do fim do núcleo (que ocorre a uma distância de um diâmetro do bocal, as camadas de mistura sofrem grande expansão devido à intensidade turbulenta local, o que é vantajoso para a mistura, visto que no interior do jato turbulento o gradiente de velocidade é mais elevado (LIMA, 2007).

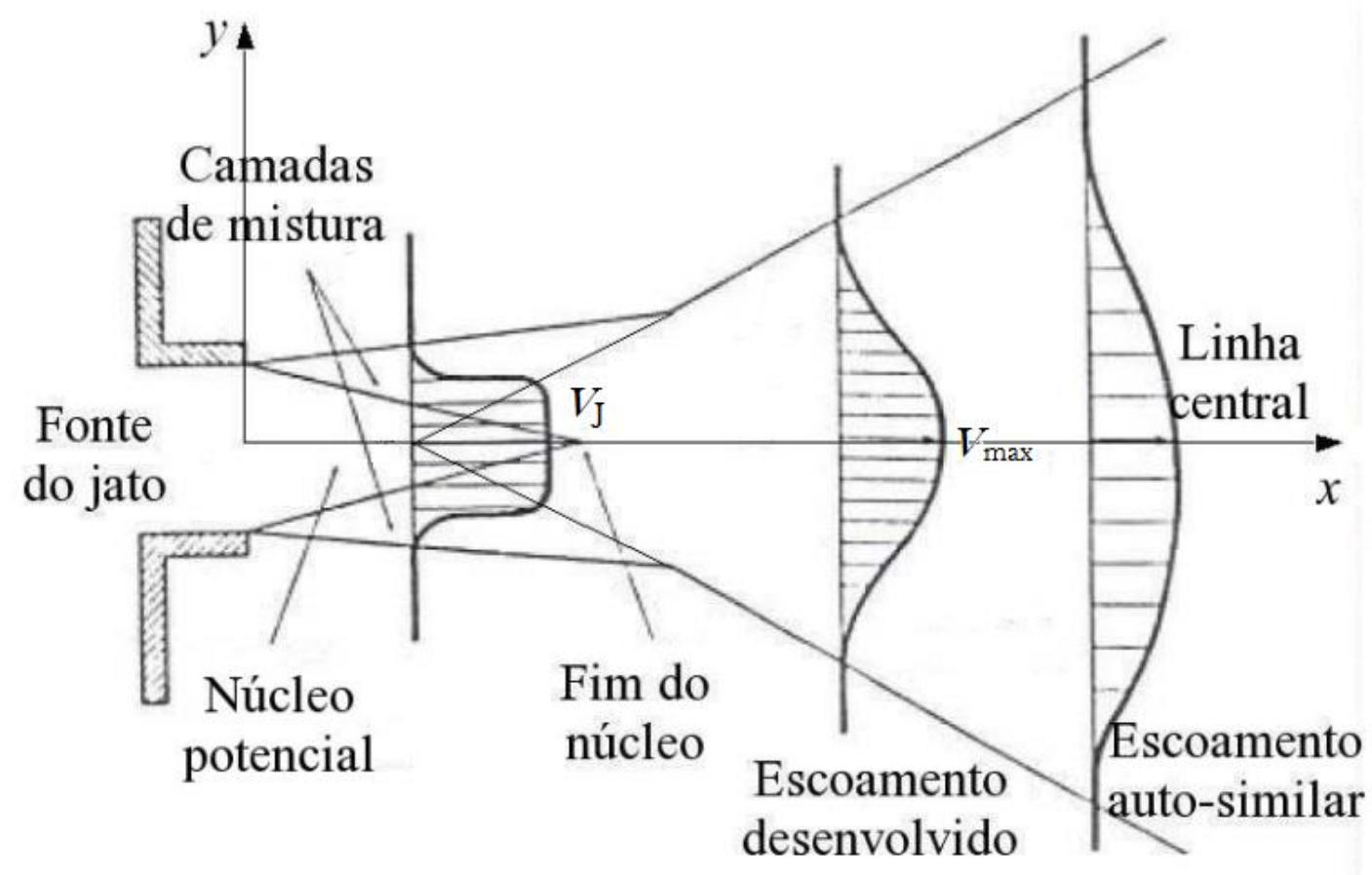

Figura 3.9: Desenvolvimento de um jato simples e sua propagação de velocidades ao longo do plano $\boldsymbol{x y}$ (adaptado de Souza, 2005).

O escoamento torna-se desenvolvido ou auto-similar com o decaimento do módulo velocidade do jato no eixo $\mathrm{x}$ e aumento do espalhamento no eixo $\mathrm{y}$. Tal perfil de desenvolvimento, que se aproxima de uma gaussiana típica, favorece o fluxo de massa no jato, uma vez que a dissipação e abertura espacial do jato aumenta o alcance da zona turbulenta. (LIMA, 2007).

Atiemo-Obeng et al (2004) sugeriram, neste contexto, alguns itens a serem seguidos para o sucesso no uso dos jatos para mistura: tubos e sondas devem ser apoiados nas paredes ou em defletores, para suportar as forças de reação impostas pelos jatos; a instalação de telas 
anteriormente aos bocais, para que sólidos grosseiros não sejam inseridos no fluido; e os bocais devem ser tão curtos quanto possível, para evitar que o escoamento desenvolvido nele, possa dificultar a transição para a turbulência.

\subsubsection{Bocais para geração de jatos}

Um bocal pode ser definido como uma peça hidráulica instalada em orifício (perfuração feita em tanques ou canalizações abaixo da superfície livre do líquido) com o objetivo de direcionar o jato, sendo possível aumentar a vazão de descarga a partir do formato de bocal adotado (AZEVEDO NETTO, 1998).

Quando se adiciona um bocal de formato cônico na extremidade de um orifício, novos pontos de perda de energia são criados e ocorre a diminuição da pressão interna do bocal, que passa a ser equivalente a 3/4 da carga atuante no bocal. Essa verificação foi realizada através do experimento de Venturi, que está ilustrado na Figura 3.10 (AZEVEDO NETTO, 1998). Assim, a descarga ocorre com uma vazão maior, da ordem de até $34 \%$. Sabe-se também que da carga hidráulica total que atua num bocal $2 / 3$ se convertem em velocidade, cuja energia será dissipada no meio. Essa carga atuante é proveniente da cota do nível d'água no tanque de alimentação.

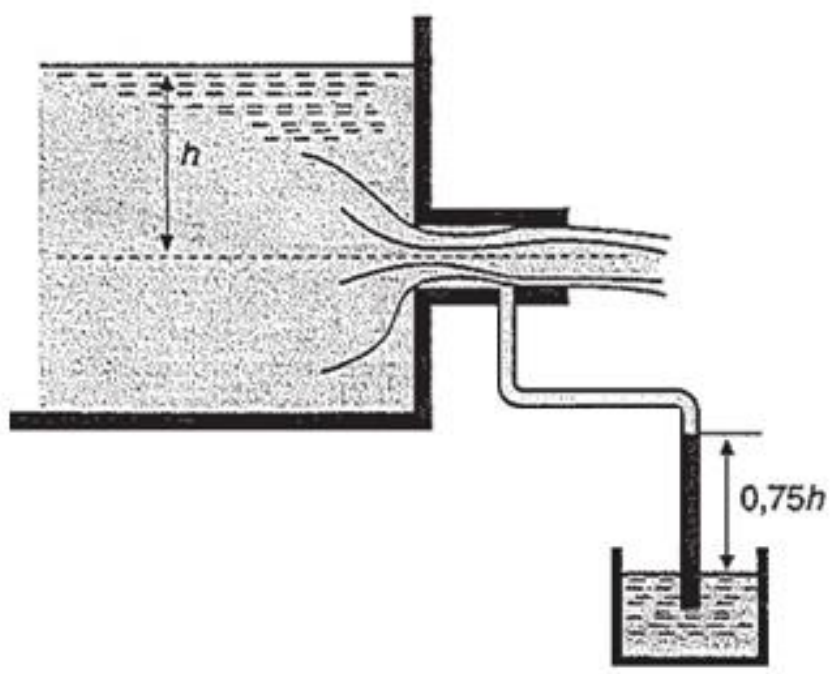

Figura 3.10: Experiência de Venturi (AZEVEDO NETTO, 1998). 
Para o cálculo da vazão através do bocal, aplica-se equação de Bernoulli ao escoamento, resultando na chamada lei dos orifícios, mostrada na Equação 3.1. Esta fornece a vazão do escoamento no orifício em função da área, da altura manométrica, da velocidade gravitacional e do coeficiente de vazão (LENCASTRE, 1957).

$$
Q=C D \cdot A b \cdot \sqrt{2 \cdot g \cdot h}
$$

Em que: $C D$ representa o coeficiente de descarga; $A b$ é dada como a área da sessão contraída do bocal; $g$ representa a aceleração gravitacional $9,8 \mathrm{~m} \cdot \mathrm{s}^{-2} ; h$ a carga altimétrica (mca).

O coeficiente de descarga (CD) é obtido através do produto entre o coeficiente de contração (CC) da veia líquida - trata-se da relação entre a área do jato e a área do bocal - e o coeficiente de correção de velocidade (CV - que é a relação entre a velocidade real e a velocidade teórica do jato). A Figura 3.11 ilustra os coeficientes típicos para cada tipo de bocal.

Segundo Azevedo Netto (1998), os bocais divergentes com ângulo de $5^{\circ}$ permitem os maiores coeficientes de descarga. A diferença entre bocais convergentes e divergentes são mostrados na Figura 3.12.

Shuja (2005) realizou estudo sobre a influência das características geométricas de bocais cônicos e circulares na velocidade do escoamento. O autor notou que o aumento do ângulo do bocal cônico provoca acréscimo na aceleração do escoamento na região próxima ao orifício de saída, enquanto a variação da aceleração obtida pelos bocais cilíndricos foi menos significante.

Em relação ao alcance lateral e longitudinal do jato gerado por um bocal, este é dado em função da velocidade e diâmetro da saída do bocal, e da velocidade final desejada para o jato, conforme Equação 3.2 e 3.3 (HARNBY et al, 2001).

$$
\begin{gathered}
Z=\frac{V j \times D c \times 6}{V Z} \\
A L=\frac{Z}{6}
\end{gathered}
$$

Em que: $Z$ representa o alcance máximo do jato para velocidade adotada $(\mathrm{m})$; $V j$ representa a velocidade do jato na saída do bocal $\left(\mathrm{m} . \mathrm{s}^{-1}\right) ; D c$ representa o diâmetro do bocal 
na saída do jato $(\mathrm{m}) ; V Z$ representa a velocidade mínima requerida (adotada, $\mathrm{m} . \mathrm{s}^{-1}$ ); e $A L$ representa o alcance lateral do jato no ponto $Z$ (m).

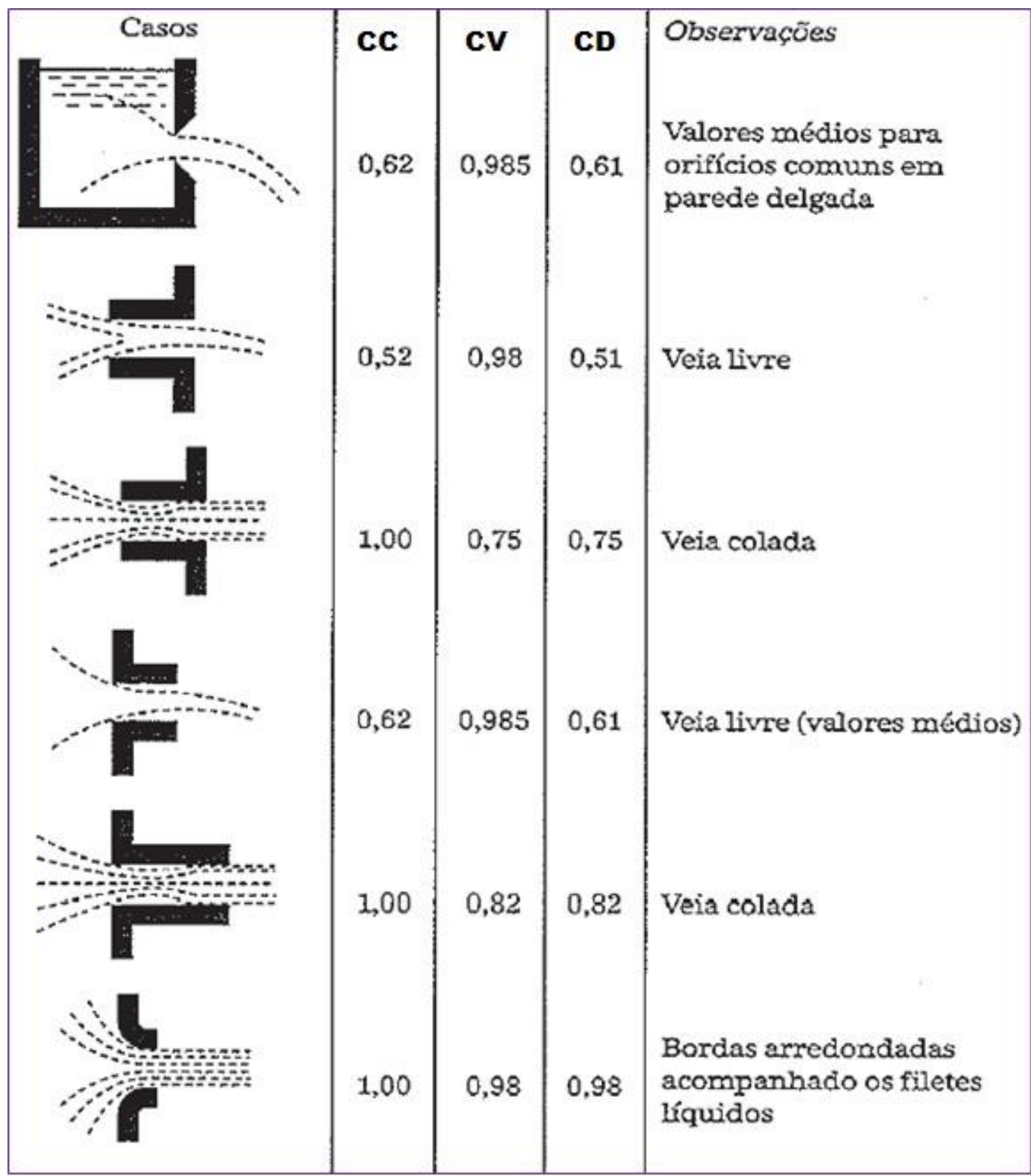

Figura 3.11: Coeficientes de contração, velocidade e descarga para cada aplicação de bocais (Azevedo Netto, 1998). 

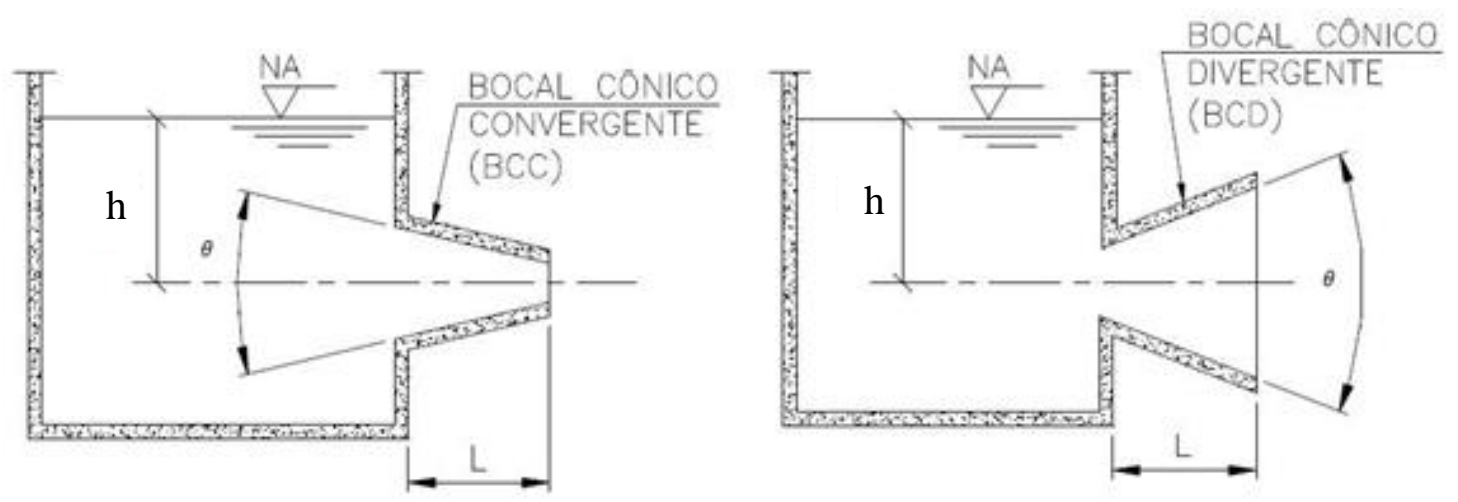

Figura 3.12: Bocais cônicos a partir de uma angulação $\boldsymbol{\theta}$ (Porto, 2006).

\subsubsection{Tanques com conteúdo misturado por jatos}

A agitação mediante o uso de jatos, como já foi sugerido no início do presente item, é uma alternativa atraente para ser usada em diversos tipos de unidades destinadas ao tratamento de esgoto, sobretudo quando se necessita promover mistura de reagentes químicos, aumento da transferência de massa e calor, suspensão da massa sólida, prevenção de estratificação ou, simplesmente, quando se deseja promover homogeneização do sistema.

A formação de turbulência no líquido a ser agitado ocorre devido às diferenças de velocidade existente entre o líquido em repouso (ou, praticamente) e o jato que entra em contato com essa massa líquida. Essa divergência de quantidade de movimento provoca arrastes na massa líquida, fazendo com que o jato aumente seu diâmetro e diminua a velocidade no eixo central. (PATWARDHAN e GAIKWAD, 2003).

O uso de jatos para mistura de líquidos como alternativa ao uso de agitadores mecânicos ocorre há várias décadas; mesmo assim, os aspectos hidrodinâmicos envolvidos no processo ainda não são plenamente conhecidos (SARAVANAN et al, 2010).

Algumas empresas possuem setores especializados nessa linha, nas quais são projetados e produzidos sistemas de agitação com o uso de jatos de acordo com a demanda de cada usuário; seja para sistemas de tratamento de efluentes (digestores anaeróbios para lodo, reatores aeróbios, tanques de equalização, etc) seja para outras atividades em indústrias químicas e alimentícias, por exemplo. Dentre essas empresas podem-se citar: Siemens (Alemanha); ITT water and wastewater KLA Systems, Mixing Systems (Estados Unidos), MAMKO (Índia), 
Alfalaval (Suécia), etc.. As principais vantagens sugeridas por essas empresas, e outras afins, são o baixo consumo energético e a facilidade de manutenção dos equipamentos envolvidos. A Figura 3.13 apresenta dois desses sistemas comerciais de agitação por jatos. Na Figura 3.13A observa-se a disposição dos bocais no fundo de um tanque circular; e, na Figura 3.13B nota-se o alcance dos jatos. Na Figura 3.14 pode-se observar, de perto, a formação do jato pela adição do bocal;
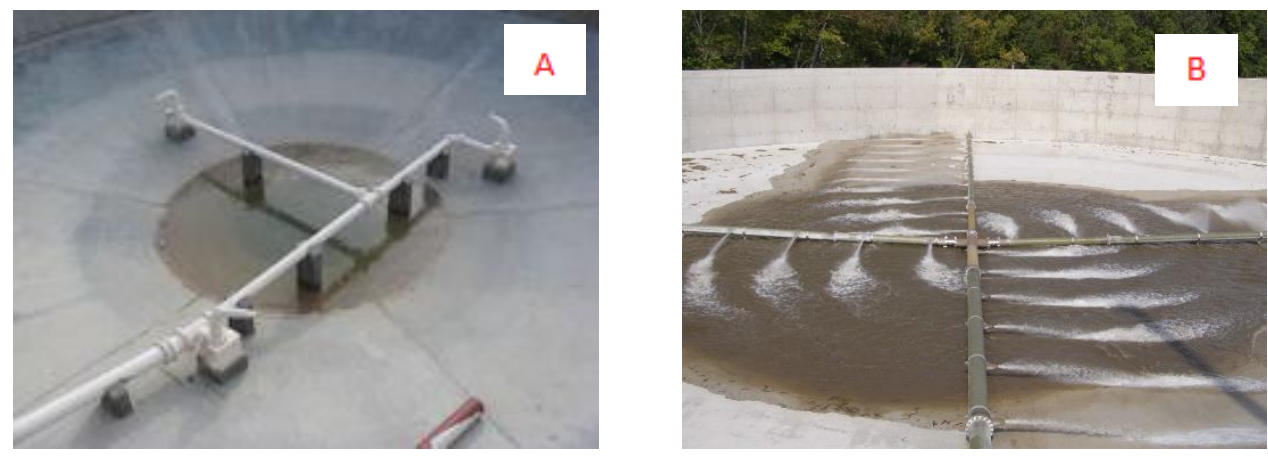

Figura 3.13: Exemplos comerciais de sistemas agitadores por jatos: A) Siemens, B) Mixing Systems Registred.

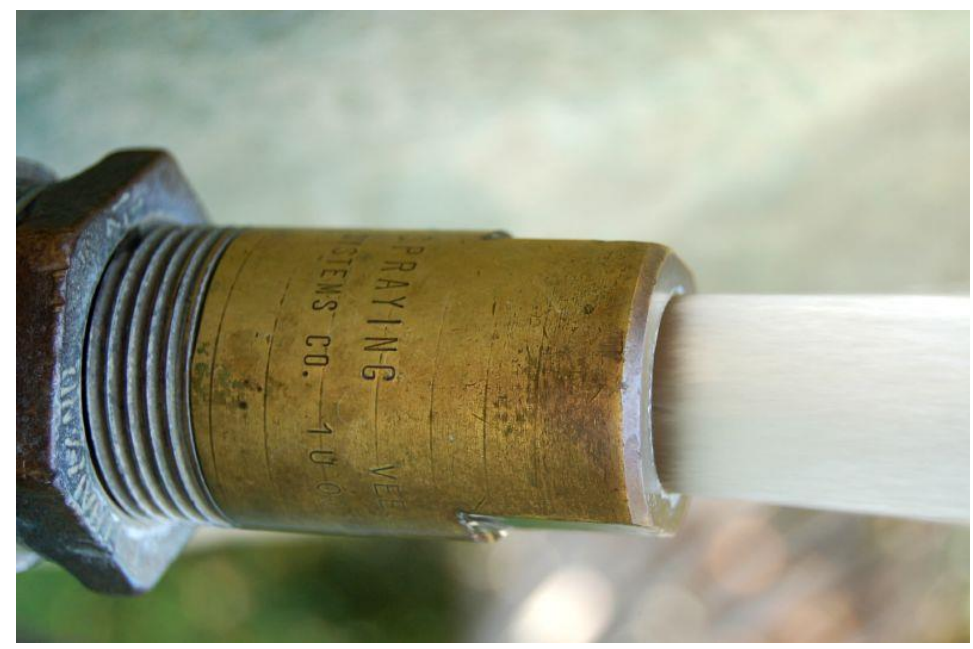

Figura 3.14: Exemplo de jato de água proporcionado pela adição de um bocal na extremidade de uma canalização.

Saravanan et al (2010) apontaram diversas vantagens do uso de jatos para promover a mistura de sistemas líquidos em relação ao uso de agitadores mecânicos convencionais, dentre os quais podem-se destacar: ausência de peças com movimento, o que reduz o custo com manutenção e simplifica a instalação; tanques de paredes menos espessas ou de material mais simples, pois a mistura por jatos não necessita de suporte no topo do tanque (esse suporte é 
comum na instalação dos misturadores mecânicos que precisam de algo para suportar sua massa).

Diversos trabalhos revelaram que o comportamento da mistura promovida por jatos depende, em grande parte, dos aspectos construtivos do sistema de alimentação e do próprio tanque onde se pretende obter a mistura.

O principal parâmetro utilizado para analisar os trabalhos de agitação, e que serve de medida para comparações, é o tempo de mistura. Este parâmetro refere-se ao tempo necessário para que $95 \%$ do fluido do tanque seja influenciado pelo jato de mistura - para essa avaliação são usados traçadores no jato de entrada. Nos próximos itens é dada mais ênfase aos aspectos construtivos e sua influência na mistura.

\subsubsection{Efeito do ângulo de incidência do bocal}

Harnby et al (2001) descreveram que uma forma de se utilizar os jatos para mistura dos sólidos é promovendo arranjo de vários jatos em diferentes posições para que possa haver a mistura de várias camadas. Essa observação foi muito útil no desenvolvimento desta pesquisa já que a manta de lodo trata-se de estrutura estratificada.

Quando existe pequena diferença de densidade e viscosidade entre o fluido proveniente do jato e o fluido secundário que se encontra no tanque, é necessário que o bocal gerador do jato seja disposto com certo ângulo de inclinação em relação à base horizontal do tanque, para que o jato possa provocar a mistura nesse ambiente estratificado. Esse bocal pode ser disposto tanto em partes superiores do tanque, quanto nas partes inferiores (HARNBY et al, 2001).

Patwardhan e Gaikwald (2003) observaram que os jatos paralelos ao fundo do tanque exigem tempo de mistura maior que o dos jatos inclinados; situação que pode ser compensada com o aumento do diâmetro do bocal (segundo os mesmos autores). Esse estudo foi realizado em tanque de acrílico de diâmetro $0,50 \mathrm{~m}$ e altura $0,75 \mathrm{~m}$. A entrada do líquido se deu por bocal localizado a $5 \mathrm{~cm}$ do fundo do tanque. Foi variado o diâmetro interno do bocal (5 a $39 \mathrm{~mm}$ ) e os ângulos de incidência deste ( 0 a $90^{\circ}$ em relação ao fundo). A Figura 3.15 ilustra os resultados desse trabalho.

A explicação para os jatos promoverem maior mistura, quando estão inclinados, é que, nessa configuração, o percurso do jato até atingir a parede do tanque é mais longo, assim a 
expansão lateral do jato é maior (como foi explicado no item 3.4.2), e, consequentemente maior volume do líquido é influenciado pelos jatos inclinados. Isso foi provado através de estudo experimental e mediante análise computacional (PATWARDHAN E THATTE, 2004).

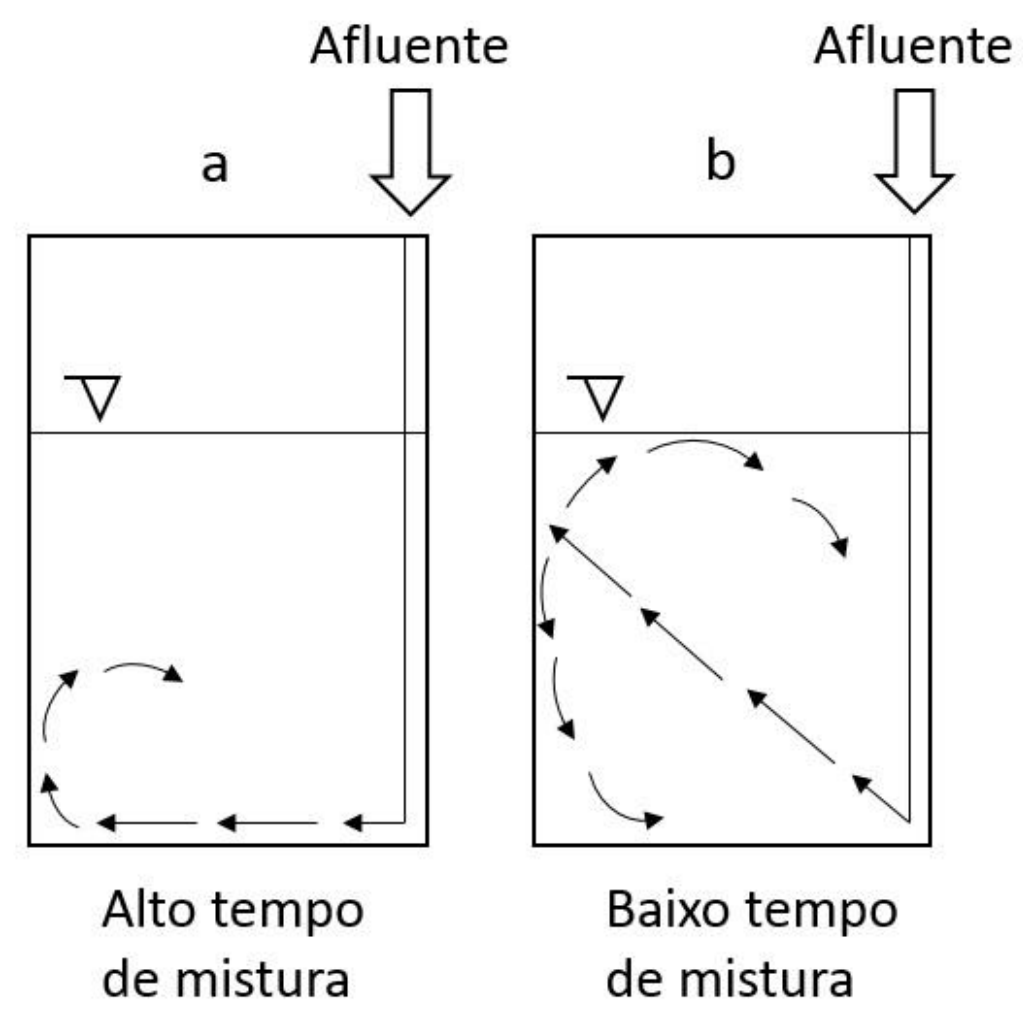

Figura 3.15: Representação da agitação causada por jato horizontal(a) e por jato inclinado(b), (adaptado de PATWARDHAN E GAIKWAD, 2003).

Kalaichelvi et al (2007) também concluíram - através da injeção de traçadores e determinação do tempo de mistura — que os jatos inclinados são mais eficientes para promoção de mistura, e, ainda observaram que o ângulo de $30^{\circ}$ foi o mais eficiente, como pode ser observado na Figura 3.16. Ressalta-se também que a configuração do tanque tem grande influência no comportamento dos jatos, pois a mistura depende em grande parte da massa líquida revolvida pelo jato até o encontro com a parede. $\mathrm{O}$ objeto desse estudo foi um tanque de $28 \mathrm{~cm}$ de altura por $28 \mathrm{~cm}$ de diâmetro preenchido com água, e os ângulos de incidência testados foram de $0^{\circ}, 15^{\circ}, 30^{\circ}, 45^{\circ}$ e $60^{\circ}$. Não foram fornecidas informações sobre o tipo de bocal utilizado e velocidade do jato. 


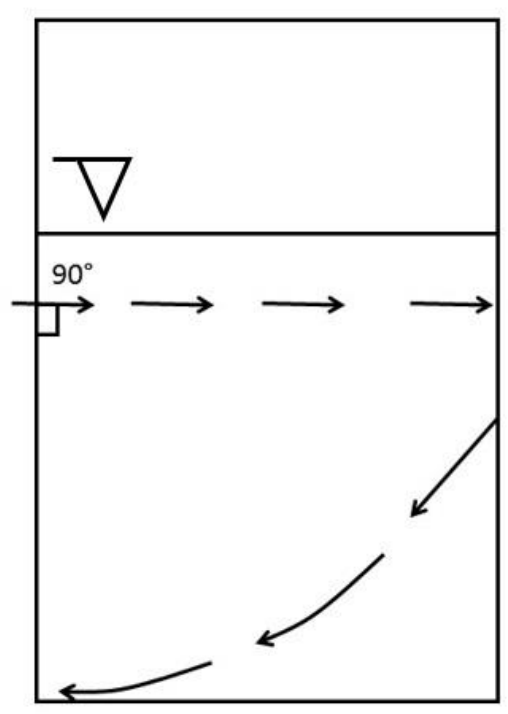

Tempo de mistura elevado

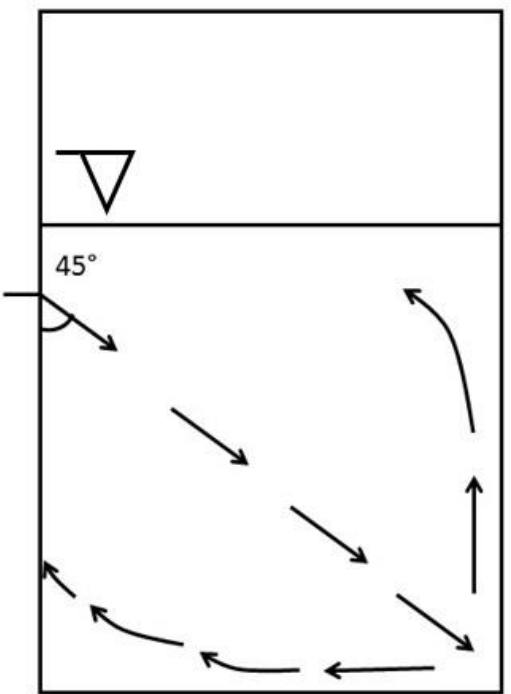

Tempo de mistura mediano

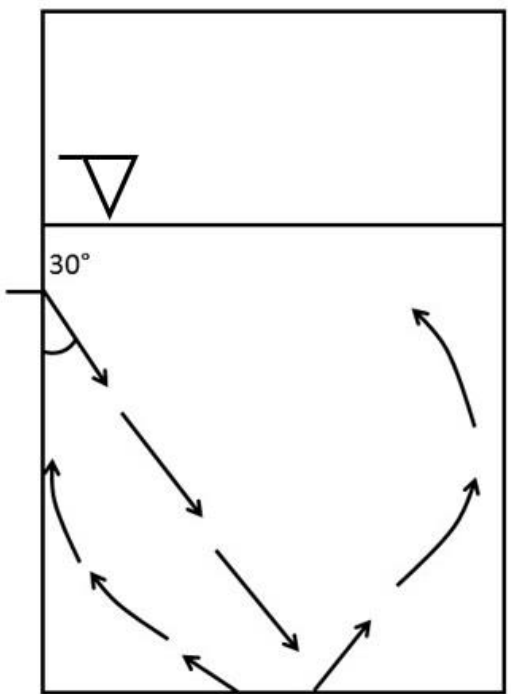

Tempo de mistura baixo

Figura 3.16: Representação da agitação causada por bocais inclinados a $0^{\circ} ; 45^{\circ}$ e $30^{\circ}$ respectivamente, em relação à parede lateral do tanque (adaptado de KALAICHELVI et al, 2007).

\subsubsection{Efeito do diâmetro do bocal}

Patwardhan e Gaikwad (2003), e Kalaichelvi et al (2007) concluíram que quanto maior o diâmetro do bocal, menor o tempo de mistura necessário, independente do ângulo de incidência deste. Porém aumenta-se a demanda energética para que a velocidade do bocal de maior diâmetro seja igual à velocidade do bocal de menor diâmetro.

Segundo Perumal e Saravanan (2012), o diâmetro do bocal é o fator mais importante para se entender a hidrodinâmica de um tanque com volume misturado por jatos. Além disso, ele defende que esses aspectos hidrodinâmicos são muito específicos para cada formato de tanque. Nesse estudo foi avaliada a potência dos jatos em tanque de $50 \mathrm{~cm}$ de diâmetro por 60 cm de altura; variou-se o diâmetro do bocal $(10 ; 15$ e $22 \mathrm{~mm}$ ) e altura de entrada (a $21 ; 27$ e 30 $\mathrm{cm}$ do fundo do tanque) e manteve-se vazão de entrada constante $\left(0,81 . \mathrm{s}^{-1}\right)$. O menor bocal estudado (10 mm de diâmetro) teve a melhor potência de mistura (nesse estudo o parâmetro utilizado para a comparação dos resultados foi a fração de massa líquida revolvida instantaneamente). Em relação à altura do bocal, não houve diferenças significativas na potência de mistura. Os autores não informaram o tipo e geometria do bocal empregado. 


\subsubsection{Efeito da velocidade do jato}

Zughbi (2007), utilizando modelagem numérica, variou o número de Reynolds do jato entre 81.856 e 32.799 , e avaliou as velocidades medidas dentro de um tanque em forma de cilindro de 0,6 m de diâmetro por 3,0 m de comprimento. O bocal de entrada possuía $41 \mathrm{~mm}$ de diâmetro. A Figura 3.17 mostra as velocidades $\left(\mathrm{m}^{-1} \mathrm{~s}^{-1}\right.$ ) alcançadas pelo jato no interior do tanque. Pode-se notar grande influência do número de Reynolds na velocidade do fluido no interior do tanque, tendo por consequência um forte efeito de parede que provoca agitação na parte superior do tanque. Dessa forma, se for desejável que não ocorra agitação na parte superior do tanque, é recomendável o uso de jato com menores velocidades de entrada. $\mathrm{O}$ autor ainda testou a influência do posicionamento do jato de entrada, concluindo que o tempo de mistura (95\% do volume sob efeito do jato) pode variar em até $600 \%$.

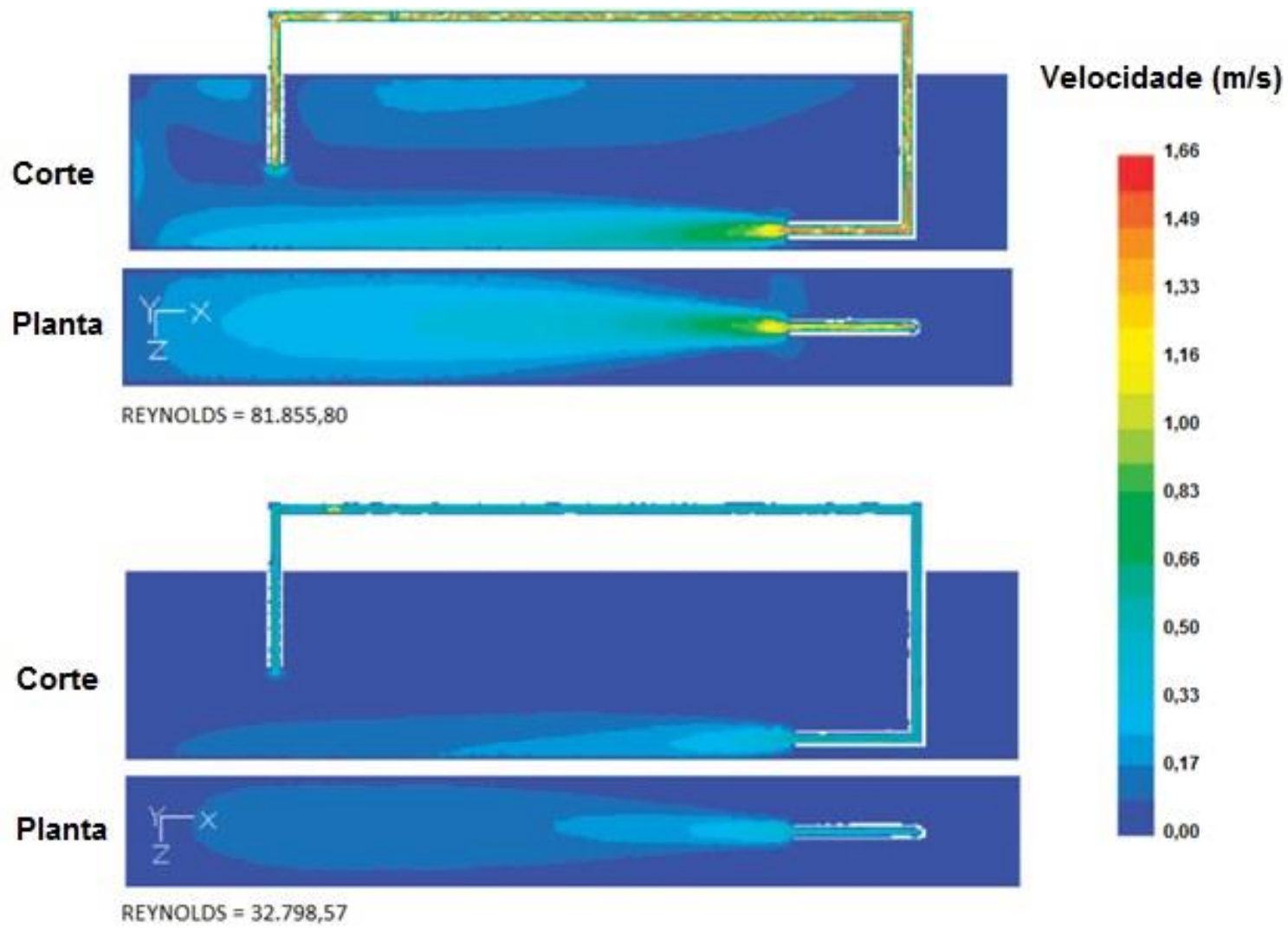

Figura 3.17: Variação da velocidade $\left(\mathrm{m} . \mathrm{s}^{-1}\right)$ dos jatos no interior de um tanque, e influência na agitação deste (adaptado de ZUGHBI, 2007). 


\subsubsection{Efeito do formato do tanque}

Zughbi et al (2006) concluíram que um tanque de fundo cônico possui tempo de mistura até $25 \%$ menor que um tanque de fundo plano. O uso de jatos assimétricos ou a inserção de defletores contribuíram para aumentar a mistura, mesmo no tanque de fundo plano.

Patwardhan e Thatte (2004) estudaram a influência do diâmetro do tanque, concluindo que o tempo de mistura é muito menor em tanques de menor diâmetro. Para um jato de velocidade $1,1 \mathrm{~m} . \mathrm{s}^{-1} \mathrm{o}$ tempo de mistura foi de $17 \mathrm{~s}$ e de $53 \mathrm{~s}$ para tanques de diâmetro $50 \mathrm{~cm}$ e $100 \mathrm{~cm}$ respectivamente. $\mathrm{O}$ estudo foi realizado utilizando tanque preenchido com água e bocais de $38 \mathrm{~mm}$ de diâmetro (não foi informado o tipo de bocal utilizado).

\subsubsection{Comentários gerais sobre agitação por meio de jatos promovidos por bocais}

Com base nas fontes citadas ao longo do item 3.4, pôde-se elaborar uma síntese dos temas abordados e de interesse para a presente pesquisa.

Devido a vários fatores destacados nos itens anteriores Jayanti (2001) ainda relatou que um tanque ideal para a mistura de determinado fluido depende muito de combinação de vários parâmetros, que por vezes é única. O autor propõe que a melhor geometria é aquela que reflita num balanço ideal entre tempo de mistura e "força" do jato desejados.

Quase a totalidade dos estudos e aplicações de jatos para mistura apresentados nesta revisão utilizaram-se de fluidos sob pressão, ou seja, a alimentação dos bocais que promovem esses jatos é feita através de bombas, o que acarreta maiores custos com consumo energético e manutenção desses equipamentos.

É importante ressaltar que o grande diferencial deste projeto de pesquisa é a utilização da carga manométrica presente no afluente armazenado, o que possibilita, em princípio, a exclusão do sistema de bombeamento (para obtenção da carga manométrica). Essa forma de alimentação é possível, pois a energia necessária para misturar o lodo com o efluente é baixa, devido, em grande parte, à baixa densidade do lodo. Dessa forma o sistema de alimentação tem menor custo operacional e de instalação. 
Enfim, nota-se que, para obter boas condições de mistura, é recomendável o uso de bocais cônicos, que forneçam jatos com altas velocidades, dispostos inclinados em relação ao fundo dos tanques, e, de preferência, que esses tanques sejam cilíndricos e com fundo hemisférico. Nas instalações experimentais que serão destacadas no item Materiais e Métodos, não será possível trabalhar com todas essas condições ótimas uma vez que as estruturas dos reatores serão derivadas de pesquisas anteriores.

\subsection{Filtro rápido de areia}

O efluente dos reatores UASB, e de outros sistemas de tratamento anaeróbios, possui grandes concentrações de partículas em suspensão que acarretam acréscimo significativo do valor da matéria orgânica residual do tratamento. Para a remoção de sólidos suspensos e de partículas coloidais é usual a utilização de processos de filtração.

Geralmente os efluentes de reatores UASB apresentam teor de sólidos em suspensão (para esgoto sanitário), da ordem de 50 a $120 \mathrm{mg}, \mathrm{l}^{-1}$, que pode corresponder a uma DBO na faixa de 20 a 50 mg. $1^{-1}$, considerando-se estimativas grosseiras. Portanto, a remoção de parcela significativa desses sólidos, em filtros pode resultar um sistema que pode ter eficiência aceitável para muitos cenários de lançamento.

Os filtros de areia foram propostos, inicialmente, para a remoção de turbidez de água potável, porém desde o século XIX passaram a ser, também, utilizados no tratamento de esgoto (MICHELS apud TONETTI et al 2004).

No tratamento de esgoto, os filtros de leito fixo, de membranas e os de superfície são os principais tipos empregados, sendo, os primeiros, de instalação e operação mais econômicas, porém com eficiências menores (TCHOBANOGLOUS et al, 2004).

Isso não impede, porém, que se adotem filtros rápidos com leito de areia nos casos em que o efluente não necessita atingir qualidade restritiva para usos mais nobres ou quando se realiza o lançamento em corpos receptores ou, ainda, precedendo filtração e membranas. Eles podem constituir uma unidade que aprimora o efluente tratado biologicamente.

O tratamento terciário de efluentes sanitários por meio de filtros já era amplamente utilizado na década de 1970, quando a EPA elaborou levantamento que apontou várias estações 
americanas utilizavam essa tecnologia (USEPA, 1980). Tebutt (1971) relatou que a filtração rápida por gravidade era o método de tratamento terciário mais utilizado à época.

A diferença entre filtros rápidos e lentos não reside, somente, na diferença de taxa de filtração, mas também no conceito de tratamento. Enquanto os filtros lentos são um processo majoritariamente biológico, os filtros rápidos são considerados como uma operação física de tratamento. Os filtros lentos necessitam de leito de filtração de granulometria pequena, o que implica em menores taxas de aplicação superficial, e leva à formação de camada biologicamente ativa (próxima a superfície) que potencializa a remoção de micro-organismos e nutrientes. Além disso, requerem baixa turbidez e não respondem bem a grandes variações na qualidade do efluente (BRINCK, 2009).

A filtração rápida em meio granular ocorre através de um conjunto de subcamadas que vão exaurindo continuamente a sua capacidade de retenção de partículas. Nesse processo, mecanismos de transporte atuam conduzindo partículas suspensas para as proximidades da superfície do material filtrante.

Em contrapartida, os mecanismos de aderência devem proporcionar resistência às forças de cisalhamento resultantes das características hidrodinâmicas do escoamento ao longo do meio filtrante, garantindo a aderência das partículas à superfície dos coletores. O mecanismo de desprendimento é resultado da superação das forças de aderência pelas forças de cisalhamento do escoamento, e faz com que as partículas migrem para a camada subsequente do meio filtrante (inferiores, no caso de filtros descendentes e superiores, no caso de filtros ascendentes), viabilizando a filtração com ação de profundidade.

A escolha de uso de filtros rápidos se dá quando há pouca área disponível, quando se prioriza menores custos de operação, ou quando a turbidez e concentração de SST do efluente a ser tratado é mais elevada; porém a qualidade do efluente filtrado não é a mesma quando do tratamento em filtros lentos. Segundo Tebutt (1971) os filtros de fluxo ascensional resultam em filtrados de melhor qualidade tanto para água quanto para esgoto, porém ainda se usa o de gravidade (fluxo descendente) devido a maior simplicidade de operação.

Por se tratar de uma operação predominantemente fundamentada em fenômenos físicos, a turbidez de entrada não é um fator determinante, e o tempo de duração da carreira dependerá muito da concentração de SST do afluente.

A carreira de filtração é determinada pelo intervalo de tempo entre o início de operação de filtro e sua parada para lavagem. A lavagem deve ocorrer quando a perda de carga atingir a carga hidráulica disponível, ou quando algum padrão limite for extrapolado, sendo que um filtro 
"otimizado" busca a ocorrência simultânea das duas situações. O padrão usado como limite depende da qualidade do filtrado desejado, e pode ser a concentração de sólidos suspensos totais, número de turbidez, número de coliformes, concentração de matéria orgânica, entre outros.

Para o prolongamento da duração da carreira de filtração os aspectos mais importantes a serem observados são o tamanho efetivo e o coeficiente de não-uniformidade $(\mathrm{Cn})$ dos grãos. Henriquez (1988) observou carreiras de filtração mais longas quando coeficiente de não uniformidade aproximou-se de 1,00; Prezzoti (1990) concluiu que o diâmetro efetivo dos grãos tem menos influência na duração de carreira que o coeficiente de não-uniformidade.

Quando for atingido o final da carreira de filtração deverá ser realizada lavagem do filtro. Essa lavagem objetiva expandir o leito filtrante de $30 \%$ a $50 \%$ de seu volume, utilizando água e ar, simultaneamente, ou não. Para conseguir tal expansão, seria necessário um volume de água muito elevado caso não fosse utilizado o ar como auxiliar (DI BERNARDO, 1988).

Segundo Tchobanoglous et al (2004), a filtração de esgoto é mais complexa que a filtração de água potável devido as altas concentrações de sólidos e de matéria orgânica. Sendo assim, a taxa de aplicação depende, além do tamanho dos grãos do material filtrante, das características do efluente a ser filtrado. Como exemplo os autores sugerem taxa de aplicação superficial (para efluentes de sistemas de lodos ativados) entre 115 e $460 \mathrm{~m}^{3} \cdot \mathrm{m}^{-2} \cdot \mathrm{dia}^{-1}$, determinada de acordo com a resistência dos flocos. Flocos fracos tendem a ser arrastados junto do filtrado.

Segundo relatório da EPA, a remoção de sólidos suspensos em filtros rápidos não é mais significativa quando a taxa de carregamento hidráulico passar de $580 \mathrm{~m}^{3} \cdot \mathrm{m}^{-2} \cdot \mathrm{dia}^{-1}$. Abaixo desse valor a remoção de sólidos varia de 60 a 90\% dependendo dos grânulos utilizados como meios de filtração (USEPA, 1975).

Alguns aspectos construtivos foram discutidos por Yves (1970): para o leito de filtração é recomendado o uso de areia com diâmetro efetivo entre 0,4 e $1,0 \mathrm{~mm}$ e de 1,0 a 2,5 $\mathrm{mm}$ para o tratamento de água de abastecimento e para o tratamento terciário de esgotos, respectivamente (a EPA recomenda o uso de areia de diâmetro entre 0,4 e 2,0 $\mathrm{mm}$ ). Quando a perda de carga no sistema é muito elevada, é recomendado o uso de antracito no lugar da areia. Para esse tipo de filtro é usual a aplicação de $30 \mathrm{mg} . \mathrm{l}^{-1}$ de SST visando remoção de até $65 \%$ na concentração de sólidos suspensos.

Em relação à carga máxima aplicada — que favorece a filtração em profundidade, mas sem arraste de impurezas - Vigneswaram et al (2009) apontaram que esta deve ter no máximo 
3,0 m para tratamento terciário de esgoto. Esse valor é muito próximo à perda de carga aplicada para águas de abastecimento, que deve ser de 2,4 m a 3,0 m, segundo Freire (1983).

Caso seja necessário priorizar a remoção de patógenos, o filtro de areia é considerado uma boa alternativa. A eficiência de remoção de vírus e bactérias pode atingir valores de até 90\%, valor este que pode aumentar ainda mais, caso haja a aplicação de polímeros auxiliares de filtração. Dessa forma a filtração pode até ser considerada como um sistema de desinfecção (USEPA, 2012).

O valor típico de sólidos suspensos totais no filtrado de efluentes tratados em lodos ativados, em filtro de areia rápido, é da ordem de 2 a $8 \mathrm{mg}$. $\mathrm{L}^{-1}$. Já a remoção de DQO varia muito em função da parcela de DQO particulada presente no efluente do tratamento secundário. Esses filtros de areia não são muito eficazes para remoção de vírus, mas podem atingir até $2 \log$ de eficiência de remoção de coliformes totais (ASANO et al 2007).

Gobbi (2010) realizou estudo com filtro de areia como pós-tratamento do efluente de um sistema de lodos ativados da ETE ABC, em São Paulo, SP - Brasil. O foco do trabalho foi avaliar a remoção de ovos de helmintos que encontravam-se em torno de 22 ovos por litro naquela estação. $\mathrm{O}$ filtro utilizado era formado por 1,0m de leito de areia (tamanho efetivo dos grãos de 0,6 mm e coeficiente de não-uniformidade de 1,7) e foi submetido a taxas de 180, 240 e $360 \mathrm{~m}^{3} \cdot \mathrm{m}^{-2} \cdot \mathrm{dia}^{-1} \mathrm{sem}$ nenhum tipo de coagulante. $\mathrm{O}$ filtrado resultou em densidades inferiores a 1 ovo. $\mathrm{L}^{-1}$ para as três taxas de aplicação. O autor ainda inseriu ovos de helmintos em outro teste, para obter densidade inicial de helmintos de 1000 ovos. $\mathrm{L}^{-1}$. O filtrado resultante mantevese com concentração de helmintos inferior a 1 ovo. $\mathrm{L}^{-1}$.

A remoção de SST, DQO e coliformes também foi avaliada no trabalho de Gobbi (2010). Em relação à DQO a média de entrada foi de $51 \mathrm{mg} . \mathrm{L}^{-1}$ e de saída de $34 \mathrm{mg} . \mathrm{L}^{-1}$. A entrada média de SST foi de 5,2 mg.L $\mathrm{L}^{-1}$ e a saída de 2,3 mg.L $\mathrm{L}^{-1}$. A remoção de coliformes foi da ordem de $1 \log$, sendo que a entrada foi $1,3.10^{5}$ organismos e a saída de $3,10^{4}$ organismos. Cabe apontar que a média da carreira de filtração para essas condições foi de 4 horas e o custo estimado para a filtração de esgoto secundário foi calculado em $\mathrm{R} \$ 0,139$ por metro cúbico.

Li et al (2012) estudaram o uso de filtros rápidos de areia para o tratamento de efluente. Esse efluente era proveniente de estação de esgoto que utilizava no tratamento secundário os processos: anaeróbio, aeróbio, anóxico e decantação. O meio filtrante era formado por 1,5 m de areia de quartzo, com grãos de tamanho efetivo entre 0,8 a $1,5 \mathrm{~mm}$, e a taxa de aplicação superficial foi variada de 135 a $240 \mathrm{~m}^{3} \cdot \mathrm{m}^{-2} \cdot \mathrm{dia}^{-1}$. Os autores constataram que o acréscimo no efeito de remoção de coliformes devido a alteração da dose de coagulante é mínima. 
Hamoda e Al-Ghusain (2004) utilizaram filtro de areia para avaliar sua viabilidade como pós-tratamento em três estações de esgoto do Kuwait. Esse filtro possuía meio filtrante formado por camada de areia de 0,6 m de altura e camada suporte de pedregulho de 0,4 $\mathrm{m}$ de altura. $\mathrm{O}$ afluente era aplicado a taxa de $120 \mathrm{~m}^{3} \cdot \mathrm{m}^{-2} \cdot \mathrm{dia}^{-1}$ (sem aplicação de coagulantes). As estações possuíam como tratamento secundário sistema de lodos ativados, sendo que em Rikka e Jahra os sistemas que utilizavam aeração prolongada e em Ardiya o sistema era convencional. Os resultados da caracterização do filtrado foram piores em Ardiya e o autor atribuiu isso ao fato do sistema convencional de lodos ativados receber maior sobrecarga hidráulica do que o sistema de aeração prolongada. Na Tabela 3.6 são apresentados os resultados da pesquisa.

Tabela 3.6: Pós-tratamento por filtro de areia rápido no Kuwait (Hamoda e Al-Ghusain, 2004).

\begin{tabular}{|c|c|c|c|c|}
\hline & $\begin{array}{c}\text { SST entrada } \\
\left(\mathrm{mg} . \mathrm{L}^{-1}\right)\end{array}$ & $\begin{array}{c}\text { SST saída } \\
\left(\mathrm{mg.L}^{-1}\right)\end{array}$ & $\begin{array}{c}\text { DQO entrada } \\
\left(\mathrm{mg.L}^{-1}\right)\end{array}$ & $\begin{array}{c}\text { DQO saída } \\
\left(\mathrm{mg.L}^{-1}\right)\end{array}$ \\
\hline Ardiya & 13,9 & 9,2 & 62,5 & 49,4 \\
\hline Rikka & 8,5 & 4,9 & 30,6 & 25,8 \\
\hline Jahra & 11,5 & 5,2 & 51,9 & 32,6 \\
\hline
\end{tabular}

Considerando as proposições relatadas neste item, para águas residuárias, a concepção de sistema de filtração rápida que melhor atende às características relacionadas com elevado teor de sólidos suspensos e longa carreira de filtração é aquela que envolve leito com maior espessura (permitindo a filtração em profundidade), tamanho específico dos grãos entre $(0,9$ a 2,0 mm) e coeficiente de não-uniformidade menor que 1,5. Contudo, Campos (2014), por informação pessoal, recomenda fortemente o uso de leitos com coeficiente de não-uniformidade inferior a 1,2 . 
Página intencionalmente deixada em branco. 


\section{MATERIAIS E MÉTODOS}

\subsection{Considerações iniciais}

Na Figura 4.1 constam, esquematicamente, a distribuição do afluente ao reator, segundo critérios estabelecidos para reatores UASB, e o sistema com agitação por jatos, conforme proposto nesse trabalho. Em ambos os casos, é fator obrigatório a manutenção da manta de lodo, conforme prevalece em reatores anaeróbios de manta de lodo.

Um dos objetivos nessa pesquisa é a redução significativa do número de pontos de alimentação $\left(\mathrm{A} 1 \leq 4 \mathrm{~m}^{2}\right)$, utilizando um número expressivamente menor de bocais.

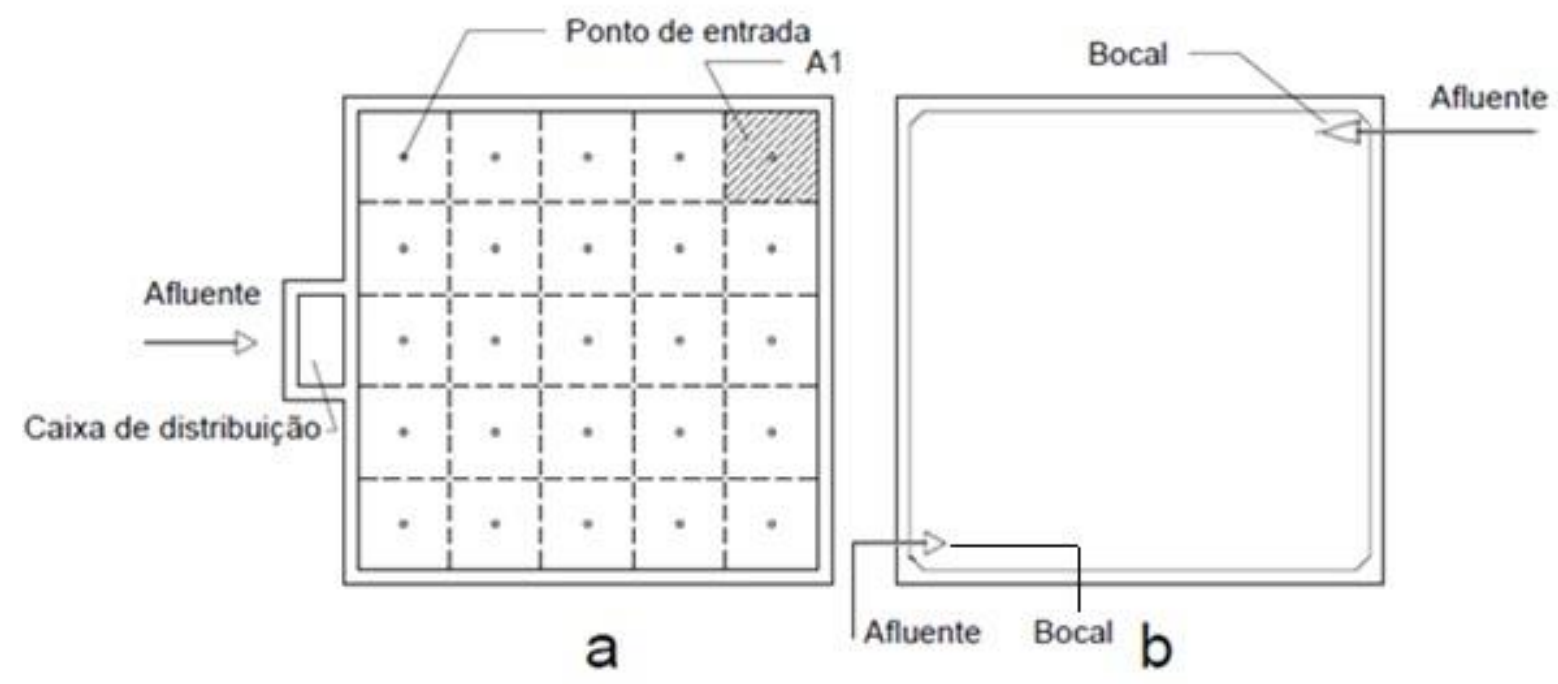

Figura 4.1: Comparação do sistema de alimentação: (a) reator convencional (Agricultural University Of Wageningen, 1994); (b) sistema empregando jatos misturadores.

Além da nova forma de alimentação, buscou-se operar o reator sem o sistema separador trifásico, substituindo-o por um decantador de alta taxa, instalado após a zona de reação. Para mostrar a viabilidade dessa nova concepção de reator anaeróbio de manta de lodo, a parte experimental foi estruturada inicialmente em escala laboratorial e posteriormente foram construídas duas unidades piloto.

Neste item serão detalhados os procedimentos experimentais, que foram contemplados em três fases principais. A primeira fase foi realizada em escala de bancada com o intuito de 
alcançar a intensidade necessária para uma agitação propícia, bem como o entendimento do comportamento do lodo anaeróbio sob tal agitação.

Já a segunda fase envolveu testes em reator em escala piloto com volume de 2,69 $\mathrm{m}^{3} \mathrm{e}$ construído em acrílico. A escolha desse tipo de material objetivou visualizar as características do jato proveniente do bocal, o comportamento da manta de lodo sob esse tipo de agitação, e a viabilidade do uso de bocais para proporcionar a agitação.

$\mathrm{Na}$ terceira fase foram realizados testes em reator com volume de $20,8 \mathrm{~m}^{3}$, para avaliar o comportamento da manta de lodo sob agitação em reator com altura $(5,3 \mathrm{~m})$ semelhante às alturas praticadas nos reatores de escala real. Além disso, foram avaliadas a eficiência e viabilidade do uso de filtração rápida como pós-tratamento ao reator anaeróbio.

A segunda e a terceira fases envolveram testes em reator piloto, utilizando esgoto sanitário, e operados na Estação de Tratamento de Esgoto do campus 1 da USP em São Carlos — ver Figura 4.2. Na Figura 4.3 está exposto o fluxograma com cada fase da pesquisa.

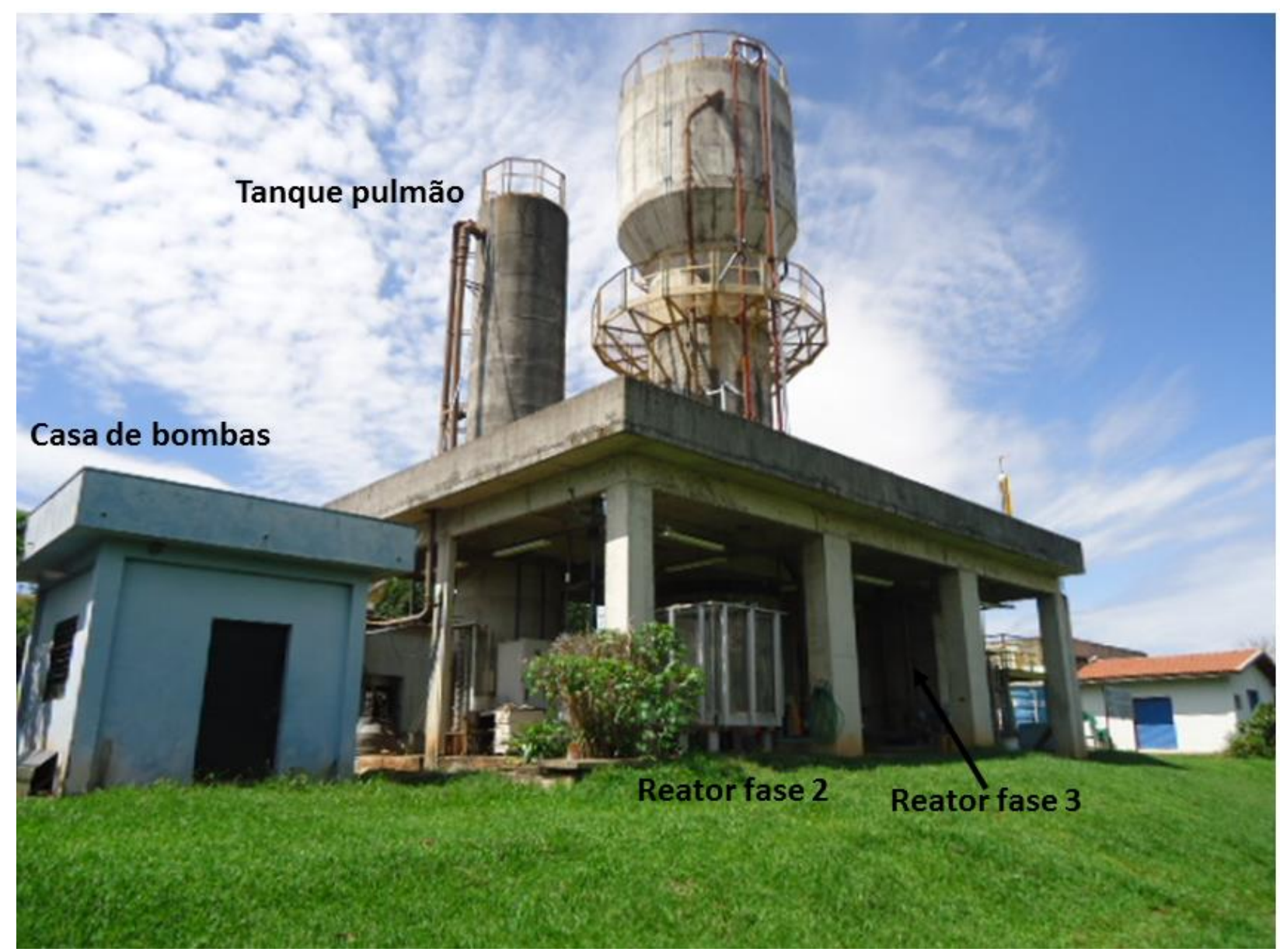

Figura 4.2: Estação de Tratamento de Esgoto da EESC/USP, local de desenvolvimento de parte desta pesquisa (fases 2 e 3 ). 


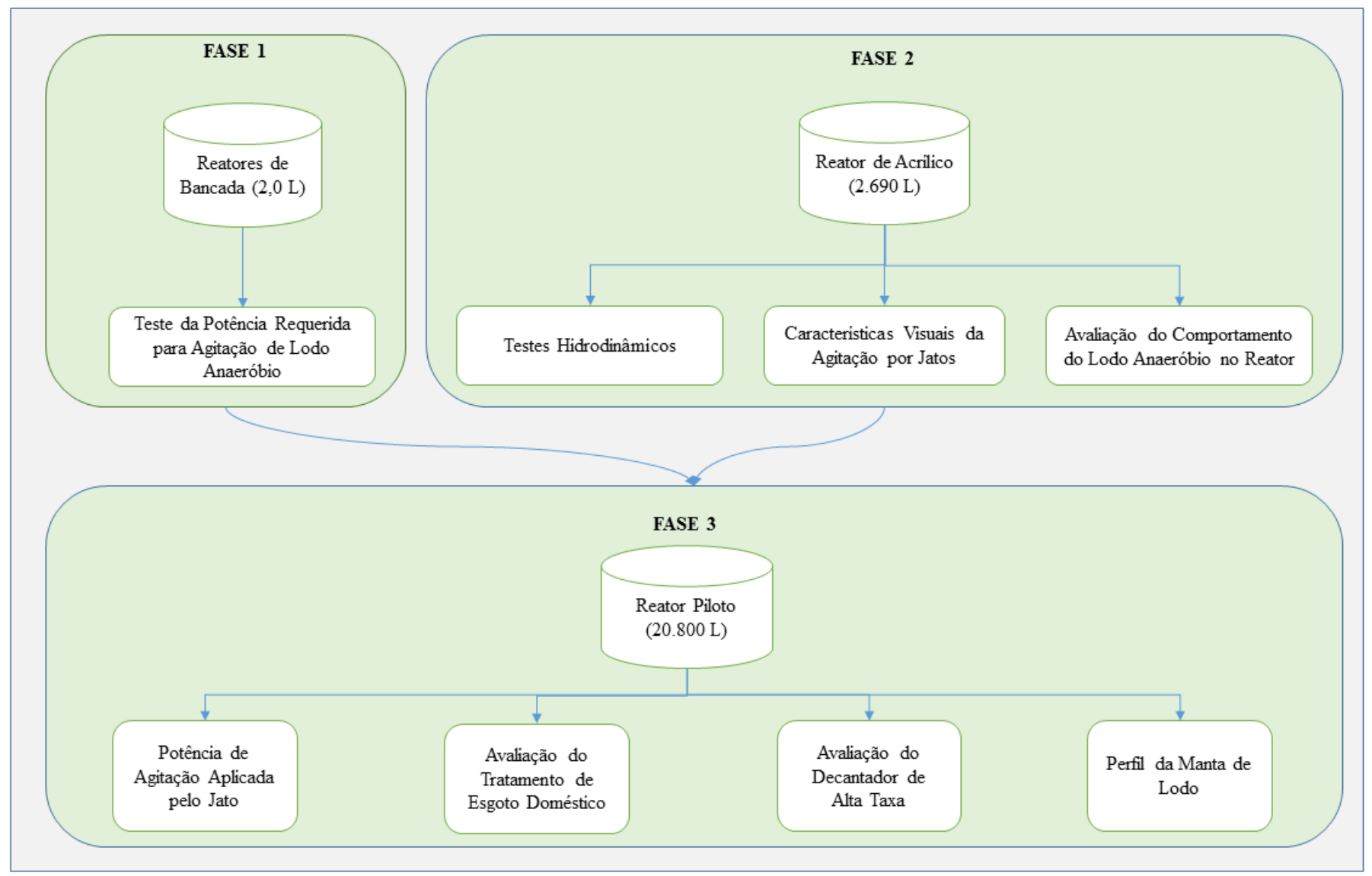

Figura 4.3: Fluxograma das fases experimentais.

\subsection{Fase 1: Agitação em reatores de bancada}

A primeira fase da pesquisa foi realizada em escala de bancada visando avaliar a energia necessária para promover agitação e o tratamento efetuado pelos reatores agitados.

Para a execução do experimento foi utilizado um dispositivo com agitação controlada (jar-test - aparelho geralmente utilizado em ensaios de floculação), com jarros adaptados para recebimento de esgoto sanitário contínuo, para funcionarem como reatores biológicos. A possibilidade da variação na rotação dos misturadores foi determinante para a escolha desse aparelho, pois a velocidade de rotação é facilmente ajustada no display do aparelho. A velocidade dos misturadores era fornecida em rotações por minuto (rpm), e associadas aos valores de gradiente de velocidade $(G)$ aplicado.

Dessa forma, procedeu-se com a introdução de um sistema de alimentação pelo fundo do reator. Esse sistema era constituído por: bomba dosadora, que recalcava esgoto sanitário de 
um reservatório (com esgoto bruto peneirado) que era utilizado concomitantemente com outras pesquisas; tubos de alimentação em silicone de $6 \mathrm{~mm}$ de diâmetro; e tubos de vidro que direcionavam o afluente para a porção inferior central do reator. Para a coleta do efluente tratado, foram instalados tubos de silicone na parte superior do reator. Esse sistema está ilustrado pela Figura 4.4.

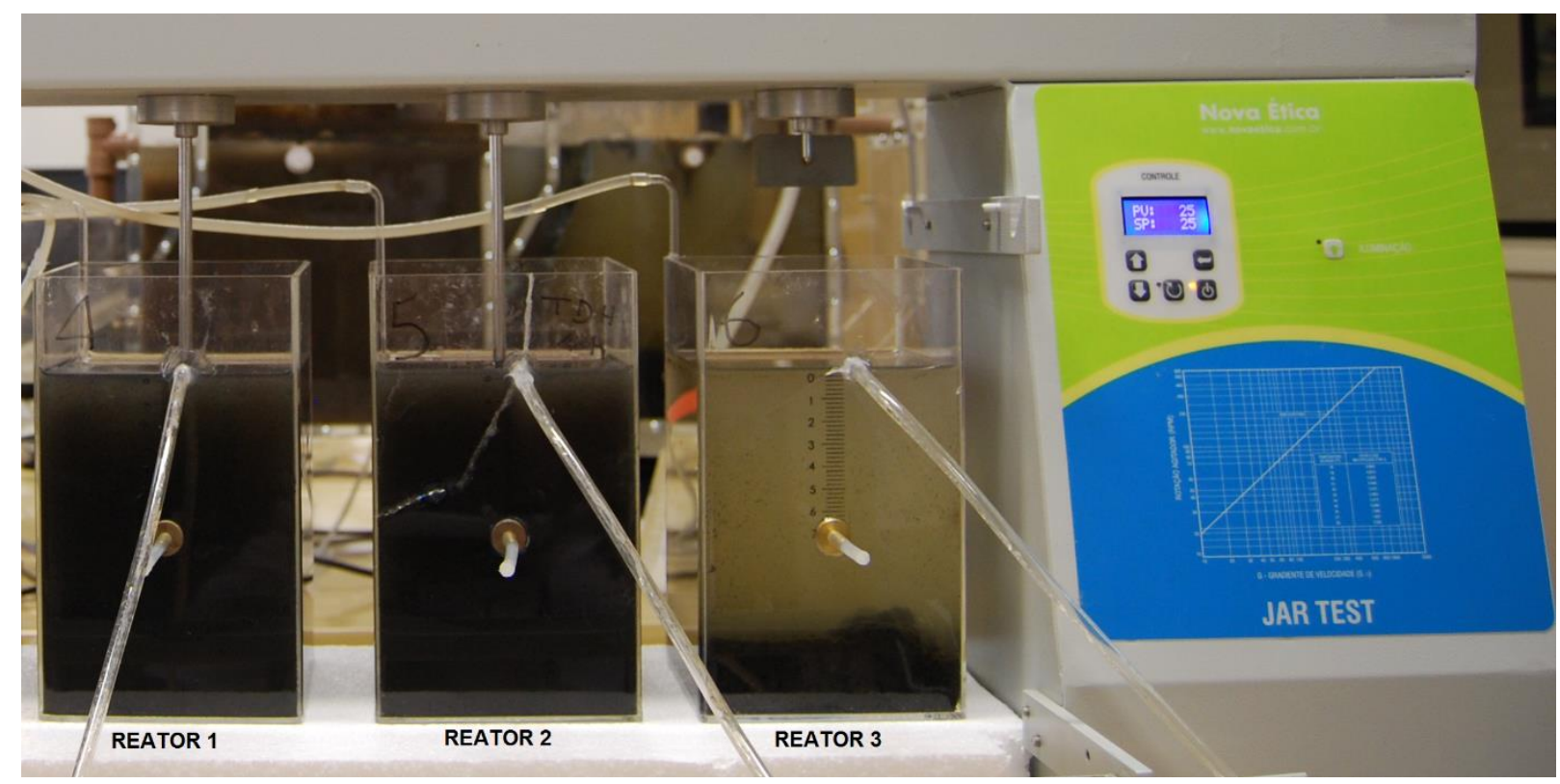

Figura 4.4: Reatores de bancada onde foi avaliada a energia de agitação. (1 e 2) reatores agitados; (3) reator de controle para avaliar perda de biomassa somente por arraste.

Nos testes de agitação, cada reator foi inoculado com 0,8 1 de lodo anaeróbio a fim de ocupar $40 \%$ do volume total (volume correspondente à zona de reação em reatores UASB). Enquanto eram agitados, os recipientes eram alimentados constantemente com esgoto sanitário.

Variou-se o gradiente de velocidade de 0 a $80 \mathrm{~s}^{-1}$ para determinar qual o valor necessário para promover diferentes cenários para a suspensão do lodo de fundo. Após o lodo estar completamente suspenso o valor de $\mathrm{G}$ era progressivamente diminuído, até a formação de interface isenta de lodo no topo dos recipientes (estratificação). Nesse instante era possível diferenciar a manta de lodo e determinar a energia requerida durante a operação contínua de reatores.

Além dos ensaios de agitação, os reatores de bancada foram alimentados continuamente com esgoto, por 37 dias, para verificação da remoção da matéria orgânica em termos da DQO bruta. Os reatores 1 e 2 foram agitados com um valor médio de $G=20 \mathrm{~s}^{-1}$, enquanto o reator 3 foi mantido sem agitação. O reator 1 foi operado com TDH de 4 horas, enquanto os reatores 2 
e 3 foram operados com TDH de 8 horas. O experimento foi realizado em sala climatizada com temperatura média de $20^{\circ} \mathrm{C}$. As amostras de DQO foram coletadas semanalmente, em dois pontos distintos: no reservatório de esgoto bruto e nos tubos de coleta do efluente tratado.

\subsection{Fase 2: Estudo de reator piloto agitado por jatos}

\subsubsection{Generalidades}

Esta fase da pesquisa objetivou avaliar se o bocal proposto gerava jato com características semelhantes às mencionadas na literatura, provocando, consequentemente, uma boa mistura entre esgoto afluente e biomassa. Somado a isto, foi analisado se seria possível ter flexibilidade operacional para se manter estruturada uma manta de lodo típica.

\subsubsection{Bocais utilizados na pesquisa}

Em vista de se obter menor perda de carga localizada e, consequentemente, alcançar melhor efeito na mistura, os bocais foram utilizados em detrimento ao uso de extremidades livres ou tubulações perfuradas.

Devido à importância conceitual de realizar a mistura através de jatos, buscou-se a melhor configuração possível, respeitando viabilidades práticas para futura aplicação em campo, com o intuito de se obter a menor perda de carga possível, aliada a uma velocidade do jato satisfatória na saída.

Analisando os dados de bibliografia, apresentado no item 3.4.3, verificou-se que os melhores tipos de bocais para mistura são os cônicos, descartando o uso de bocais cilíndricos. Em relação à característica do esgoto sanitário, que frequentemente pode ter sólidos de dimensões significativas, não retidos nos tratamentos preliminares, foi previsto o uso de bocais que pudessem minimizar problemas com entupimentos. 
Sendo assim, optou-se pela usinagem de peças cuja forma e dimensões fossem fiéis aos valores de projeto, selecionando apenas uma geometria em vista da praticidade e custos inerentes. Devido à maior frequência de uso em estudos, além da compatibilidade com a pesquisa, adotou-se o uso de bocais cônicos divergentes.

Os parâmetros utilizados para a confecção dos bocais foram: a vazão de descarga desejada; o diâmetro da seção contraída; a velocidade na saída do bocal; a energia dissipada pelo jato; e o ângulo de divergência do bocal - maiores detalhes são dados no item 4.4.4.1. O formato do bocal utilizado nessa pesquisa é apresentado na Figura 4.5.

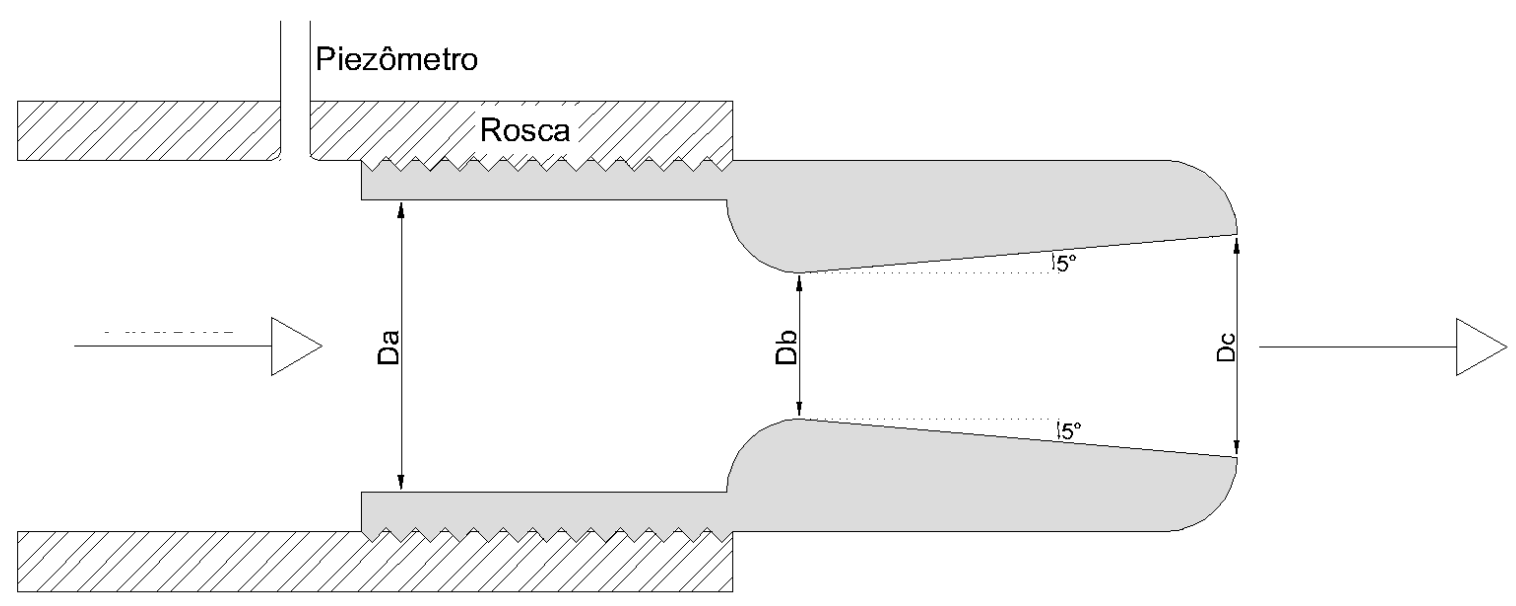

Figura 4.5: Bocal utilizado para promover mistura nos reatores.

$\mathrm{Na}$ Tabela 4.1 são indicadas as características dos bocais que foram utilizados para criar os jatos intermitentes no reator da fase 2 e no reator anaeróbio da fase 3.

Tabela 4.1: Dimensões dos bocais utilizados nos dois reatores experimentais.

\begin{tabular}{lcc}
\hline & (I) reator piloto fase 2 & (II) reator piloto fase 3 \\
\hline Volume reator & $2,69 \mathrm{~m}^{\mathbf{3}}$ & $17,8 \mathrm{~m}^{3}$ \\
Da (Diâmetro a) & $14 \mathrm{~mm}$ & $84 \mathrm{~mm}$ \\
Db (Diâmetro b) & $7 \mathrm{~mm}$ & $42 \mathrm{~mm}$ \\
Dc (Diâmetro c) & $10,67 \mathrm{~mm}$ & $64,05 \mathrm{~mm}$ \\
Ângulo de divergência & $5^{\circ}$ & $5^{\circ}$ \\
\hline
\end{tabular}




\subsubsection{Instalação experimental}

Um tanque de acrílico de volume 2,69 $\mathrm{m}^{3}$ (1,75 m x 1,75 m x 0,88 m) foi utilizado para a avaliação dos sistemas propostos na concepção desta pesquisa: agitação proporcionada pela adição do bocal na tubulação de entrada de um reator e alimentação intermitente do sistema.

Esse reator foi instalado na Estação de Tratamento de Esgotos do Campus 1 da USP/São Carlos, e ligado a duas linhas de alimentação. A primeira linha recalcava o esgoto afluente à ETE do Campus universitário; a segunda linha bombeava água de abastecimento para realização dos testes hidrodinâmicos com traçador e para avaliação da capacidade de mistura. Este tanque está ilustrado na Figura 4.6. Nessa instalação foram instalados 4 bocais, com as dimensões especificadas na coluna I, da Tabela 4.1 .

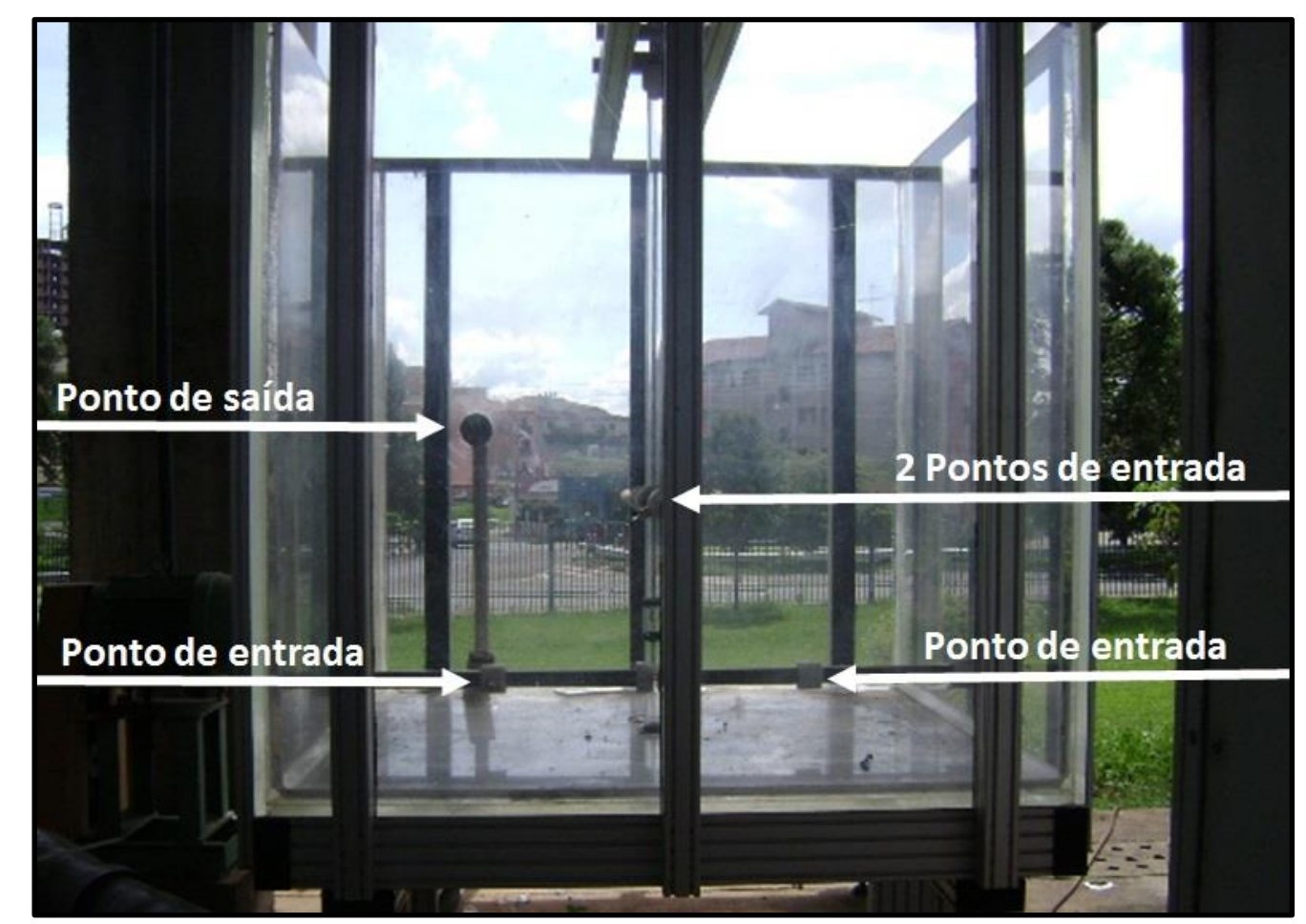

Figura 4.6: Tanque de acrílico para testes preliminares com os bocais submersos.

Um dos parâmetros que deve ser considerado nos projetos de reatores é o tempo de detenção hidráulica, possibilitando que o efluente permaneça no reator período suficiente para que ocorra degradação dos poluentes. Para obtenção da energia necessária para agitação da manta de lodo por jatos a vazão necessária é elevada, e não poderia ser obtida devido à limitação imposta pelo TDH para operação contínua do reator. Para resolver essa questão optou-se pela 
utilização de um reservatório, com saída acoplada a uma válvula automática, que armazenava o afluente por 5 minutos e liberava grande volume de efluente em curto espaço de tempo (1 minuto), proporcionando a energia suficiente para a mistura desejada. Os dados utilizados no dimensionamento desse reservatório e dos bocais são apresentados na Tabela 4.2. O reservatório e a válvula de abertura automática podem ser visualizados na Figura 4.7.

Tabela 4.2: Dimensionamento do reator utilizado na fase 2 da pesquisa.

\begin{tabular}{|c|c|c|}
\hline & $\begin{array}{c}\text { Valores de } \\
\text { projeto }\end{array}$ & $\begin{array}{c}\text { Valores } \\
\text { reais }\end{array}$ \\
\hline Volume do reator $\left(\mathrm{m}^{3}\right)$ & 2,69 & 2,69 \\
\hline TDH & $8 \mathrm{~h}$ & $7,47 \mathrm{~h}$ \\
\hline Vazão $\left(1 . h^{-1}\right)$ & 336,25 & 360,00 \\
\hline Vazão (1.min $\left.{ }^{-1}\right)$ & 5,6 & 6,0 \\
\hline $\begin{array}{l}\text { Volume do reservatório (para armazenar o afluente } \\
\text { por cinco minutos - l) }\end{array}$ & 33,6 & $36,0^{(3)}$ \\
\hline Número de bocais adotado & 4 & 4 \\
\hline Vazão por bocal $\left(\mathrm{m}^{3} \cdot \mathrm{s}^{-1}\right)$ & 0,00014 & 0,00015 \\
\hline Altura manométrica do reservatório (m) & 1,0 & $2,0^{(4)}$ \\
\hline Coeficiente de descarga & 0,8 & $0,82^{(5)}$ \\
\hline Diâmetro da seção contraída de cada bocal $(\mathbf{m m})^{(1)}$ & 7 & 7 \\
\hline Gradiente de velocidade $\left(\mathbf{s}^{-1}\right)^{(2)}$ & 14,4 & - \\
\hline
\end{tabular}

(1) Utilizando-se a lei dos orifícios: $Q=C D \cdot A b \cdot \sqrt{2 \cdot g \cdot h}$

(2) Utilizando-se: $G=\sqrt{\frac{(\gamma * Q * h}{\mu * V o l}}$

(3) A construção do reservatório resultou em volume maior que o de projeto, o que acarretou em pequeno aumento da vazão aplicada por bocal e redução do TDH.

(4) O tanque de acrílico utilizado na pesquisa possuía características estruturais que impossibilitaram a implantação do reservatório a uma menor altura.

(5) Coeficiente do bocal foi medido na fase 3 (item 5.4.2). 


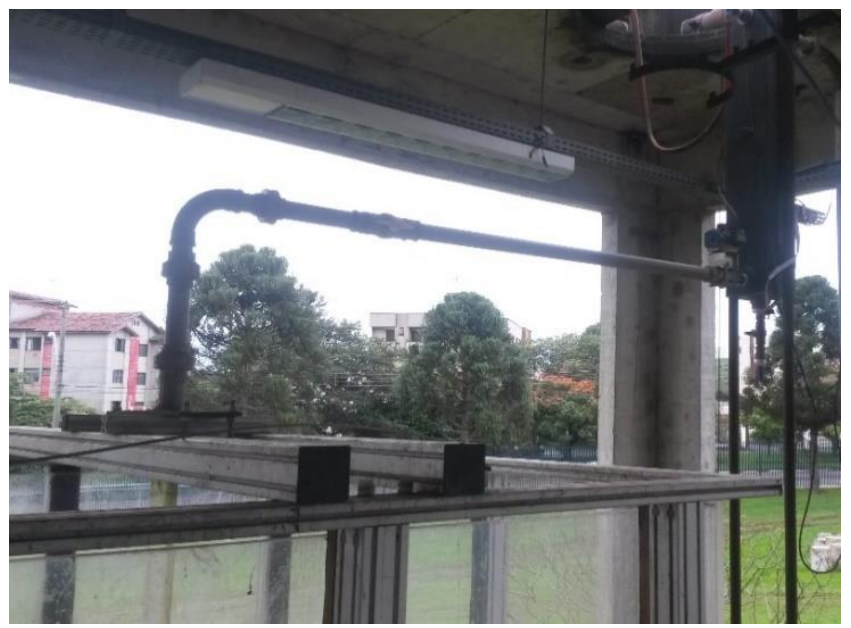

Figura 4.7: Reservatório elevado e válvula de abertura rápida utilizados para gerar alimentação do reator por jatos intermitentes.

A alimentação do reator, após o reservatório, era feita por tubulação de diâmetro 1 1/2" disposta na região central do tanque, que dividia-se em quatro tubos de alturas distintas (os dois primeiros tubos ficavam a $15 \mathrm{~cm}$ do fundo do reator e os outros dois tubos a $50 \mathrm{~cm}$ do fundo). Os bocais foram instalados nesses tubos, como pode ser visto na Figura 4.8.

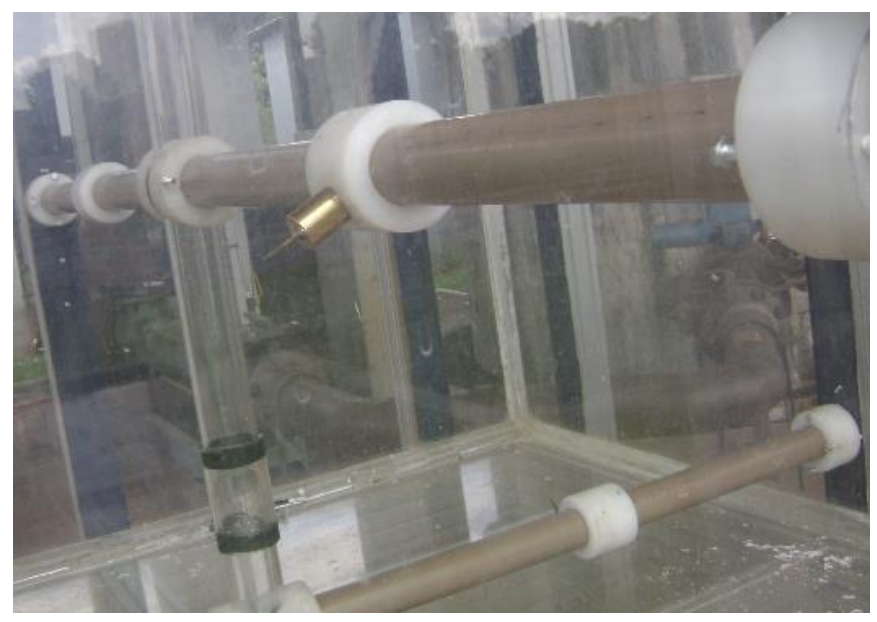

Figura 4.8: Detalhe da instalação dos bocais no reator.

\subsubsection{Ensaios realizados}

Para determinação do tempo de mistura do reator foi aplicado um pulso com rodamina $\beta$ dissolvida na água e avaliou-se o tempo necessário para o traçador se espalhar no volume do 
reator na totalidade. Para tal, foram tiradas uma sequência de fotografias temporizadas, englobando os dois lados do reator, para a visualização lateral e frontal das tubulações de entrada superiores e inferiores, e, observação da configuração geométrica dos jatos.

O segundo teste realizado no reator foi o hidrodinâmico. A realização de ensaios hidrodinâmicos para o reator proposto foi impulsionada por dois motivos: o primeiro foi estimar o tempo de detenção hidráulica real para o esgoto sanitário no reator e o segundo foi analisar o tipo de escoamento predominantemente gerado pela entrada do fluido mediante jatos turbulentos.

Para a execução dos ensaios hidrodinâmicos o traçador escolhido foi o cloreto de sódio $(\mathrm{NaCl})$, um traçador de uso comum nesse tipo de ensaio.

O traçador foi injetado no reator na forma de pulso único. Escolheu-se esse tipo de injeção pela simplicidade na aplicação e por não ocorrer reatividade entre traçador e fluido do reator. Ademais, a injeção de traçador por pulso necessita apenas que se conheça a vazão do reator e a massa de traçador aplicada para o levantamento da curva de distribuição de tempo de residência (DTR). Então, mede-se o tempo necessário para que esse fluido contendo o traçador atravesse o interior do reator. Como as parcelas do fluido tomam diferentes rotas, ocorrem diferentes tempos de permanência no reator. Assim, é obtida na saída do reator diferentes concentrações de traçador ao longo do tempo - conhecido também como teste de estímulo e resposta. Após obter as curvas de concentração dos traçadores, pode-se aplicar os modelos uniparamétricos apresentados por Levenspiel (2000).

Para determinação da quantidade de $\mathrm{NaCl}$ a ser aplicado no reator de acrílico, a principal preocupação foi aplicar massa que não extrapolasse o limite de solubilidade do sal na água, para que não houvesse no pulso de entrada partículas não dissolvidas. Dessa forma, foi aplicado uma solução, de $3 \mathrm{~kg}$ de sal para 361 de água. Esse pulso teve duração de 1 minuto, que é o tempo de descarga do reservatório elevado.

No primeiro ensaio adotou-se tempo de detenção hidráulica teórico (TDH) para o reator de 6,25 horas. As amostras de concentração salina foram coletadas durante 19 horas após a aplicação, para ocorrer tempo de amostragem equivalente a três vezes o tempo de detenção hidráulico adotado.

A amostragem da concentração de $\mathrm{NaCl}$ ocorreu a cada 3 minutos através da medida da condutividade com o auxílio de dois equipamentos: a Calculator Based Laboratory (CBL) e a calculadora TI-89, ambos fabricados pela Texas Instruments $\bigodot$. O CBL funciona como coletor de dados que pode ser acoplado a diversos sensores. Esses sensores passam a emitir resposta 
quando o software datamate da Vernier@ (que deve ser instalado na TI-89) é iniciado através da TI-89 acoplada ao CBL.

O sensor identifica valores de tensão elétrica, que devem ser convertidos para valores de concentração salina correspondente. Para a calibração do sensor, o software datamate precisa de duas amostras de concentração salina conhecida.

Foram usados para a calibração do sensor de condutividade água bruta retirada do reator (0 mg. $\mathrm{l}^{-1}$ de sal) e a uma solução salina de $8.220 \mathrm{mg} . \mathrm{l}^{-1}$. O reator foi operado com TDH igual a 6,25 h e foi adicionado ao reservatório de alimentação (36 1) $3 \mathrm{~kg}$ de sal.

No segundo ensaio hidrodinâmico adotou-se tempo de detenção hidráulica teórico (TDH) para o reator de 4,2 horas, e demais condições idênticas às do primeiro ensaio.

Ainda foram realizados ensaios de tratamento de esgoto sanitário pelo sistema. Para isso o reator foi inoculado com lodo anaeróbio proveniente do reator UASB da Estação de Tratamento de Esgoto do município de São Carlos (ETE Monjolinho).

A fim de se realizar o monitoramento do tratamento, amostras foram coletadas no reservatório elevado que alimentava o reator, e na saída do reator, com auxílio do amostrador automático ISCO 6700. O amostrador foi programado para realizar coletas a cada 4 horas, totalizando amostra composta de 24 horas. As variáveis utilizadas no monitoramento do sistema foram a DQO da amostra bruta e filtrada, a série de sólidos e o $\mathrm{pH}$.

Durante o período de monitoramento foram adotadas diversas formas de operação como alimentação contínua e intermitente; tempo de detenção hidráulica de 4 a 12 horas; operação com e sem retorno de lodo do decantador.

\subsection{Fase 3: Sistema piloto de manta de lodo}

\subsubsection{Introdução}

Os resultados dos ensaios preliminares (agitação da manta de lodo e viabilidade do uso de bocais para promover essa agitação) forneceram informações suficientes para ser projetado um sistema de agitação por jatos intermitentes em reator anaeróbio de manta de lodo em escala piloto. Esse sistema foi composto por um reator anaeróbio com volume de reação de $17,8 \mathrm{~m}^{3}$, 
e unidade de remoção de sólidos de volume $3,0 \mathrm{~m}^{3}$, totalizando um sistema com $20,8 \mathrm{~m}^{3}$ de volume. Além disso foi realizado o pós-tratamento do efluente em sistema de filtração rápida em areia.

A fase principal do trabalho, realizada no reator piloto de manta de lodo, fase 3, foi dividida em duas etapas: de ajustes iniciais e operacional. Na etapa de ajustes, tentou-se manter o sistema em equilíbrio (especialmente para a manutenção da manta de lodo). Essa dificuldade adveio da completa inovação nos sistemas de alimentação e de separação das parcelas sólidas e líquidas do efluente, levando à uma rotina de operação baseada no empirismo. Na etapa de operação, observaram-se ótimos resultados em relação ao tratamento do esgoto sanitário e, em especial, do dispositivo de remoção de sólidos e do pós-tratamento em filtro de areia, uma vez que o equilíbrio almejado na etapa de ajustes pôde ser alcançado.

\subsubsection{Descrição geral do sistema experimental (reator anaeróbio + decantador)}

O sistema experimental que será descrito a seguir consiste no foco principal desta pesquisa, pois engloba os principais objetivos do trabalho: concepção de reator anaeróbio alimentado por jatos intermitentes, remoção de sólidos suspensos por decantação de alta taxa, pós-tratamento em filtro de areia.

O sistema experimental utilizado na fase 3 foi dividido em duas unidades. A primeira unidade é o reator, responsável pela digestão anaeróbia do efluente através da biomassa acumulada em seu interior e com volume de 17,8 $\mathrm{m}^{3}$. A segunda unidade é um decantador de alta taxa, de volume $3,0 \mathrm{~m}^{3}$ e que tem por finalidade a separação dos sólidos suspensos carreados pelo efluente. A separação entre o reator e o decantador laminar foi realizada em chapa de aço, que além de isolar as duas áreas, serviu de suporte para fixação do decantador. As duas unidades juntas totalizaram um sistema com $20,8 \mathrm{~m}^{3}$. Esse foi o volume utilizado para as determinações dos tempos de detenção hidráulica média do sistema.

A montagem deste sistema foi realizada utilizando a estrutura de um reator UASB existente na Estação de Esgoto da EESC/USP. As dimensões deste reator, que foi adaptado para a instalação do novo sistema, são 2,0 m x 2,0 m x 5,2 m (comprimento x largura x altura). Esse reator foi submetido à reforma, para remoção do sistema de distribuição de fundo e do sistema trifásico. 
O dimensionamento do sistema foi realizado a partir da vazão afluente ao sistema anaeróbio e do valor adotado do gradiente de velocidade proporcionado pelo jato na zona de digestão. Para obter tal gradiente, a vazão de descarga dos jatos foi 7 vezes superior à vazão afluente média, ou seja, o afluente era armazenado por 3 minutos e descarregado por 30 segundos, gerando uma alimentação intermitente com ciclos de 3 minutos e meio de duração. Na Tabela 4.2 são apresentados os critérios utilizados no dimensionamento do sistema.

Tabela 4.3: Dimensionamento do reator utilizado na fase 2 da pesquisa.

\begin{tabular}{|c|c|c|}
\hline & Valores de projeto & Valores reais ${ }^{(1)}$ \\
\hline Gradiente de velocidade $\left(\mathrm{s}^{-1}\right)$ & 20 & 16,6 \\
\hline Volume do sistema anaeróbio $\left(\mathrm{m}^{3}\right)$ & 20,8 & 20,8 \\
\hline Volume da zona de decantação $\left(\mathrm{m}^{3}\right)$ & 3,0 & 3,0 \\
\hline Volume da zona de reação $\left(\mathbf{m}^{3}\right)$ & 17,8 & 17,8 \\
\hline TDH & $8 \mathrm{~h}$ & $8 \mathrm{~h}$ \\
\hline Vazão afluente $\left(1 . h^{-1}\right)$ & 2600 & 2600 \\
\hline Vazão afluente (l.min $\left.{ }^{-1}\right)$ & 43,33 & 43,33 \\
\hline $\begin{array}{c}\text { Volume do reservatório (para armazenar o } \\
\text { afluente por três minutos - l) }\end{array}$ & 151,7 & 151,7 \\
\hline Número de bocais adotado & 1 & 1 \\
\hline Vazão no bocal durante a descarga $\left(\mathrm{m}^{3} \cdot \mathrm{s}^{-1}\right)$ & 0,005 & 0,005 \\
\hline Carga manométrica aplicada (m) & 1,42 & 0,98 \\
\hline Coeficiente de descarga & 0,8 & 0,82 \\
\hline $\begin{array}{l}\text { Diâmetro da seção contraída de cada bocal } \\
\qquad(\mathrm{mm})\end{array}$ & 39 & 42 \\
\hline
\end{tabular}

(1) O detalhamento dessas medidas está no item 4.4.4.1 e no item 5.4.2.

O sistema foi alimentado com esgoto sanitário proveniente do campus da EESC e dos bairros no entorno da Universidade. O esgoto sanitário passava por tratamento preliminar antes de ser bombeado a um tanque pulmão que atendia todas unidades de pesquisa instaladas na Estação de Tratamento. O tratamento preliminar consistia de uma grade grossa e de caixa de areia. Na Figura 4.9 é apresentado fluxograma com as unidades utilizadas no experimento. 


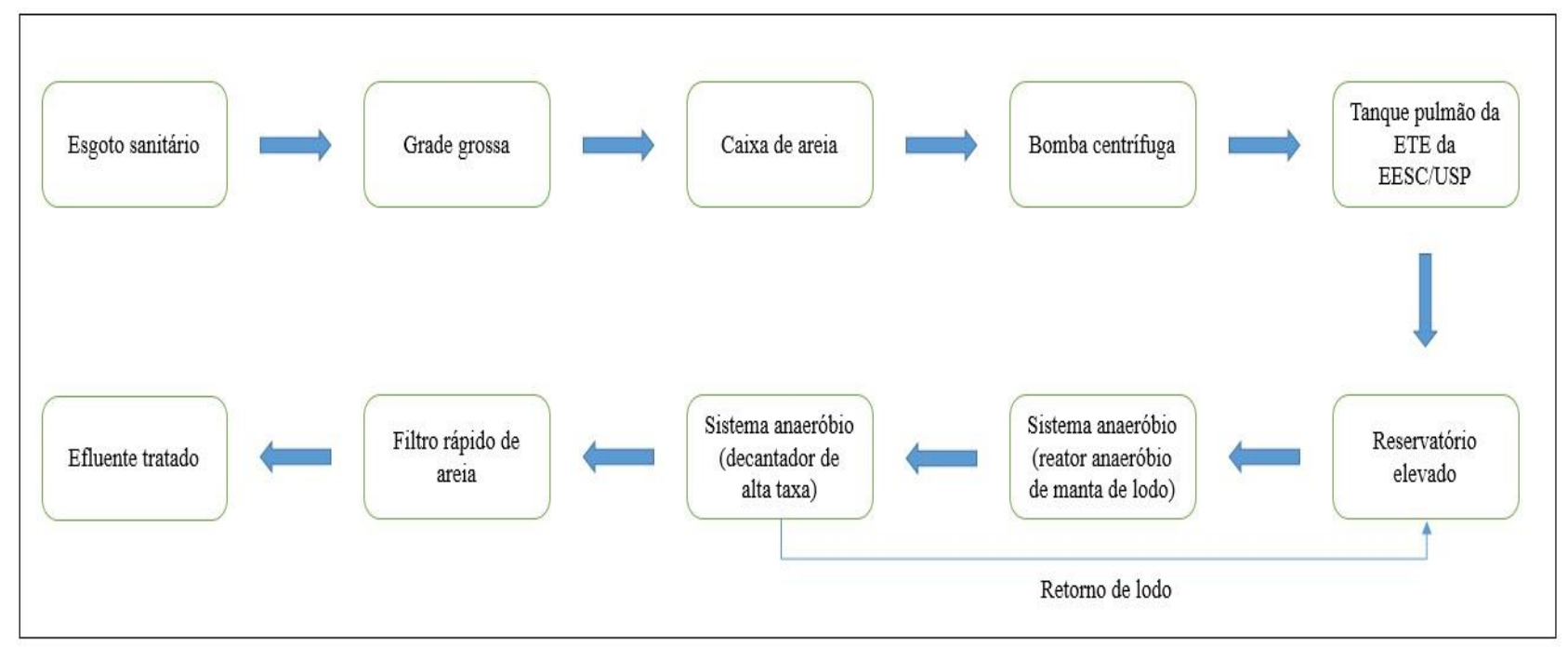

Figura 4.9: Fluxograma das unidades de tratamento utilizadas na terceira fase da pesquisa.

Um esquema com a estrutura do sistema experimental é apresentado na Figura 4.10, sendo destacados os componentes essenciais para o bom funcionamento do sistema proposto. Na Figura 4.11 é apresentado um esquema para ilustrar o posicionamento do sistema na Estação de Tratamento de Esgoto da EESC/USP.

Após o tanque pulmão, o esgoto era encaminhado até a primeira peça do sistema experimental que é o reservatório elevado. $\mathrm{O}$ esgoto era acumulado no reservatório elevado para atingir a carga hidráulica e a vazão de descarga necessárias para fornecer o valor de $G$ requerido à agitação.

A saída do reservatório era controlada por válvula automática acoplada a sensores de níveis (instalados no interior do reservatório). A válvula automática era acionada por atuador pneumático pois esse tipo de atuador promove a abertura e fechamento de válvula de forma imediata, em função do nível de esgoto na caixa. A energia total dissipada para mistura é empregada quando a válvula está completamente aberta. Dessa forma, a alimentação do reator era realizada por meio de pulsos (jatos intermitentes). A peça de numeração 3 na Figura 4.9, circundando a tubulação de entrada do reator, é um selo hídrico. Esse selo hídrico foi instalado pois a tubulação de entrada não podia ser fixada na tampa do sistema, com risco de ocorrer ruptura quando do fechamento da válvula automática e consequente vibração da tubulação. 


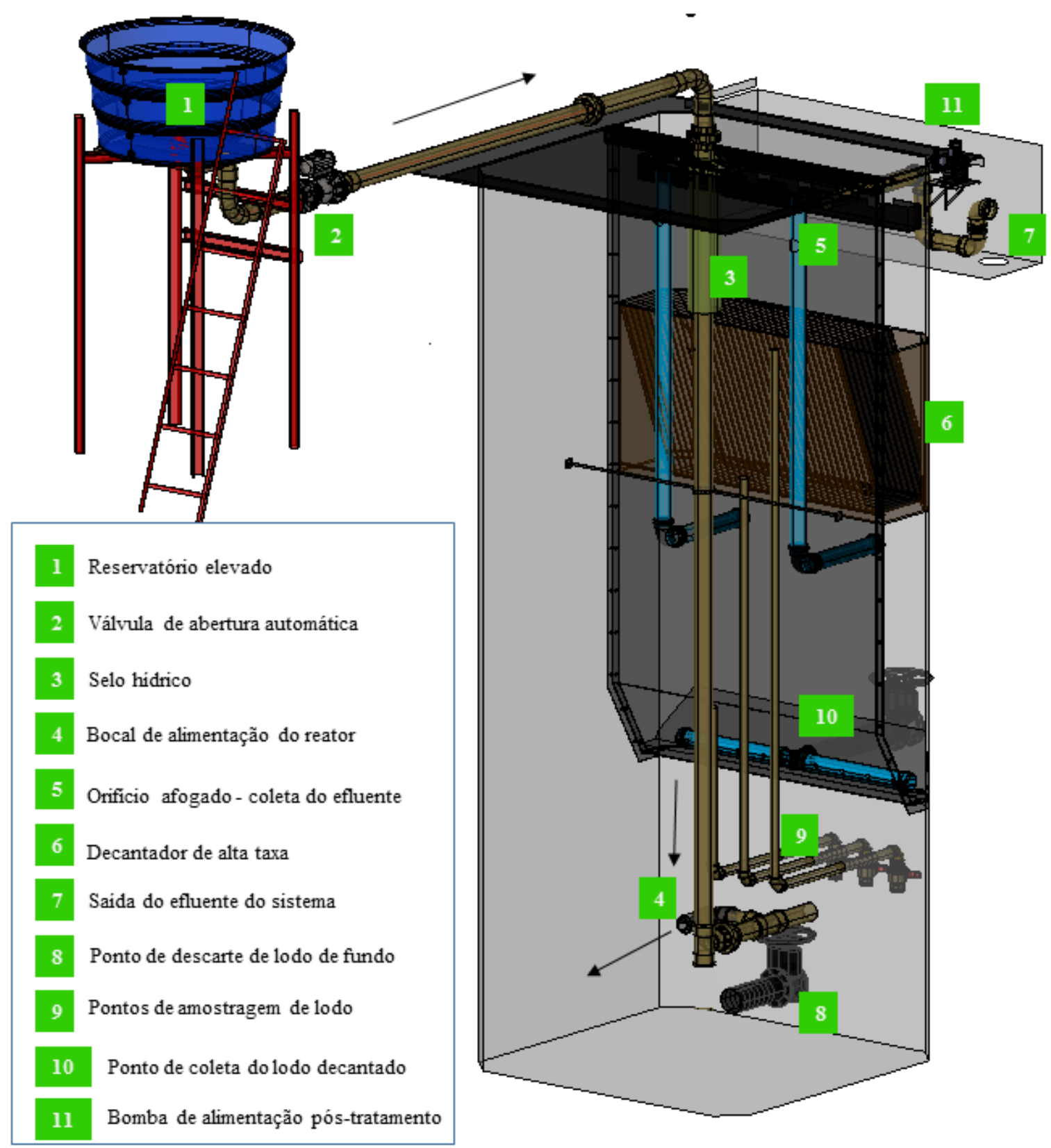

Obs: O lodo removido no ponto 10 é recalcado até o ponto 1, para recirculação.

Figura 4.10: Esquema do sistema piloto experimental. 


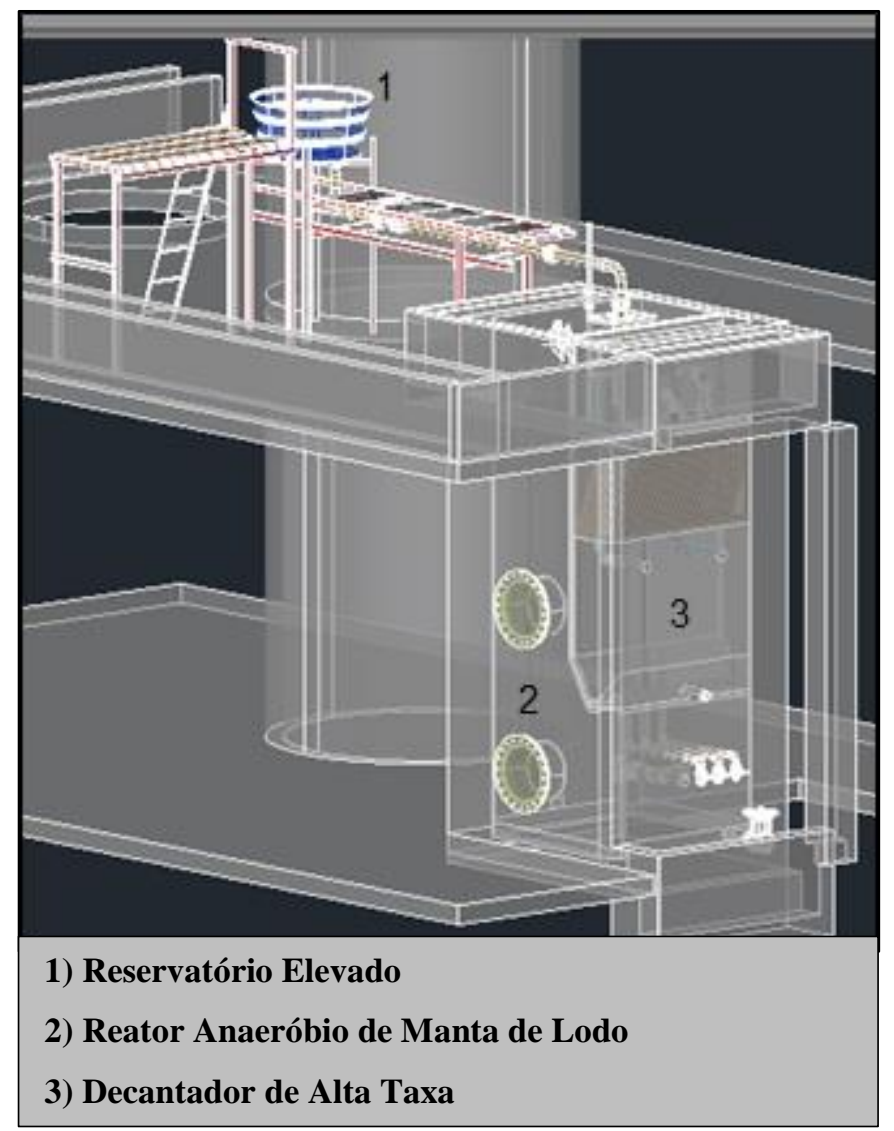

Figura 4.11: Esquema com visão geral do sistema piloto ante a Estação de Esgoto da USP.

A tubulação de alimentação encaminhava o afluente para próximo do fundo do sistema, que era inserido mediante uso de um único bocal (características na Tabela 4.1, item 4.3.2). O bocal foi disposto a $0,7 \mathrm{~m}$ do fundo e na posição horizontal. A escolha pela disposição horizontal do bocal se deu pela necessidade de agitação na parcela inferior do reator (onde encontra-se a manta de lodo), ao invés de se promover uma agitação que visasse a mistura completa do tanque. A Figura 3.15 apresentada no item 3.4.5 mostra a zona de influência de um bocal horizontal, que é a mesma região que se deseja promover agitação neste reator.

A coleta do efluente do reator foi realizada por dois tubos dotados de aberturas a $30 \mathrm{~cm}$ abaixo do nível d'água. Essa tubulação direcionava o escoamento para a porção inferior do decantador. Essas aberturas foram mantidas afogadas para evitar o aporte de escuma ao decantador.

Os pontos de amostragem foram distribuídos ao longo da altura do reator, e denominados por P0, P1, P2, P3. O P0 representa o ponto de coleta no fundo do reator, enquanto que P1, P2 e P3 representam os amostradores localizados a 2,0 m, 3,4 m e 4,2 $\mathrm{m}$ do fundo 
reator, respectivamente. Na Figura 4.10, o amostrador do fundo do reator está representado pelo número 8, e o número 9 indica os amostradores P1, P2 e P3.

A escolha pelo uso do decantador provido de placas paralelas, o decantador de alta taxa, se deu pela pequena área demandada por este sistema. Esse dispositivo é essencial para o bom funcionamento do reator piloto anaeróbio, pois, obrigatoriamente, o reator anaeróbio deveria dispor de dispositivo complementar para remover os sólidos suspensos arrastados no efluente. Esse sistema deve efetuar parte da função do separador trifásico dos reatores UASB, relacionada com a retenção de sólidos suspensos.

O projeto do decantador de alta taxa foi executado, considerando-se o fluxo em contracorrente (o escoamento flui em sentido contrário ao sentido de sedimentação dos sólidos), com coleta do efluente na região superior do reator. O acúmulo dos sólidos ocorria em câmara com volume total de $1.400 \mathrm{l}$, localizada imediatamente abaixo do ponto de entrada do decantador.

De acordo com Nahle (1991), a área de decantador é determinada pela taxa de carregamento por área $\left(\mathrm{m}^{3} \cdot \mathrm{m}^{-2} \cdot \mathrm{h}^{-1}\right)$ ou pela taxa de carregamento de sólidos $\left(\mathrm{kg} \mathrm{ST} \cdot \mathrm{m}^{-2} \cdot \mathrm{h}^{-1}\right)$.

A estrutura do decantador foi feita em madeira, utilizando como lamelas 35 placas de PVC, dispostas com ângulo de $70^{\circ}$ e espaçadas de $40 \mathrm{~mm}$ - essa disposição foi determinada conforme preconizado em AWWA (1999) para, simultaneamente, evitar arraste de sólidos e proporcionar autolimpeza (sedimentação das partículas) entre as placas. O decantador está ilustrado na Figura 4.12, e na Tabela 4.3 são apresentadas as condições operacionais do decantador.

Tabela 4.4: Condições operacionais do decantador de alta taxa.

\begin{tabular}{|c|c|c|}
\hline & TDH $=8 \mathrm{~h}$ & TDH $=12 \mathrm{~h}$ \\
\hline Número de placas & \multicolumn{2}{|c|}{35} \\
\hline Ângulo das placas & \multicolumn{2}{|c|}{$70^{\circ}$} \\
\hline Distância entre placas & \multicolumn{2}{|c|}{$40 \mathrm{~mm}$} \\
\hline Dimensões das placas & \multicolumn{2}{|c|}{$1,00 \mathrm{~m} \times 0,51 \mathrm{~m}$} \\
\hline Área coberta pelas placas & \multicolumn{2}{|c|}{$0,76 \mathrm{~m}^{2}$} \\
\hline $\begin{array}{l}\text { Taxa de aplicação } \\
\text { superficial }\end{array}$ & $81,7 \mathrm{~m}^{3} \cdot \mathrm{m}^{-2} \cdot \mathrm{dia}^{-1}$ & $54,5 \mathrm{~m}^{3} \cdot \mathrm{m}^{-2} \cdot \mathrm{dia}^{-1}$ \\
\hline $\begin{array}{c}\text { Velocidade de escoamento } \\
\text { entre placas }\end{array}$ & $3,75 \mathrm{~m} \cdot \mathrm{h}^{-1}$ & $2,50 \mathrm{~m} \cdot \mathrm{h}^{-1}$ \\
\hline
\end{tabular}



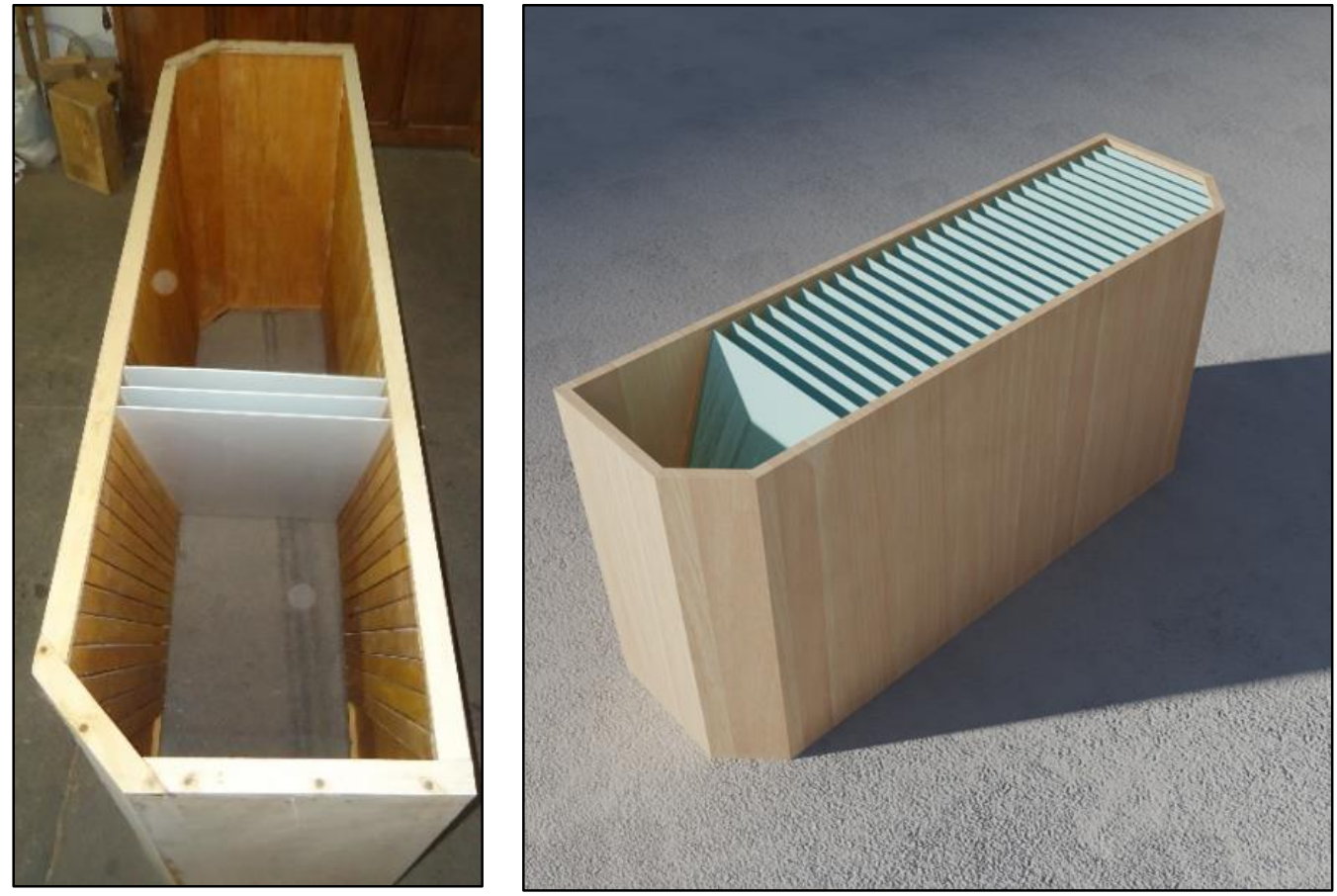

Figura 4.12: Detalhe e esquema do decantador de alta taxa instalado na saída do reator.

No fundo do decantador foi instalado sistema para recirculação e descarte de lodo. O sistema de recirculação era provido de bomba helicoidal que encaminhava o lodo para o reservatório elevado (responsável pela alimentação do reator). Essa recirculação foi realizada diariamente, pelo período de 15 minutos e vazão de $401 . \mathrm{min}^{-1}$. A Figura 4.13 mostra o sistema de descarte e retorno de lodo localizado no fundo do decantador. 


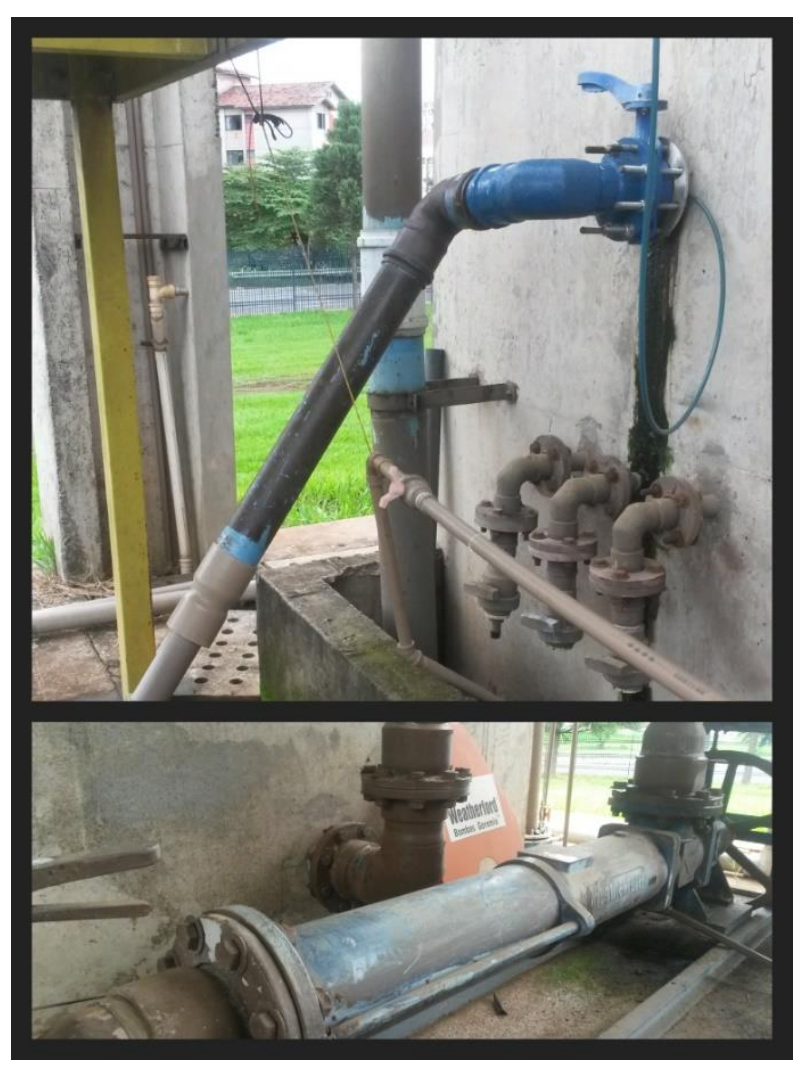

Figura 4.13: Sistema de descarte de lodo do fundo do decantador e retorno ao reservatório elevado.

\subsubsection{Procedimento experimental}

Para o início da operação do sistema foi realizada inoculação com $16 \mathrm{~m}^{3}$ de lodo anaeróbio proveniente dos reatores UASB da Estação Monjolinho (município de São Carlos atendimento a 220.000 habitantes). A partir de então o sistema foi operado durante 242 dias, divididos em três etapas. Na Tabela 4.4 é relacionada cada etapa com sua duração.

Tabela 4.5: Duração das etapas operacionais no sistema da fase 3.

\begin{tabular}{cc}
\hline Etapa & Duração (dias) \\
\hline 1 - Ajustes Iniciais & 150 \\
2 - Operação Contínua com TDH $=12 \mathrm{~h}$ & 79 \\
3 - Operação Contínua com TDH $=8 \mathrm{~h}$ & 13 \\
Operação Total & 242 \\
\hline
\end{tabular}


A primeira etapa foi denominada de ajustes iniciais. Nesta etapa foram testadas diferentes formas de operação, para avaliar qual rotina mais adequada para bom funcionamento do sistema. A vazão média afluente foi variada com intuito de obter os seguintes tempos de detenção hidráulica médio: 15 horas, 12 horas e 10 horas.

Além disso, variou-se a rotina de recirculação do lodo do decantador para o reator. Inicialmente não foi prevista recirculação diária, mas devido ao grande aporte de sólidos ao decantador foi necessário promover a recirculação todos os dias. Em um primeiro momento o volume recirculado diariamente foi de 200 litros e, posteriormente, de 600 litros. Para compensar as perdas de lodo do período, que era arrastado no efluente, foram realizadas adições de cargas biológicas (reinoculações). Foram adotadas estas variações operacionais na primeira etapa visando, principalmente, a manutenção da manta de lodo no reator.

A segunda etapa durou 79 dias, quando o o sistema foi operado continuamente com TDH médio de 12 horas e na terceira etapa avaliou-se brevemente a influência do aumento da vazão no sistema, que foi operado com TDH de 8 horas, por 13 dias.

Para a segunda e terceira etapas manteve-se a rotina de recirculação diária de 600 litros de lodo. A recirculação era realizada por bomba helicoidal pelo período de 15 minutos. Durante o período de recirculação a alimentação do sistema era interrompida, pois a vazão do lodo recirculado era superior a vazão de entrada e, somadas às vazões de entrada seriam muito elevadas podendo promover arraste de lodo. Na Tabela 4.5 são apresentadas as vazões de alimentação adotadas para cada condição operacional e para a recirculação.

Tabela 4.6: Condições operacionais para o sistema anaeróbio.

\begin{tabular}{|c|c|c|}
\hline $\begin{array}{l}\text { TDH médio } \\
\text { adotado }\end{array}$ & $\begin{array}{c}\text { Vazão Média Afluente } \\
\left(\mathbf{m}^{3} \cdot \mathbf{h}^{-1}\right)\end{array}$ & $\begin{array}{c}\text { Tempo de Enchimento do } \\
\text { Reservatório (tempo entre descargas) }\end{array}$ \\
\hline 15 horas & 1,387 & 4'45" \\
\hline 12 horas & 1,733 & $3^{\prime} 48^{\prime \prime}$ \\
\hline 10 horas & 2,080 & $3^{\prime} 10^{\prime \prime}$ \\
\hline 8 horas & 2,600 & $2,32^{\prime \prime}$ \\
\hline
\end{tabular}


4.4.4 Ensaios realizados na fase 3

\subsubsection{Determinação da agitação aplicada pelo jato}

Para determinação da carga manométrica aplicada ao bocal foi instalado um piezômetro na tubulação, imediatamente antes do bocal. O ponto de instalação do piezômetro é mostrado na Figura 4.14.

Os dados de carga manométrica medidos nesse piezômetro, juntamente com os dados de vazão no momento da descarga do jato, foram utilizados para determinação da potência de agitação (Equação 4.1) proporcionada ao reator. Destaca-se que foi utilizado um valor médio da energia da altura manométrica, pois a variação de altura no reservatório era pequena, da ordem de poucos centímetros, e também porque o tempo de descarga era muito curto (30 segundos). Os dados coletados foram referentes à operação do reator com TDH de 8 horas.

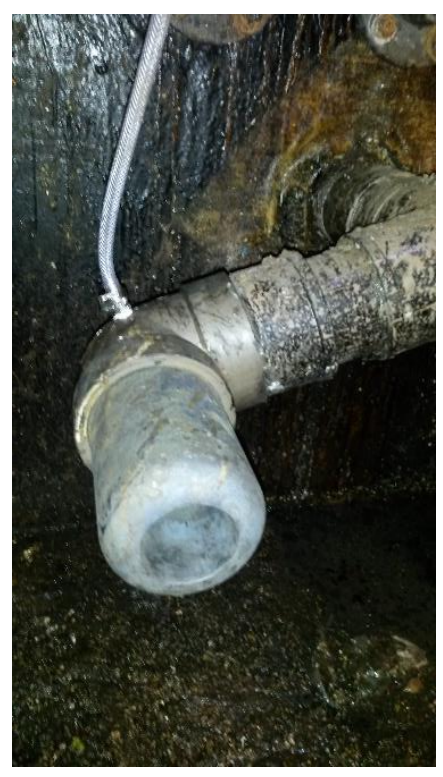

Figura 4.14: Detalhe do piezômetro instalado à montante do bocal na tubulação de alimentação.

A partir do cálculo da potência hidráulica do jato foi possível encontrar o gradiente de velocidade referente ao tempo de descarga através das Equações 4.1 e 4.2. 


$$
\begin{gathered}
\text { Pot }=\gamma * Q * h_{\text {piezõmetro }} \\
G=\sqrt{\frac{\left(\gamma * Q * h_{\text {piezõmetro }}\right.}{\mu * \text { Vol }}}
\end{gathered}
$$$$
\text { (Equação 4.1) }
$$

Em que: Pot (potência hidráulica em kgf.m. $\mathrm{s}^{-1}$ ); $Q$ (vazão em $\mathrm{m}^{3} \cdot \mathrm{s}^{-1}$ ); $h_{\text {piezõmetro }}$ (carga manométrica aplicada no bocal em mca); $G$ (gradiente de velocidade em s${ }^{-1}$ ); $\gamma$ (peso específico em $\left.N . \mathrm{m}^{-3}\right) ; \mu$ (viscosidade dinâmica em $N . \mathrm{s}^{-\mathrm{m}^{-2}}$ ); $\mathrm{Vol}$ (volume do reator $\mathrm{em}^{3}$ ).

O valor de carga manométrica mensurado no piezômetro, juntamente aos dados de vazão e diâmetro do bocal, foram aplicados na lei dos orifícios (que rege a descarga em bocais). A lei dos orifícios é apresentada na Equação 4.3 (AZEVEDO NETTO, 1998). Dessa forma foi possível encontrar o valor do coeficiente de descarga para o bocal utilizado nessa pesquisa.

$$
Q=C D * A_{b} * \sqrt{(2 * g * h}
$$

Em que: $Q$ (vazão em $\mathrm{m}^{3} \cdot \mathrm{s}^{-1}$ ); $C D$ (coeficiente de descarga); $A b$ (área da seção contraída do bocal em $\left.\mathrm{m}^{2}\right) ; g$ (aceleração da gravidade em $\mathrm{m} \cdot \mathrm{s}^{-2}$ ); $h$ (altura manométrica em $\mathrm{m}_{\mathrm{H} 20}$ ).

Para o cálculo de diversos parâmetros do escoamento é importante a determinação do coeficiente de descarga, que varia de acordo com o formato de cada bocal. A determinação do coeficiente de descarga foi possível através da mensuração da vazão e da carga manométrica aplicada ao bocal. O valor de CD será útil na determinação dos parâmetros operacionais, em uma futura extrapolação do sistema para escala plena. A Figura 4.15 apresenta um esquema do sistema anaeróbio, mostrando as cotas piezométricas do reservatório elevado. 


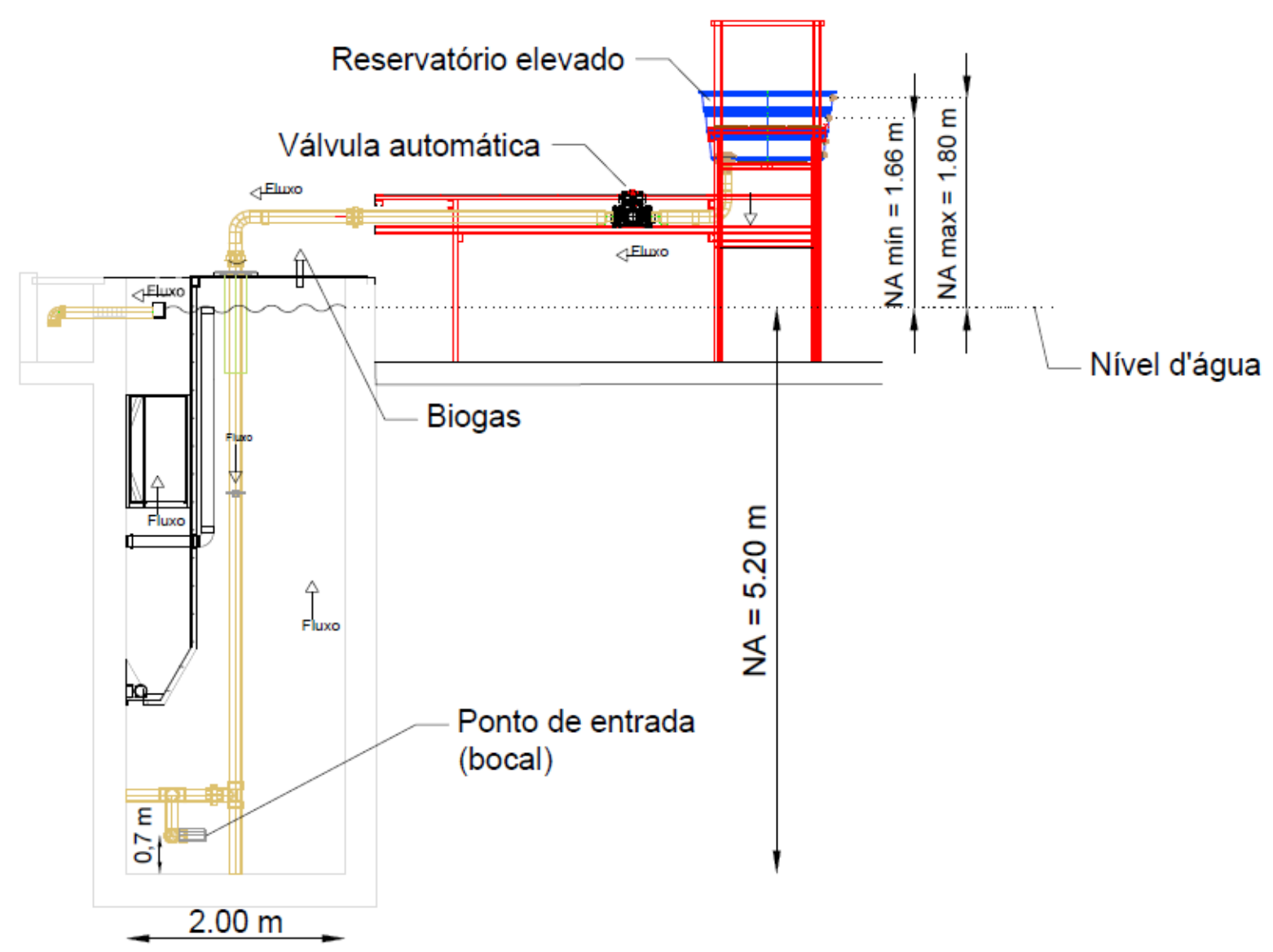

Figura 4.15: Dimensões do reator utilizadas no cálculo da potência de agitação aplicada

Na Equação 4.4 e Equação 4.5 são apresentadas as formulações propostas por Harnby et al (2001) para o alcance máximo e alcance lateral de jatos.

$$
\begin{gathered}
Z=\frac{V j \times D c \times 6}{V Z} \\
A L=\frac{Z}{6}
\end{gathered}
$$

Em que: $Z$ representa o alcance máximo do jato para velocidade adotada (m); $V j$ representa a velocidade do jato na saída do bocal $\left(\mathrm{m} \cdot \mathrm{s}^{-1}\right) ; D c$ representa o diâmetro do bocal na saída do jato $(\mathrm{m}) ; V Z$ representa a velocidade mínima requerida (adotada, $\mathrm{m} . \mathrm{s}^{-1}$ ); e $A L$ representa o alcance lateral total do jato no ponto $Z(\mathrm{~m})$.

Conhecendo-se o valor de coeficiente de descarga e o gradiente de velocidade que se deseja aplicar no tanque, é possível dimensionar um reator em escala plena seguindo o roteiro: 
- Determina-se o volume do tanque a ser agitado e o gradiente de velocidade aplicado para obter a agitação pretendida.

- Com os valores do passo 1 obtêm-se a potência de descarga necessária para promover o gradiente de velocidade, utilizando a Equação 4.2:

$$
G=\sqrt{\frac{P o t}{\mu * V o l}}
$$

- Com o valor de potência, adota-se um valor viável para carga manométrica aplicada e calcula-se a vazão de descarga a partir da Equação 4.1:

$$
\text { Pot }=\gamma * Q * h_{\text {piezõmetro }}
$$

- Adota-se o número de bocais que serão utilizados, e calcula-se a vazão e tempo de descarga para cada bocal.

- Aplica-se a lei dos orifícios (Equação 4.3) para determinação do diâmetro do bocal que atenda aos valores de vazão, carga manométrica e coeficiente de descarga:

$$
Q=C D * A_{b} * \sqrt{(2 * g * h}
$$

- A partir do diâmetro e vazão de descarga do bocal, calcula-se a velocidade do jato empregada no reator.

- Com os valores da velocidade e do diâmetro na saída do bocal é possível calcular o alcance teórico para os jatos (Z e AL), empregando a Equação 4.4 e Equação 4.5.

$$
\begin{gathered}
Z=\frac{V j \times D c \times 6}{V Z} \\
A L=\frac{Z}{6}
\end{gathered}
$$

No item de resultados e discussões (5.5) será dado um exemplo de aplicação deste roteiro para o cálculo de um reator em grande escala. 
O início de operação de reatores biológicos requer grandes cuidados para que a biomassa presente no seu interior não receba sobrecargas orgânicas e hidráulicas, o que pode acarretar no carreamento dessa junto do efluente.

A utilização de biomassa como inóculo visa acelerar o processo de estabilização do reator, pois é inserido no sistema micro-organismos que utilizam o efluente como substrato. Utilizar inóculo de reatores que utilizam efluentes semelhantes contribui para o sucesso nessa fase inicial.

Para o início dos testes no reator piloto de manta de lodo, o reator foi inoculado com 16 $\mathrm{m}^{3}$ de lodo anaeróbio proveniente do reator UASB da estação de tratamento de esgoto do município de São Carlos (220.000 habitantes). Este lodo foi caracterizado em função da série de sólidos, das concentrações de metais e da atividade metanogênica específica.

A partir da constante inibição (Ki) de Mosey (Mosey and Hughes,1975 apud Pierotti, 2007) foi verificado se as concentrações de metais encontradas no lodo poderiam ser inibidoras do processo anaeróbio. A constante de inibição foi calculada a partir da Equação 4.6. Segundo os autores, valores abaixo de 200 não causam danos aos organismos responsáveis pela digestão anaeróbia. Este ensaio foi realizado para o lodo utilizado como inóculo.

$$
K i=\frac{\frac{Z n}{32,7}+\frac{N i}{29,4}+\frac{P b}{103,6}+\frac{C d}{56,2}+\frac{0,67 * C u}{31,8}}{S T}
$$

Em que: $\mathrm{Ki}$ representa parâmetro de Mosey (meq. $\left.\mathrm{kg}^{-1}\right) ; \mathrm{Zn}, \mathrm{Ni}, \mathrm{Pb}, \mathrm{Cd}, \mathrm{Cu}$ representam a concentração dos metais $\left(\mathrm{mg} . \mathrm{l}^{-1}\right) ; S T$ representa sólidos totais do lodo $\left(\mathrm{kg} . \mathrm{l}^{-1}\right)$.

Outro ensaio realizado para caracterizar o lodo foi o teste de atividade metanogênica específica. Este teste foi realizado tanto para o lodo de inóculo, quanto para os pontos inferiores do reator, $\mathrm{P} 0$ e $\mathrm{P} 1$.

O método para o teste de atividade metanogênica do lodo foi descrito por Chernicharo (1997), baseando-se nas pesquisas de De Zeeuw (1984) e Penna (1994). Como materiais, são necessários: lodo que se deseja avaliar, dispositivo de mistura para o lodo, frasco de reação (de 
250 a $500 \mathrm{ml}$ ), frasco com solução alcalina de $\mathrm{NaOH}$ a $5 \%$ para retenção do $\mathrm{CO}_{2}$ e frasco de coleta da solução de $\mathrm{NaOH}$, e substrato a ser degradado (como substrato foi utilizado o próprio esgoto que alimentava as instalações experimentais). Na Figura 4.16 apresenta-se um esquema de montagem simples para determinação de AME.

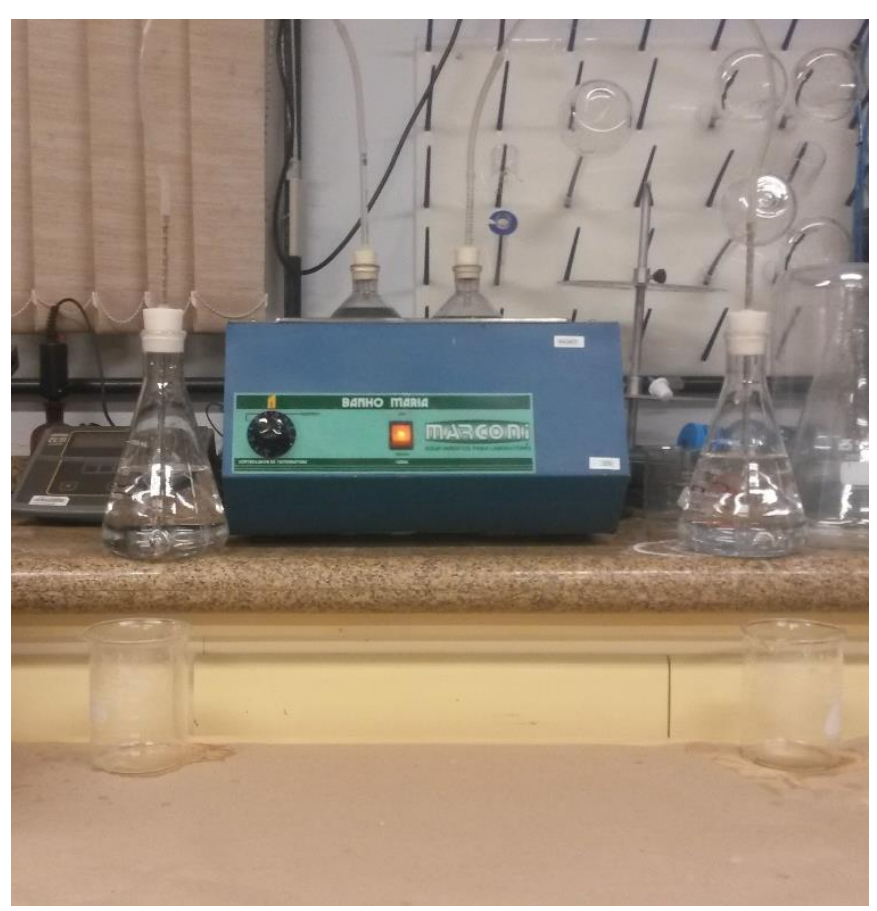

Figura 4.16: Montagem de laboratório para teste AME.

Aquino et al (2007) relataram que em pH neutro, se houver a presença de amônia ela estará quase que em sua totalidade ionizada e dissolvida na parte líquida. Em relação ao sulfeto de hidrogênio, aproximadamente 50\% estará dissolvido na forma iônica. Dessa forma, durante esse ensaio considerou-se apenas o $\mathrm{CO}_{2}$ e o $\mathrm{CH}_{4}$ como os constituintes do biogás gerado.

Para verificar a manutenção da manta de lodo durante o período de operação nessa nova concepção de sistema anaeróbio, foram levantados perfis de sólidos em cinco pontos de amostragem ao longo da altura do reator, pontos esses denominados P0, P1, P2, P3, Topo.

\subsubsection{Análises físico-químicas}

Quando a fermentação ácida predomina sobre a metanogênica ocorre a instabilidade do processo de digestão anaeróbia, que se manifesta nas variações dasvariáveis: $\mathrm{pH}$, ácidos voláteis 
e alcalinidade. Torna-se então imprescindível a análise destas variáveis para avaliar a funcionalidade do reator.

Para o acompanhamento da eficiência de tratamento do esgoto sanitário foram realizadas análises da DQO (amostras bruta e filtrada), série de sólidos, fosfato, sulfeto, NTK e N-amon.

No reator piloto as amostras foram coletadas no reservatório elevado, antes e após o decantador. A coleta em cada ponto era efetuada a cada 2 horas, totalizando amostra composta de 10 horas nos dias de campanha. Essas amostras foram coletadas nas três etapas operacionais.

O tratamento do efluente também foi avaliado ao longo da altura do reator. Foram coletadas amostras simples nos pontos de amostragem de lodo (P0, P1, P2, P3, T), na entrada e na saída do sistema. A determinação dos parâmetros nas parcelas mais espessas do lodo foi viável depois que estas passaram por centrifugação a $3500 \mathrm{rpm}$ por 15 minutos. Desta forma, a fim de validar a comparação dos resultados referentes a todos pontos monitorados, todas as amostras passaram pelo mesmo processo de centrifugação.

Essas amostras eram encaminhadas ao Laboratório de Saneamento, onde realizavam-se as análises físico-químicas (Tabela 4.6), conforme o Standard Methods for the Examination of Water and Watewater (APHA, 2005).

Tabela 4.7: Análises físico-químicas realizadas nas amostras.

\begin{tabular}{|c|c|c|c|}
\hline Variável & Unidade & Nome do Método & Número do Método \\
\hline pH & 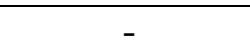 & Potenciométrico - APHA & $4500-\mathrm{H}^{+}(\mathrm{B})$ \\
\hline Ácidos & mg Hac. $1^{-1}$ & Titulométrico - Dilallo e & 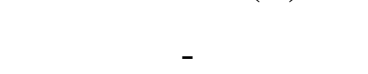 \\
\hline $\begin{array}{l}\text { Voláteis } \\
\text { Alcalinidade }\end{array}$ & $\mathrm{mg} \mathrm{CaCO} 3.1^{-1}$ & $\begin{array}{l}\text { Albertson (1961) } \\
\text { Titulométrico - APHA }\end{array}$ & $2320(\mathrm{~B})$ \\
\hline DQO & $\mathrm{mg} \mathrm{O} 2.1^{-1}$ & Colorimétrico - APHA & 5220 \\
\hline ST & mg. $1^{-1}$ & Gravimétrico - APHA & $2540 \mathrm{~B}$ \\
\hline SF & mg. $1^{-1}$ & Gravimétrico - APHA & $2540 \mathrm{E}$ \\
\hline SV & mg. $1^{-1}$ & Gravimétrico - APHA & $2540 \mathrm{E}$ \\
\hline SST & mg. $1^{-1}$ & Gravimétrico - APHA & $2540 \mathrm{D}$ \\
\hline SSF & $\operatorname{mg} .1^{-1}$ & Gravimétrico - APHA & $2540 \mathrm{E}$ \\
\hline SSV & $\operatorname{mg} .1^{-1}$ & Gravimétrico - APHA & $2540 \mathrm{E}$ \\
\hline $\mathbf{N}-\mathbf{A M O N}$ & $\operatorname{mgN} \mathrm{l}^{-1}$ & Titulométrico - APHA & $4500-\mathrm{NH} 3(\mathrm{C})$ \\
\hline $\mathbf{N}-\mathbf{N T K}$ & $\operatorname{mg~N} .1^{-1}$ & Titulométrico - APHA & $4500-$ Norg B \\
\hline $\mathbf{P}-\mathbf{P O}_{4}^{-}$ & $\mathrm{mg} \mathrm{PO} \mathrm{P}_{4} \mathrm{l}^{-1}$ & Colorimétrico - APHA & $4500-$ \\
\hline Metais & - & Espectrométrico - APHA & 3030 \\
\hline
\end{tabular}


Como etapa de pós-tratamento do efluente do reator anaeróbio foi utilizada a filtração rápida empregando areia como meio filtrante. $\mathrm{O}$ efluente foi aplicado no filtro com fluxo de escoamento descendente e em meio não-pressurizado.

O filtro foi construído utilizando tubo de PVC com diâmetro interno de $100 \mathrm{~mm}$ (área superficial de $0,00785 \mathrm{~m}^{2}$ ), e fixado na parede do sistema anaeróbio. Na Figura 4.17 é apresentada fotografia e desenho esquemático dessa unidade de tratamento.

Para alimentação do filtro, foi utilizada uma bomba de diafragma que recalcava parte da vazão do efluente na saída do sistema de decantação. A taxa de aplicação superficial média no filtro foi estabelecida em $100 \mathrm{~m}^{3} \cdot \mathrm{m}^{-2} \cdot \mathrm{dia}^{-1}$.

O leito de filtração, com 1,5 m de espessura, foi composto por areia com grãos de dimensões entre 0,6 e 2,36 mm. O ensaio de distribuição granulométrica da areia utilizada como meio filtrante foi disponibilizada pelo fornecedor da areia (Mineração Jundu Ltda). Esse ensaio foi realizado de acordo com as diretrizes preconizadas na ABNT/NBR 7181/1984 que trata da análise granulométrica de solos. Na Tabela 4.7 estão expostos os resultados do ensaio. A Figura 4.18 ilustra a curva de distribuição granulométrica obtida a partir da Tabela 4.7.

Tabela 4.8: Ensaio granulométrico da areia componente do meio filtrante.

\begin{tabular}{ccc}
\hline Número de malhas por polegada & Abertura da malha $(\mathbf{m m})$ & \% massa retida \\
\hline 8 & 2,36 & 0 \\
10 & 2,00 & 1,1 \\
12 & 1,70 & 12,3 \\
14 & 1,40 & 37 \\
16 & 1,18 & 39,3 \\
18 & 1,00 & 8,2 \\
20 & 0,85 & 1,9 \\
30 & 0,60 & 0,2 \\
40 & 0,425 & 0 \\
\hline
\end{tabular}



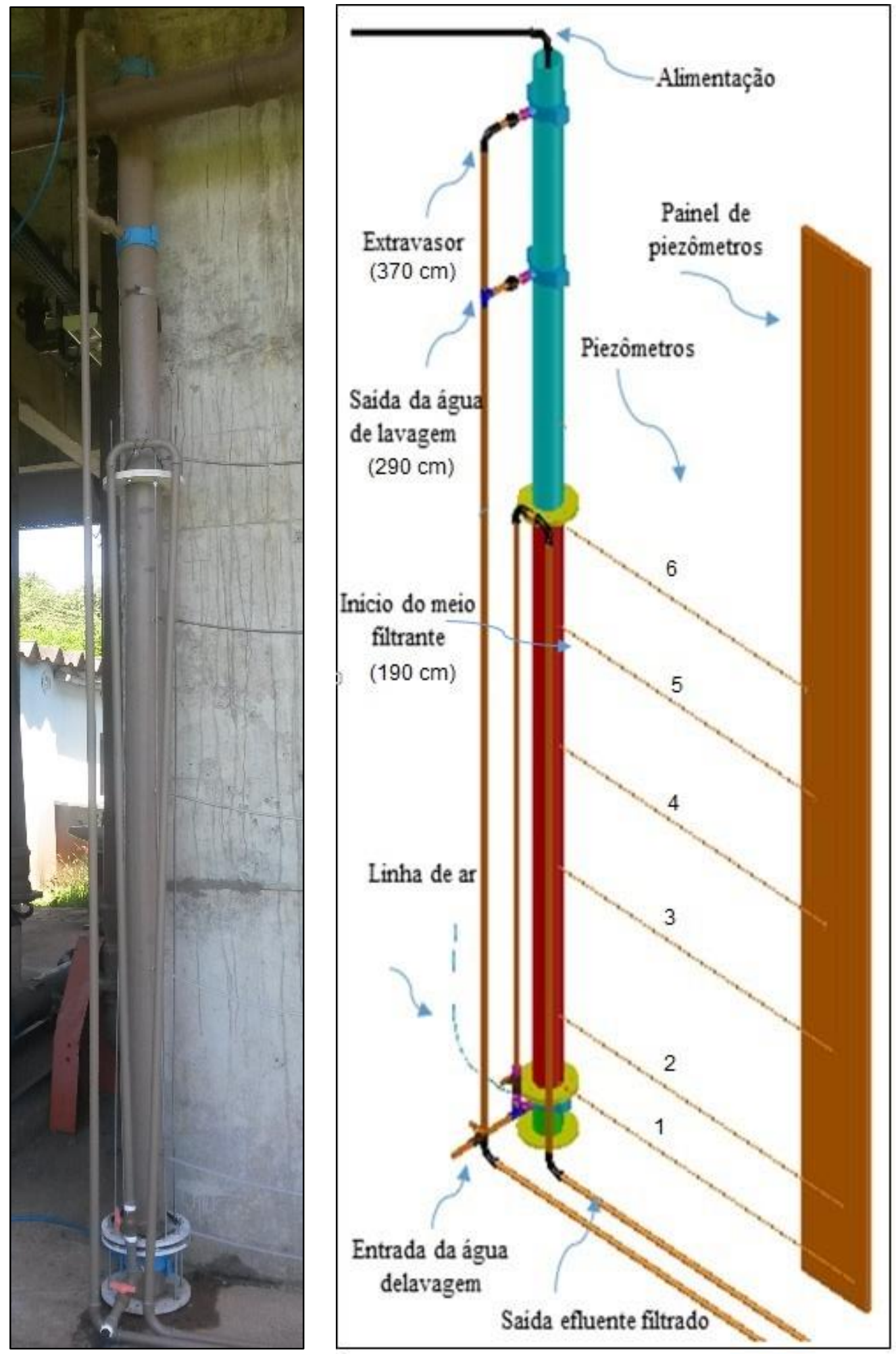

Figura 4.17: Fotografia e desenho esquemático do filtro de areia descendente. 


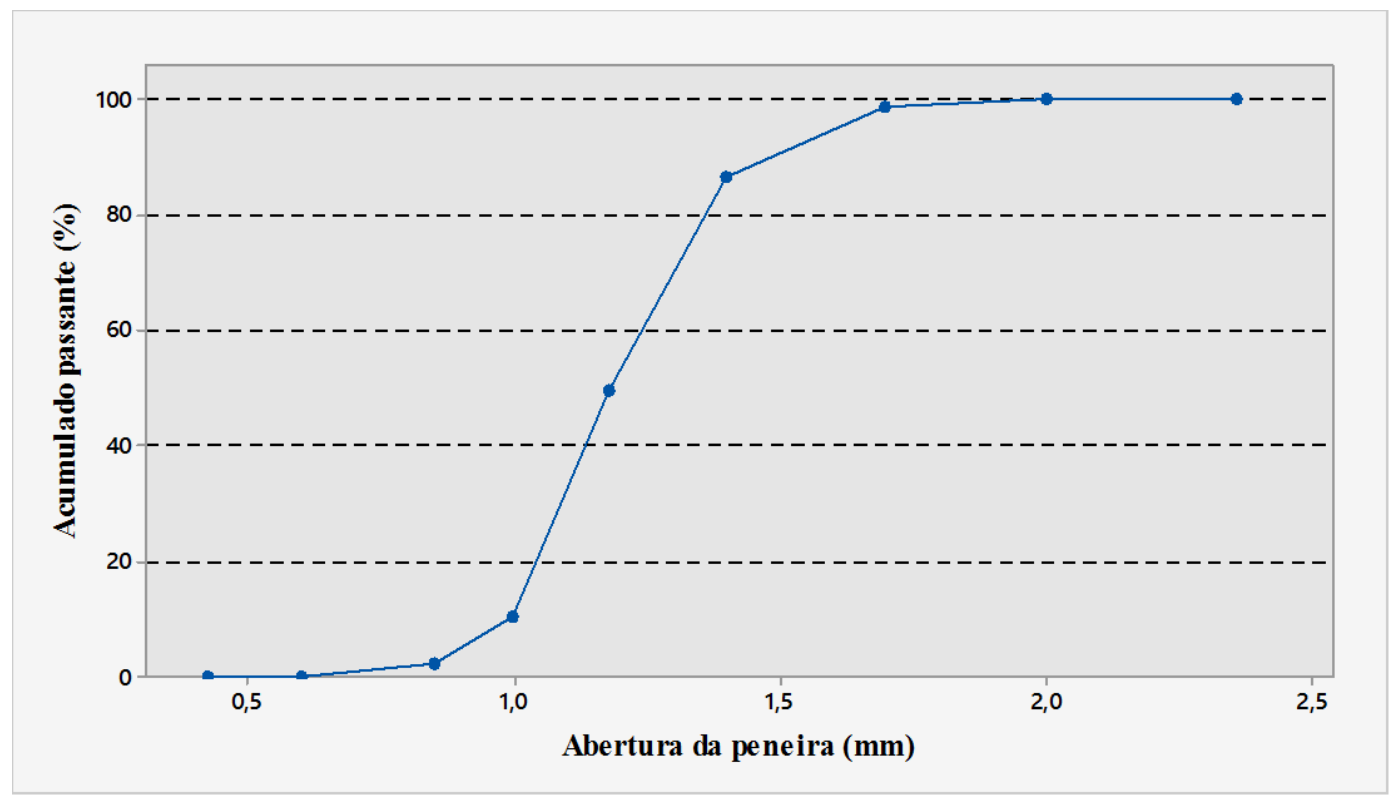

Figura 4.18: Curva de distribuição granulométrica do meio filtrante.

A partir da curva de distribuição granulométrica foi determinado o diâmetro efetivo da areia $\left(\mathrm{D}_{10}=1,00\right)$ e o coeficiente de não-uniformidade de $1,24\left(\mathrm{D}_{60} / \mathrm{D}_{10}=1,24 ;\right)$. Essas características granulométricas permitem extensão na duração da carreira de filtração segundo os dados da bibliografia apresentados no item 3.5.

Em relação à camada suporte foram utilizadas quatro camadas de granulometria distinta, com $25 \mathrm{~cm}$ de espessura, cujas características estão apresentadas na Tabela 4.8. Na Figura 4.19 são exibidas fotografias dos materiais utilizados no leito de filtração e nas camadas suporte.

Tabela 4.9: Características da camada suporte do filtro.

\begin{tabular}{lccc}
\hline & Espessura (m) & Volume (l) & Granulometria (mm) \\
\hline Camada suporte 1 & 0,1 & 0,079 & $19-12,5$ \\
Camada suporte 2 & 0,05 & 0,039 & $12,5-6,3$ \\
Camada suporte 3 & 0,05 & 0,039 & $6,3-3,35$ \\
Camada suporte 4 & 0,05 & 0,039 & $3,35-1,7$ \\
Camada filtrante & 1,5 & 11,775 & $0,6-2,36$ \\
\hline
\end{tabular}



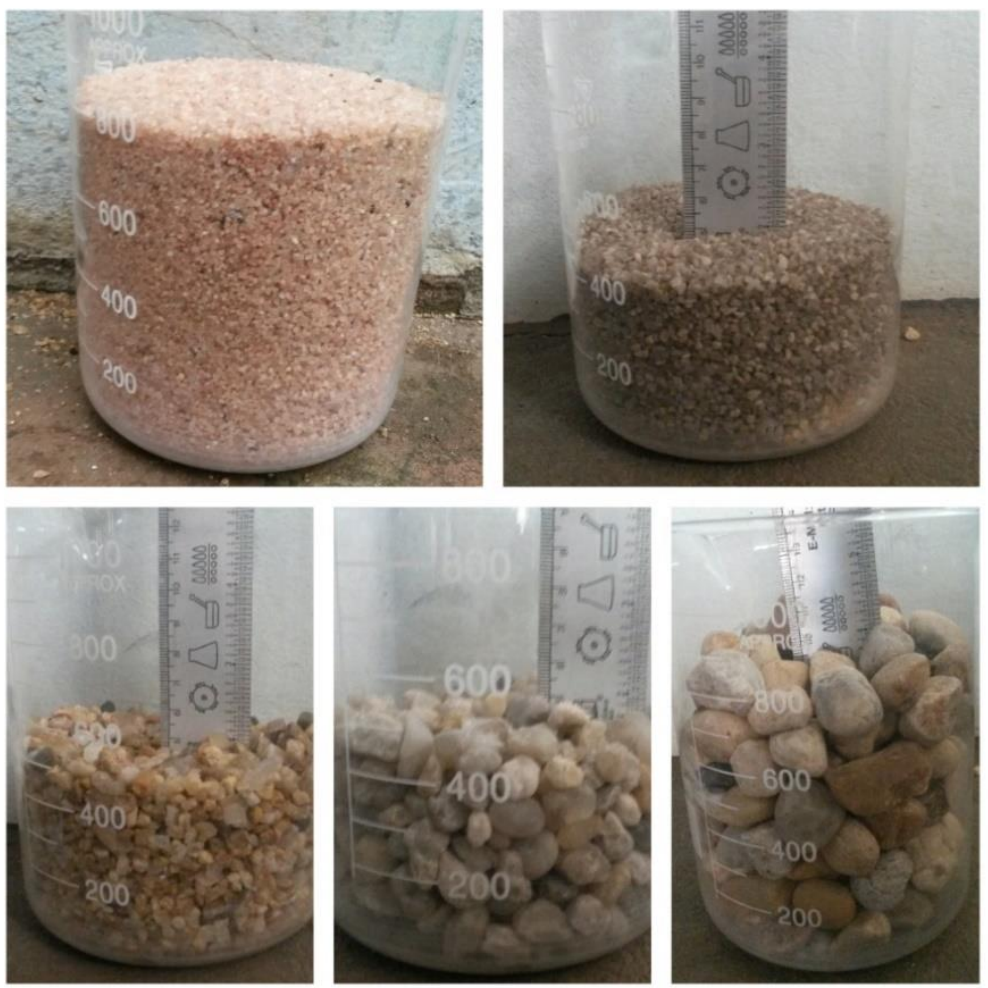

Figura 4.19: Características granulométricas do leito de filtração e da camada suporte.

O fim da carreira de filtração foi determinado quando alcançou-se a perda de carga máxima de 1,30. Para aferição da perda de carga ao longo do leito de areia foram instalados 6 piezômetros, cujos posicionamentos estão descritos na Tabela 4.9.

Tabela 4.10: Posicionamento dos piezômetros, em relação ao fundo do filtro, para aferição da perda de carga:

\begin{tabular}{cccc}
\hline & Diâmetro $(\mathbf{m m})$ & Altura da aferição $(\mathbf{c m})$ & Local \\
\hline Piezômetro 1 & 6 & 15 & Fundo mat. Suporte \\
Piezômetro 2 & 6 & 40 & Fundo leito filtrante \\
Piezômetro 3 & 6 & 90 & Meio Leito filtrante \\
Piezômetro 4 & 6 & 140 & Meio Leito filtrante \\
Piezômetro 5 & 6 & 190 & Topo Leito filtrante \\
Piezômetro 6 & 6 & 240 & Saída efluente \\
\hline
\end{tabular}

Para a lavagem do filtro, foi mantido um fundo falso de $15 \mathrm{~cm}$ de altura, por onde ingressava o ar e a água. O procedimento de lavagem foi baseado na metodologia proposta por 
Di Bernardo (1988). Essa metodologia foi desenvolvida para filtros rápidos com areia de diâmetro efetivo entre 0,95 e 1,35 mm. Como primeiro passo, extingue-se a alimentação do sitema de filtração, e introduz-se água e ar em contracorrente durante 5 minutos. A vazão de água aplicada foi da ordem de 4 1/s.m² e a vazão de ar baixa para obter expansão do leito de filtração de até $5 \%$. Após os cinco minutos iniciais, interrompe-se a linha de água e aplica-se somente o ar, em taxa maior, por 3 minutos. Depois se interrompe a aplicação de ar e aplica-se somente água até atingir a expansão desejada.

A saída da água de lavagem foi instalada a $100 \mathrm{~cm}$ do topo da camada filtrante, para possibilitar a expansão de $50 \%$ do meio filtrante durante a lavagem do filtro sem que houvesse risco de perda de grãos. Também foi disposto um extravasor a $180 \mathrm{~cm}$ do topo do leito.

Para avaliação da funcionalidade do sistema de filtração foram tomadas amostras, na entrada e saída do sistema de filtração, para mensuração das seguintes variáveiss: DQO, SST, cor, turbidez. Também foi medida a evolução da perda de carga ao longo do meio filtrante. 


\section{RESULTADOS E DISCUSSÕES}

\subsection{Considerações gerais}

A apresentação dos resultados está dividida de acordo com as fases experimentais realizadas. Sendo assim, os resultados são apresentados para os reatores de bancada da fase 1, o reator da fase 2 e o reator da fase 3 separadamente.

Nas duas primeiras fases é dada ênfase ao comportamento do lodo anaeróbio e a viabilidade do bocal em vista da sua eficiência para alcançar a agitação. Na terceira fase, os resultados buscaram explorar os ajustes iniciais e operacionais, de acordo com o exposto no item 5.4.

\subsection{Fase 1: Agitação em reatores de bancada}

A influência do gradiente de agitação no que tange à manutenção de manta de lodo foi estudada em reatores de bancada. No ensaio dos reatores de bancada a agitação com gradiente de velocidade $(G)$ menores que $20 \mathrm{~s}^{-1}$ se mostrou suficiente para a manta de lodo estar bem configurada e sem arraste significativo de sólidos no efluente em operação contínua.

Foi observado, também, durante o estudo que, quando a agitação dos reatores era interrompida, o gradiente de velocidade precisava ser elevado logo a seguir, para um valor em torno de $80 \mathrm{~s}^{-1}$, a fim de garantir a ressuspensão do lodo sedimentado.

Com relação à eficiência dos reatores, sob as condições apresentadas no item 4.2, os resultados, indicam que o reator sem agitação obteve maior eficiência média (Tabela 5.1) na remoção de DQO bruta. Porém esse cenário é incompatível com conhecimentos práticos observados em reatores de escala plena.

É possível observar médias elevadas na remoção de DQO principalmente para o nono dia de operação (as amostras desse dia tiveram remoção elevada devido à alta DQO na entrada dos reatores - Figura 5.1). Em geral, os reatores alcançaram eficiências semelhantes ao se 
comparar a operação com e sem agitação. Para os reatores com agitação, observou-se uma sutil melhora sob tempo de detenção de 4 horas.

Tabela 5.1: Desempenho dos reatores de bancada tratando esgoto sanitário.

\section{Eficiência de remoção de DQO bruta (\%)}

\begin{tabular}{|c|c|c|c|}
\hline $\begin{array}{l}\text { Dias de operação } \\
\quad\left(T=20^{\circ} \mathrm{C}\right)\end{array}$ & $\begin{array}{c}\text { Reator } 1 \\
\text { TDH }=4 \mathrm{~h} \\
\mathrm{G}=20 \mathrm{~s}^{-1}\end{array}$ & $\begin{array}{c}\text { Reator } 2 \\
\text { TDH }=8 \mathrm{~h} \\
\mathbf{G}=20 \mathrm{~s}^{-1}\end{array}$ & $\begin{array}{c}\text { Reator } 3 \\
\text { TDH }=8 \text { h } \\
\text { Sem agitação }\end{array}$ \\
\hline 9 & 91,3 & 83,2 & 90,1 \\
\hline 16 & 54,2 & 65,7 & 73 \\
\hline 23 & 41,5 & 47,8 & 49,8 \\
\hline 30 & 82,3 & 64,3 & 87,1 \\
\hline 37 & 69,9 & 56 & 65,6 \\
\hline Média & 67,84 & 63,4 & 73,12 \\
\hline
\end{tabular}

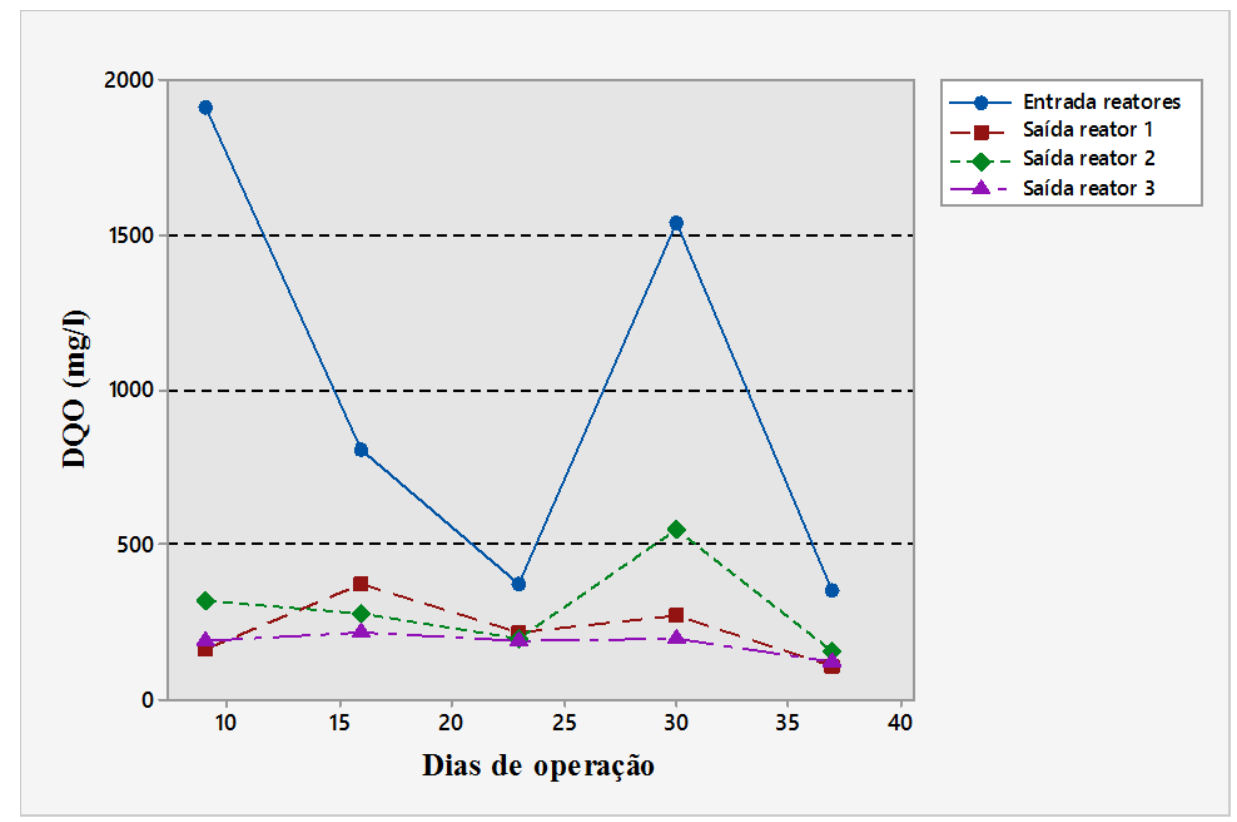

Figura 5.1: Valores de DQO na entrada e saída dos reatores de bancada.

Ao se comparar as médias de eficiência de cada período em relação à presença ou não de agitação é possível observar queda na eficiência de remoção para os reatores com agitação e maior período. Tal comportamento pode estar associado a presença de sólidos suspensos no efluente do tratamento. No reator sem agitação, devido a sedimentação, o lodo permanecia distante do ponto de coleta, como pôde ser observado na Figura 4.4. Essa constatação foi importante para determinar a necessidade da manutenção da manta de lodo, bem como prever 
uma unidade para remoção de sólidos suspensos, mesmo diante dos resultados satisfatórios para os três reatores.

\subsection{Fase 2: Estudo de reator piloto agitado por jatos}

\subsubsection{Introdução}

Como já mencionado no item 4.3, foram feitos testes preliminares, em reator de acrílico com volume de $2,69 \mathrm{~m}^{3}$, para verificar o sistema com água e com esgoto e lodo de reator anaeróbio. Além disso foi possível verificar o impacto da utilização da alimentação através de descargas intermitentes no padrão de escoamento do reator.

\subsubsection{Determinação do tempo de mistura}

Neste ensaio, utilizando a rodamina $\beta$ como traçador, além de estimar o tempo de mistura foi possível visualizar algumas particularidades dos jatos de alimentação. Observou-se como a mistura do fluido de entrada com o fluido em repouso ocorreu em todas direções, influenciados pela energia do jato e também pelo choque e revolvimento desses jatos com as paredes. Na Figura 5.2 as imagens temporizadas ilustram o ingresso dos jatos no reator, nas quais, pode-se notar características descritas na revisão bibliográfica, como a turbulência na região imediata a saída do bocal, a propagação axial e radial do jato, e a formação de vórtices.

O tempo total do pulso de alimentação foi de 1 minuto, e a velocidade média em cada jato foi de 2,0 m.s $\mathrm{s}^{-1}$. Entretanto, após 20 segundos da entrada do jato era possível visualizar a influência do traçador na totalidade do reator, o que certamente influenciou na obtenção de elevada mistura, atestada nos ensaios hidrodinâmicos. 
$\underline{\text { Tempo de aplicação do traçador: } 4 \text { segundos }}$
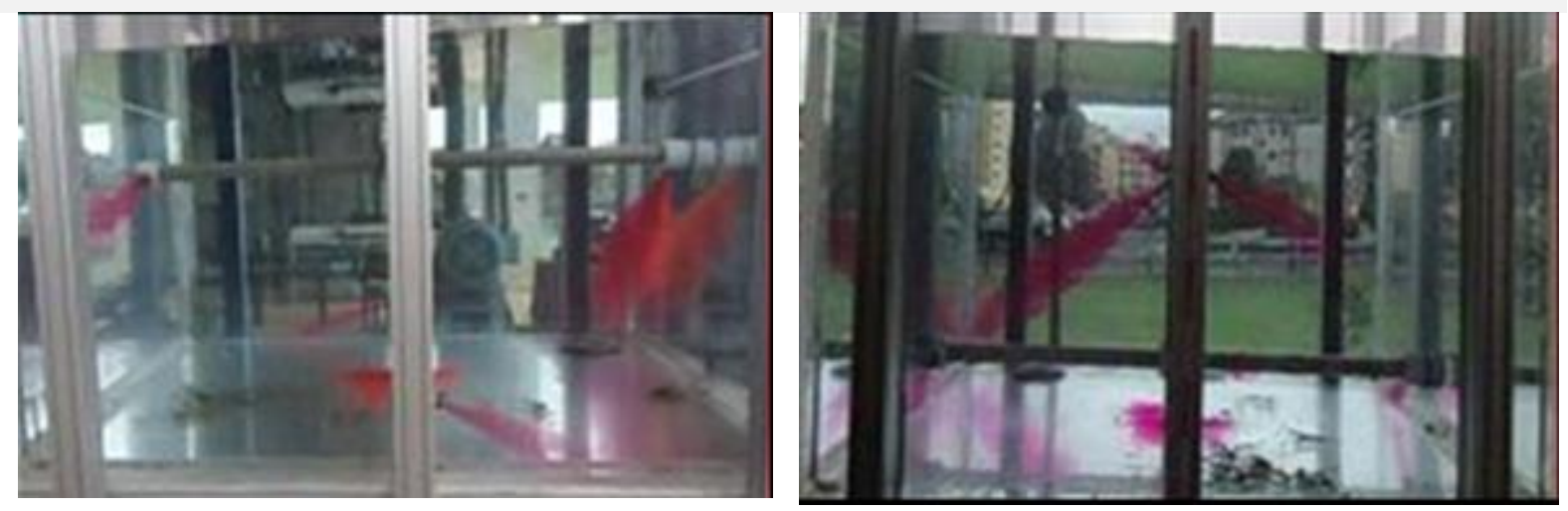

Tempo de aplicação do traçador: 10 segundos
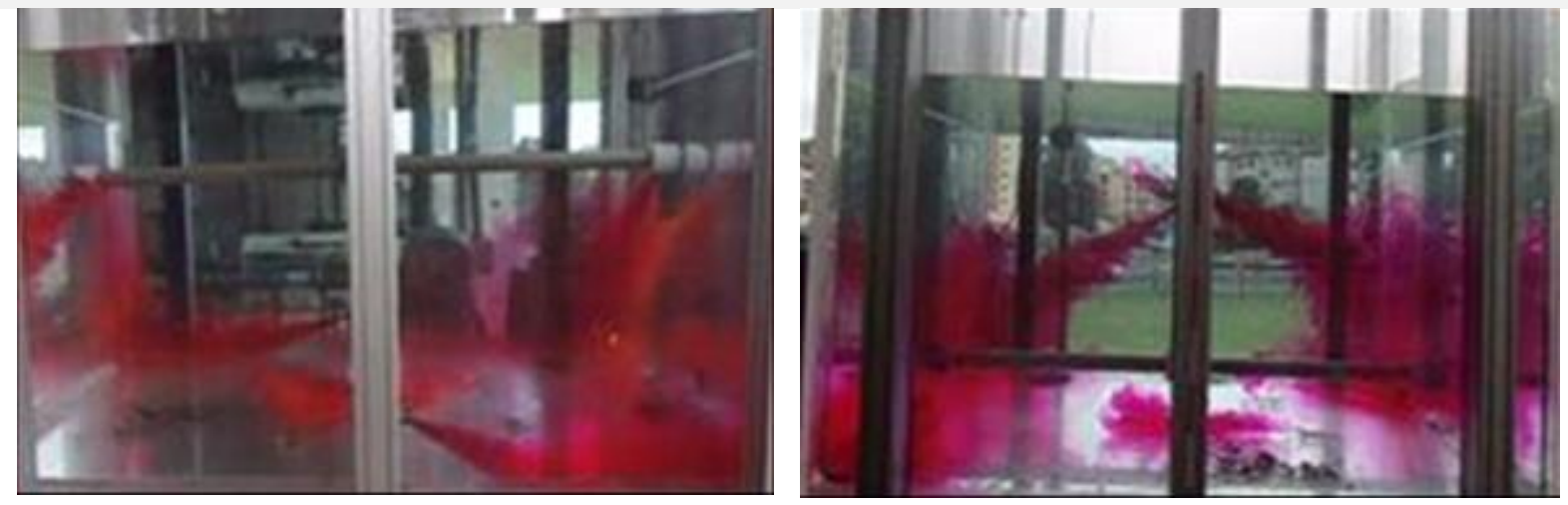

Tempo de aplicação do traçador: 20 segundos
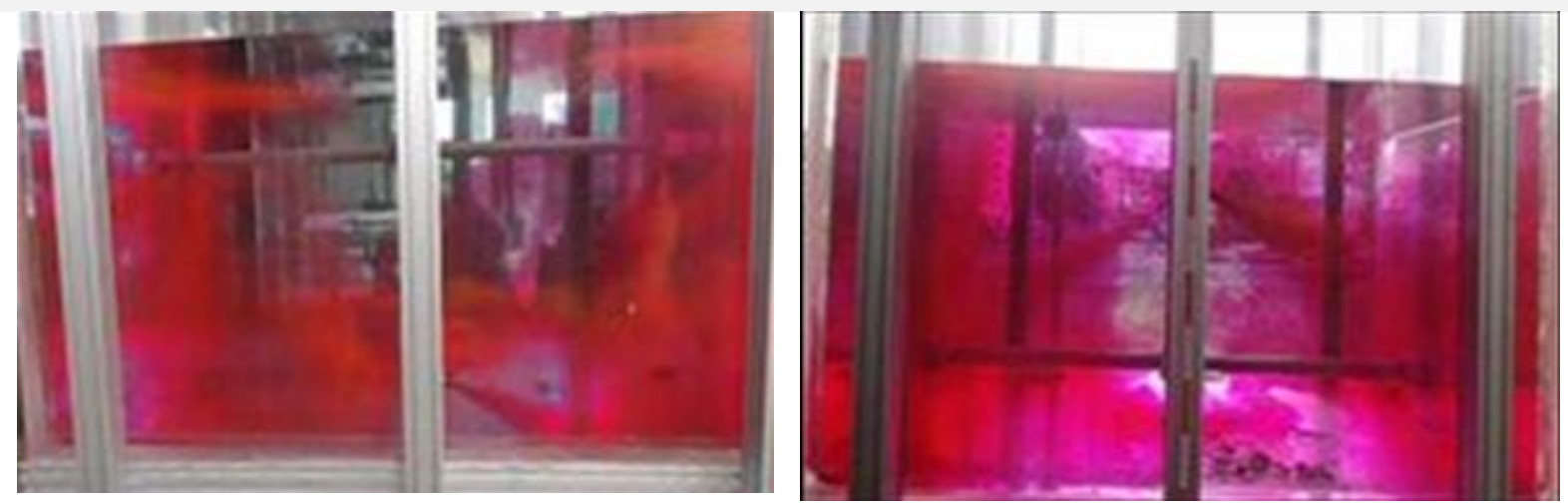

Figura 5.2: Aplicação dos jatos turbulentos na alimentação do reator. 


\subsubsection{Ensaios hidrodinâmicos}

Para a realização dos ensaios hidrodinâmicos o reator de acrílico foi preenchido com água, e solução salina de cloreto de sódio foi utilizada como traçador. Não foi possível a realização de ensaios com o reator preenchido com lodo anaeróbio pois a capacidade de retenção do lodo deste reator mostrou-se insuficiente. Cada descarga do reservatório elevado tinha duração de 1 minuto, resultando em velocidade média do jato na saída de cada bocal de $1,7 \mathrm{~m} \cdot \mathrm{s}^{-1}$.

\subsubsection{Ensaio com solução salina e TDH teórico $=6,25 \mathrm{~h}$}

Na Figura 5.3 é apresentada a curva de distribuição do tempo de residência (DTR) do traçador no interior do reator. O tempo de detenção hidráulica real do reator obtido foi igual a 4,8 horas. O desvio encontrado entre o TDH teórico (6,25 horas) e o TDH amostral (4,8 horas) de $23 \%$, reflete as zonas de curto-circuito e caminhos preferenciais do reator, para essa configuração e vazão do reator.

A curva obtida na Figura 5.3 assemelha-se com a curva citada por Levenspiel (2000) ilustrada na Figura 5.4 - para escoamento em mistura completa para o cenário dos testes. Essa observação deve ser destacada já que em um sistema com mistura completa, o carreamento de sólidos junto ao efluente é elevado, indicando a relevância do uso de sistema de decantação de alta taxa na saída do efluente do reator.

Além da curva de concentração por tempo (DTR), procedeu-se a análise do reator através dos modelos uniparamétricos de desvios de escoamento, cujos resultados são apresentados na Tabela 5.2.

Em relação ao modelo de baixa dispersão axial, resultados acima de 0,01 mostram tendência do reator ao escoamento em mistura completa e resultados tendendo ao zero representam escoamentos plug-flow. Já em relação ao modelo de número de tanques completamente agitados em série (N-CSTR) quanto mais próximo o valor à unidade, o escoamento está mais próximo da mistura completa. 
Tabela 5.2: Resultado dos modelos uniparamétricos para o escoamento do reator operando com $\mathrm{TDH}=6,25 \mathrm{~h}$.

\begin{tabular}{cc}
\hline Dispersão Axial & Tanques em série (N-CSTR) \\
\hline 0,221 & 2,3 \\
\hline
\end{tabular}

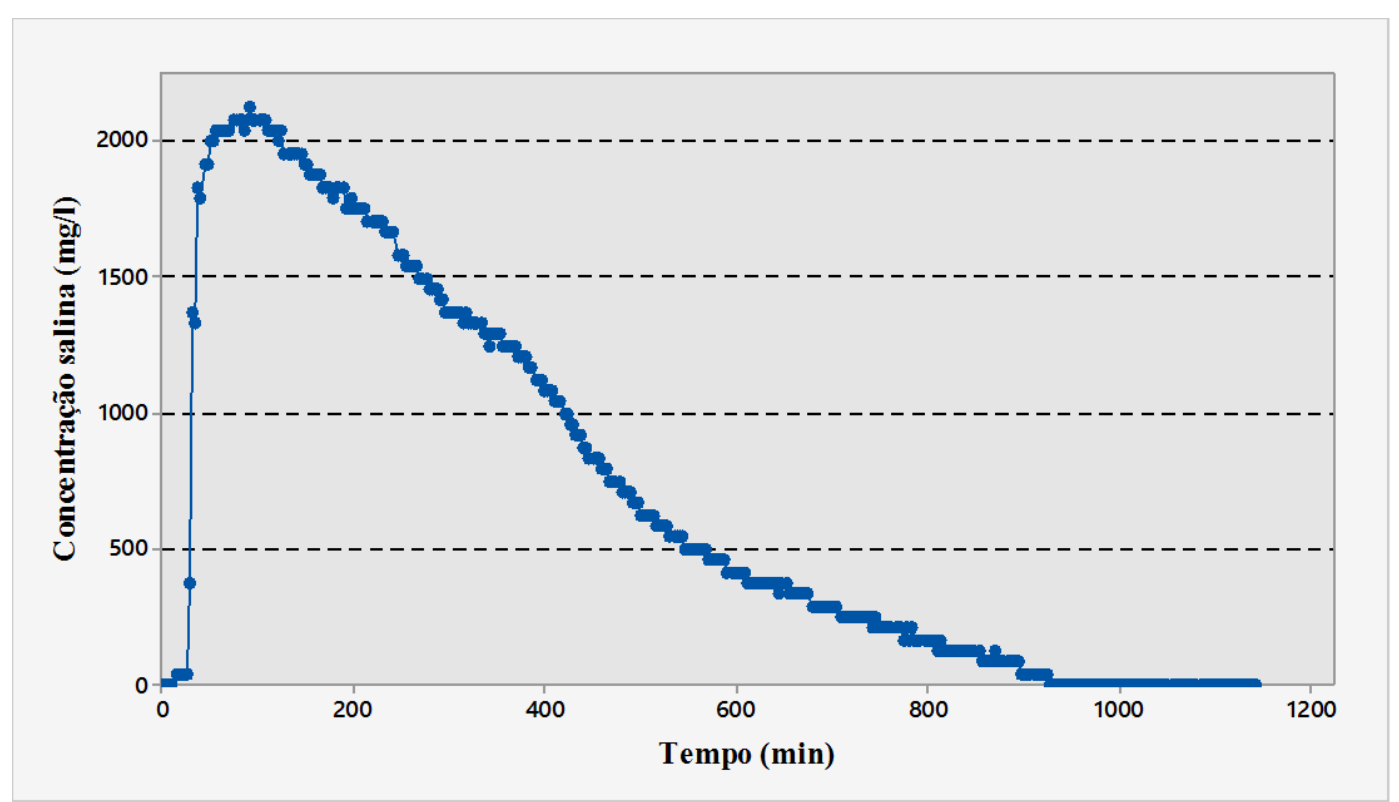

Figura 5.3: Curva de distribuição de tempo de residência para o TDH de 6,25 h.

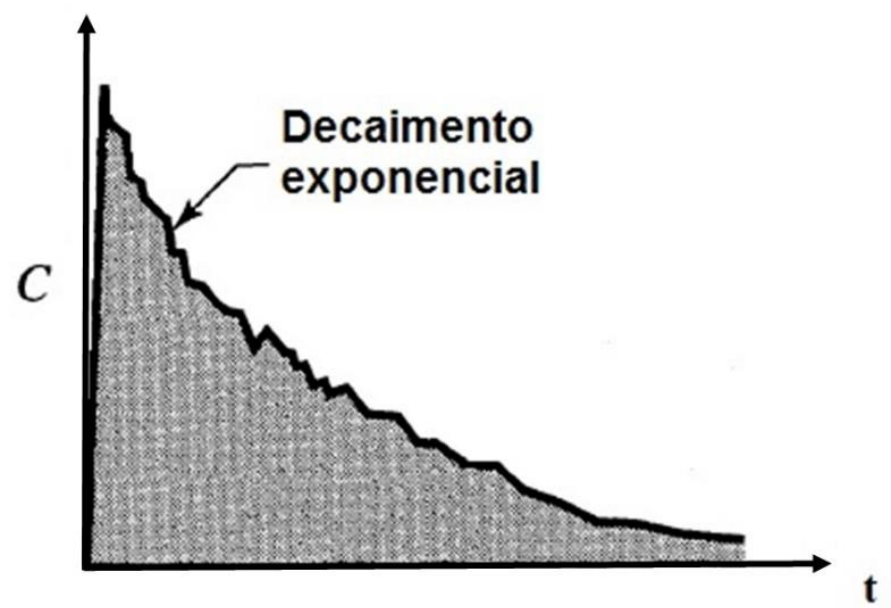

Figura 5.4: Representação da curva DTR para escoamento com tendência à mistura completa (adaptado de Levenspiel, 2000) 


\subsubsection{Ensaio com solução salina e $T D H=4,2 \mathrm{~h}$}

Procedeu-se a realização de outro ensaio hidrodinâmico buscando observar a diferença no comportamento do reator, quando aplicada vazão superior e, portanto, menor TDH. A realização desse experimento obedeceu aos mesmos critérios do ensaio com TDH de 6,25 horas.

A curva DTR para este ensaio é apresentada na Figura 5.5. Novamente, o formato da curva se assemelha com a apresentada por Levenspiel (2000) para reatores com comportamento de regime de mistura completa.

Em relação ao tempo de detenção hidráulica, o TDH amostral foi de 3,14 horas, enquanto o TDH teórico era de 4,2 horas. Isso representa uma diferença de $25 \%$, valor bem próximo ao encontrado no ensaio anterior.

O resultado obtido do modelo de dispersão axial, também se assemelha ao ensaio anterior como pode ser notado na Tabela 5.3. Dessa forma, os resultados apresentados pelas curvas DTR mostram que o reator se aproxima do regime de mistura completa tanto para tempo de detenção teórico em torno de 4 horas quanto para 6 horas. Esse resultado já era esperado pois o volume de descarga é praticamente o mesmo nos dois casos, já que o tempo de enchimento do reservatório elevado é o parâmetro afetado ao variar a vazão afluente.

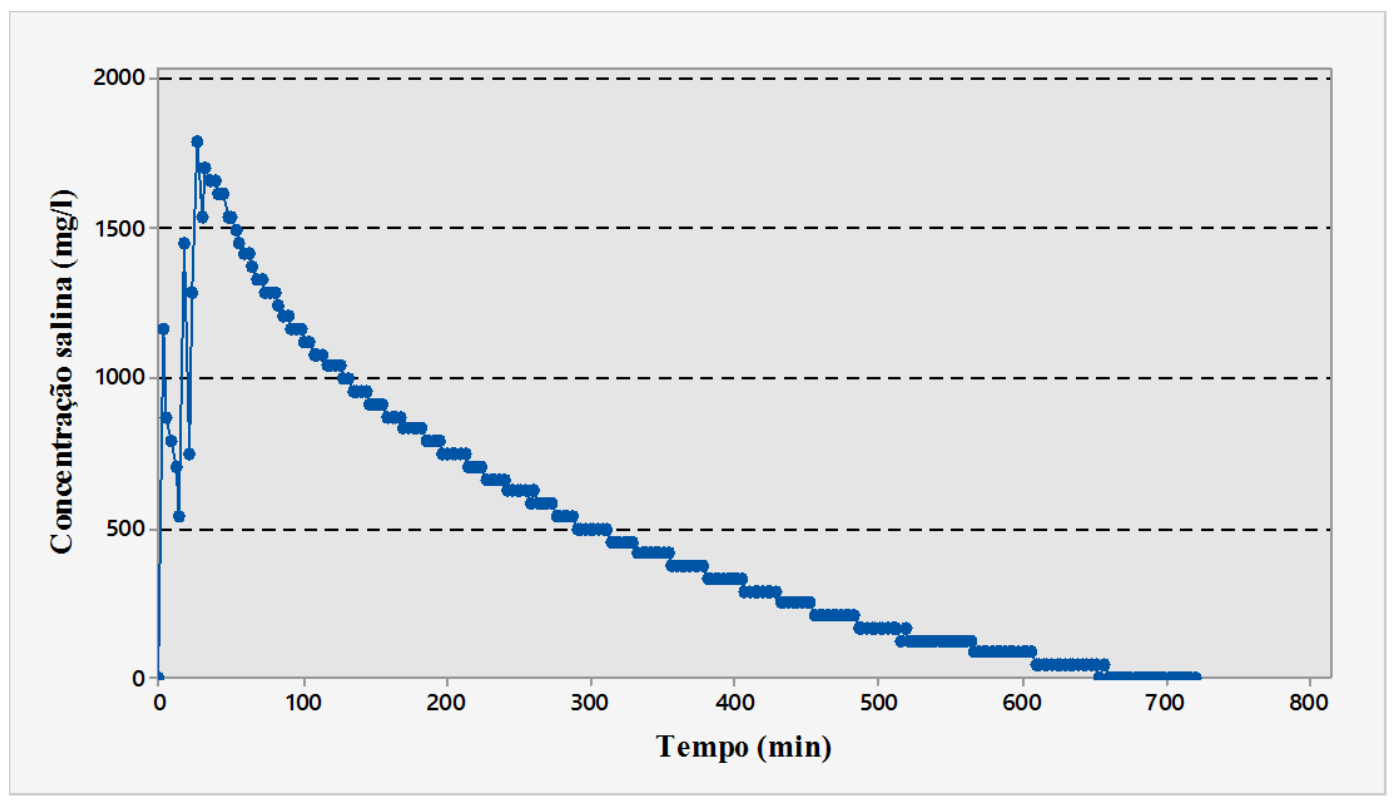

Figura 5.5: Curva de distribuição do tempo de residência para a solução salina aplicada ao reator e $\mathrm{TDH}=4,2 \mathrm{~h}$. 
Na Tabela 5.3 estão comparados os resultados dos dois testes hidrodinâmicos. Observase grande similaridade dos resultados obtidos nessa pesquisa com os dados já existentes na bibliografia (PASSIG, 2005), representando que o escoamento do reator proposto está em sintonia com o escoamento existente na atual configuração UASB. Ressalta-se que o reator de Passig (2005) é a mesma unidade usada nesta pesquisa, porém com configuração típica de reator UASB convencional.

Tabela 5.3: Comparação do resultado dos modelos uniparamétricos para diversos escoamentos.

\begin{tabular}{cccc}
\hline & \multicolumn{2}{c}{ Reator piloto } & Reator UASB USP (Passig, 2005) \\
& TDH = 6,25 h & $\mathbf{T D H}=\mathbf{4 , 2} \mathbf{~ h}$ & TDH = 8,8 h \\
\hline Baixa Dispersão & 0,221 & 0,295 & 0,22 \\
N-CSTR & 2,3 & 1,7 & 2,23 \\
\hline
\end{tabular}

Através da análise do comportamento dos traçadores no reator foi possível notar que o grau de mistura proporcionado pelos bocais foi elevado, mesmo utilizando uma velocidade baixa dos jatos. Essa agitação elevada deve ser evitada em projetos em que se desejem manter manta de lodo. Os resultados desses ensaios foram importantes para a determinação da forma de alimentação do sistema da fase 3 os quais foram: menor tempo de descarga e bocal posicionado horizontalmente.

\subsubsection{Operação no reator}

Após os testes hidrodinâmicos com água no reator de acrílico este foi inoculado com lodo e esperava-se que fosse possível manter operação contínua por alguns meses. Dessa forma seria possível avaliar os pontos positivos e negativos dessa configuração de reator, e essas conclusões contribuiriam para aperfeiçoamento, se necessário, no momento de reformar o reator piloto de $20,8 \mathrm{~m}^{3}$.

Porém, não foi possível manter uma operação contínua, pois o lodo era carreado constantemente junto ao efluente. Para exemplificar como foi falho o desempenho do reator no tratamento de esgoto sanitário, a melhor remoção de DQO obtida em meses de operação foi de $35 \%$. 
Muitas das dificuldades operacionais apresentadas nesta fase da pesquisa resultaram em aprendizado com relação ao sistema de alimentação e caixa de armazenamento do esgoto, a montante dos bocais. Dentre tantos, a sequência de falhas e problemas mostrou a importância de dois pontos essenciais: i) o primeiro é a necessidade de decantador após a unidade anaeróbia; ii) o segundo é a obrigatoriedade de operação ininterrupta do sistema, para evitar maior produção de gases na forma de picos e consequente arraste de lodo.

\subsection{Fase 3: Sistema piloto de manta de lodo}

\subsubsection{Caracterização do lodo utilizado como inóculo}

O lodo utilizado como inóculo, conforme apresentado no item 4.4.4.2, apresentava-se com as seguintes características principais: sólidos suspensos totais $\left(22.389 \mathrm{mg} . \mathrm{l}^{-1}\right)$, sólidos suspensos voláteis (13.940 mg. $\left.\mathrm{l}^{-1}\right)$, atividade metanogênica específica com valor de $(0,034 \mathrm{~kg}$ $\left.\mathrm{DQO}_{\mathrm{rem}} \cdot \mathrm{kg} \mathrm{ssv}^{-1} \cdot \mathrm{dia}^{-1}\right)$. As concentrações de metais desse lodo estão detalhadas na Tabela 5.4 .

Tabela 5.4: Concentração de metais no lodo usado como inóculo.

\begin{tabular}{|c|c|c|c|c|c|c|c|}
\hline $\begin{array}{c}\text { Zn } \\
\left(\mathrm{mg.l}^{-1}\right)\end{array}$ & $\begin{array}{c}\text { Pb } \\
\left(\mathrm{mg.l}^{\left.\mathbf{l}^{-1}\right)}\right.\end{array}$ & $\begin{array}{c}\text { Cd } \\
\left(\mathbf{m g . l}^{-1}\right)\end{array}$ & $\begin{array}{c}\mathrm{Ni} \\
\left(\mathrm{mg.l}^{-1}\right)\end{array}$ & $\begin{array}{c}\text { Fe } \\
\left(\mathrm{mg.l}^{\left.\mathbf{l}^{-1}\right)}\right.\end{array}$ & $\begin{array}{c}\text { Mn } \\
\left(\mathrm{mg.l}^{-1}\right)\end{array}$ & $\begin{array}{c}\mathrm{Cu} \\
\left(\mathrm{mg.l}^{-1}\right)\end{array}$ & $\begin{array}{c}\mathrm{Cr} \\
\left(\mathrm{mg.l}^{-1}\right)\end{array}$ \\
\hline 22,16 & 0,54 & 0,035 & 5,66 & 527 & 2,43 & 4,38 & 8,97 \\
\hline
\end{tabular}

Quanto à inibição da comunidade anaeróbia por metais verificou-se, por meio da Equação 4.6, que a constante de inibição de Mosey para o lodo em análise resultou em 45,55. A constante está abaixo do limite (200) para que os microrganismos anaeróbios sofram interferência dos metais presentes.

Durante o período de ajustes iniciais, com duração de 150 dias, houve arraste do lodo, sendo necessário acrescentar ao reator mais $40 \mathrm{~m}^{3}$ de lodo, visando aumentar a carga biológica ativa do sistema $\left(10 \mathrm{~m}^{3}\right.$ por vez). As reinoculações ocorreram nos $45^{\circ}, 85^{\circ}, 113^{\circ}$ e $150^{\circ}$ dias após a primeira inoculação. 
A Tabela 5.5 apresenta a concentração de sólidos dos inóculos utilizados posteriormente. Observa-se também que os inóculos utilizados apresentaram concentrações de sólidos e parcelas biodegradáveis (SSV/SST) semelhantes.

Tabela 5.5: Concentração de sólidos das amostras de lodo anaeróbio adicionado ao reator na etapa de ajustes iniciais.

\begin{tabular}{ccccc}
\hline Dias de operação & Volume acrescentado $\left(\mathbf{m}^{\mathbf{3}}\right)$ & $\begin{array}{c}\text { SST } \\
\left(\mathbf{m g . \mathbf { l } ^ { - 1 }}\right)\end{array}$ & $\begin{array}{c}\text { SSV } \\
\left(\mathbf{m g . l ^ { - 1 }}\right)\end{array}$ & SSV/SST \\
\hline 45 & 10,0 & 38.416 & 23.516 & 0,61 \\
85 & 10,0 & 23.124 & 15.426 & 0,67 \\
113 & 10,0 & 31.280 & 20.584 & 0,66 \\
150 & 10,0 & 40.152 & 26.412 & 0,66 \\
\hline
\end{tabular}

\subsubsection{Testes do bocal no reator piloto}

Para obter gradiente de velocidade em torno de $20 \mathrm{~s}^{-1}$ no interior do reator anaeróbio, o reservatório elevado foi instalado com nível médio de $1,76 \mathrm{~m}$ acima do nível d'água. $\mathrm{O}$ piezômetro instalado anteriormente ao bocal aferiu uma carga manométrica aplicada ao bocal de $0,98 \mathrm{~m}$, o que significa que a perda de carga do reservatório até a entrada do bocal foi de 0,78 m. Para essas condições, e vazão de descarga de $0,005 \mathrm{~m}^{3} \cdot \mathrm{s}^{-1}$, observou-se que o coeficiente de descarga do bocal foi de 0,82 (tempo de descarga médio $=30$ segundos), e velocidade média na saída do jato igual a $1,55 \mathrm{~m} \cdot \mathrm{s}^{-1}$. A velocidade teórica com que o jato se chocou na parede do reator foi de $0,37 \mathrm{~m} \cdot \mathrm{s}^{-1}$. Esses valores foram obtidos para reator com vazão média afluente de $2,6 \mathrm{~m}^{3} \cdot \mathrm{h}^{-1}$.

Nestas condições operacionais a potência média aplicada foi de 48,0 W $\left(2,7 \mathrm{~W} \cdot \mathrm{m}^{-3}\right)$, o que resultou em gradiente de velocidade de $16,6 \mathrm{~s}^{-1}$, durante o tempo de descarga.

Ressalta-se que o pequeno volume do reator, em relação aos reatores utilizados em estações de escala plena, possibilitou o uso de um reservatório pequeno onde foi possível considerar a perda de carga média (devido à pouca variação no nível do reservatório). Porém nas condições operacionais em grande escala, o volume do reservatório necessário e a diferença do nível de água máximo e mínimo deverá ser maior, o que demanda uma análise mais detalhada das velocidades e da dissipação de energia. 


\subsubsection{Monitoramento do sistema}

\subsubsection{Comentários gerais}

Os resultados dos ensaios físico-químicos foram exibidos em forma de gráficos, apresentando valores de entrada, saída e remoção para cada variável analisada. Os resultados foram apresentados separadamente para cada unidade do sistema piloto (reator e decantador), visando avaliar a importância de cada uma. Para melhor compreensão do sistema, destaca-se que a saída do reator e a entrada do decantador representam o mesmo ponto de amostragem. Em seguida foram apresentados os resultados globais do sistema (considerando-se a entrada do reator e a saída do decantador).

\subsubsection{Remoção de DQO de amostra bruta}

As remoções médias de DQO em cada etapa são apresentadas na Tabela 5.6. A grande descarga proporcionada pelo jato de entrada teve grande influência no arraste de sólidos da manta de lodo, sendo responsável pela maior concentração de DQO na saída do reator em relação à DQO de entrada, o que ressaltou a importância da unidade de decantação para o funcionamento do sistema. A DQO não foi mensurada para a terceira etapa (TDH $=8 \mathrm{~h}$ ) pois o período de duração foi muito curto e o sistema ainda estava perdendo grande quantia de sólidos suspensos, como será discutido no item 5.4.3.4.

Na Figura 5.6 são apresentados os valores de DQO de entrada e saída do reator, destacando que as concentrações de entrada sofreram pouca oscilação e não impactaram, portanto, nas concentrações de saída. 
Tabela 5.6: Remoção de DQO por unidade e por etapa.

\begin{tabular}{ccc}
\hline & Etapa & $\begin{array}{c}\text { Remoção média de DQO } \\
(\boldsymbol{\%})\end{array}$ \\
\hline \multirow{2}{*}{ Reator } & Ajustes iniciais & 0 \\
& $\mathrm{TDH}=12 \mathrm{~h}$ & 0 \\
\hline \multirow{2}{*}{ Decantador } & Ajustes iniciais & 48,17 \\
& $\mathrm{TDH}=12 \mathrm{~h}$ & 73,37 \\
\hline Sistema & Ajustes Iniciais & 30,07 \\
(reator + decantador) & TDH $=12$ horas & 52,79 \\
\hline
\end{tabular}

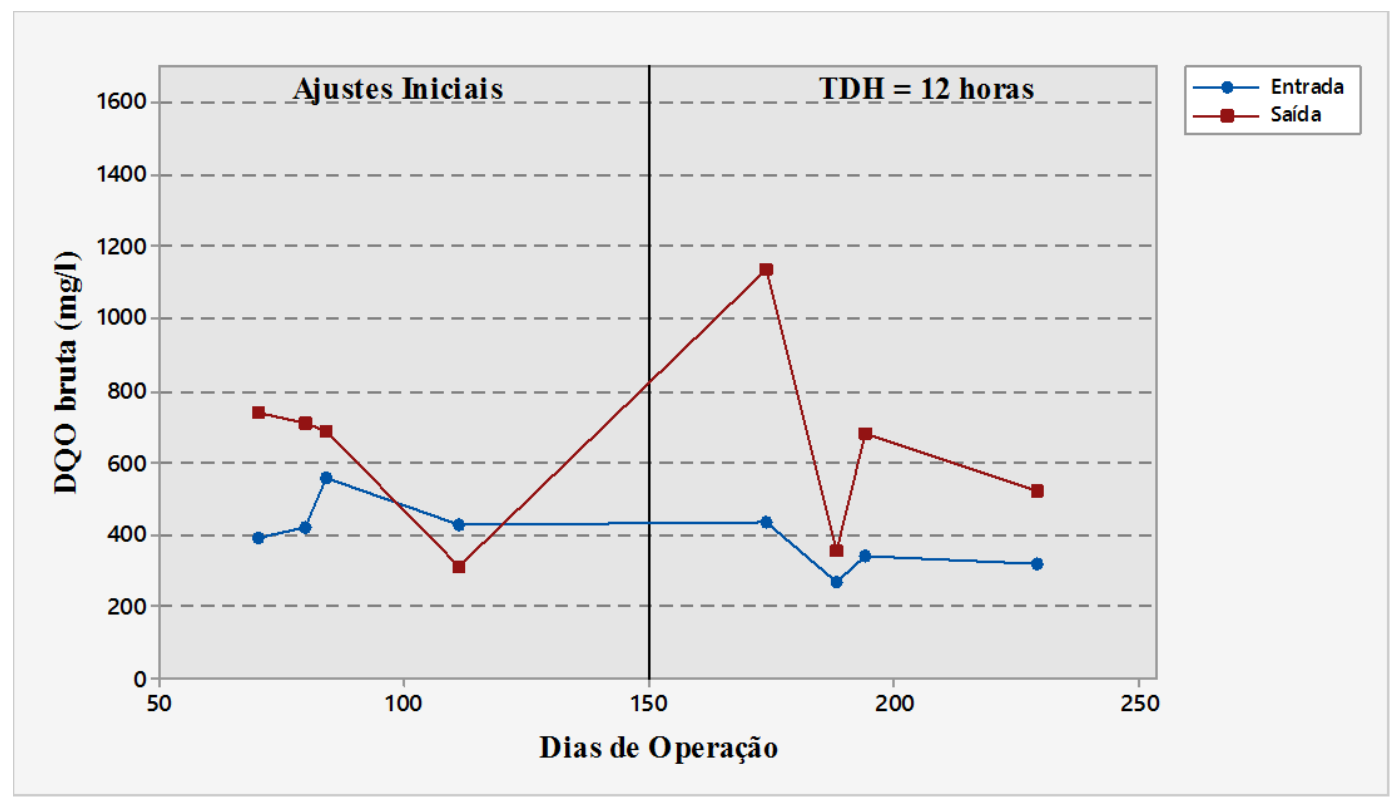

Figura 5.6: DQO das amostras brutas na entrada e saída do reator.

Na Figura 5.7 são apresentados os valores de DQO para entrada e saída do sistema de decantação. Durante a etapa de ajustes iniciais os valores de DQO na saída estiveram sempre abaixo de $400 \mathrm{mg}^{-1} \mathrm{l}^{-1}$, já na segunda etapa este desempenho foi melhor, não ocorrendo amostras acima de $200 \mathrm{mg} \cdot \mathrm{l}^{-1}$. 


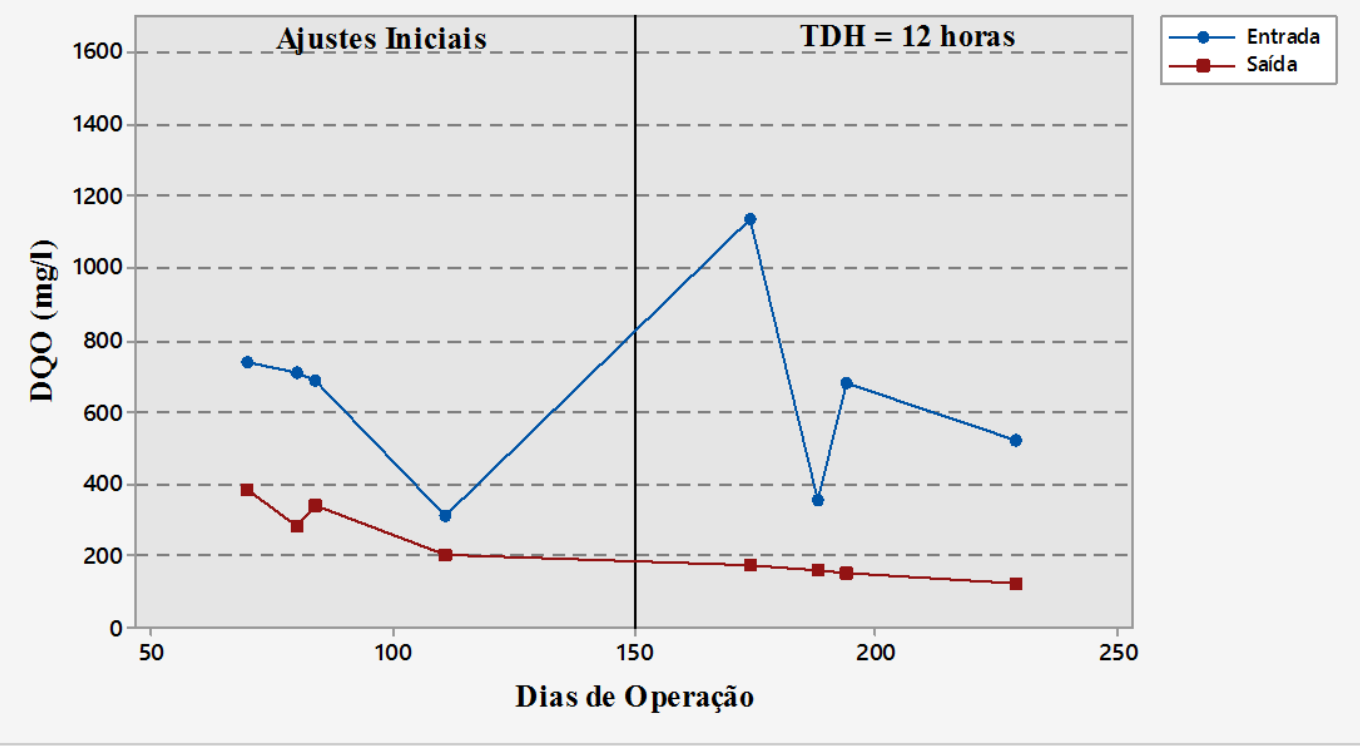

Figura 5.7: DQO das amostras brutas na entrada e saída do decantador de alta taxa.

Devido ao grande aporte de sólidos na segunda etapa (em decorrência da manta de lodo estar com maior expansão no período), as eficiências de remoção de DQO no decantador foram elevadas como pode ser notado na Figura 5.8.

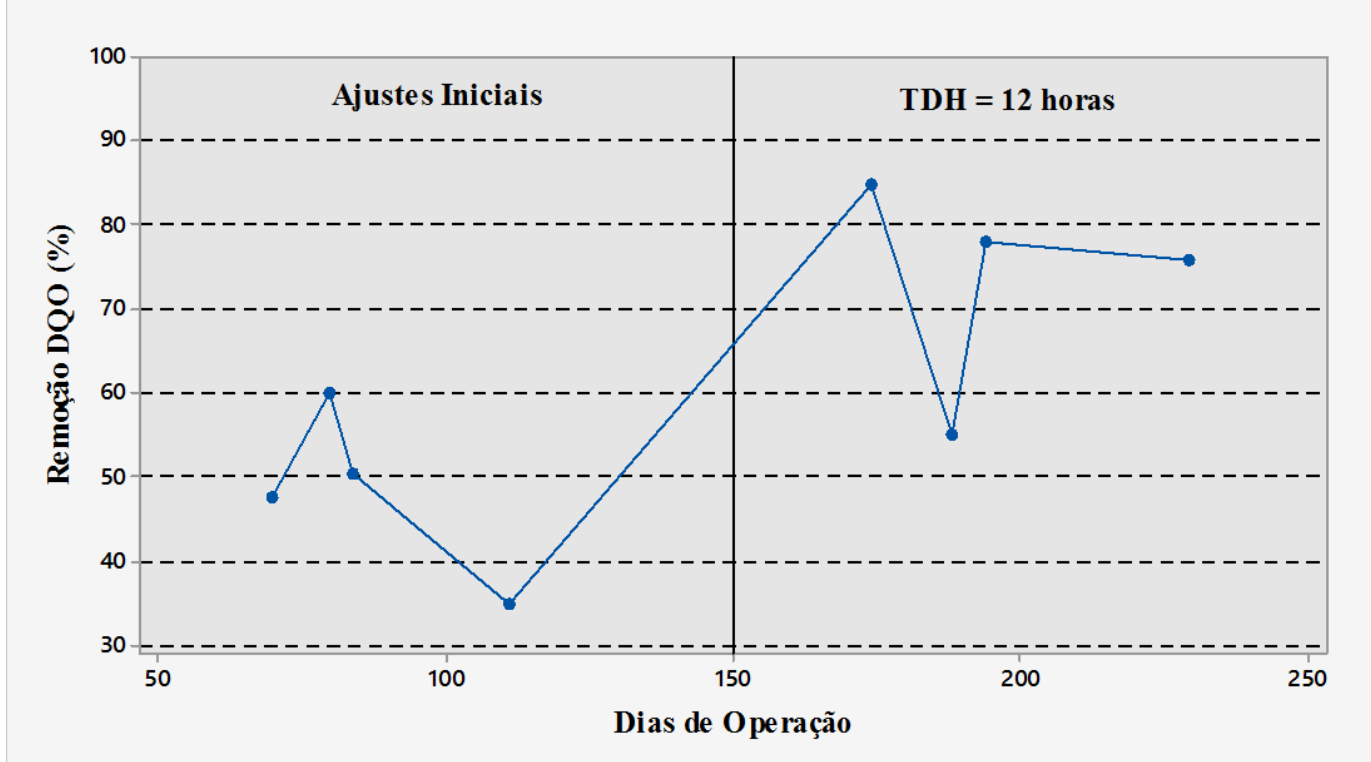

Figura 5.8: Eficiência de remoção de DQO no decantador de alta taxa.

Na Figura 5.9 são apresentados os valores de DQO na entrada e saída do sistema, e na Figura 5.10 são expostos os valores das respectivas eficiências. No período de ajustes iniciais houve grande variação nos valores de saída devido, principalmente, ao arraste de lodo junto ao 
efluente. Esse arraste provavelmente ocorreu em virtude das reinoculações a que o reator foi submetido.

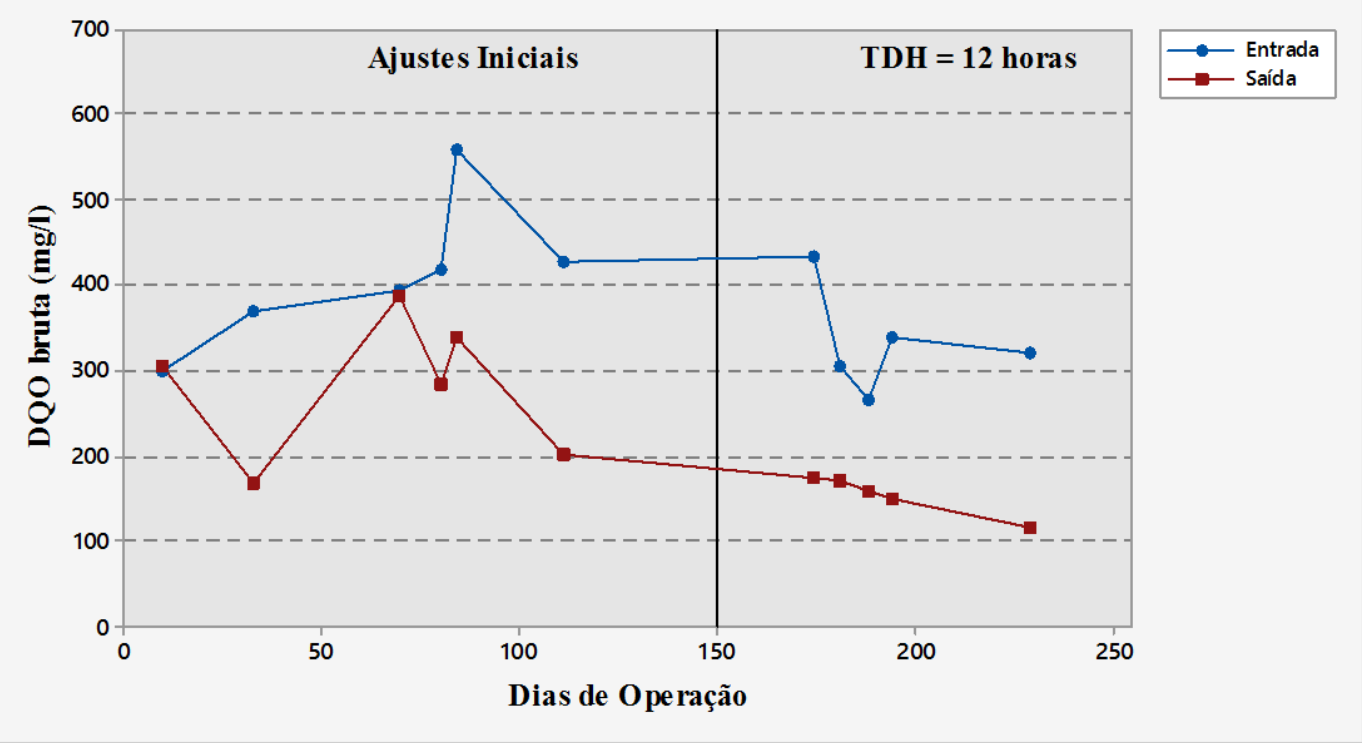

Figura 5.9: DQO das amostras brutas na entrada e saída do sistema piloto.

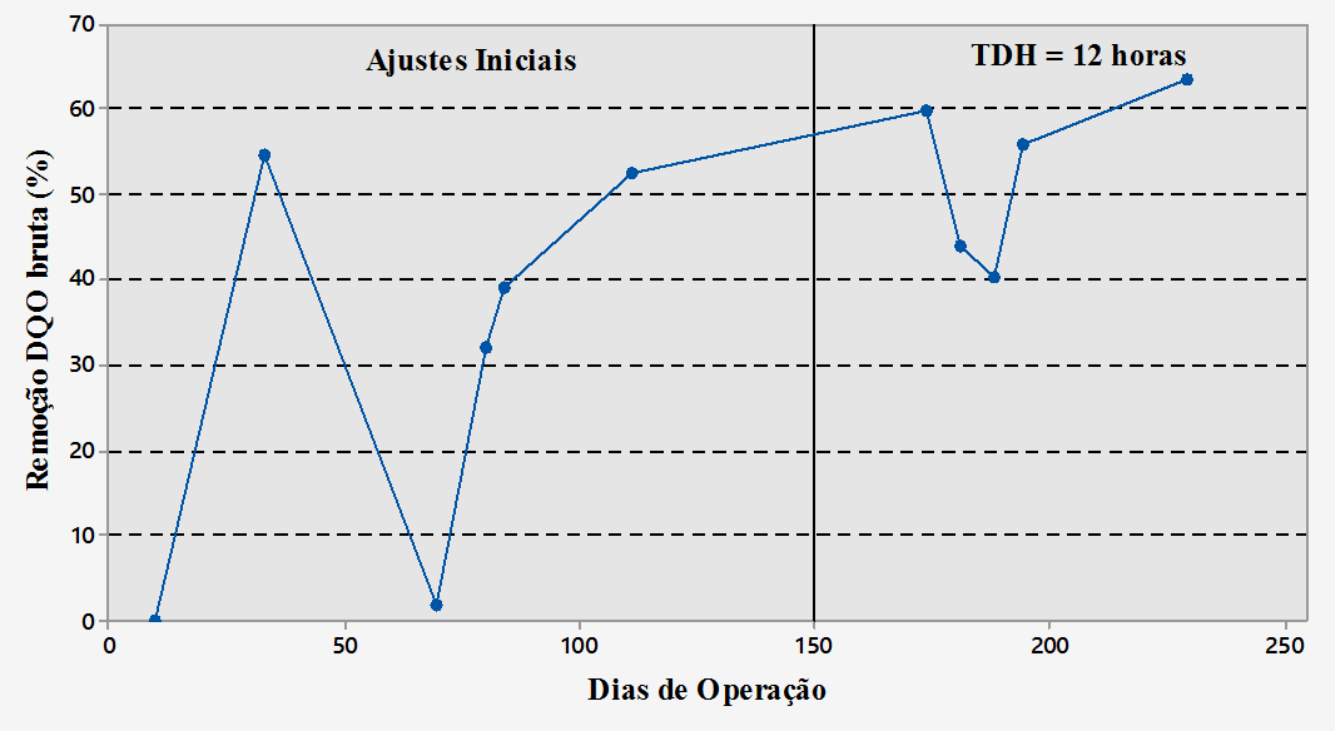

Figura 5.10: Eficiência de remoção de DQO pelo sistema piloto.

A eficiência de remoção de DQO bruta quando o sistema passou a ser operado com TDH de 12 horas foi de $52,79 \%$. O principal fator para o sistema não ter atingido maior eficiência foi atribuído à baixa concentração de matéria orgânica no esgoto afluente. Haja vista 
que todos valores de saída foram inferiores a $200 \mathrm{mg} \cdot \mathrm{l}^{-1}$ nessa etapa da pesquisa, o desempenho foi considerado satisfatório.

\subsubsection{Remoção de DQO de amostra filtrada}

A avaliação da concentração DQO da amostra filtrada se faz importante uma vez que é possível a análise da degradação do efluente sem levar em consideração a influência da parcela de sólidos presentes. Na Tabela 5.7 são apresentadas as eficiências médias de remoção para cada etapa operacional.

Tabela 5.7: Remoção de DQO de amostra filtrada por unidade e por etapa.

\begin{tabular}{ccc}
\hline Etapa & $\begin{array}{c}\text { Remoção média de DQO } \\
\text { de amostra filtrada } \\
(\boldsymbol{\%})\end{array}$ \\
\hline \multirow{2}{*}{ Reator } & Ajustes iniciais & 57,45 \\
& $\mathrm{TDH}=12 \mathrm{~h}$ & 60,47 \\
& $\mathrm{TDH}=8 \mathrm{~h}$ & 64,97 \\
Decantador & Ajustes iniciais & 25,10 \\
& $\mathrm{TDH}=12 \mathrm{~h}$ & 13,47 \\
Sistema & $\mathrm{TDH}=8 \mathrm{~h}$ & 24,13 \\
\hline (reator + decantador) & Ajustes Iniciais & 68,63 \\
& $\mathrm{TDH}=12 \mathrm{~h}$ & 67,09 \\
& $\mathrm{TDH}=8 \mathrm{~h}$ & 75,20 \\
\hline
\end{tabular}

Os valores de DQO de amostras filtradas na entrada e saída do reator são apresentados na Figura 5.11. A etapa de ajustes iniciais foi a única que ultrapassou a faixa de $100 \mathrm{mg} \cdot \mathrm{l}^{-1} \mathrm{na}$ saída. Nas demais etapas os valores de DQO de saída estiveram abaixo deste valor. Na Figura 5.12 são apresentadas as eficiências de remoção para cada amostra de DQO filtrada. Destacase que os valores de eficiências estão diretamente ligados com os valores de DQO filtrada na entrada. 


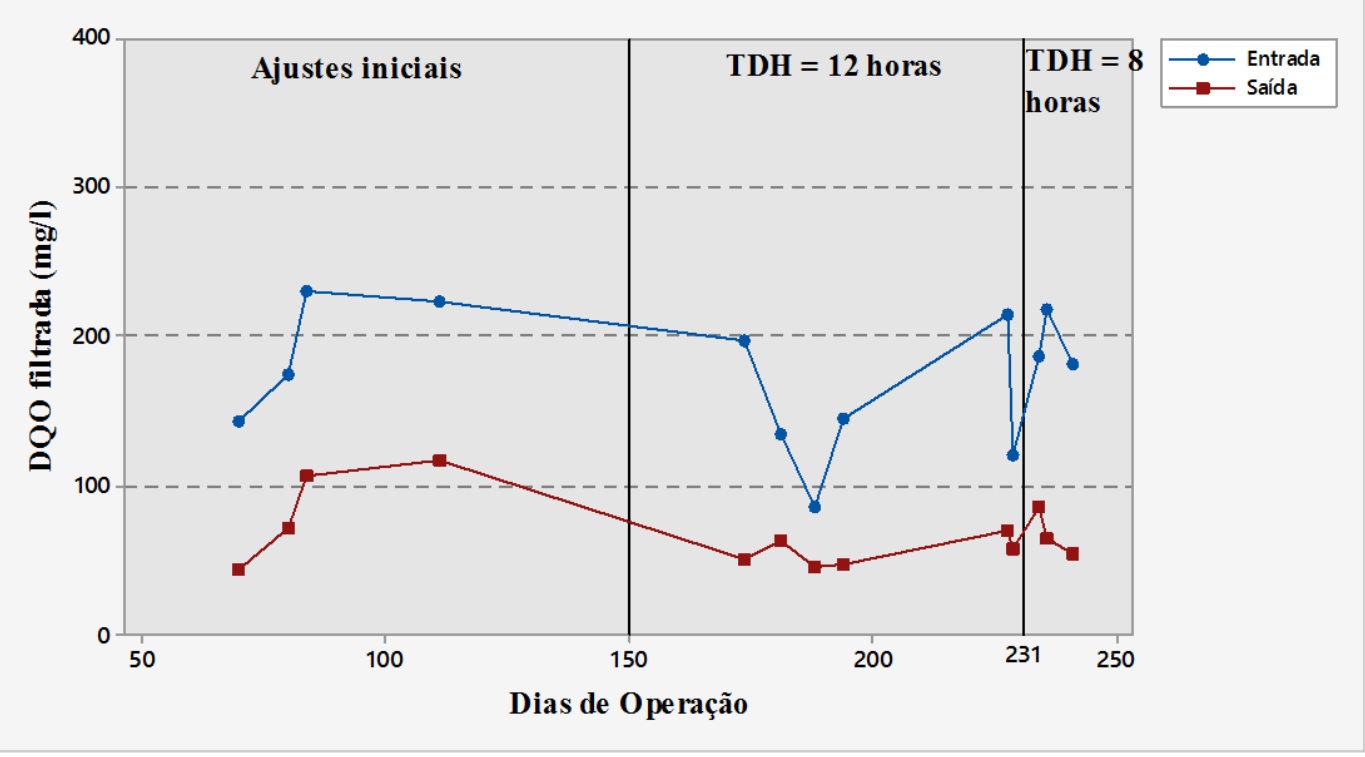

Figura 5.11: Valores de DQO de amostras filtradas na entrada e saída do reator.

Na Figura 5.12 observa-se também a semelhança de eficiências de remoção de DQO nas três etapas. Observa-se que a eficiência nas três etapas estiveram entre, aproximadamente, 50 e $70 \%$.

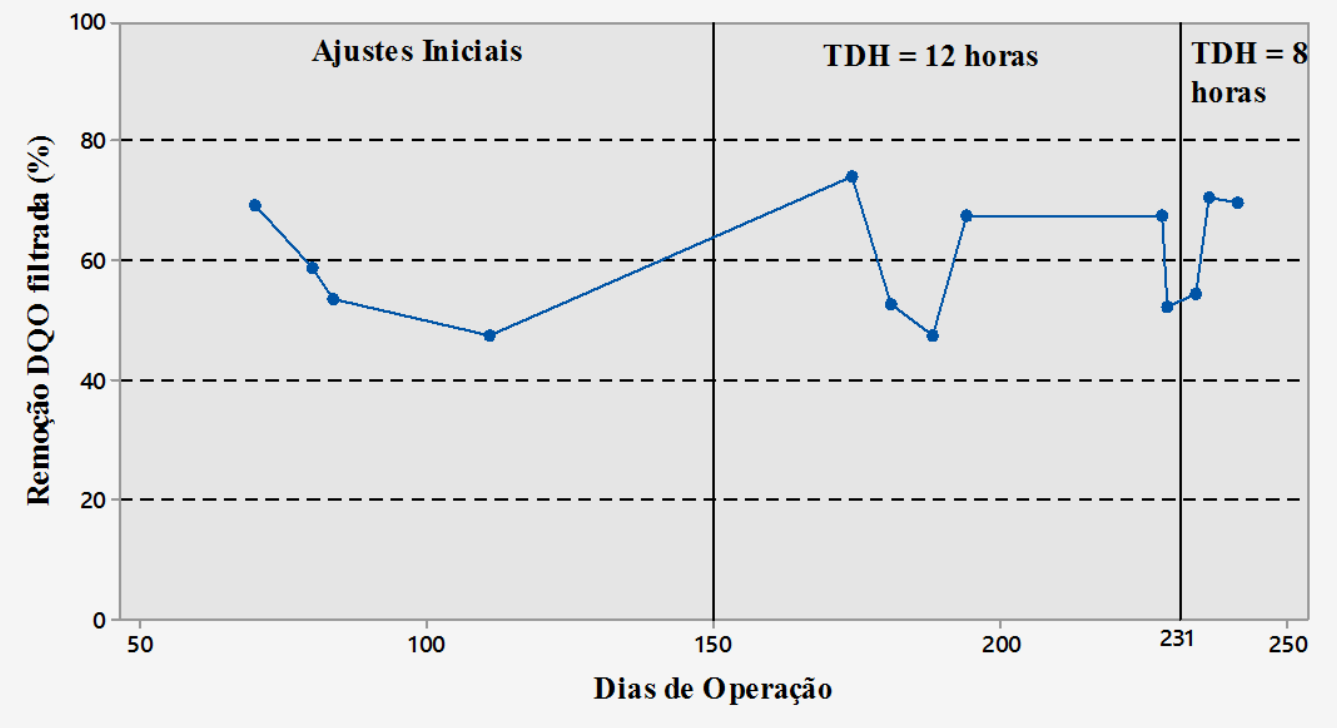

Figura 5.12: Eficiência de remoção de DQO de amostra filtrada no reator.

Na Figura 5.13 são apresentados os valores de concentração de DQO filtrada para entrada e saída do decantador. Em sua maioria, os pontos deste gráfico mostram que os valores de entrada e de saída de DQO filtrada mantiveram-se próximos. 


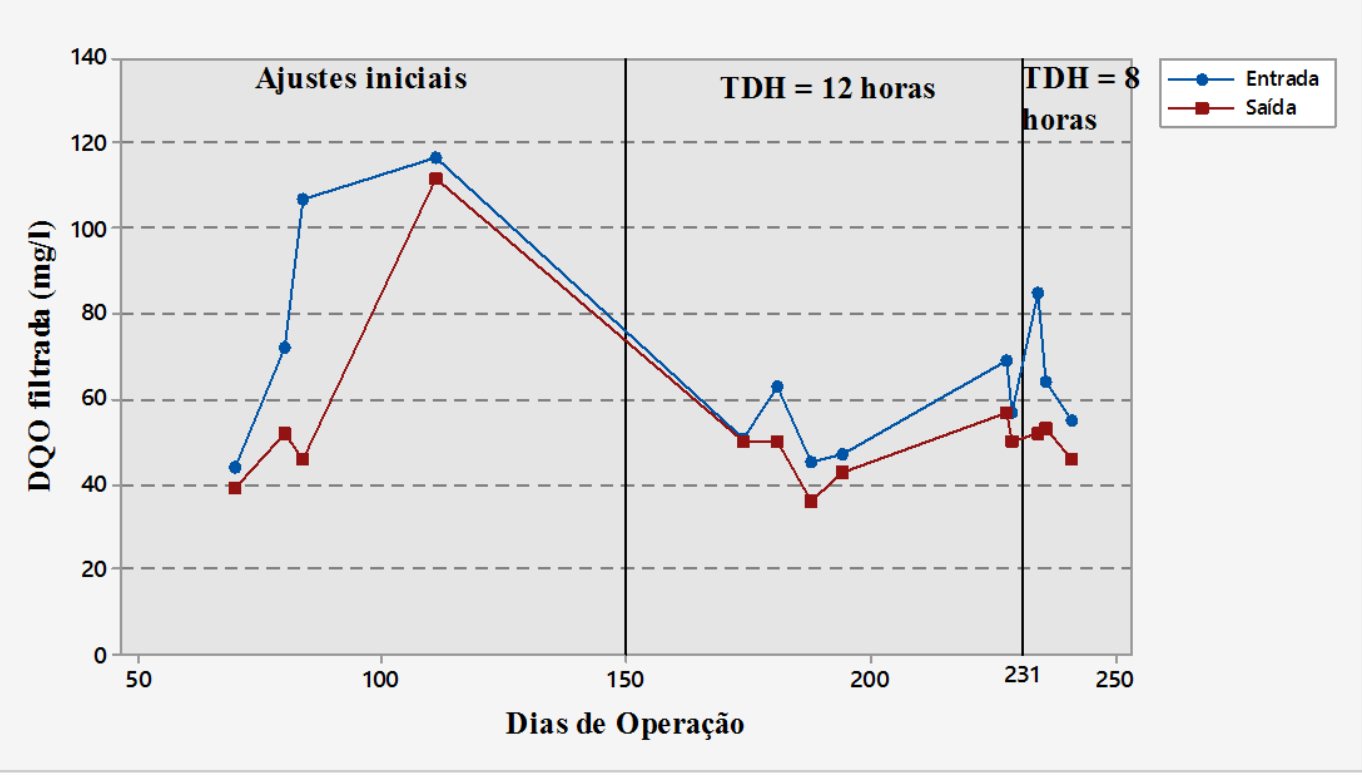

Figura 5.13: Valores de DQO de amostra filtrada na entrada e saída do decantador.

Na Figura 5.14 constata-se que houve baixa remoção de DQO de amostras filtradas no decantador. Todos os pontos apresentaram remoção de DQO abaixo de $40 \%$, com exceção do terceiro ponto na etapa de ajustes iniciais.

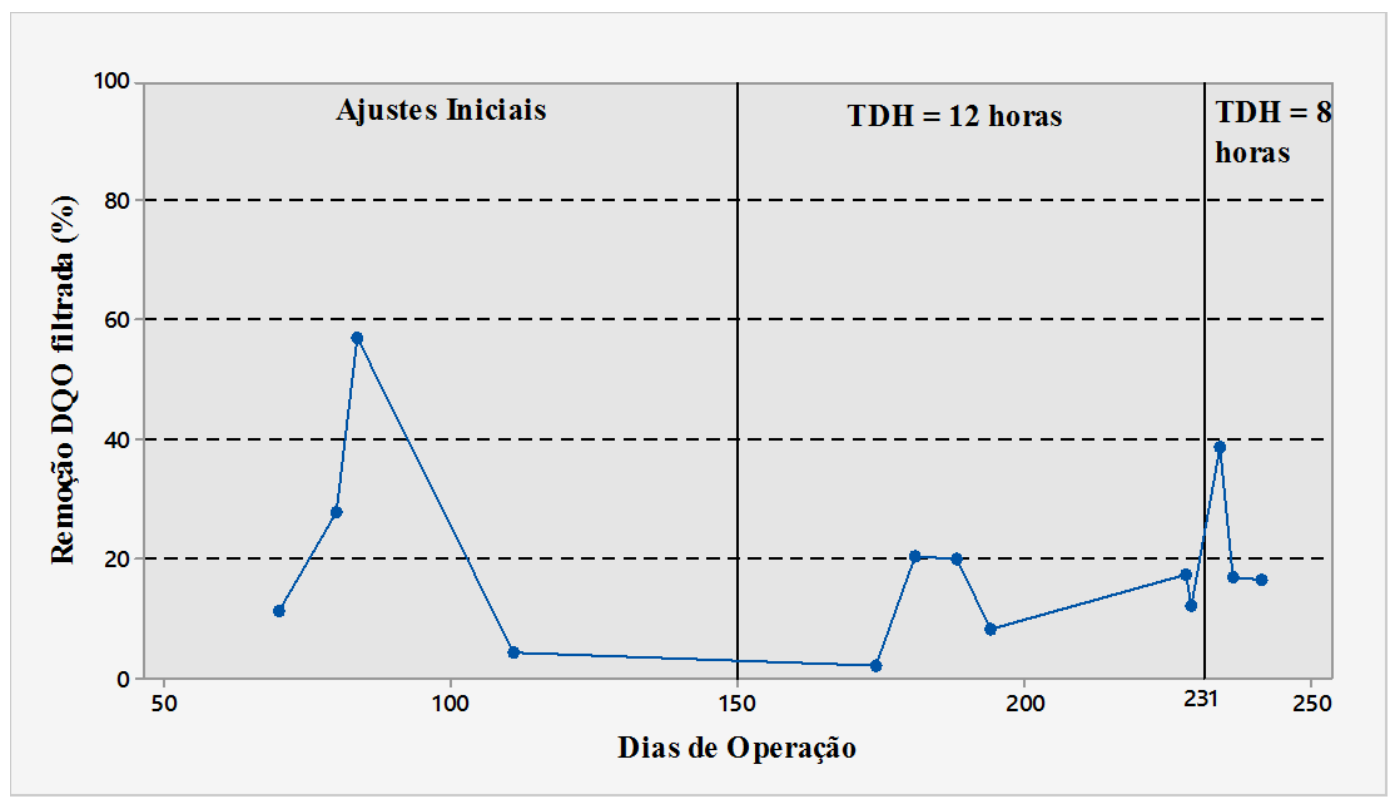

Figura 5.14: Eficiência de remoção de DQO de amostra filtrada no decantador.

Na Figura 5.15 são apresentados os valores de concentração DQO filtrada para entrada e saída do sistema global. Houve de modo geral, valores de saída semelhante de DQO filtrada 
em todas as etapas, o que demonstra a importância de implantação do decantador após o reator anaeróbio.

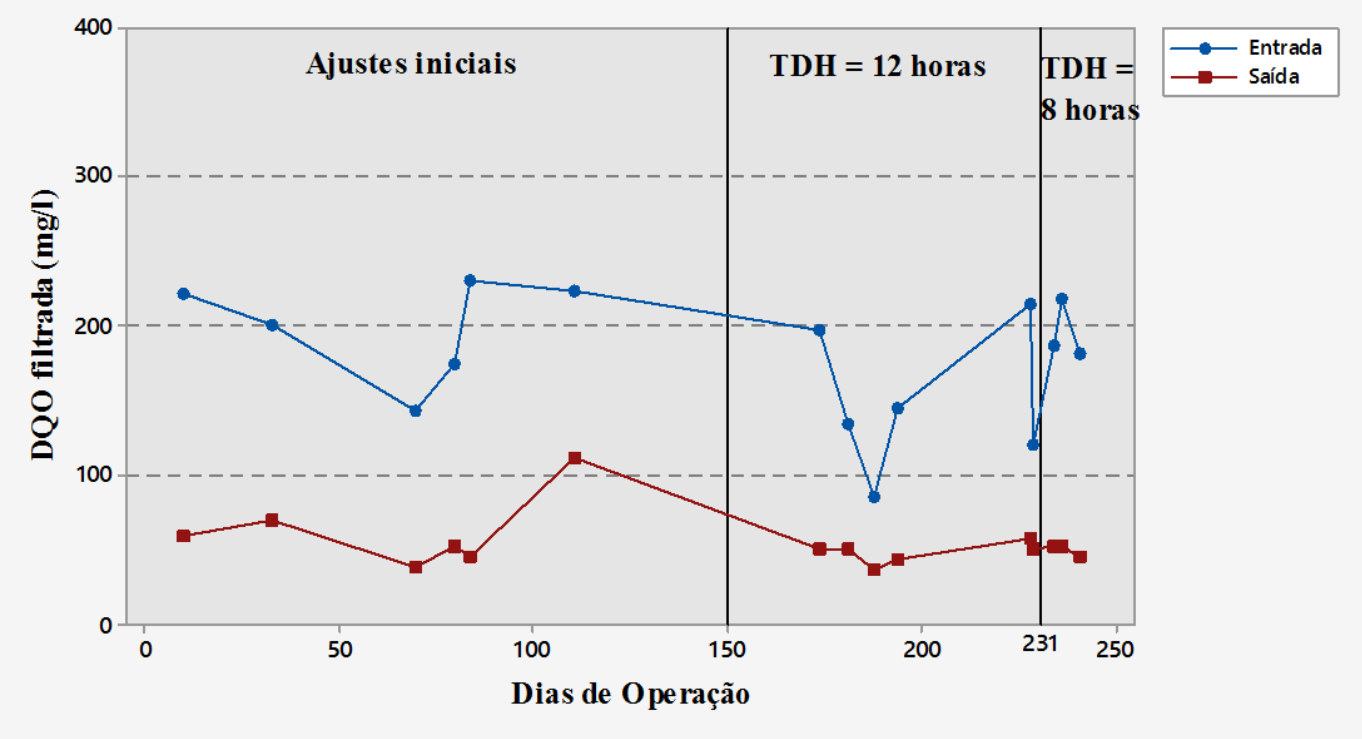

Figura 5.15: Valores de DQO de amostra filtrada na entrada e saída do sistema global.

Na Figura 5.16 constata-se que houve boa remoção de DQO filtrada no sistema global. Todos os pontos apresentaram remoção de DQO acima de 50\%, com destaque para as remoções da terceira etapa (TDH de 8 horas) com média de 75,20\%.

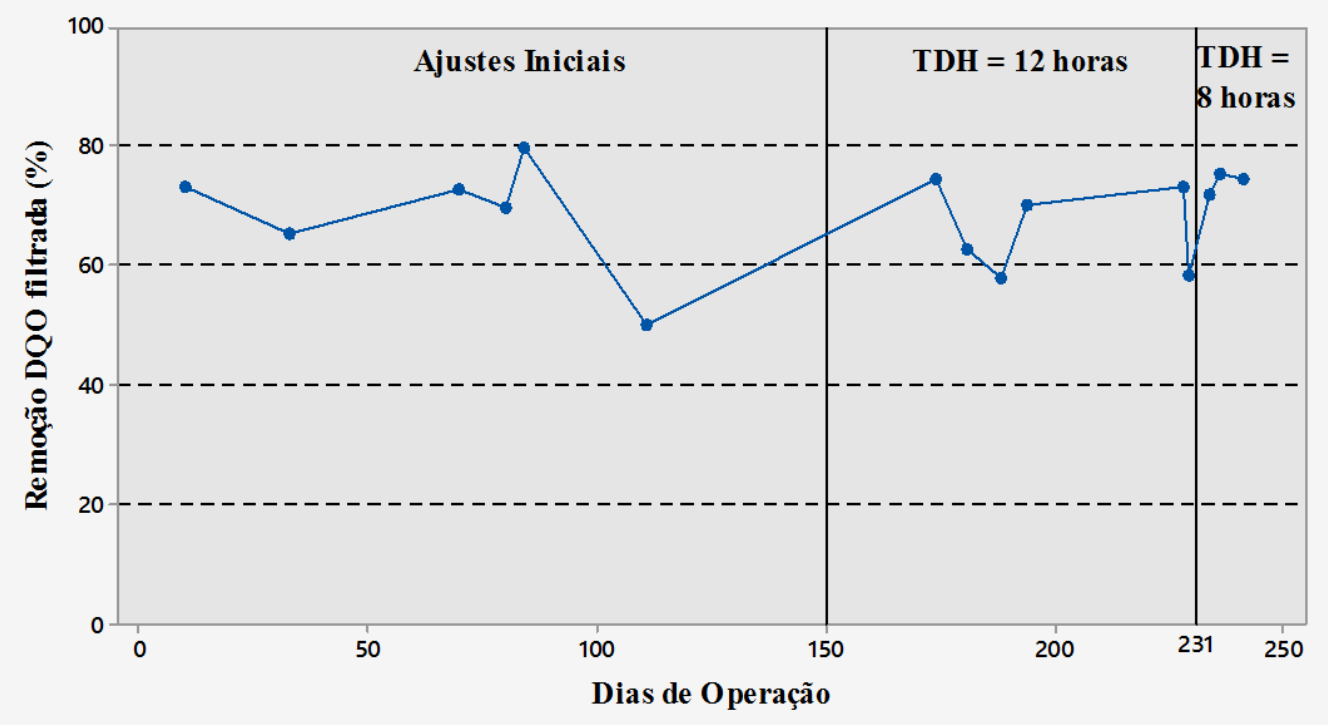

Figura 5.16: Eficiência de remoção de DQO de amostras filtradas no sistema global. 
Ao comparar as remoções médias de DQO das amostras filtradas para o sistema global observa-se valores muito próximos para a etapa de ajustes iniciais (quando novas parcelas de lodo biológico eram adicionados frequentemente) e para as duas etapas seguintes. Dessa forma, supõe-se que a biomassa esteve apta para remover matéria orgânica desde o princípio de operação do reator.

\subsubsection{Remoção de $\mathrm{DBO}$}

A análise de DBO foi realizada somente para etapa de operação com TDH de 12 horas, apresentando bons resultados para o sistema piloto, como pode ser observado nas médias de remoção apresentadas na Tabela 5.8

Tabela 5.8: Remoção de DBO por unidade e por etapa.

\begin{tabular}{ccc}
\hline Eeator & Etapa & $\begin{array}{c}\text { Remoção média de DBO } \\
(\%)\end{array}$ \\
\hline TDH $=12 \mathrm{~h}$ & 6,40 \\
\hline Decantador & $\mathrm{TDH}=12 \mathrm{~h}$ & 74,04 \\
\hline Sistema & $\mathrm{TDH}=12 \mathrm{~h}$ & 70,90 \\
\hline
\end{tabular}

Os valores de DBO na entrada e saída do reator estão apresentados na Figura 5.17. Devido aos valores de DBO na saída superarem os de DBO na entrada, a remoção média foi praticamente nula. Os altos valores na saída do reator são atribuídos ao grande arraste de sólidos proporcionados pela alimentação por jatos. 


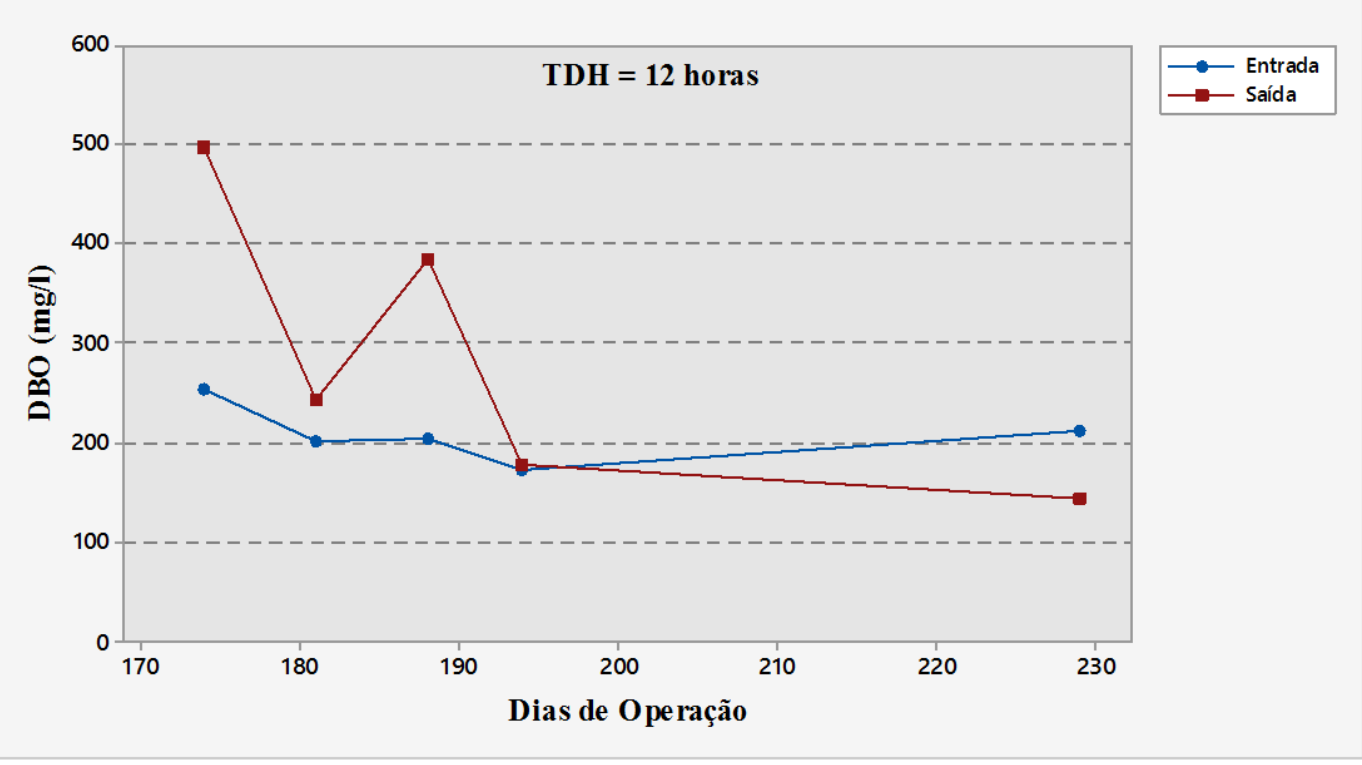

Figura 5.17: Valores de DBO na entrada e saída do reator.

Na Figura 5.18 são apresentados os valores de DBO para entrada e saída do decantador. Observa-se que os valores de saída do decantador mantiveram-se abaixo de $100 \mathrm{mg} . \mathrm{l}^{-1}$ independente da concentração de DBO na entrada.

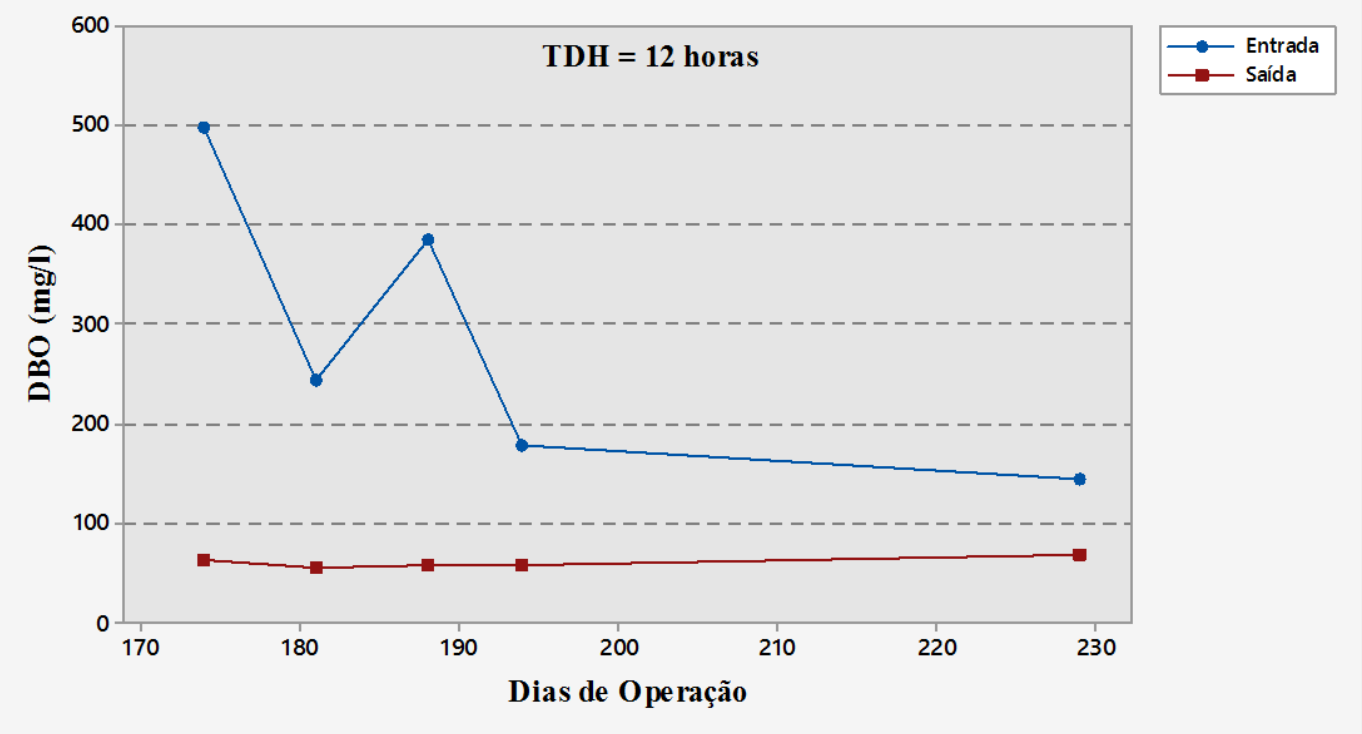

Figura 5.18: Valores de DBO na entrada e saída do decantador.

Ao observar Figura 5.19, constata-se que houve elevada remoção de DBO no decantador. A eficiência de remoção de DBO no decantador, neste caso, está diretamente ligada com a concentração de entrada, pois verifica-se na Figura 5.18 que o valor na saída aproxima- 
se de um valor constante. Para os três primeiros pontos (elevada concentração de entrada) houve uma eficiência de, aproximadamente, $80 \%$ e para os dois últimos pontos (baixa concentração de entrada) a eficiência ficou entre 50 e $70 \%$.

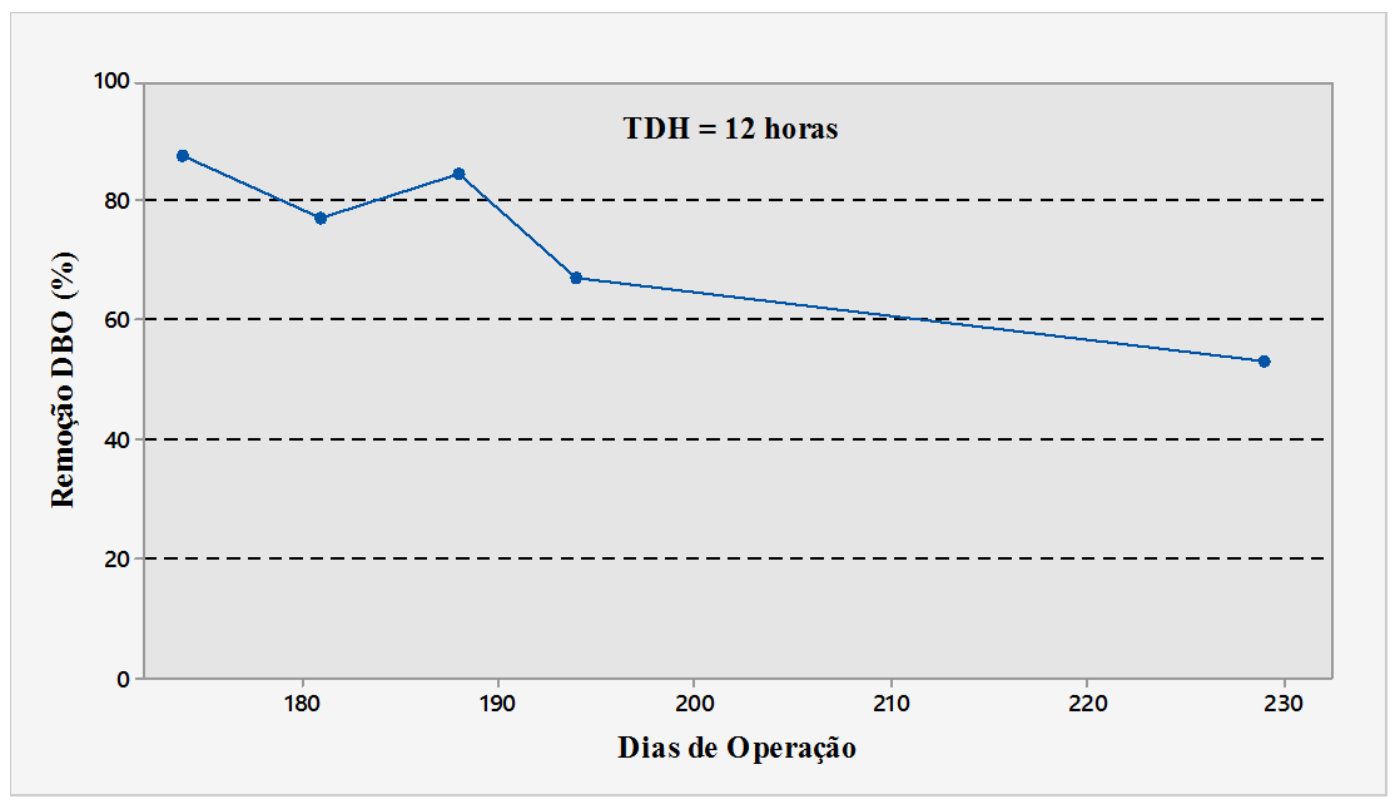

Figura 5.19: Eficiência de remoção de DBO no decantador.

Na Figura 5.20 são apresentados os valores de DBO para entrada e saída do sistema global. Observa-se que os valores de saída do sistema global mantiveram-se abaixo de $75 \mathrm{mg} . \mathrm{l}^{-}$ ${ }^{1}$ independente da DBO na entrada.

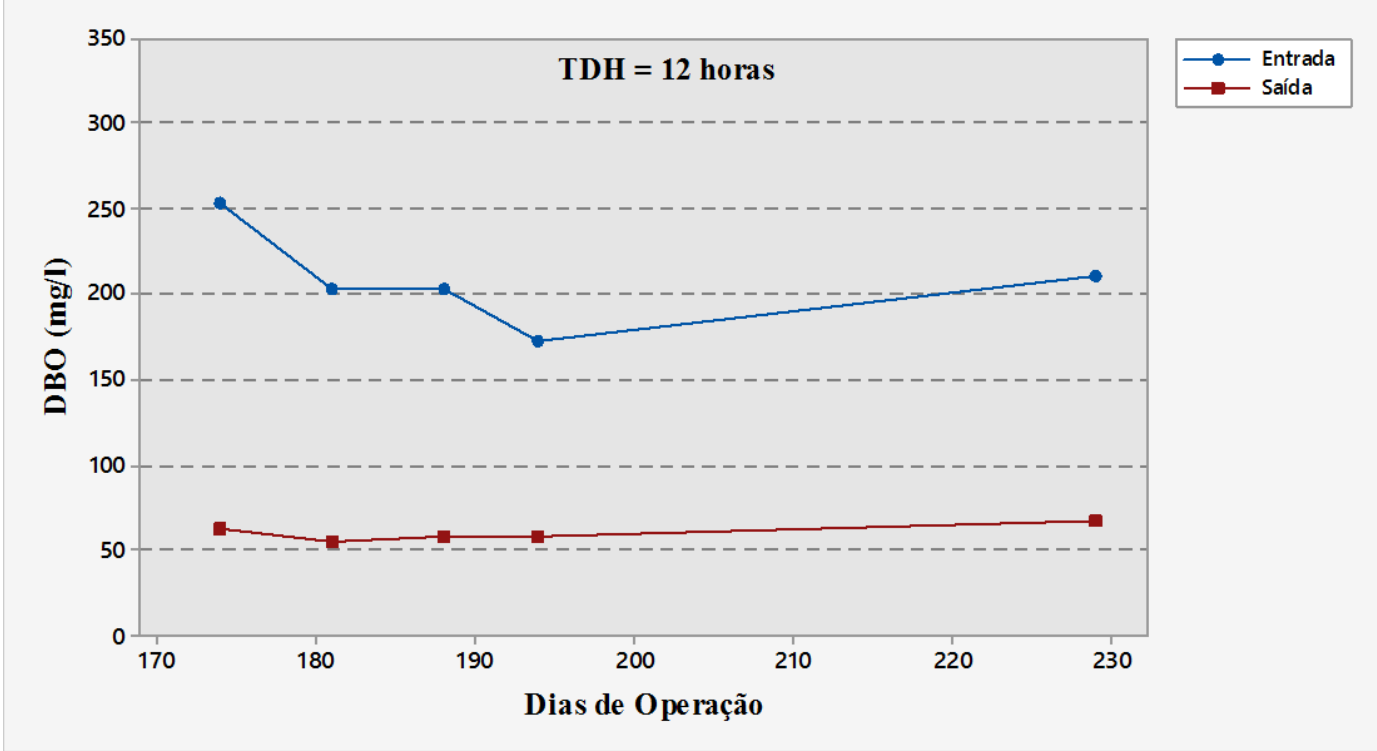

Figura 5.20: Valores de DBO na entrada e saída do sistema global. 
Na Figura 5.21 constata-se que houve elevada remoção de DBO no sistema global. Mesmo não havendo remoção significativa de DBO no reator, o sistema global se comportou de maneira satisfatória pois a remoção de DBO no decantador foi elevada $(74,04 \%)$, dessa forma o sistema global apresentou uma remoção de 70,90\%.

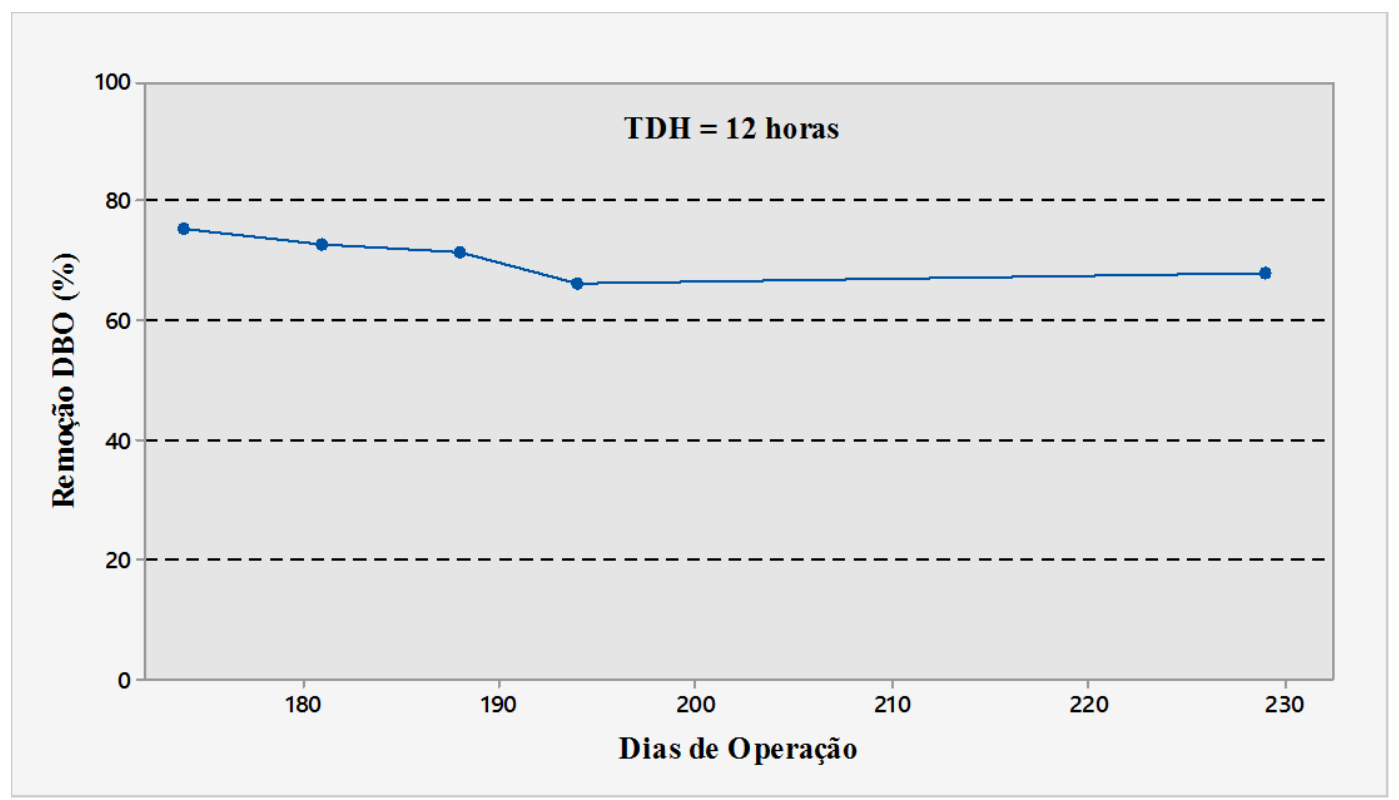

Figura 5.21: Eficiência de remoção de DBO no sistema global.

\subsubsection{Remoção de SST}

A grande agitação proporcionada pelos jatos intermitentes no período de descarga foi responsável por arrastar grande parcelas de lodo junto ao efluente. Essa situação fica evidente ao se observar os dados de remoção média de SST exibidos na Tabela 5.9, onde a remoção por parte do reator anaeróbio foi considerada nula.

Os valores de concentração de SST na entrada e saída do reator estão apresentados na Figura 5.22. Observa-se que os valores de concentração de SST na saída foram superiores, em todos os pontos, aos de entrada. Isto se deve ao arraste de lodo ocorrido durante a passagem do efluente pelo reator, carreando consigo os sólidos contidos na manta de lodo.

Nota-se que para este caso não há eficiência na remoção de SST, pois os valores de saída ultrapassam os valores de entrada. 
Tabela 5.9: Remoção de SST por unidade e por etapa.

\begin{tabular}{ccc}
\hline & Etapa & $\begin{array}{c}\text { Remoção média de SST } \\
(\boldsymbol{\%})\end{array}$ \\
\hline \multirow{3}{*}{ Reator } & Ajustes iniciais & 0 \\
& $\mathrm{TDH}=12 \mathrm{~h}$ & 0 \\
& $\mathrm{TDH}=8 \mathrm{~h}$ & 0 \\
\hline \multirow{2}{*}{ Decantador } & Ajustes iniciais & 61,30 \\
& $\mathrm{TDH}=12 \mathrm{~h}$ & 89,32 \\
& $\mathrm{TDH}=8 \mathrm{~h}$ & 80,43 \\
\hline Sistema & Ajustes Iniciais & 16,04 \\
(reator + decantador) & TDH $=12 \mathrm{~h}$ & 47,00 \\
& TDH $=8 \mathrm{~h}$ & 16,60 \\
\hline
\end{tabular}

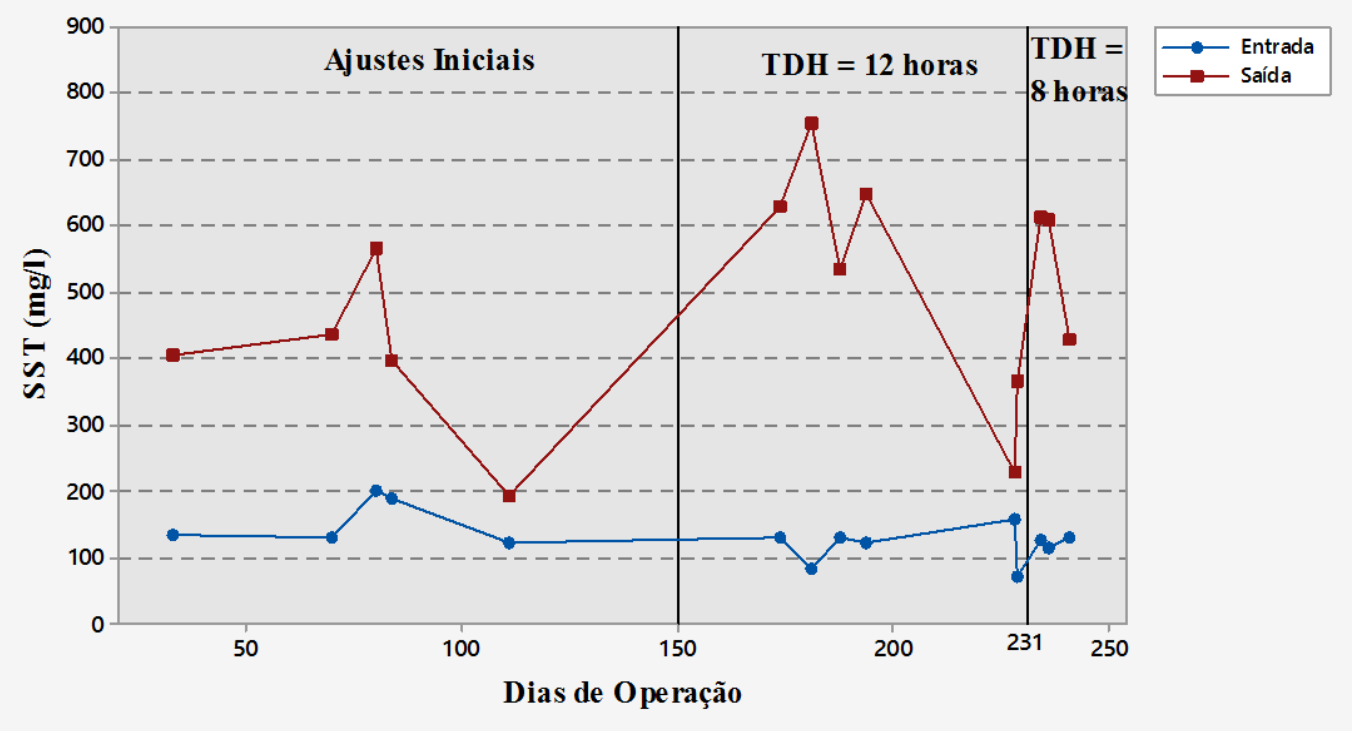

Figura 5.22: Concentrações de SST na entrada e saída do reator.

Na Figura 5.23 são apresentados os valores de concentração SST para entrada e saída do decantador. Observa-se que os valores de concentração de SST na saída do decantador mantiveram-se abaixo de $200 \mathrm{mg} \cdot \mathrm{l}^{-1}$ nas etapas de operação contínua. 


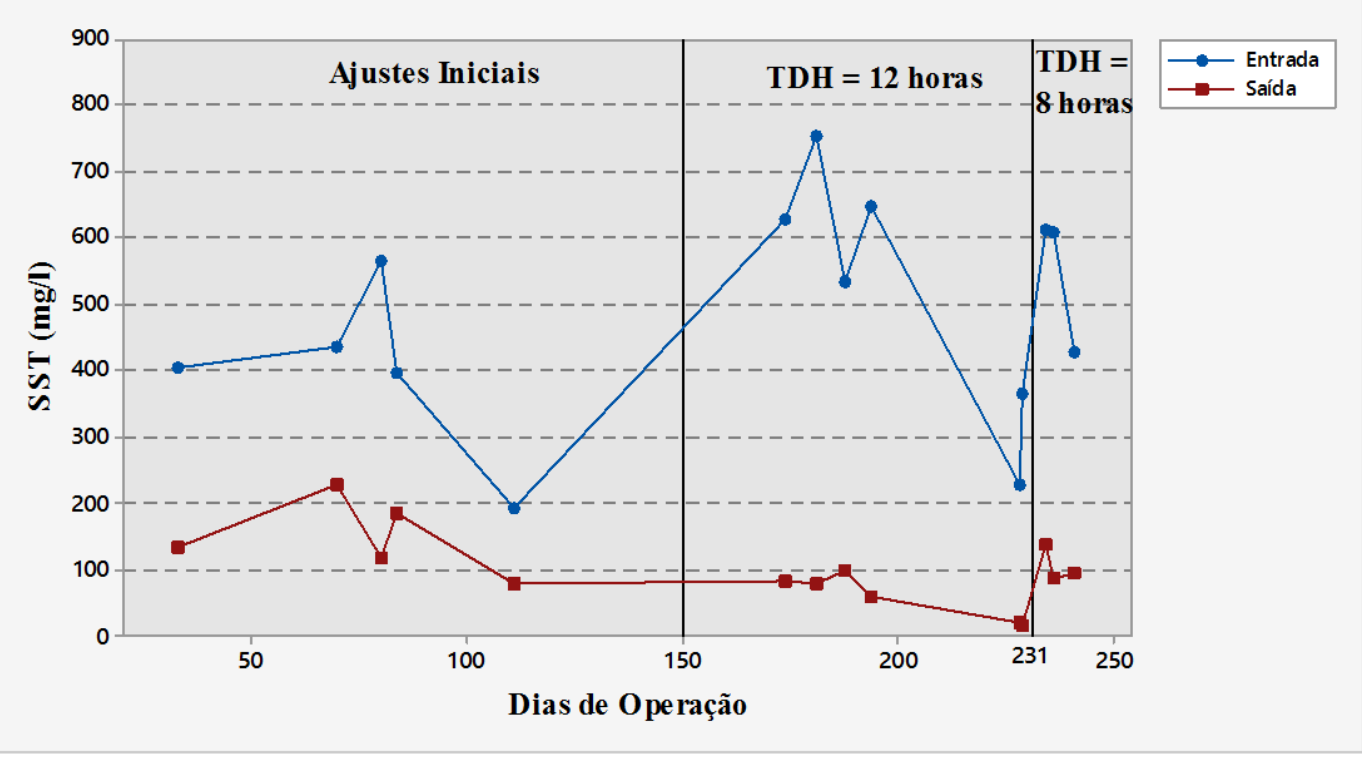

Figura 5.23: Concentrações de SST na entrada e saída do decantador.

Na Figura 5.24 constata-se que, com exceção da faixa de ajustes iniciais, a eficiência da remoção de SST manteve-se acima de 75\%, resultado que, somado ao cenário relacionado com baixas concentrações de saída do sistema (Figura 5.23), atestam a viabilidade do uso deste sistema para a remoção dos sólidos.

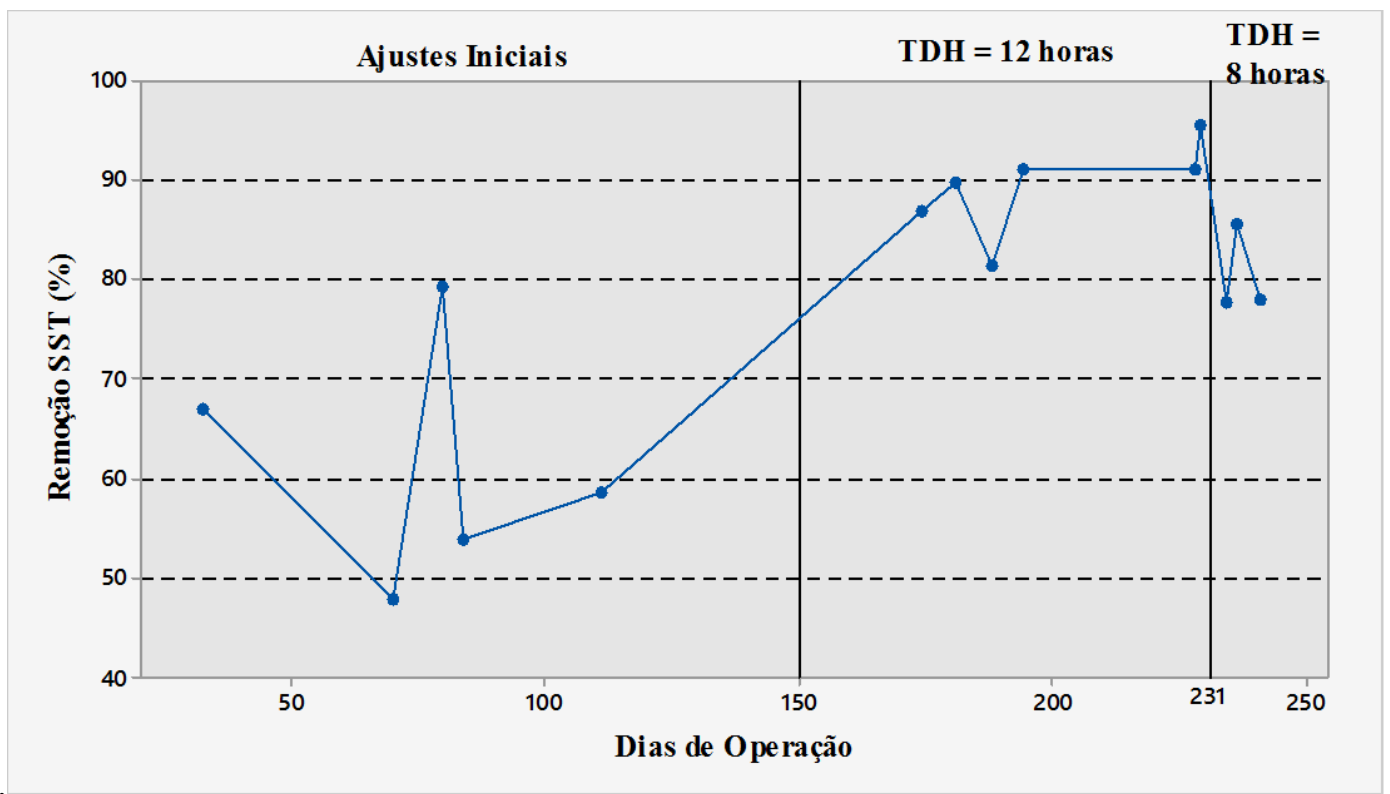

Figura 5.24: Eficiência de remoção de SST no decantador. 
Na Figura 5.25 são apresentados os valores de concentração SST para entrada e saída do sistema. Observa-se que os valores de saída e de entrada do sistema global não apresentam um padrão.

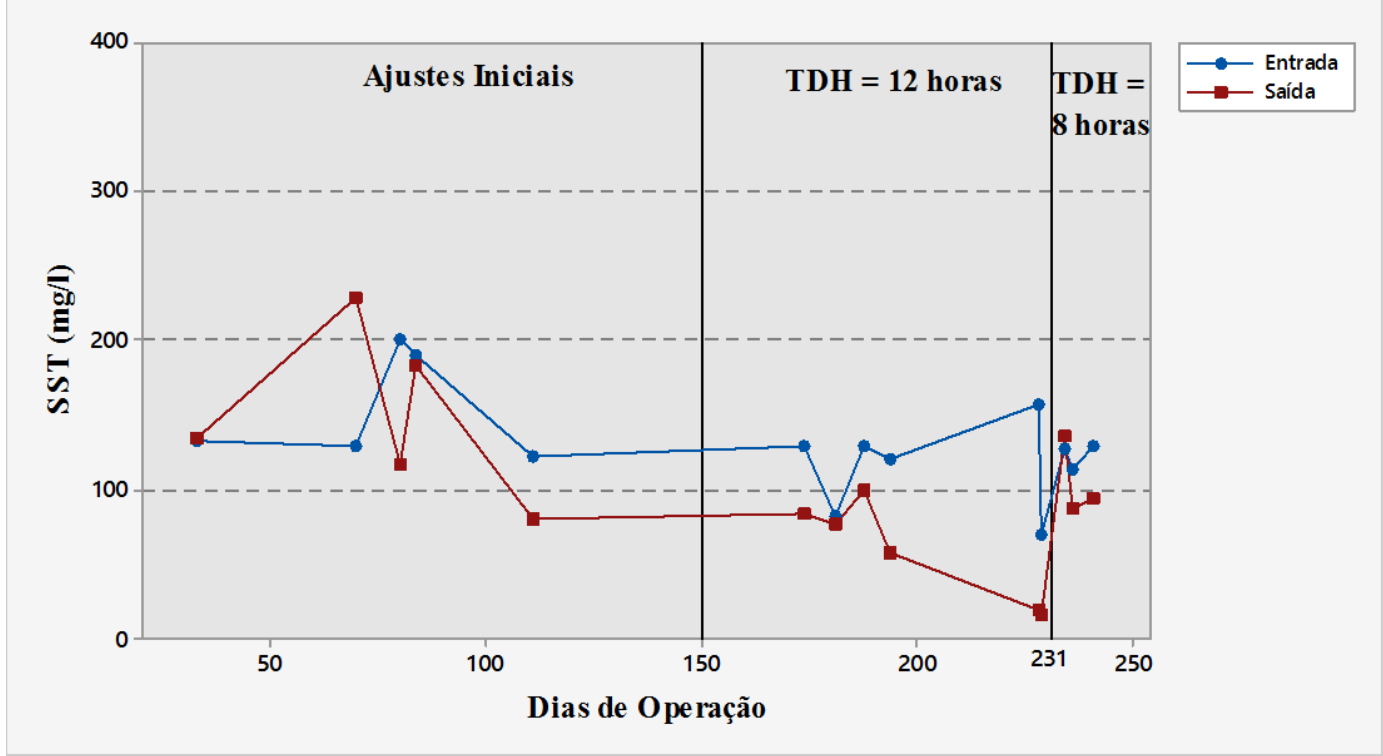

Figura 5.25: Concentrações de SST na entrada e saída do sistema.

Na Figura 5.26 observa-se que, em geral, a eficiência de remoção de SST do sistema global ficou em torno de $40 \%$. Esta baixa eficiência pode ser explicada pelo carreamento de lodo do reator para o decantador e pela grande variação nas concentrações de sólidos da entrada

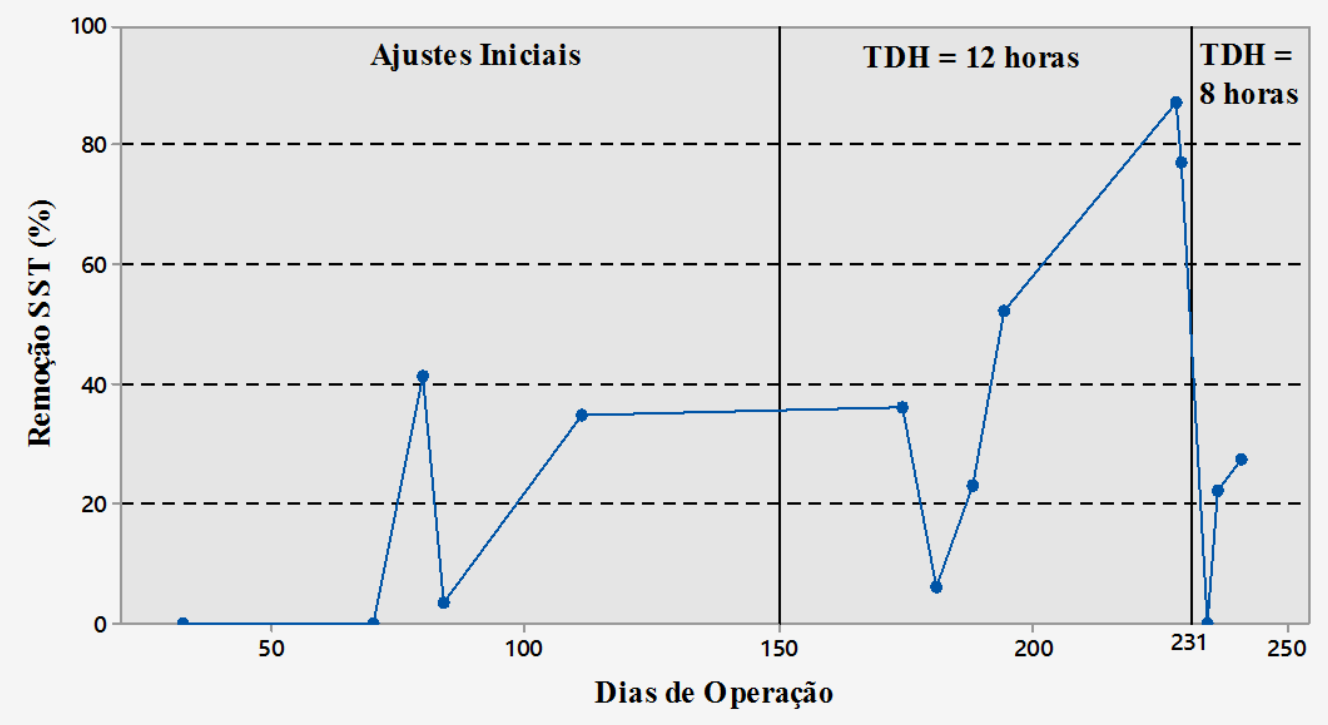

Figura 5.26: Eficiência de remoção de SST no sistema global. 


\subsubsection{5 $\mathrm{pH}$}

$\mathrm{O}$ valor de $\mathrm{pH}$ tem influência na diversidade microbiana e na cinética das reações químicas que ocorrem durante o tratamento, sendo um parâmetro muito importante para caracterizar o equilíbrio do processo. Segundo van Haandel e Lettinga (1994), no tratamento de esgoto doméstico o pH se mantêm na faixa ótima $(6,8$ - 7,2) de tratamento, na grande maioria dos casos. Na Figura 5.27 nota-se que os valores de pH na entrada e saída do reator ficaram próximas a essa faixa ótima, em geral. Destaca-se que em algumas amostras o valor do $\mathrm{pH}$ de saída esteve acima do $\mathrm{pH}$ de entrada, mostrando eficiência na remoção da acidez (AGV) por parte do reator.

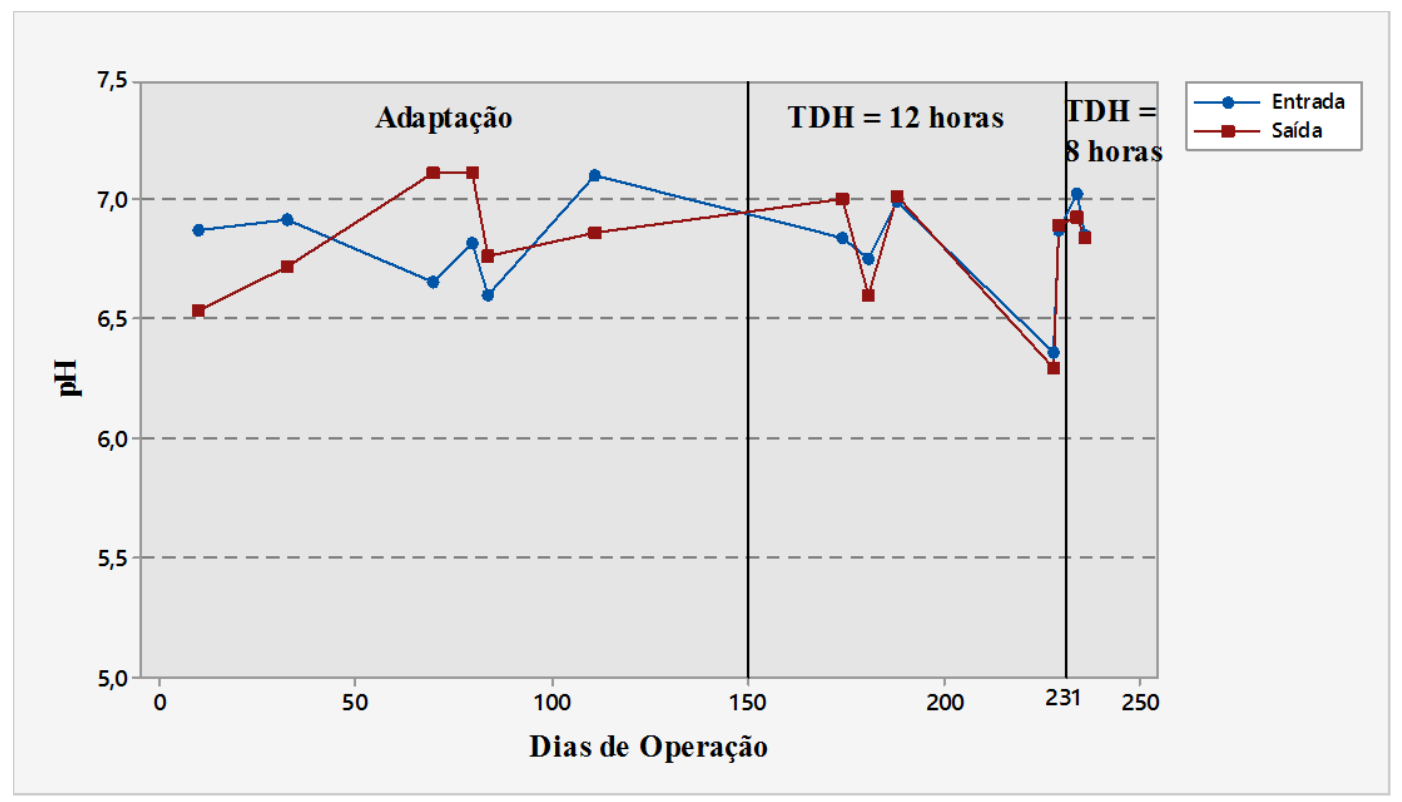

Figura 5.27: Variação do pH de entrada e saída no sistema.

\subsubsection{Alcalinidade}

A presença de alcalinidade em sistemas biológicos é muito importante para impedir o desequilíbrio das reações, em caso de distúrbios do $\mathrm{pH}$ no afluente. Em alguns sistemas 
anaeróbios são observados produção de alcalinidade devido à formação de sais de ácidos voláteis (PIVELI e KATO, 2005).

Observando os valores de alcalinidade total de entrada e saída do sistema (Figura 5.28), nota-se que ocorreu produção de alcalinidade no sistema, o que explica os valores de $\mathrm{pH}$ de saída superiores aos valores de pH de entrada (Figura 5.27).

A alcalinidade total é a soma de duas parcelas: i) alcalinidade intermediária (AI), que se refere à alcalinidade a ácidos orgânicos voláteis; ii) alcalinidade parcial (AP), que se refere à alcalinidade aos bicarbonatos. A relação entre alcalinidade intermediária e alcalinidade parcial é mais um indicador do equilíbrio nos processos anaeróbios, sendo que razões acima de 0,3 podem indicar acúmulo de ácidos orgânicos voláteis, e instabilidade dos sistemas (CHERNICHARO, 2007).

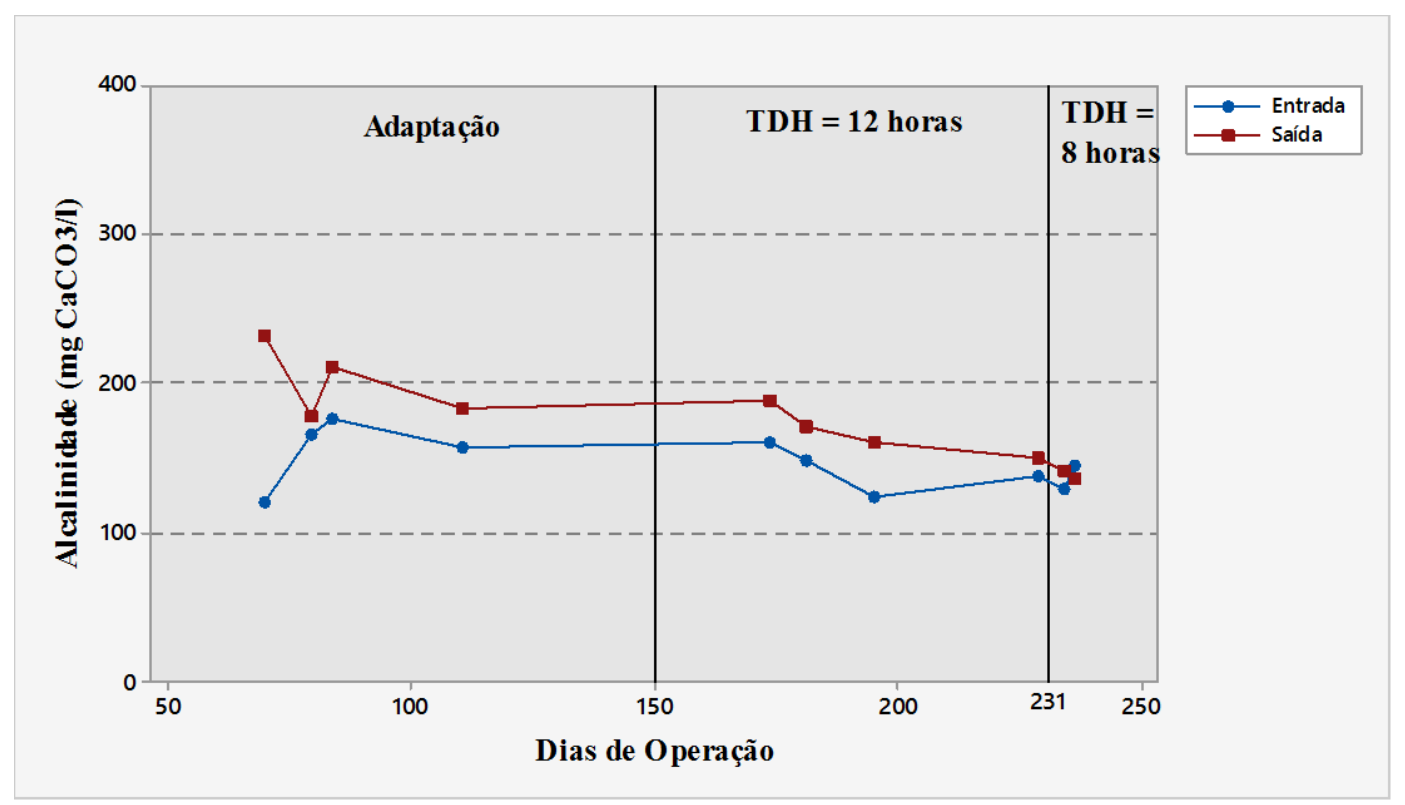

Figura 5.28: Valores de alcalinidade total na entrada e saída do sistema.

Os dados levantados no sistema, indicados na Figura 5.29, mostram valores elevados para essa relação AI/AP, principalmente no esgoto afluente. Mas não foram observadas anomalias na estabilidade do sistema. 


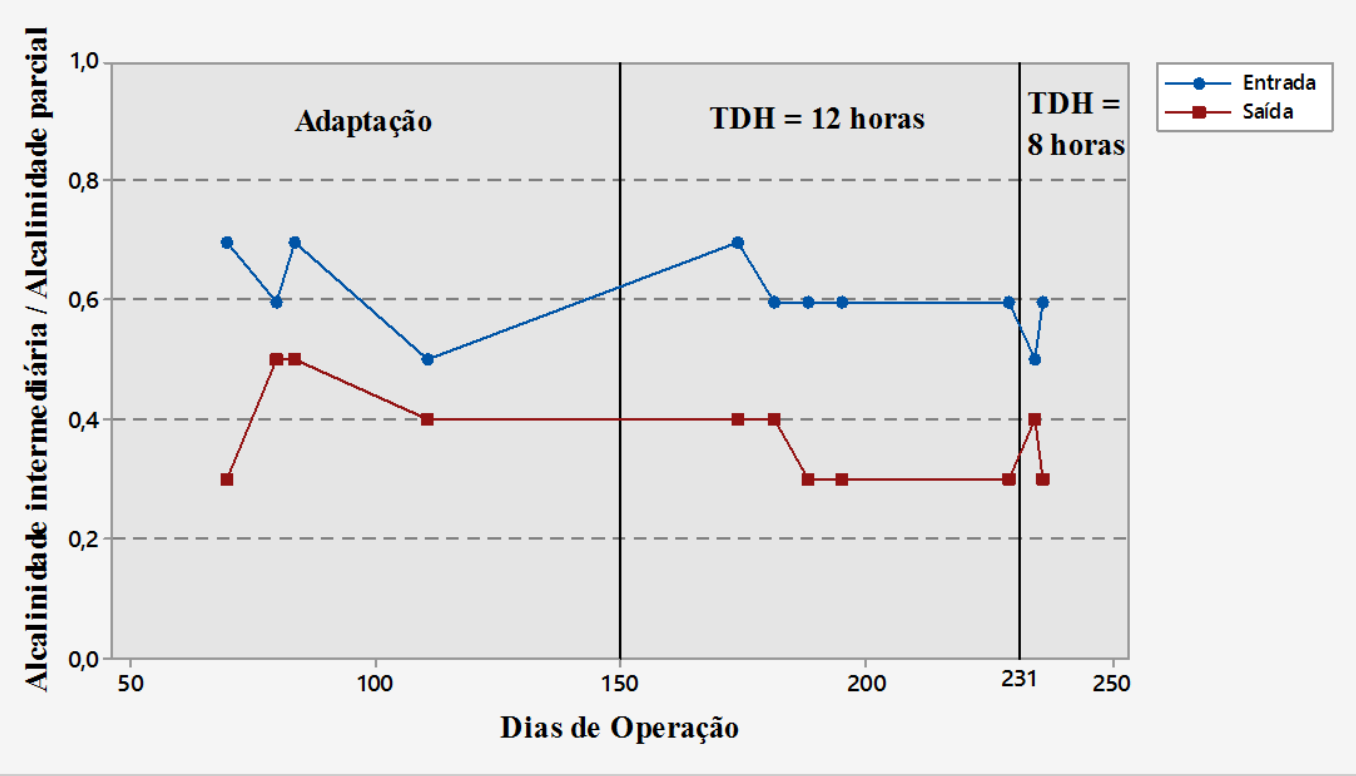

Figura 5.29: Relação entre AI e AP nas amostras de entrada e saída do sistema.

De acordo com Switzembaum et al (1990), outra relação que pode ser usada na determinação da estabilidade do reator é a relação AGV/Alcalinidade. Nos reatores estáveis essa relação deve ser menor que 1 e o indicado é que fique entre 0,1 e 0,35. Na Figura 5.30 estão expostos os valores desta relação, que esteve abaixo de 0,35 para todos pontos.

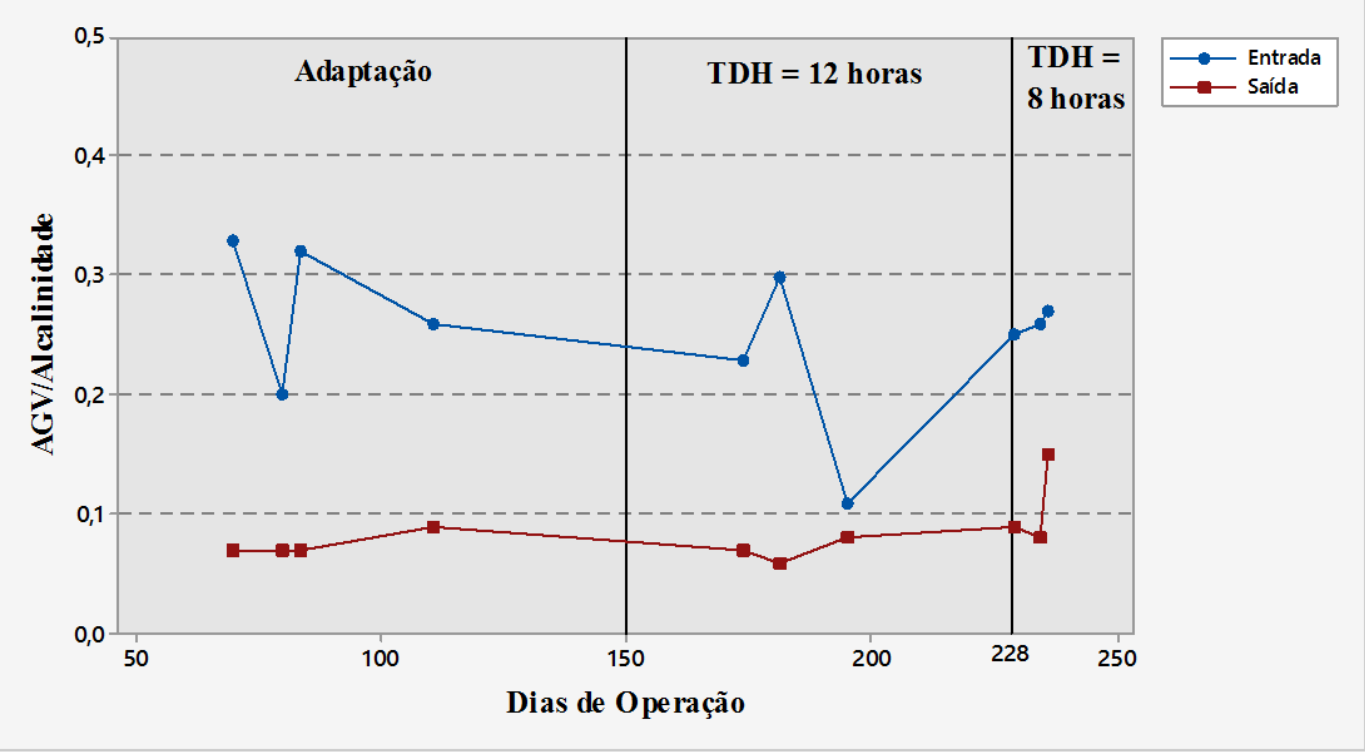

Figura 5.30: Relação AGV/Alcalinidade no sistema piloto. 
Na Tabela 5.10 é apresentado o resumo com os valores médios de entrada, saída e remoção obtidos para cada variável na etapa de operação do sistema com TDH igual a 12 horas.

Destaca-se que a relação DQO/Sulfeto foi superior a 10, o que é vantajoso do ponto de vista de problemas com odores. Além disso, essa relação alta impede a ocorrência exacerbada de processos sulfetogênicos, os quais podem ser responsáveis pela inibição na produção de metano.

Em suma, as eficiências de remoção foram satisfatórias para todos parâmetros medidos (a remoção de nutrientes não era esperada no sistema anaeróbio), e os indicadores de estabilidade comprovaram o equilíbrio do sistema.

Tabela 5.10: Resumo dos valores médios das variáveis de monitoramento obtidas com o sistema operando com $\mathrm{TDH}=12$ horas.

\begin{tabular}{|c|c|c|c|c|}
\hline Variável & $\begin{array}{c}\mathrm{N}^{\circ} \text { de } \\
\text { amostras }\end{array}$ & Entrada & Saída & Remoção (\%) \\
\hline DQO $\left(\mathrm{mg.l}^{-\mathbf{1}}\right)$ & 5 & 332 & 153 & 52,79 \\
\hline DQO filtrada $\left(\mathrm{mg.l}^{-1}\right)$ & 6 & 149 & 48 & 67,09 \\
\hline DBO (mg.l-1 $)$ & 5 & 209 & 60 & 70,90 \\
\hline SST (mg.l $\mathbf{l}^{-1}$ ) & 6 & 115 & 59 & 47,00 \\
\hline NTK (mg.l $\mathbf{l}^{-1}$ ) & 1 & 34 & 31 & 8,82 \\
\hline N.NH4 $\left(\mathrm{mg.l}^{-1}\right)$ & 1 & 27 & 27 & 0 \\
\hline $\mathrm{PO}_{4}^{3-}\left(\mathrm{mg.l}^{-1}\right)$ & 1 & 12,6 & 11,6 & 7,93 \\
\hline $\mathrm{S}^{2-}\left(\mathrm{mg.l}^{-1}\right)$ & 1 & 0,65 & 0,37 & 43,07 \\
\hline pH & 5 & 6,77 & 6,77 & - \\
\hline $\operatorname{AGV}\left(\mathbf{m g . l}^{-1}\right)$ & 4 & 32,50 & 12,75 & - \\
\hline $\begin{array}{c}\text { Alcalinidade } \\
\left(\mathrm{mgCaCO}_{3 . l^{-1}}\right)\end{array}$ & 4 & 142,50 & 167,75 & - \\
\hline
\end{tabular}




\subsubsection{Comportamento da manta de lodo}

Nos reatores biológicos de manta de lodo é de grande importância a identificação do perfil de sólidos em vários pontos ao longo da altura do reator, pois a remoção de compostos degradáveis está diretamente ligada à quantidade e qualidade de biomassa acumulada no reator anaeróbio.

Em decorrência da agitação aplicada, o perfil de sólidos ao longo do reator foi monitorado continuamente para avaliar as respostas da biomassa às diferentes condições operacionais.

O perfil de sólidos foi fator de decisão para determinar o limiar entre os períodos de ajustes iniciais e de operação contínua (etapa sem acréscimos de inóculo no reator) do sistema. O objetivo foi cessar as reinoculações no momento em que o reator estivesse apto a manter concentrações de SST em torno de $5.000 \mathrm{mg}^{-1} \mathrm{l}^{-1}$ a 2,0 m do fundo do reator (ponto de amostragem P1). Lembrando que as amostras, para cada perfil traçado, foram coletadas nos pontos de amostragem P0, P1, P2, P3 e T, e referem-se às alturas 0,0 m; 2,0 m; 3,4 m; 4,2 m e $5,2 \mathrm{~m}$, respectivamente).

Na Figura 5.31 é apresentado o perfil de sólidos suspensos totais imediatamente após a inoculação do reator. Posteriormente à inoculação, o sistema foi mantido sem alimentação por sete dias visando obter adensamento da biomassa. Na Figura 5.32 são expostos os resultados do perfil de sólidos suspensos referentes ao sexto dia após a inoculação.

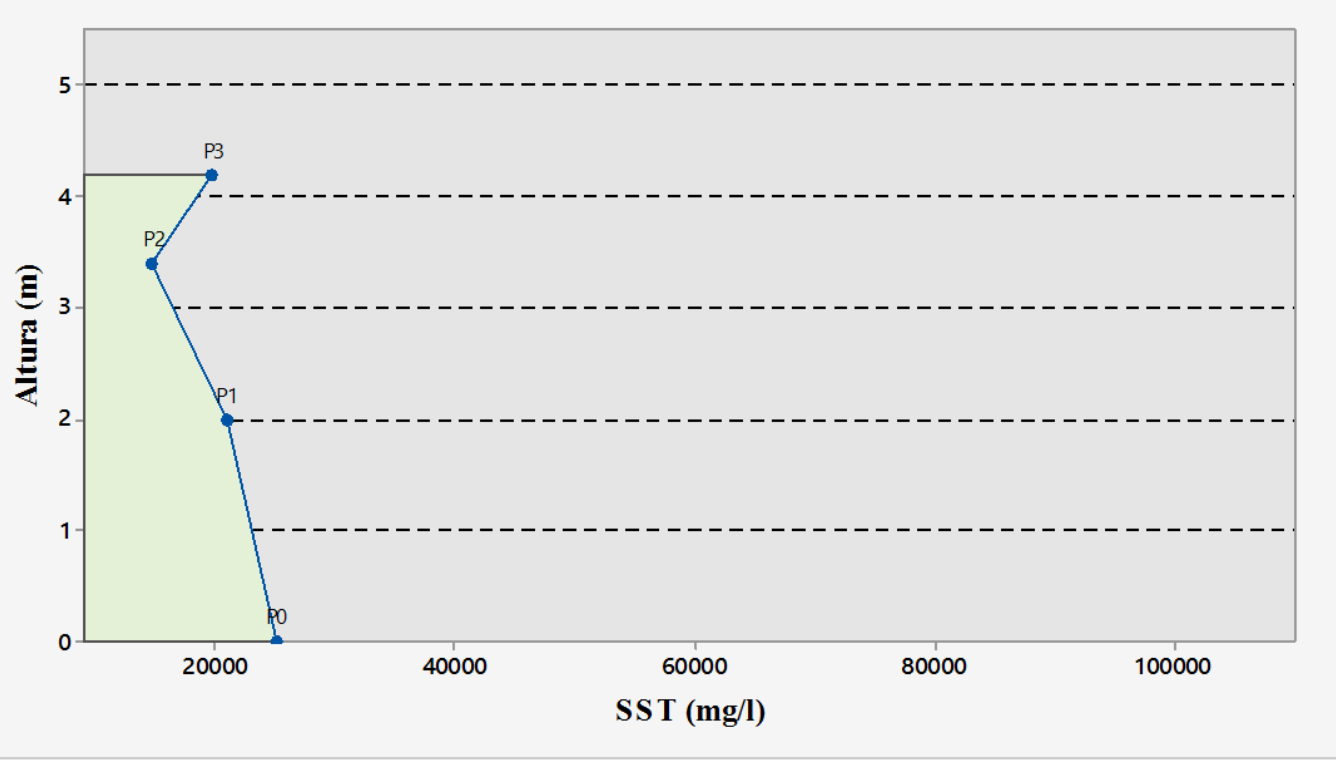

SST (mg.l $\left.\mathbf{l}^{-1}\right)$

$\mathrm{P} 0=25.206$

$\mathrm{P} 1=21.077$

$\mathrm{P} 2=14.890$

$\mathrm{P} 3=19.865$

TEMP.

$17,1^{\circ} \mathrm{C}$

Figura 5.31: Perfil de sólidos suspensos no reator com 0 dias de operação, após inoculação. 


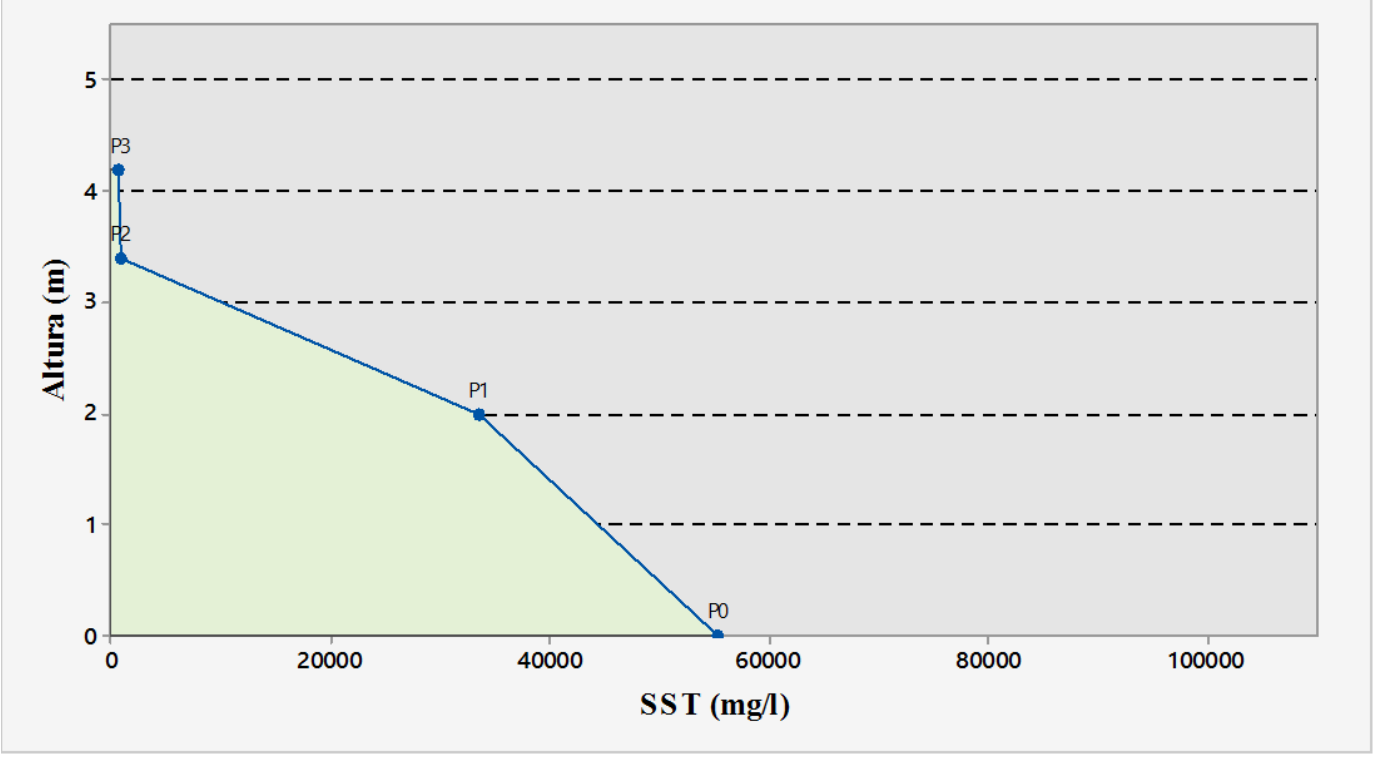

$\operatorname{SST}\left(\mathbf{m g . l}^{-1}\right)$

$\mathrm{P} 0=55.237$

$\mathrm{P} 1=33.630$

$\mathrm{P} 2=848$

$\mathrm{P} 3=810$

TEMP.

$21,3{ }^{\circ} \mathrm{C}$

Figura 5.32: Perfil de sólidos suspensos no reator 6 dias após a inoculação, sem alimentação.

Note-se que ocorreu um adensamento até cerca de 3\% do lodo do fundo nesse período, e que a manta de lodo estava com concentrações de sólidos satisfatórias no ponto de amostragem de $2,0 \mathrm{~m}$.

A partir do oitavo dia após a inoculação, o sistema passou a ser alimentado com o esgoto sanitário proveniente do Campus 1 da USP/São Carlos. Essa alimentação foi da ordem de 1,387 $\mathrm{m}^{3} \cdot \mathrm{h}^{-1}(\mathrm{TDH}$ médio $=15$ horas $)$. Foi adotado alto tempo de detenção hidráulico médio para evitar arraste da biomassa junto ao efluente do sistema. Na Figura 5.33 é mostrado o perfil de sólidos suspensos no terceiro dia de operação com o sistema sendo alimentado. No gráfico é possível observar que a manta de lodo expandiu-se, atingindo alta concentração de sólidos em P2. 


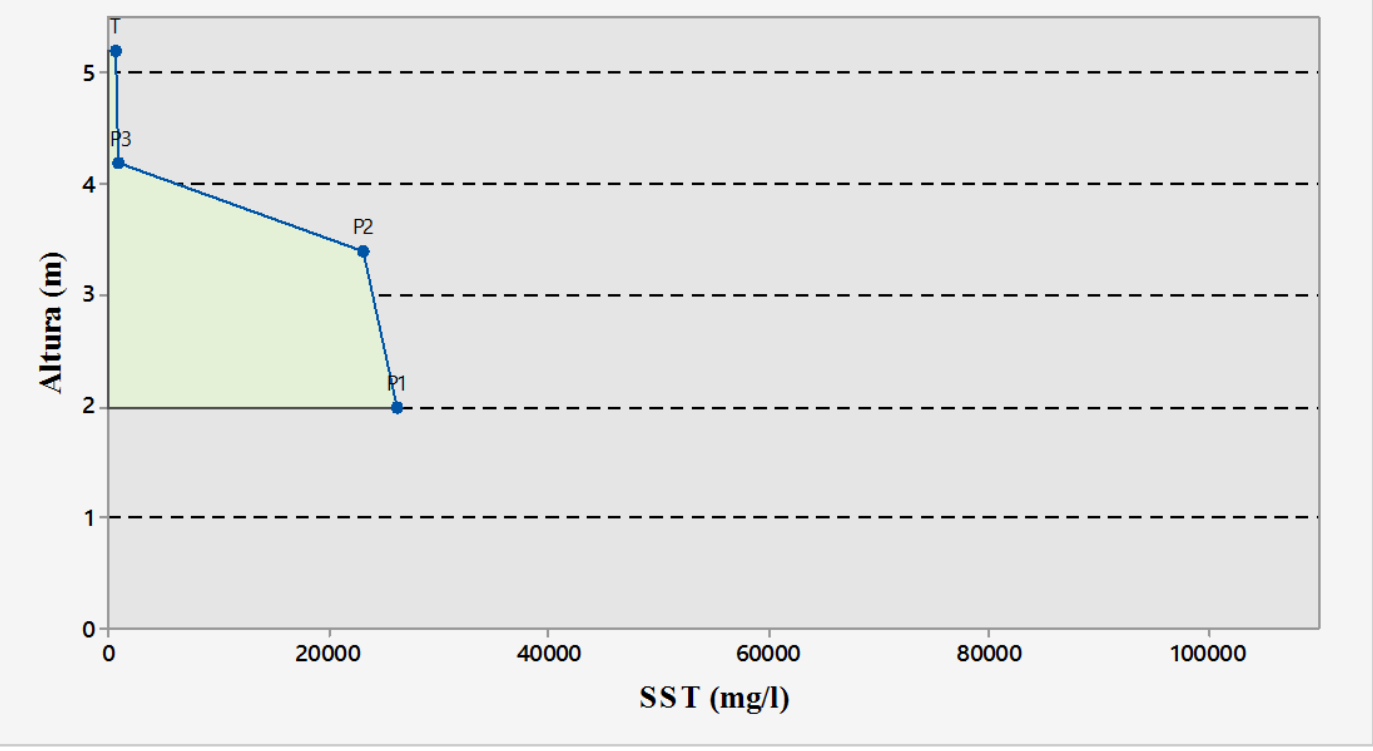

SST (mg.l-1)

$\mathrm{P} 1=26.280$

$\mathrm{P} 2=23.067$

$\mathrm{P} 3=1.010$

$\mathrm{T}=657$

TEMP.

$21,1^{\circ} \mathrm{C}$

Figura 5.33: Perfil de sólidos suspenso no reator com 10 dias de operação, após a inoculação.

$\mathrm{Na}$ terceira semana de operação do sistema, foi levantado novo perfil de sólidos, mediante o qual pode-se constatar que a concentração de SST no fundo do reator continuava satisfatória. No entanto, a concentração dos sólidos da manta de lodo nos pontos 1 e 2 diminuiu como pode ser observado na Figura 5.34, apontando arraste de sólidos com o efluente. Dessa forma optou-se por adicionar mais $10 \mathrm{~m}^{3}$ de lodo anaeróbio (reinoculação) e foi colocado em funcionamento o sistema de retorno de lodo: $0,2 \mathrm{~m}^{3}$ de lodo era bombeado diariamente (por bomba centrífuga de rotor aberto) do fundo do decantador para o sistema de alimentação do reator.

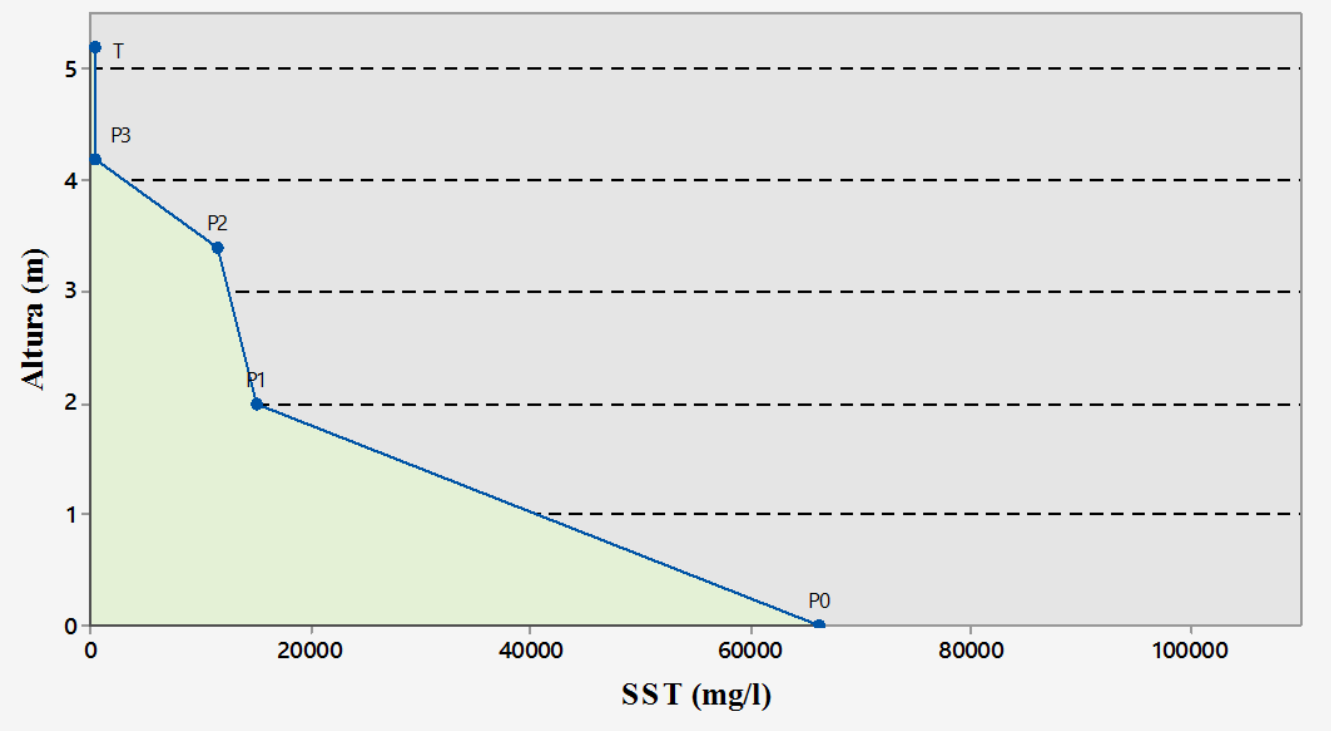

$\operatorname{SST}\left(\mathbf{m g . l}^{-1}\right)$

$\mathrm{P} 0=66.303$

$\mathrm{P} 1=15.043$

$\mathrm{P} 2=11.637$

$\mathrm{P} 3=517$

$\mathrm{T}=405$

TEMP.

$19,3{ }^{\circ} \mathrm{C}$

Figura 5.34: Perfil de sólidos suspensos no reator com 33 dias de operação, após a inoculação. 
Após 45 dias de operação e com o sistema de retorno de lodo em funcionamento, a vazão de alimentação do sistema foi elevada para $1,733 \mathrm{~m}^{3} \cdot \mathrm{h}^{-1}(\mathrm{TDH}$ médio $=12$ horas $)$.

A Figura 5.35 exibe o perfil de sólidos no terceiro dia após a adoção dos novos parâmetros operacionais. Apesar das mudanças, o perfil de SST do reator pouco diferiu em relação ao perfil anterior.

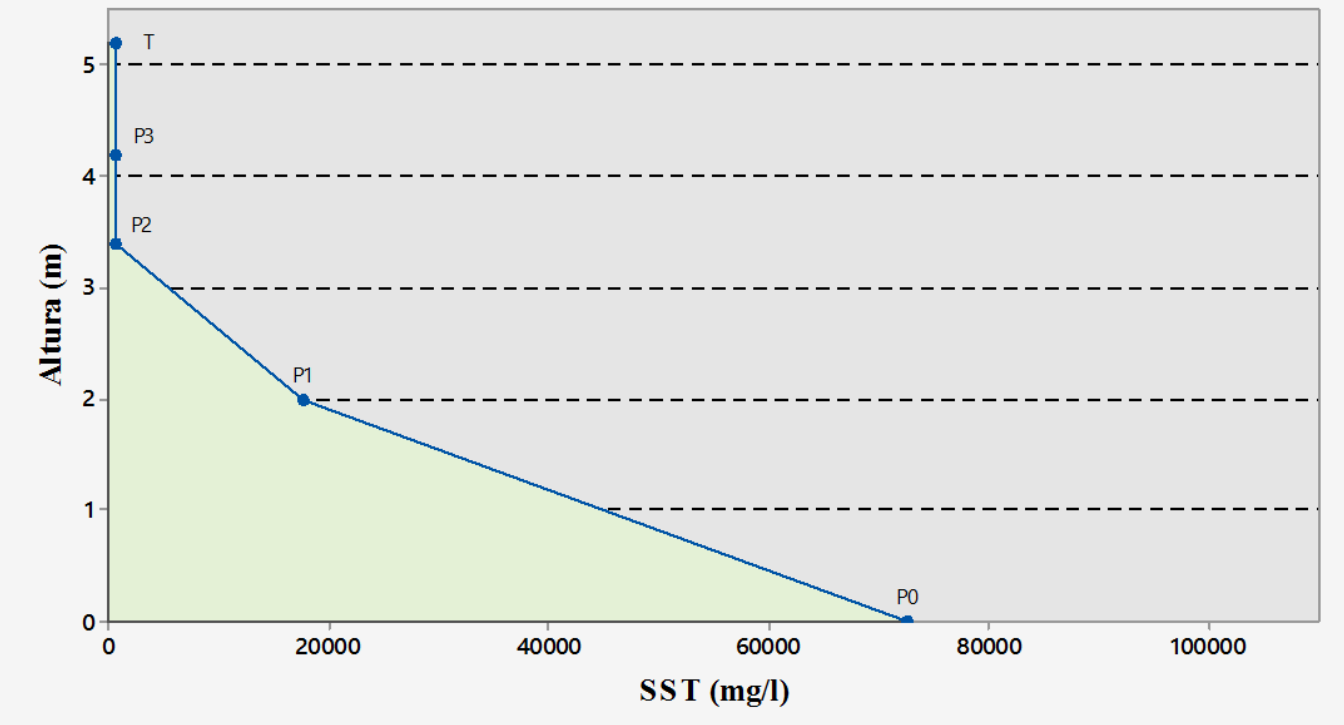

SST (mg.l-1)

$\mathrm{P} 0=72.590$

$\mathrm{P} 1=17.690$

$\mathrm{P} 2=677$

$\mathrm{P} 3=670$

$\mathrm{T}=683$

TEMP.

$19,3{ }^{\circ} \mathrm{C}$

Figura 5.35: Perfil de sólidos suspensos no reator com 03 dias de operação, após o $2^{\circ}$ inóculo.

Com 19 dias de operação desde a segunda inoculação, a concentração de sólidos em P1 manteve-se elevada. Esse dado motivou o aumento da vazão aplicada no sistema para o valor de $2,08 \mathrm{~m}^{3} \cdot \mathrm{h}^{-1}(\mathrm{TDH}$ médio $=10$ horas $)$.

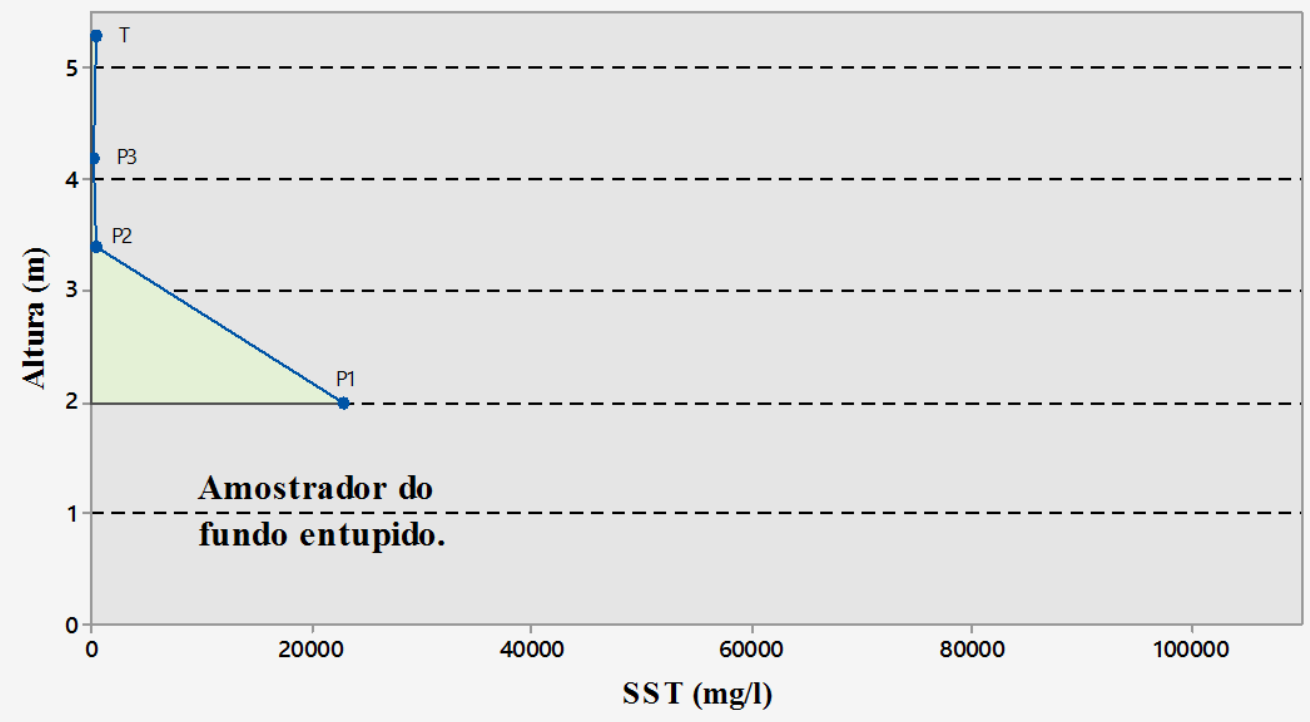

SST (mg.l-1)

$\mathrm{P} 1=23.012$

$\mathrm{P} 2=464$

$\mathrm{P} 3=340$

$\mathrm{T}=437$

TEMP.

$18,3^{\circ} \mathrm{C}$

Figura 5.36: Perfil de sólidos suspensos no reator com 19 dias após a segunda inoculação. 
Devido à tentativa de se operar o sistema com maior vazão de entrada, em dez dias ocorreu grande arraste de lodo do sistema, e, como ilustrado na Figura 5.37, a partir de 2,0 m não havia mais presença da manta de lodo.

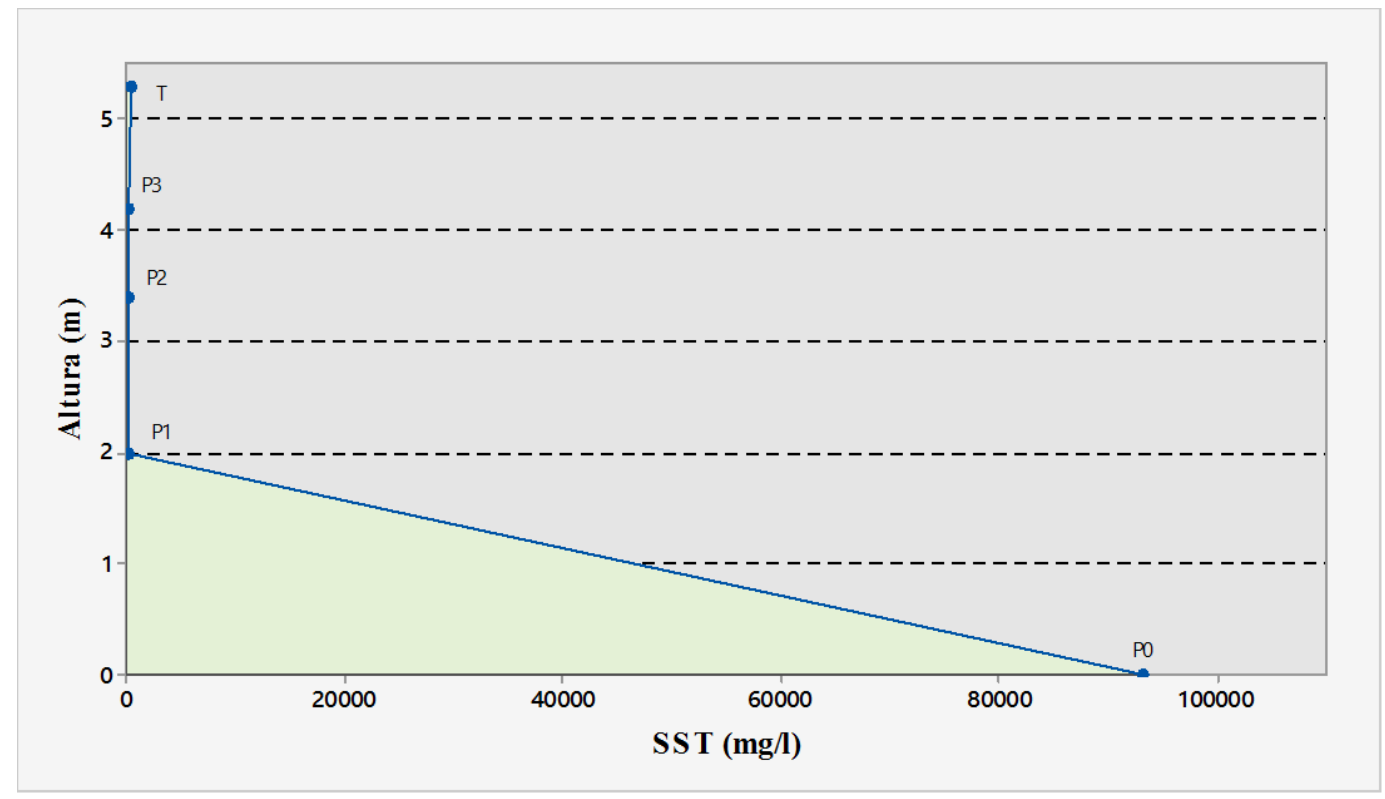

$\operatorname{SST}\left(\mathbf{m g} \cdot \mathbf{l}^{-1}\right)$

$\mathrm{P} 0=93.290$

$\mathrm{P} 1=263$

$\mathrm{P} 2=207$

$\mathrm{P} 3=243$

$\mathrm{T}=567$

TEMP.

$20,3{ }^{\circ} \mathrm{C}$

Figura 5.37: Perfil de sólidos suspensos no reator 29 dias após o segundo inóculo.

Em virtude do carreamento de lodo, mostrado na Figura 5.37, procedeu-se na adição de inóculo ao reator no $85^{\circ}$ dia de operação do sistema. Após essa inoculação o sistema continuou a ser operado com $\mathrm{TDH}$ médio $=10$ horas.

A Figura 5.38 apresenta o perfil de sólidos no reator 26 dias após o terceiro inóculo (111 dias de operação total). Nota-se que, apesar do aumento na concentração de sólidos no fundo do reator, a 2,0m de altura não havia presença de lodo. 


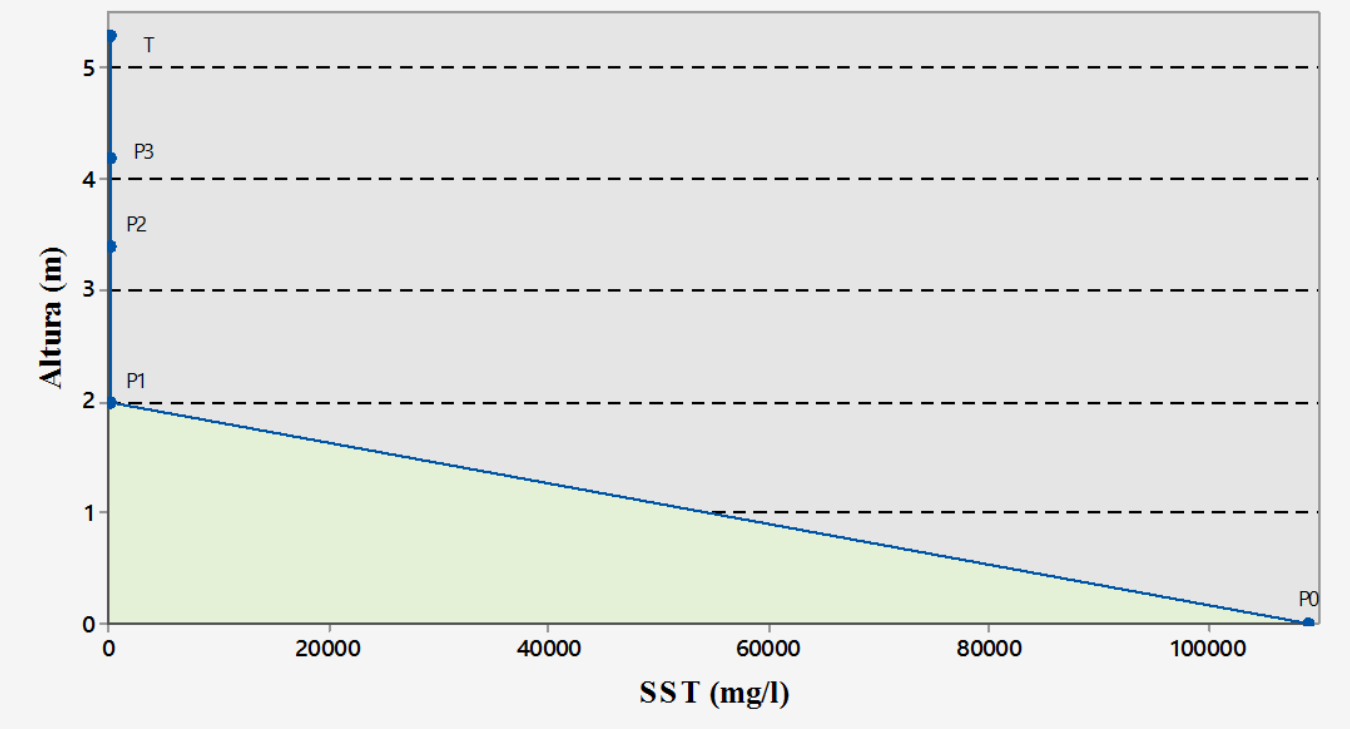

$\operatorname{SST}\left(\mathbf{m g . l}^{-1}\right)$

$\mathrm{P} 0=109.156$

$\mathrm{P} 1=126$

$\mathrm{P} 2=146$

$\mathrm{P} 3=132$

$\mathrm{T}=193$

TEMP.

$24,2{ }^{\circ} \mathrm{C}$

Figura 5.38: Perfil de sólidos suspensos no reator 26 dias após o terceiro inóculo.

A partir desse momento da operação observou-se que mudanças deveriam ser executadas no modo operacional do sistema, pois a manutenção da manta de lodo a dois metros de altura estava sendo difícil de ser alcançada.

Dessa forma, adicionou-se novo inóculo no $113^{\circ}$ dia de operação, e a primeira estratégia adotada foi a alteração da vazão de alimentação do sistema, estabelecendo novamente TDH médio de 15 horas, para melhor adaptação do lodo ao afluente.

O sistema foi operado 30 dias nestas condições e, após esse período, foi constatado que a 2,0 m não havia lodo novamente.

Dessa forma, com 150 dias de operação o reator recebeu outra inoculação e foi instalado novo sistema de recirculação de lodo do decantador para o reator. A partir deste instante deuse início à etapa de operação contínua do sistema, onde foi adotado TDH médio de 12 horas. Nesse novo sistema de recirculação o bombeamento foi realizado por bomba helicoidal e o volume de lodo retornado diariamente foi elevado para 600 litros. Apesar de toda massa de lodo ser recirculada em torno de dez minutos (na maioria dos dias), optou-se por promover recirculação diária de 15 minutos para atender os picos de arraste de lodo que ocorriam ocasionalmente. Na Figura 5.39 é mostrada a concentração de sólidos coletada na linha de recirculação de lodo. Nota-se que a concentração de sólidos é muito elevada, em alguns momentos acima das concentrações encontradas na manta de lodo. 


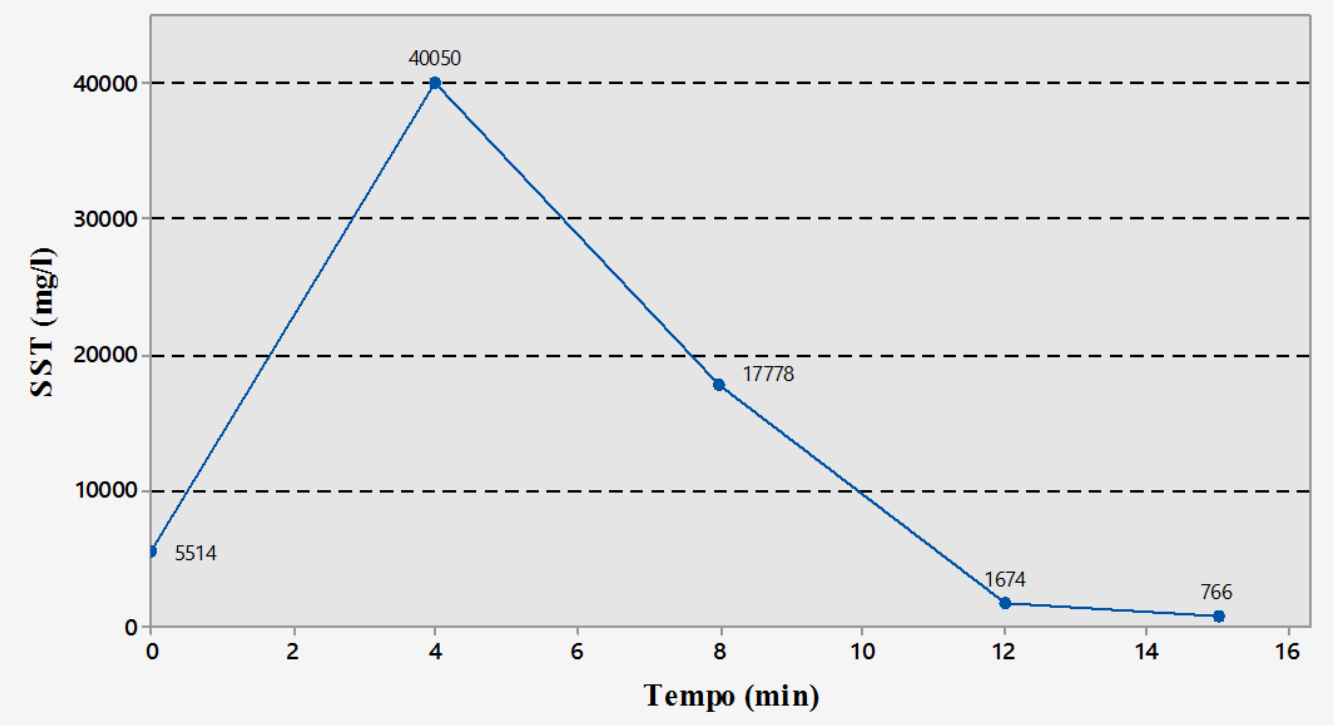

Figura 5.39: Concentração de sólidos no lodo recirculado do decantador para o reator.

Após 26 dias do último inóculo, com o novo sistema de recirculação operando diariamente, a manta de lodo manteve-se expandida até 3,4 m (P2), como pode ser observado no perfil de sólidos da Figura 5.40.

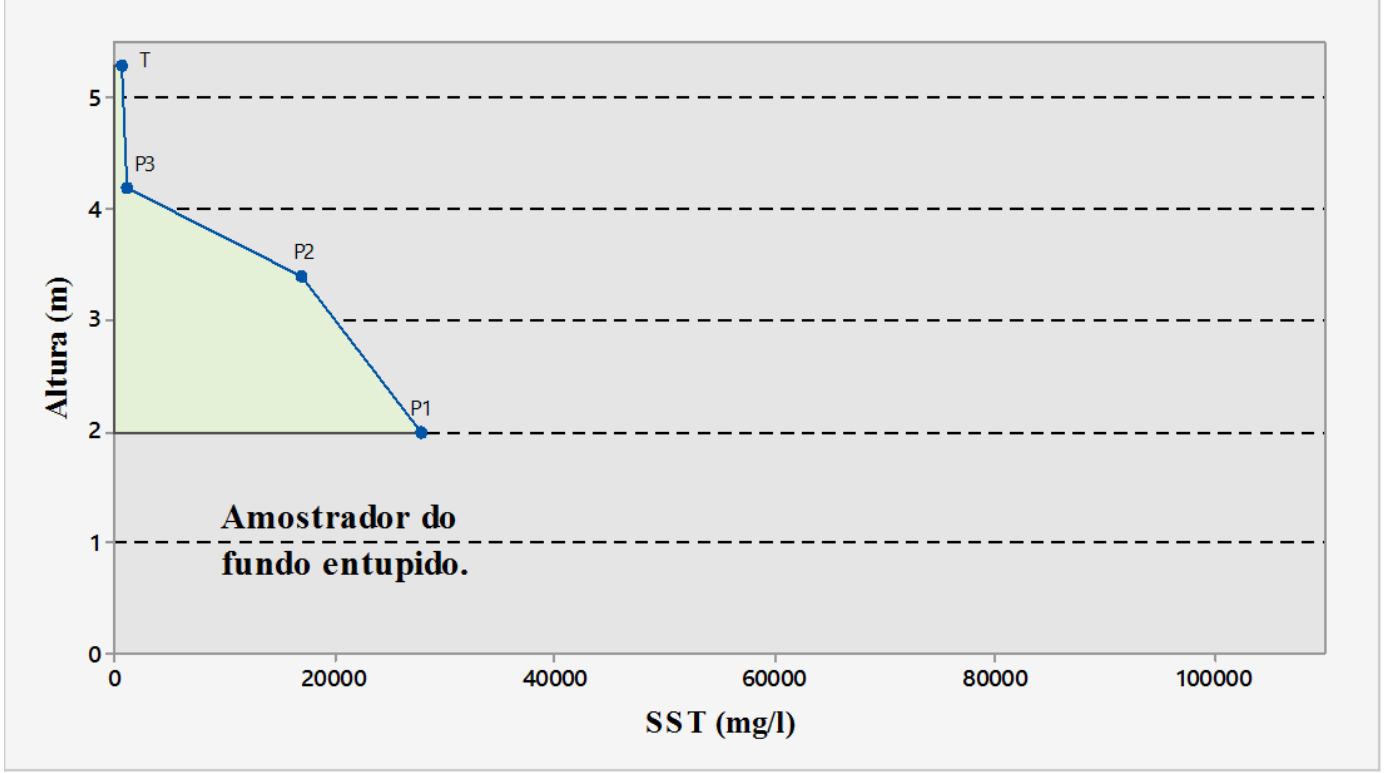

$\operatorname{SST}\left(\mathbf{m g . l}^{-1}\right)$

$\mathrm{P} 1=27.926$

$\mathrm{P} 2=17.110$

$\mathrm{P} 3=1224$

$\mathrm{T}=630$

TEMP.

$24,4{ }^{\circ} \mathrm{C}$

Figura 5.40: Perfil de sólidos suspensos 26 dias após a última inoculação.

A Figura 5.41 mostra o perfil de sólidos com 33 dias de operação contínua do sistema, após a adição do quinto inóculo. Nota-se que o perfil de sólidos suspensos pouco variou em 
relação ao perfil anterior. Na Figura 5.42 é apresentado o perfil de sólidos suspensos 40 dias após a última inoculação do sistema, apresentando mais uma vez estabilidade na manutenção da manta de lodo.

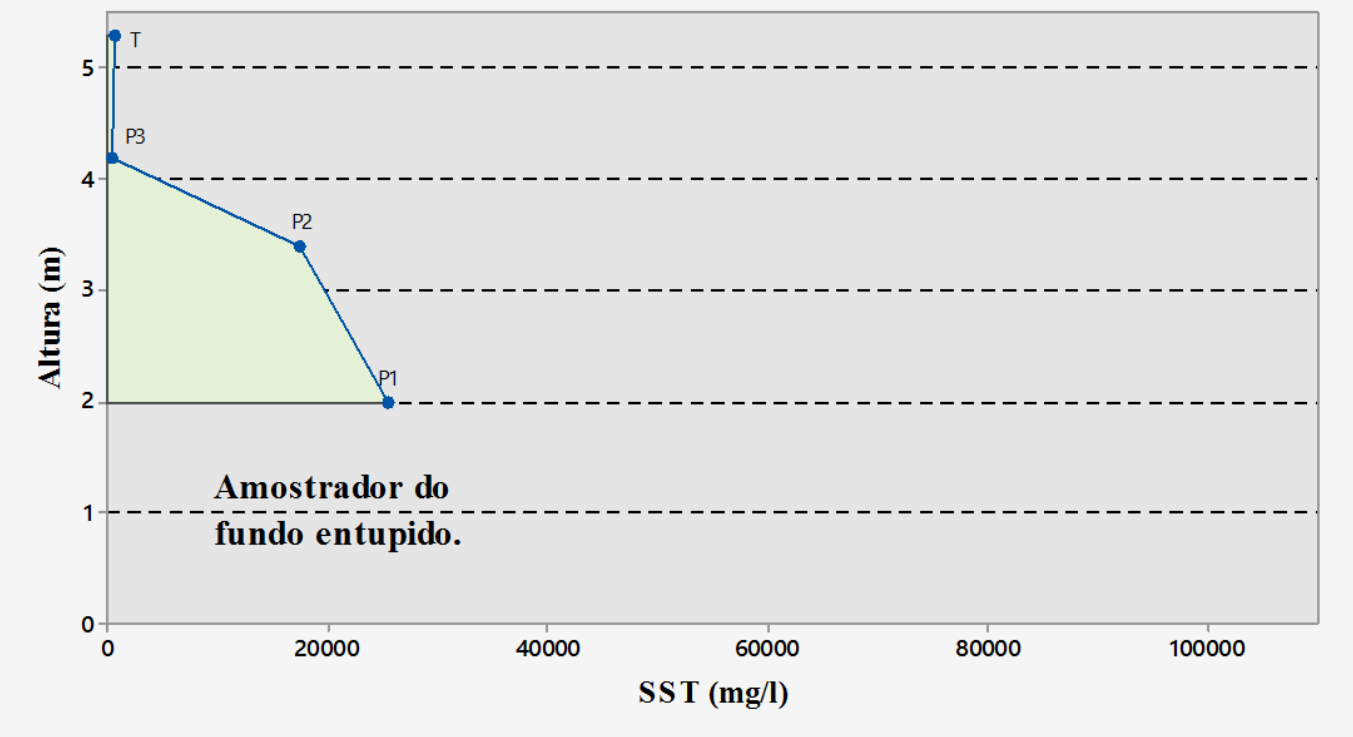

SST (mg. $\mathbf{l}^{-1}$ )

$\mathrm{P} 1=25.496$

$\mathrm{P} 2=17.596$

$\mathrm{P} 3=528$

$\mathrm{T}=755$

TEMP.

$23,4{ }^{\circ} \mathrm{C}$

Figura 5.41:Perfil de sólidos suspensos 33 dias após o quinto inóculo.

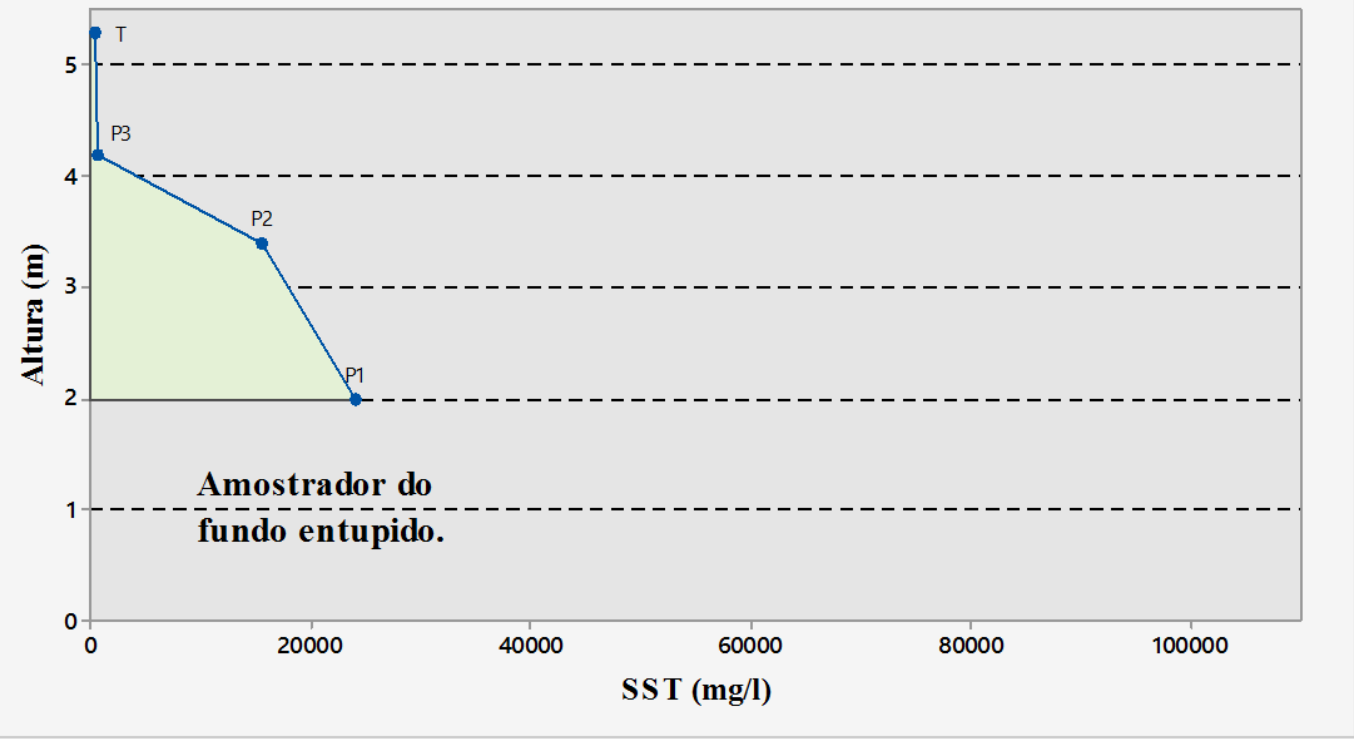

SST (mg.l $\left.\mathbf{l}^{-1}\right)$

$\mathrm{P} 1=24.050$

$\mathrm{P} 2=15.602$

$\mathrm{P} 3=640$

$\mathrm{T}=535$

TEMP.

$22,6^{\circ} \mathrm{C}$

Figura 5.42: Perfil de sólidos suspensos 40 dias após o último inóculo. 
Após a manta permanecer estável até 3,4 m de altura por mais de um mês, no período do $40^{\circ}$ ao $80^{\circ}$ dia da segunda etapa foi testada a alteração na rotina de recirculação do lodo, que passou a ser executada a cada dois dias. O resultado é apresentado no perfil da Figura 5.43, e mostra que a manta voltou a ficar abaixo dos 2,0 $\mathrm{m}$ de altura.

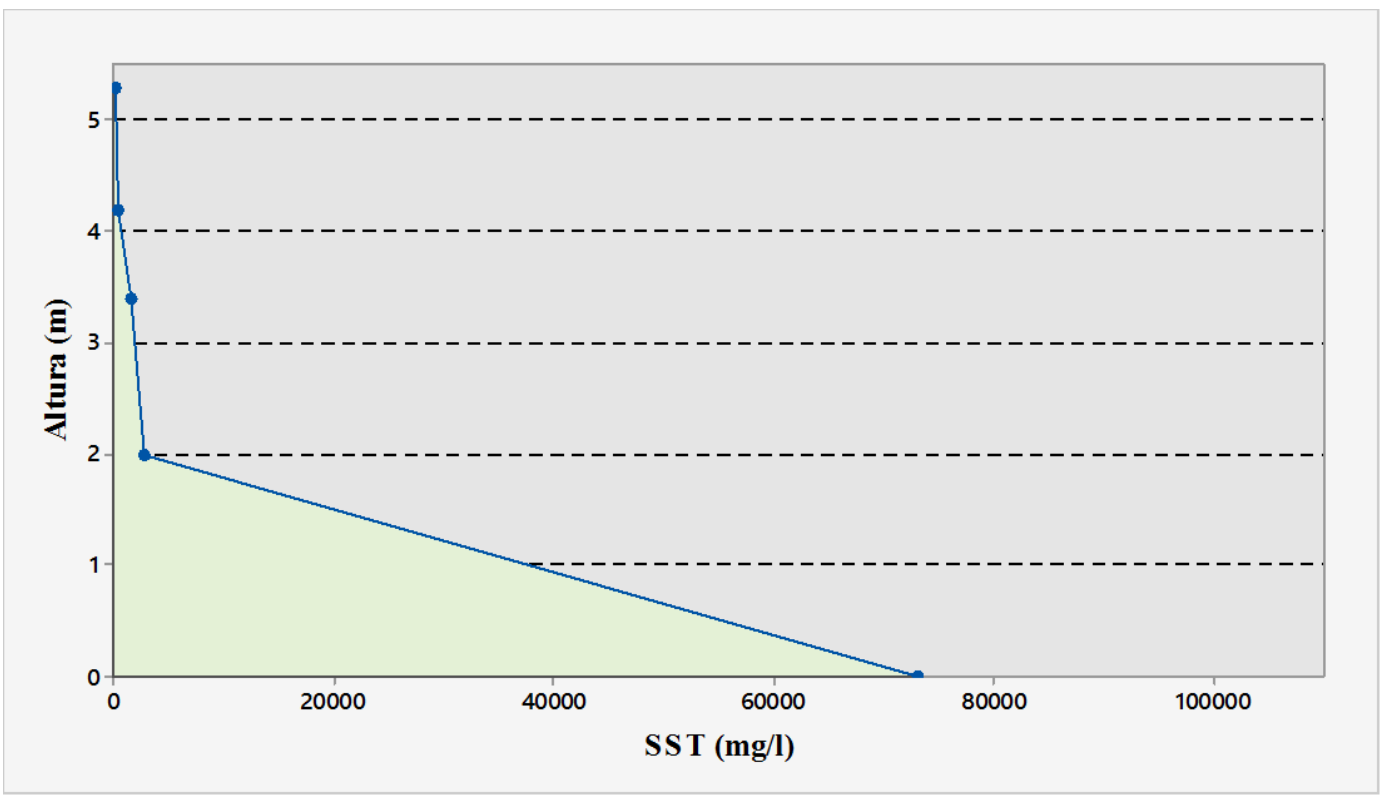

\section{SST (mg. -1 $\left.^{-1}\right)$}

$\mathrm{P} 0=73.080$

$\mathrm{P} 1=2.924$

$\mathrm{P} 2=1.752$

$\mathrm{P} 3=396$

$\mathrm{T}=228$

TEMP.

$25,7^{\circ} \mathrm{C}$

Figura 5.43: Perfil de sólidos 81 dias após o início da segunda etapa de operação (228 dias de operação total).

Com intuito de avaliar o processo de tratamento de esgotos ao longo da altura do reator foram coletadas amostras ao longo do "percurso" do efluente. As amostras foram coletadas na entrada do sistema, nos quatro pontos de amostragem de lodo, e na saída do sistema. A Tabela 5.11 apresenta os resultados do ensaio. É dada ênfase à remoção de 74,3\% de matéria orgânica somente nos dois primeiros metros do reator. Esse resultado já era esperado devido à baixa expansão da manta de lodo.

Após a "perda" da expansão da manta de lodo mostrada na Figura 5.43, deu-se início à última etapa de operação do sistema, que consistiu em avaliar a resposta do reator ao aumento do TDH médio de entrada. Na Figura 5.44 é apresentado o perfil de sólidos com o reator operando com TDH médio de 8 horas. A concentração de sólidos suspensos aumentou para o ponto de amostragem a 2,0 $\mathrm{m}$ de altura, o que indica que o lodo encontrava-se adensado abaixo $\operatorname{dos} 2,0 \mathrm{~m}$. 
Tabela 5.11: Resultados de DQO filtrada, $\mathrm{S}^{2-}, \mathrm{PO}_{4}{ }^{3-}, \mathrm{pH}$, Alcalinidade e AGV/Alcalinidade para $\mathrm{TDH}=12$ horas e 228 dias de operação.

\begin{tabular}{|c|c|c|c|c|c|c|}
\hline & $\begin{array}{c}\text { DQO filtrada } \\
\left(\mathrm{mg.l}^{-1}\right)\end{array}$ & $\begin{array}{c}\mathrm{S}^{2-} \\
\left(\mathrm{mg.l^{-1 }}\right)\end{array}$ & $\begin{array}{c}\mathrm{PO}_{4}{ }^{3-} \\
\left(\mathrm{mg.l}^{-1}\right)\end{array}$ & pH & $\begin{array}{c}\text { Alcalinidade } \\
\left(\mathrm{mgCaCO}_{\left.3 . \mathbf{l}^{-1}\right)}\right.\end{array}$ & AGV/Alc \\
\hline Entrada & 214 & 0,062 & 9,5 & 6,37 & 124 & 0,11 \\
\hline P0 & 190 & 0,298 & 8,7 & 6,47 & 232,5 & 0,08 \\
\hline $\mathbf{P 1}$ & 55 & 0,032 & 10,4 & 6,55 & 203,6 & 0,07 \\
\hline $\mathbf{P 2}$ & 48 & 0,044 & 10,1 & 6,46 & 176,4 & 0,08 \\
\hline P3 & 50 & 0,028 & 9,9 & 6,38 & 166,8 & 0,07 \\
\hline Topo & 69 & 0,028 & 9,9 & 6,29 & 160,4 & 0,09 \\
\hline Saída & 57 & 0,024 & 9,0 & 6,30 & 160,4 & 0,08 \\
\hline
\end{tabular}

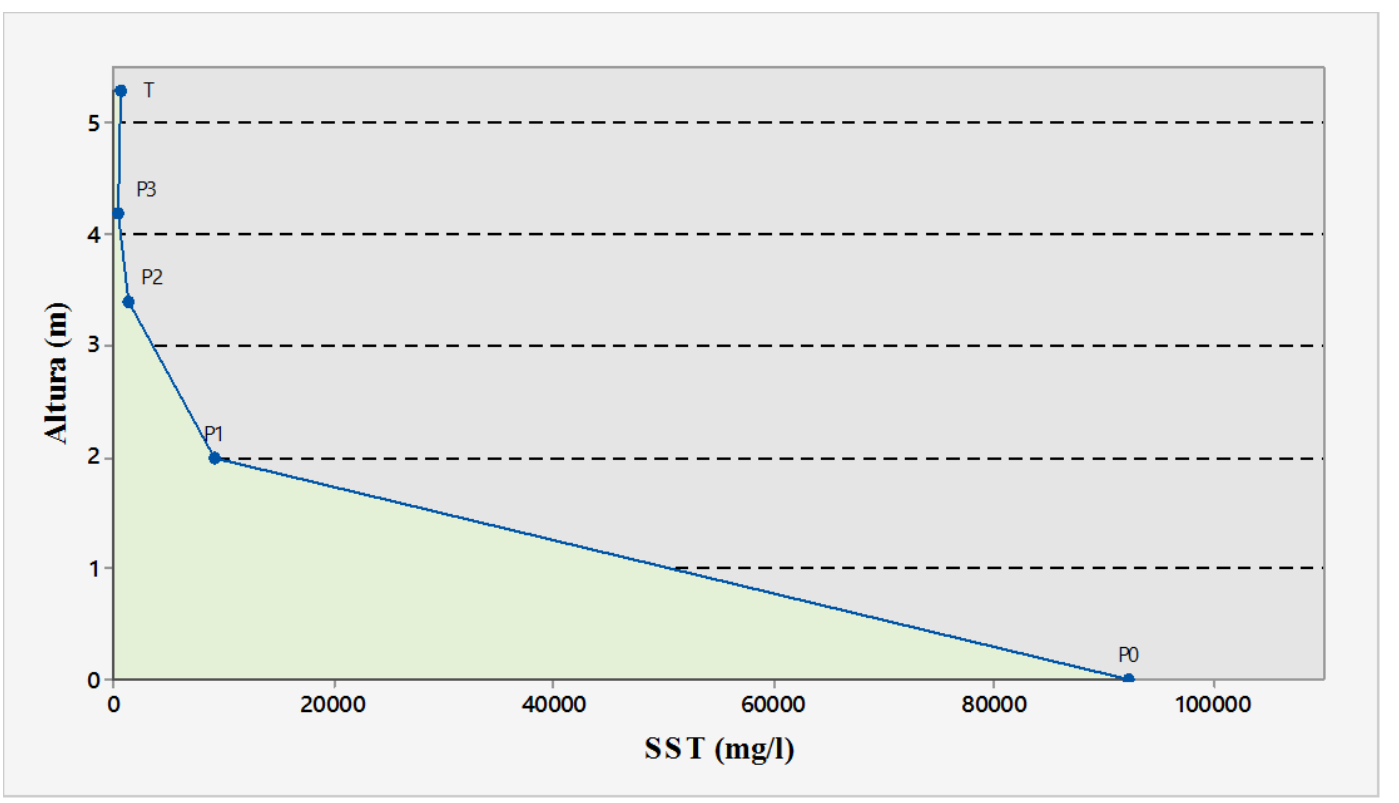

SST (mg.l-1)

$\mathrm{P} 0=92.184$

$\mathrm{P} 1=9.124$

$\mathrm{P} 2=1.426$

$\mathrm{P} 3=507$

$\mathrm{T}=608$

TEMP.

$22,3{ }^{\circ} \mathrm{C}$

Figura 5.44: Perfil de sólidos para sistema operando com TDH de 8 horas.

Para o perfil de sólidos apresentado na Figura 5.44, foi traçado o perfil de tratamento do esgoto sanitário, apresentado na Tabela 5.12. Apesar de a concentração de sólidos suspensos da manta estar elevada, a remoção de matéria orgânica nos dois primeiros metros foi de 73,4\%, percentual quase idêntico ao observado na Tabela 5.11 para o reator operando com TDH de 12 horas. Esse resultado indica que o tratamento do esgoto sanitário estava ocorrendo apenas na porção inferior do reator, independentemente do nível de expansão da manta de lodo. 
Tabela 5.12: Resultados de DQO filtrada, $\mathrm{S}^{2-}, \mathrm{PO}_{4}{ }^{3-}, \mathrm{pH}$, Alcalinidade e AGV/Alcalinidade para $\mathrm{TDH}=8$ horas e 236 dias de operação.

\begin{tabular}{|c|c|c|c|c|c|c|}
\hline & $\begin{array}{l}\text { DQO filtrada } \\
\qquad\left(\mathrm{mg.l}^{-1}\right)\end{array}$ & $\begin{array}{c}\mathrm{S}^{2-} \\
\left(\mathrm{mg.l^{-1 }}\right)\end{array}$ & $\begin{array}{c}\mathrm{PO}_{4}{ }^{3-} \\
\left(\mathrm{mg}^{-} \mathrm{l}^{-}\right. \\
1)\end{array}$ & $\mathbf{p H}$ & $\begin{array}{l}\text { Alcalinidade } \\
\left(\mathrm{mgCaCO}_{3 . \mathrm{I}^{-1}}\right)\end{array}$ & AGV/Alc \\
\hline Entrada & 218 & 0,073 & 7,6 & 6,86 & 144,8 & 0,27 \\
\hline P0 & 309 & 0,876 & 18,0 & 6,61 & 239,3 & 0,09 \\
\hline P1 & 58 & 0,183 & 11,0 & 6,90 & 462,8 & 0,03 \\
\hline P2 & 57 & 0,038 & 6,6 & 6,94 & 148,4 & 0,20 \\
\hline P3 & 47 & 0,044 & 7,4 & 6,73 & 152,4 & 0,08 \\
\hline Topo & 64 & 0,053 & 2,2 & 6,76 & 152,8 & 0,11 \\
\hline Saída & 53 & 0,026 & 7,4 & 6,85 & 136,0 & 0,15 \\
\hline
\end{tabular}

Na Figura 5.45 é apresentado o perfil de sólidos no $13^{\circ}$ dia do reator operando com TDH médio de 8 horas (terceira etapa do experimento). Nota-se que houve grande dispersão do lodo do fundo. Porém essa alteração no perfil de sólidos não teve influência, novamente, sobre a remoção da DQO filtrada.

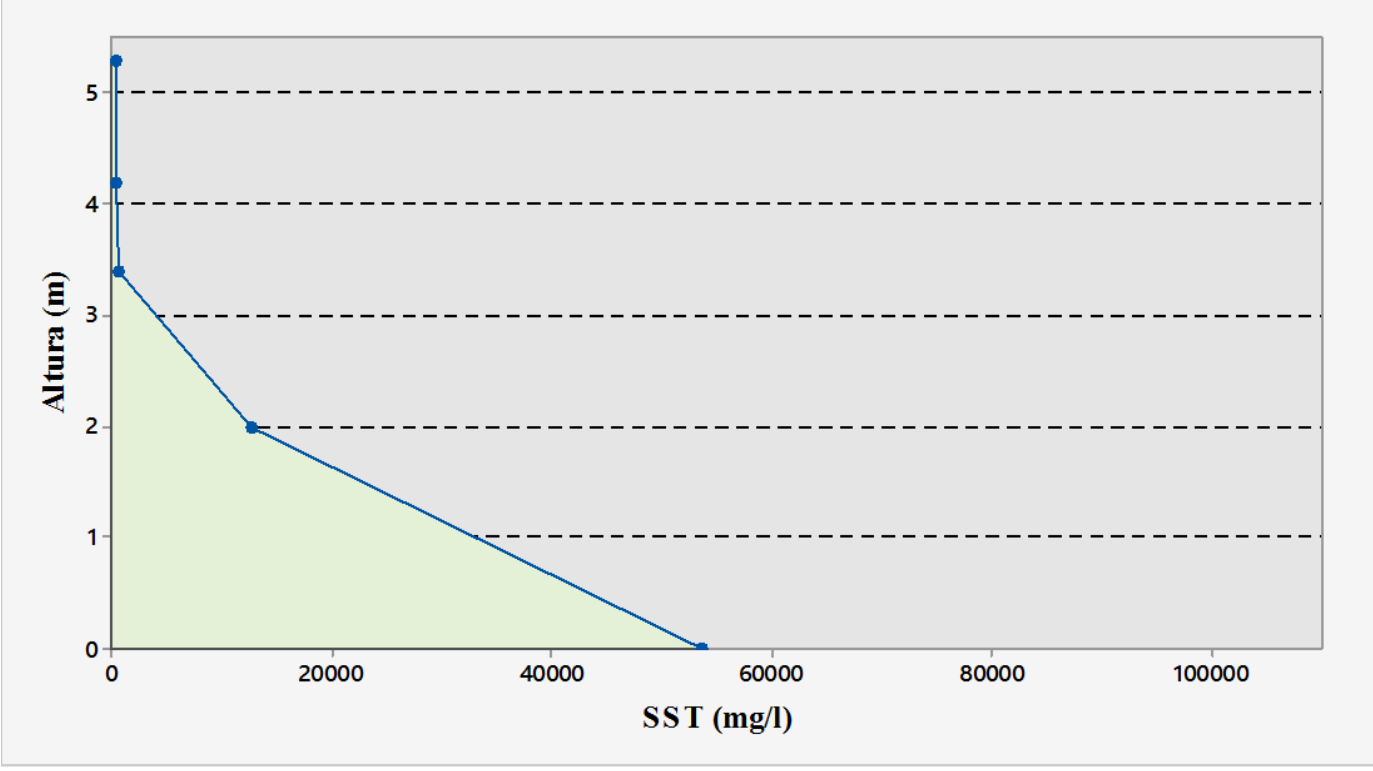

SST $\left(\mathbf{m g .}^{\mathbf{l}^{\mathbf{1}}}\right)$
$\mathrm{P} 0=53.758$
$\mathrm{P} 1=12.870$
$\mathrm{P} 2=824$
$\mathrm{P} 3=470$
$\mathrm{~T}=430$

Figura 5.45: Perfil de sólidos para o $246^{\circ}$ dia de operação do sistema. 
Tabela 5.13: Resultados de DQO filtrada, $\mathrm{S}^{2-}, \mathrm{PO}_{4}{ }^{3-}, \mathrm{pH}$, Alcalinidade e AGV/Alcalinidade para TDH $=8$ horas e 241 dias de operação.

\begin{tabular}{cccc}
\hline & $\begin{array}{c}\text { DQO filtrada } \\
\left(\mathbf{m g . l}^{-\mathbf{1}}\right)\end{array}$ & $\begin{array}{c}\mathbf{S}^{\mathbf{2 -}} \\
\left(\mathbf{m g . \mathbf { l } ^ { - 1 }}\right)\end{array}$ & $\begin{array}{c}\mathbf{P O}_{\mathbf{4}}^{\mathbf{3 -}} \\
\left(\mathbf{m g . l}^{\mathbf{- 1}}\right)\end{array}$ \\
\hline Entrada & 182 & 0,089 & 8,0 \\
P0 & 149 & 0,318 & 11,6 \\
P1 & 68 & 0,122 & 9,6 \\
P2 & 61 & 0,044 & 7,4 \\
P3 & 49 & 0,060 & 7,4 \\
Topo & 55 & 0,059 & 8,8 \\
Saída & 46 & 0,054 & 7,2 \\
\hline
\end{tabular}

A Figura 5.46 e a Figura 5.47 apresentam a variação na concentração de sólidos suspensos totais no fundo do reator e no ponto de amostragem a dois metros de altura. Esses gráficos ilustram, resumidamente, a dificuldade em manter a expansão da manta de lodo estável.

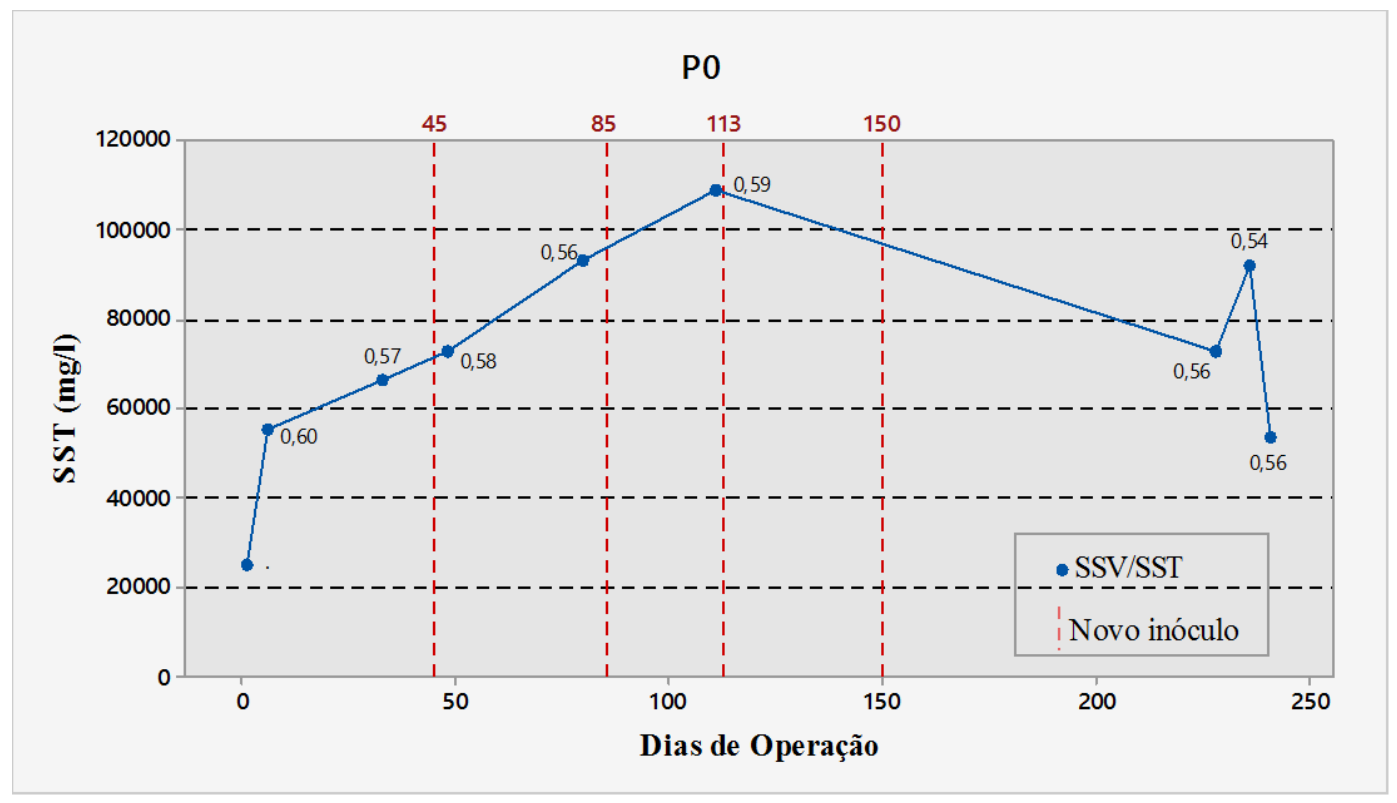

Figura 5.46: Variação na concentração de sólidos suspensos junto ao fundo do reator. 


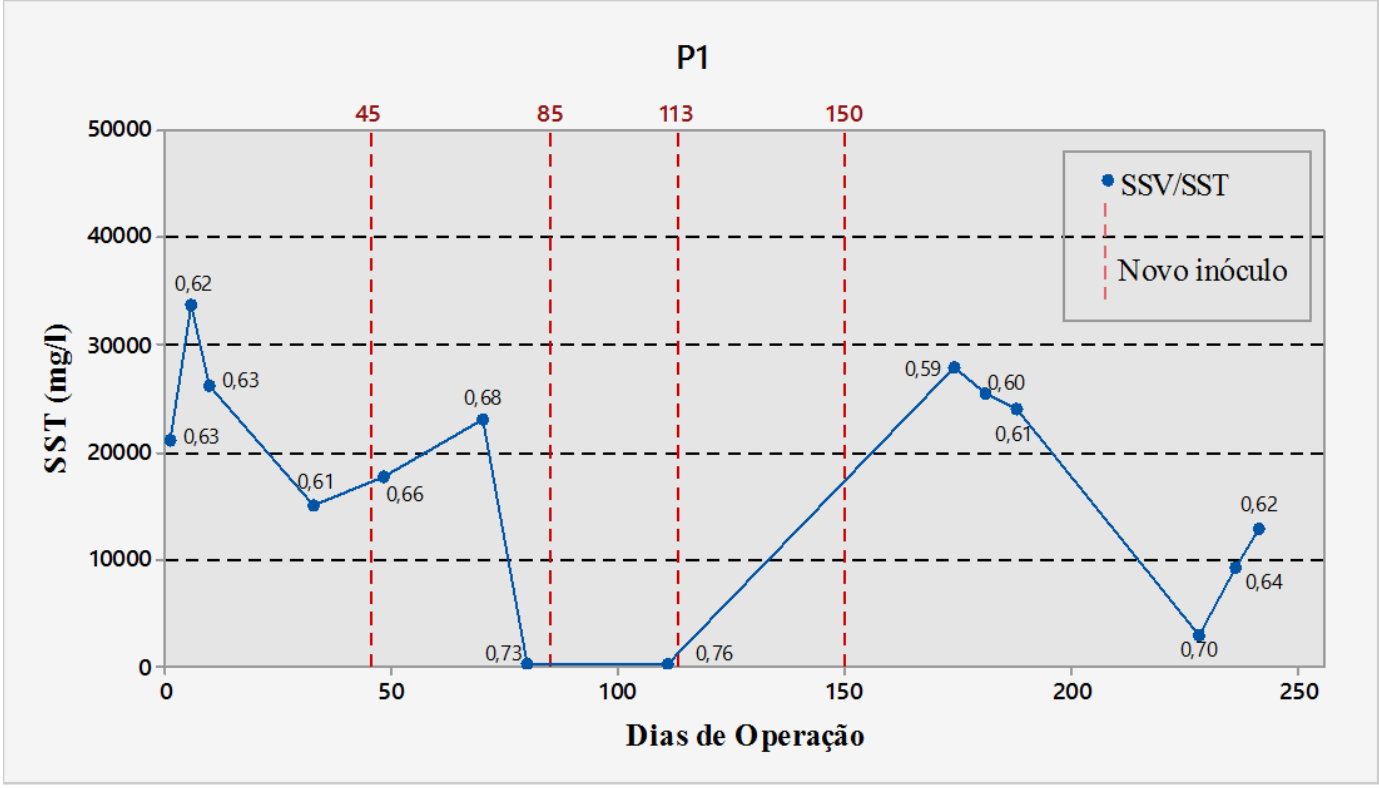

Figura 5.47: Variação da concentração de sólidos suspensos para 2,0 m de altura.

Ainda que a concentração de sólidos suspensos tenha sofrido grandes variações ao longo do tempo, em diversos momentos a concentração no ponto P1 (2,0 m do fundo) foi superior a $5.000 \mathrm{mg} . \mathrm{l}^{-1}$, indicando a presença da manta de lodo. Na Figura 5.48 é apresentada uma adaptação do perfil de sólidos suspensos de um reator UASB tradicional, com dados retirados de Agricultural University of Wageningen (1994); nota-se que as concentrações de sólidos no fundo e a 2,0m do fundo são similares às encontradas no reator objeto desta pesquisa.

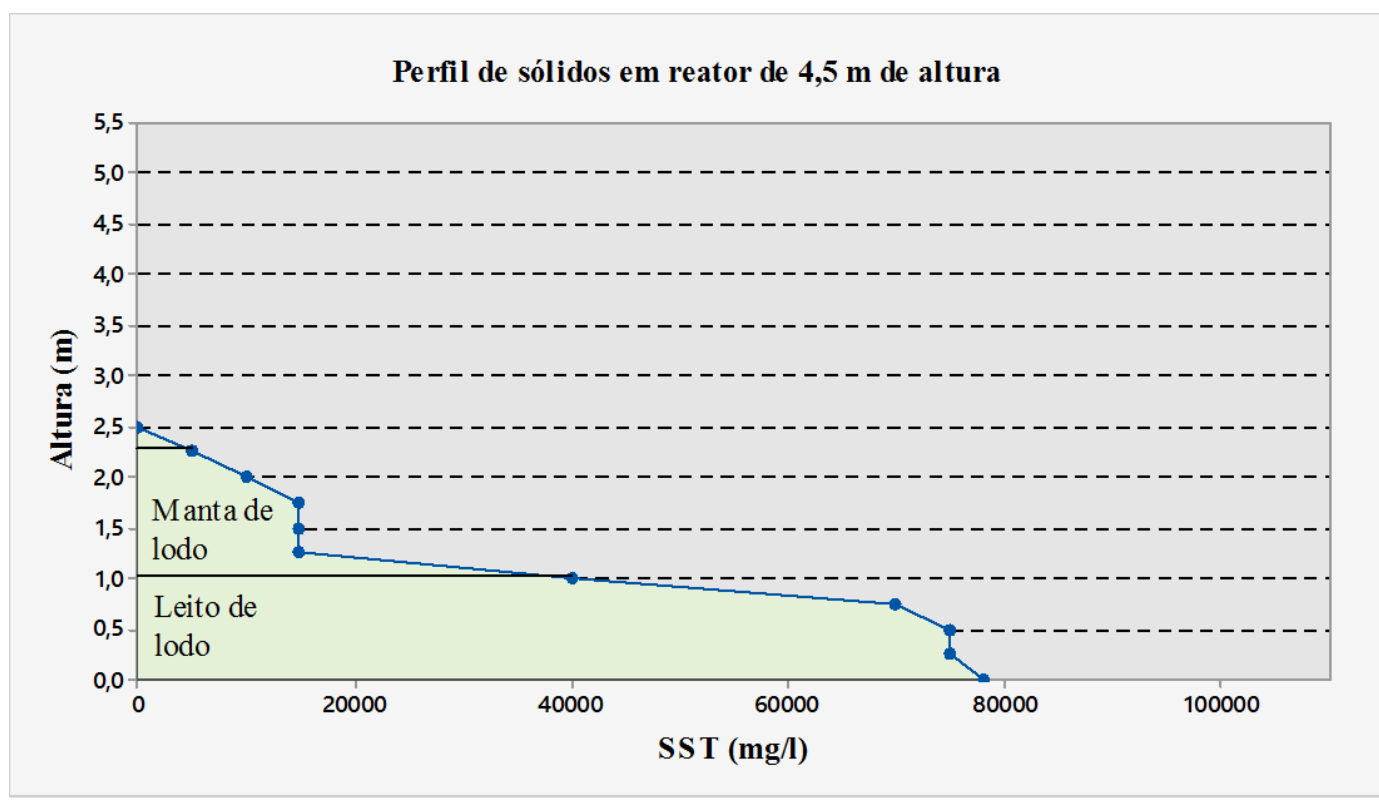

Figura 5.48: Perfil de sólidos de um reator UASB tradicional (adaptado de Agricultural University Of Wageningen, 1994). 
Um parâmetro que pode ter influenciado na expansão da manta de lodo foi a variação da temperatura. Na Figura 5.49 são apresentados os valores médios de temperatura ambiente para o período de operação do sistema. Após 150 dias de operação, foram verificadas temperaturas médias continuamente acima de $20{ }^{\circ} \mathrm{C}$, o que favoreceu a atuação dos microorganismos presentes na manta de lodo.

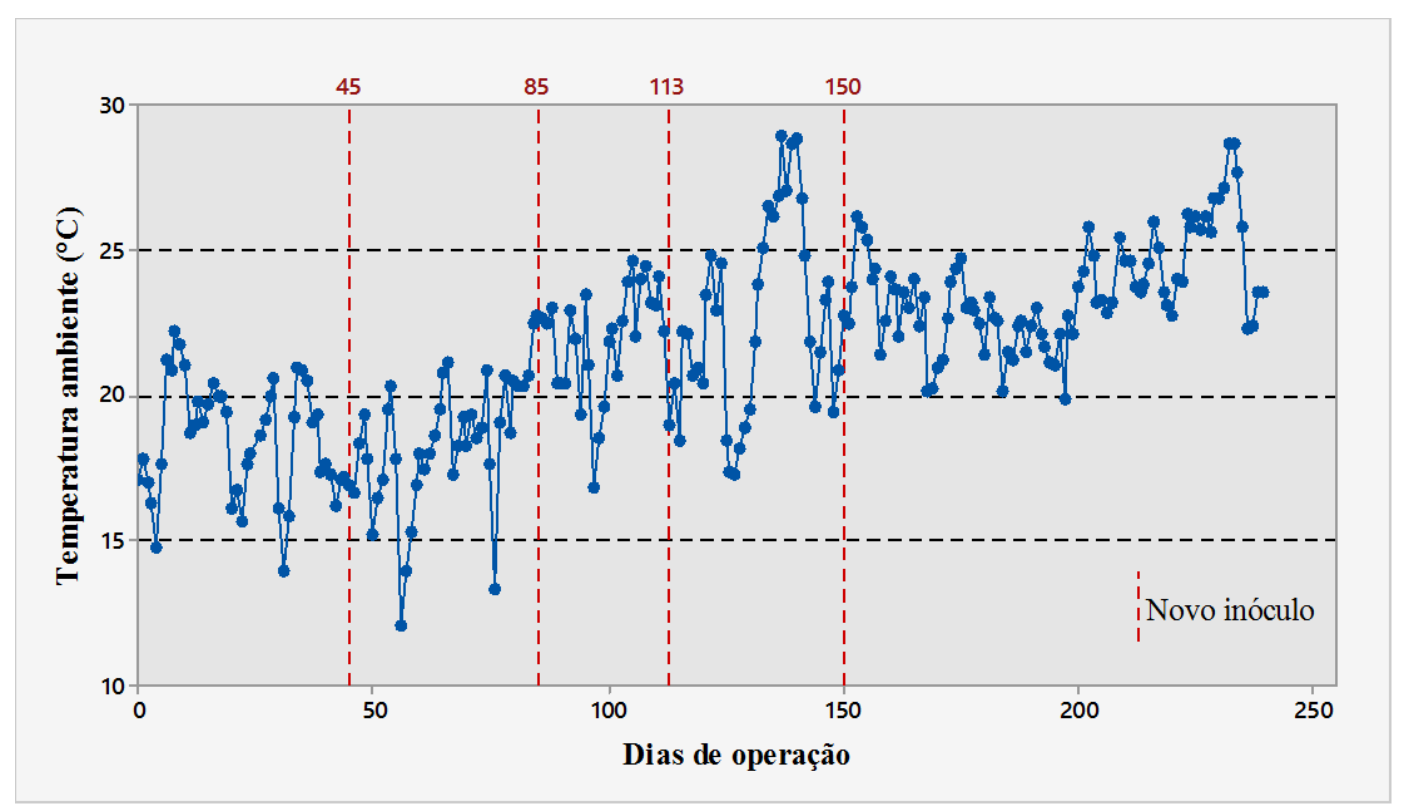

Figura 5.49: Valores diários da temperatura ambiente média.

Esperava-se que uma manta de lodo mais espessa pudesse aumentar a degradação da matéria orgânica do esgoto, porém, como foi observado o no item 5.4.3 (monitoramento do sistema), essa degradação manteve-se relativamente homogênea, independente das condições operacionais adotadas.

Na Tabela 5.14 são apresentados os resultados para o ensaio de atividade metanogênica. A duração de cada ensaio foi de 12 horas visando simular as condições reais de degradação da matéria orgânica que ocorriam no reator. Dessa forma, não atingiu-se, a atividade metanogênica diária máxima, valor que geralmente é apresentado em outros trabalhos. Destaca-se que a atividade do lodo diminuiu nas amostras do fundo do reator. Acredita-se que essa diminuição seja decorrente da baixa carga orgânica no afluente.

Na porção superior da manta (2,0 m de altura), a atividade específica foi mais elevada, porém a baixa concentração de sólidos suspensos contribui para reduzida remoção de matéria orgânica nessa porção do reator, como foi indicado nos perfis de remoção apresentados na Tabela 5.11, Tabela 5.12 e Tabela 5.13. 
Tabela 5.14: Resultados dos ensaios de AME

\begin{tabular}{ccccc}
\hline Lodo & Dias de operação & TDH & $\begin{array}{c}\text { SSV } \\
\text { mg. }^{\mathbf{1}}\end{array}$ & $\begin{array}{c}\text { AME } \\
\text { mg DQO } \text { rem } \cdot \mathbf{g ~ S S V}^{-1}\end{array}$ \\
\hline Inóculo & - & - & 13.940 & 33,50 \\
P0 & 228 & $12 \mathrm{~h}$ & 40.642 & 17,99 \\
P0 & 241 & $8 \mathrm{~h}$ & 30.262 & 20,80 \\
P1 & 241 & $8 \mathrm{~h}$ & 8.034 & 39,17 \\
\hline
\end{tabular}

5.4.6 Pós-tratamento do efluente do sistema - filtro rápido de areia

O desempenho do filtro de areia como pós-tratamento do efluente do reator UASB foi avaliado em termos da remoção da DQO, SST, Turbidez e Cor. Essa avaliação foi realizada após 190 dias de operação do sistema anaeróbio, e, após 15 dias de operação do filtro. As médias de remoção e dos valores de entrada e saída dessas variáveis estão apresentados na Tabela 5.15.

Tabela 5.15: Desempenho, durante uma carreira, do filtro de areia como pós-tratamento ao efluente do sistema anaeróbio de manta de lodo.

\begin{tabular}{ccccc}
\hline Variável & $\begin{array}{c}\text { Número } \\
\text { de } \\
\text { amostras }\end{array}$ & Entrada & Saída & Remoção \\
\hline DQO & 7 & $147\left(\mathrm{mg} . \mathrm{l}^{-1}\right)$ & $66\left(\mathrm{mg} . \mathrm{l}^{-1}\right)$ & $54,94 \pm 12,33 \%$ \\
bruta & & $58\left(\mathrm{mg} . \mathrm{l}^{-1}\right)$ & $9\left(\mathrm{mg} . \mathrm{l}^{-1}\right)$ & $84,44 \pm 4,55 \%$ \\
SST & 7 & $52,5(\mathrm{NTU})$ & $9,41(\mathrm{NTU})$ & $81,85 \pm 5,12 \%$ \\
Turbidez & 7 & $443\left(\mathrm{mg} . \mathrm{l}^{-1} \mathrm{Pt}-\mathrm{Co}\right)$ & $152 \mathrm{Pt}-\mathrm{Co}$ & $65,29 \pm 8,20 \%$ \\
Cor & 7 & & &
\end{tabular}

Na Figura 5.50 são apresentados os valores de DQO na entrada e saída do filtro. Os valores de DQO das amostras no efluente filtrado estiveram em torno de $50 \mathrm{mg} . \mathrm{l}^{-1}$, o que significa um efluente de boa qualidade. 


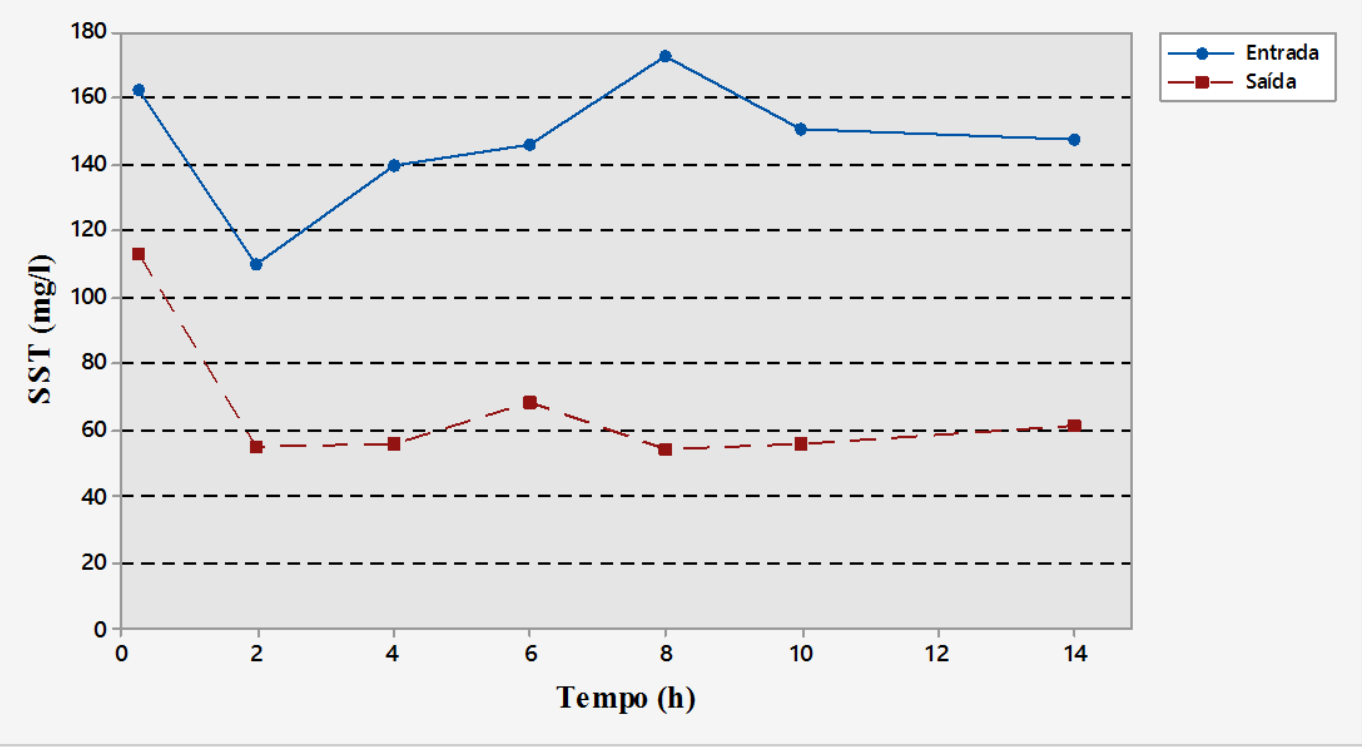

Figura 5.50: Valores de DQO na entrada e saída do filtro de areia.

Na Figura 5.51 são apresentadas as eficiências de remoção para DQO. Essas eficiências tiveram grande oscilação, mas destaca-se o ponto onde houve remoção de DQO perto de 70\%, valor bem elevado para um filtro de alta taxa.

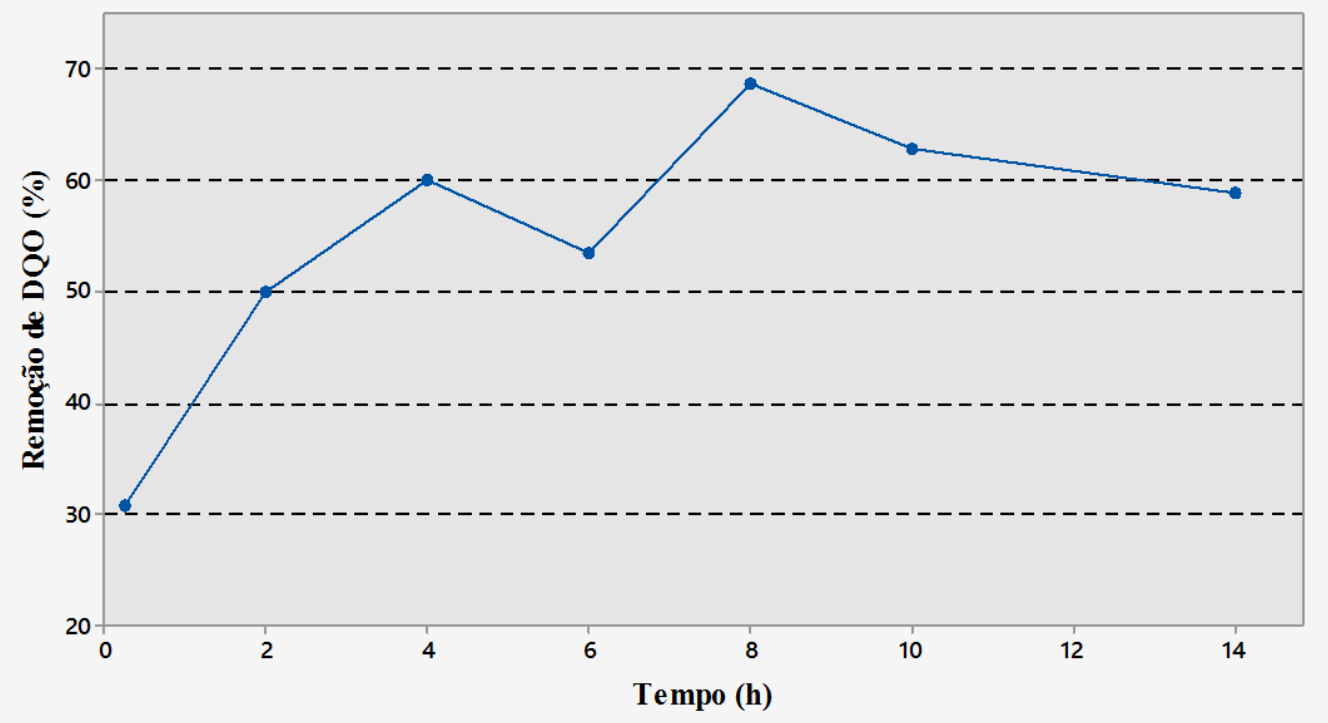

Figura 5.51: Eficiência de remoção de DQO no filtro de areia. 
Na Figura 5.52 são apresentados os valores de sólidos suspensos totais do afluente e do filtrado. Observa-se que, com exceção de duas amostras, os valores de saída estiveram menor ou igual a $8 \mathrm{mg} \cdot \mathrm{l}^{-1}$. Esse valor é consoante com o encontrado por Asano et al (2007).

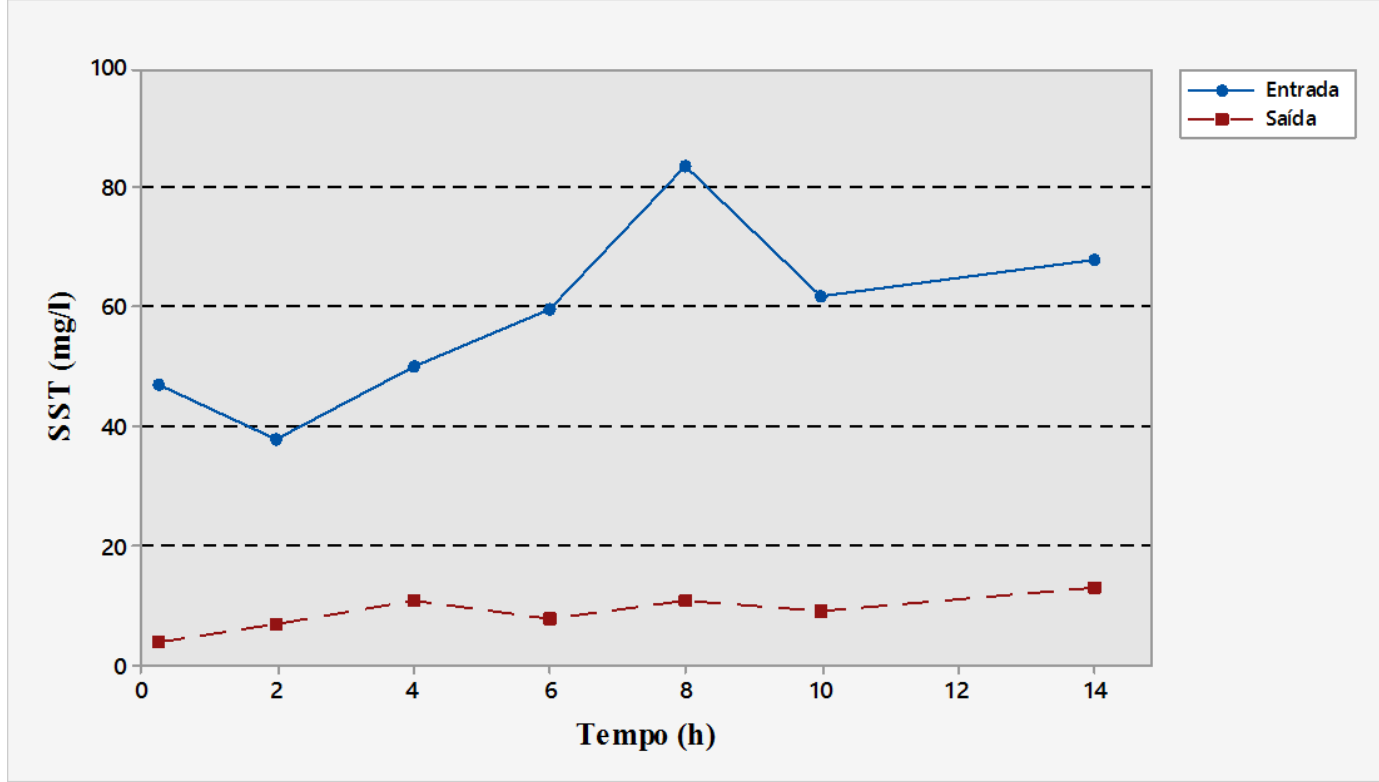

Figura 5.52:Concentração de SST para entrada e saída do filtro de areia.

Na Figura 5.53 são apresentadas as eficiências de remoção de sólidos suspensos no filtro de areia. As remoções foram muito elevadas, em média de 84,44\%.

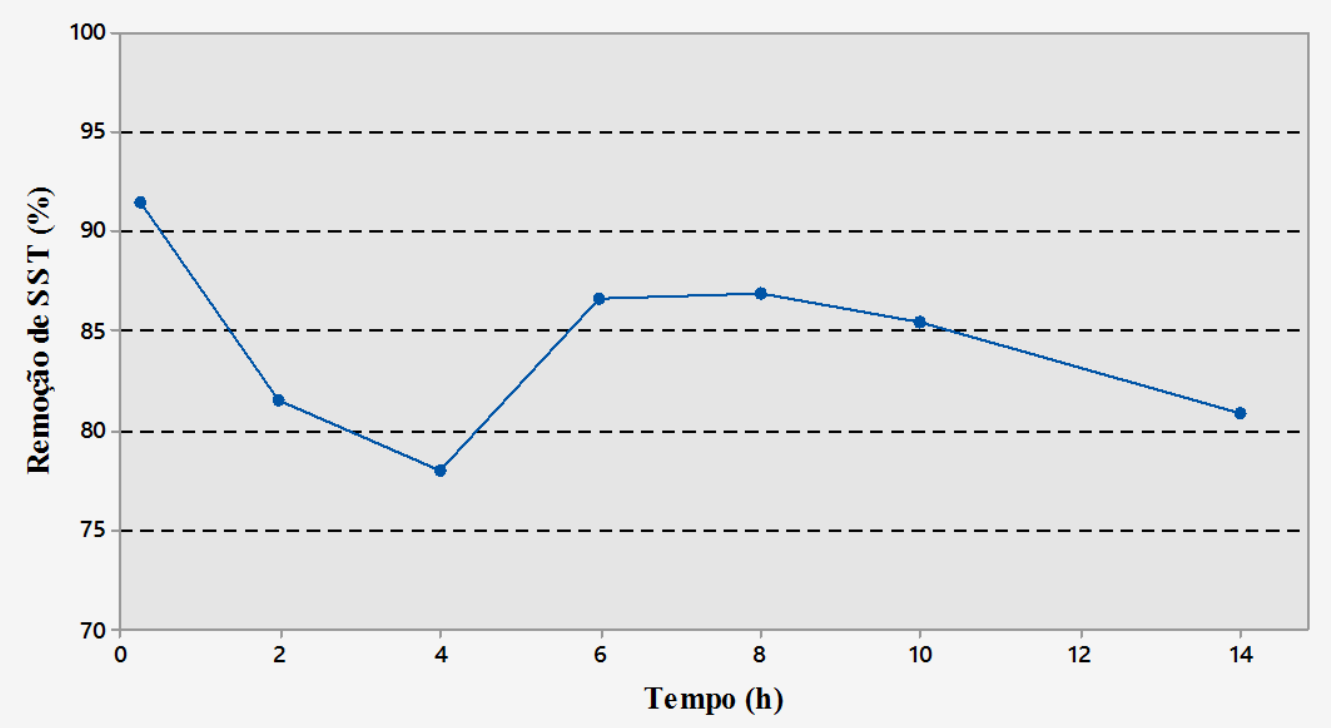

Figura 5.53: Eficiência de remoção de sólidos suspensos totais no sistema de filtração. 
Os valores de turbidez na entrada e saída dos filtros são apresentados na Figura 5.54. Os valores de saída estiveram sempre próximos a 10 NTU, o que representa um resultado muito satisfatório para filtração sem adição de coagulantes. Tchobanaglous et al (2004) relatam que o valor mínimo que a turbidez pode atingir sem adição de coagulantes é entre 5 e 7 NTU. Na Figura 5.55 destaca-se que as eficiências de remoção de turbidez estiveram sempre acima de $75 \%$.

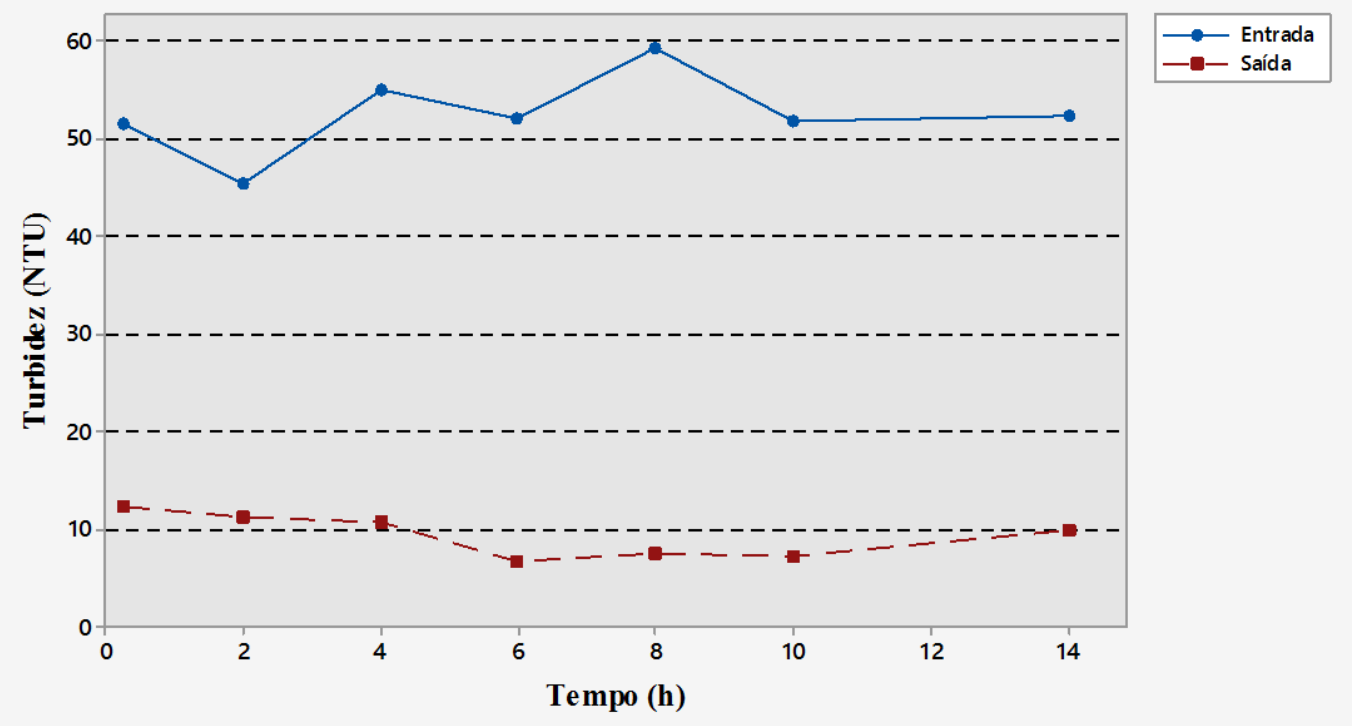

Figura 5.54: Valores de turbidez na entrada e saída do filtro de areia.

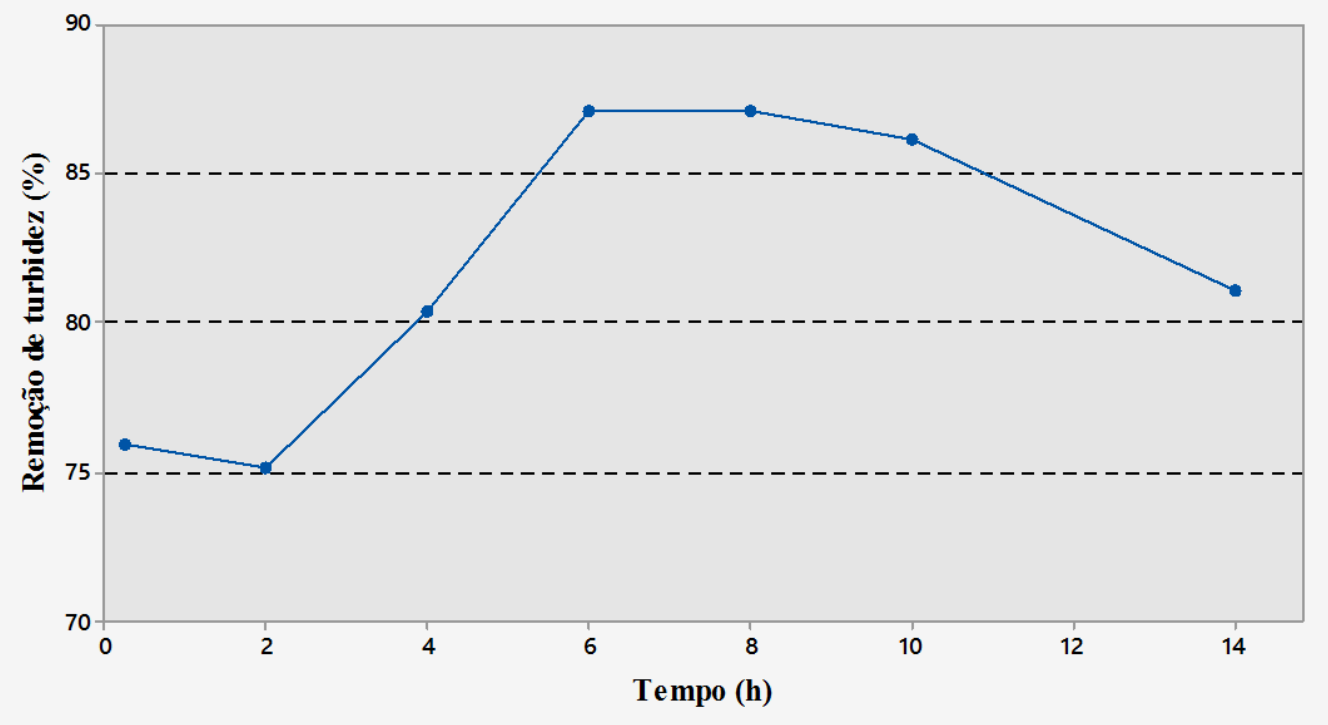

Figura 5.55: Eficiência de remoção de turbidez no pós-tratamento por filtro de areia. 
Ao analisar o gráfico com as perdas de carga, Figura 5.56, nota-se que a filtração deuse apenas por ação superficial. Segundo Di Bernardo e Paz (2008), em ocorrências desse tipo não há ação dos mecanismos de filtração em profundidade (transporte, aderência e desprendimento). Acredita-se que a heterogeneidade no tamanho dos grãos da areia (apesar do tamanho efetivo de 1,00 mm) foi responsável por criar uma camada de grãos muito finos na superfície do leito de filtração, que tinha grande facilidade de colmatação. Jago (1977) também relatou dificuldades em fazer a frente de impurezas penetrar além da camada superficial do meio filtrante, utilizando filtros por gravidade

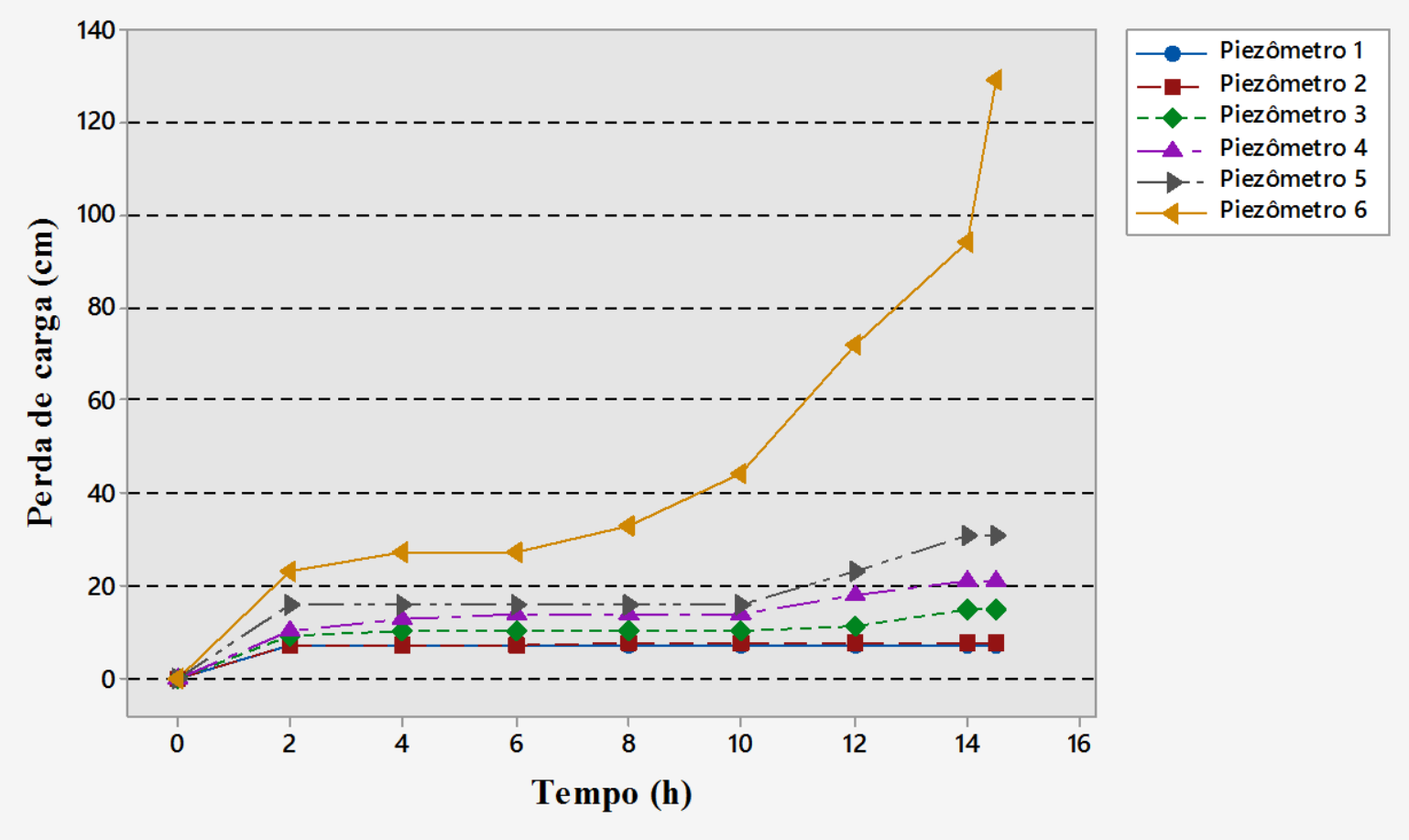

Figura 5.56: Perda de carga medida ao longo do leito de filtração.

O efluente tratado com filtro rápido de areia apresentou valores de saída satisfatórios para DQO, SST e turbidez. O tempo de duração da carreira, em torno de 14 horas, também foi razoável. Destaca-se que esses resultados foram atingidos através da filtração superficial do efluente. Com a adoção de meio filtrante homogêneo, esses resultados (tanto de tratamento como de tempo de duração da carreira de filtração) podem ser otimizados. 


\subsection{Exemplo teórico de scale-up}

Utilizando o roteiro descrito no item 4.4.4.1 estimou-se, teoricamente, as características necessárias a um reator para tratar $1500 \mathrm{~m}^{3}$ de esgoto sanitário por dia.

Para isso adotou-se aplicação de gradiente de velocidade de $20 \mathrm{~s}^{-1}$, volume do reator de $500 \mathrm{~m}^{3}$, TDH de 8 horas, e 4 bocais com características semelhantes às usadas nesta pesquisa $(\mathrm{CD}=0,82)$ para alimentar um reator quadrado de $100 \mathrm{~m}^{2}$ de área. A carga manométrica aplicada no bocal foi definida para 1,20 m.

Ao se adotar o gradiente de velocidade de $20 \mathrm{~s}^{-1}$, através da Equação 4.2 tem-se que a potência hidráulica necessária para tal agitação deve ser de $1960 \mathrm{~W}$, que significa 3,92 W.m-3.

Para carga manométrica de 1,20 m, tem-se que a vazão de descarga para fornecer essa potência deve ser de $0,166 \mathrm{~m}^{3} \cdot \mathrm{s}^{-1}$ (Equação 4.1). Para tempo de detenção de 8 horas, a vazão média afluente é de $0,0173 \mathrm{~m}^{3} \cdot \mathrm{s}^{-1}$, o que significa que a vazão de descarga é 9,6 vezes maior que a afluente. Para satisfazer essa condição de descarga o afluente pode ser armazenado por 4 minutos e ser descarregado em 25 segundos. Dessa forma será preciso um reservatório de volume 4590 litros.

Como foi definido o uso de 4 bocais semelhantes ao desta pesquisa, cada bocal deverá estar apto a descarregar uma vazão de $0,0415 \mathrm{~m}^{3} . \mathrm{s}^{-1}$. Utilizando-se a Equação 4.3 tem-se um bocal com diâmetro de $115 \mathrm{~mm}$ na seção contraída, e de $175 \mathrm{~mm}$ de diâmetro na seção de saída. Isso dá uma velocidade de $1,72 \mathrm{~m} \cdot \mathrm{s}^{-1}$ na saída do bocal. Para aumentar a velocidade e o alcance desse jato, poder-se-ia eliminar a zona de expansão do bocal, visto que a velocidade na seção contraída, para este caso exemplificado, é de 4,0 m.s ${ }^{-1}$. Caso essa mudança no formato do bocal seja realizada, é necessário que se façam novos testes para avaliar se o coeficiente de descarga sofreria alguma mudança.

\subsection{Análise crítica}

Na primeira fase da pesquisa ficou evidente que a energia aplicada no reator deve ser baixa, pois do contrário o aporte de lodo ao decantador é elevado, inviabilizando o sistema de decantação e retorno de lodo. O gradiente de velocidade $(G)$ para se manter a manta estratificada em reatores anaeróbios é relativamente baixo, em torno de $20 \mathrm{~s}^{-1}$ para operação de rotina. No 
reator piloto da terceira fase, foi utilizada essa faixa de gradiente de velocidade indicada nos resultados das fases anteriores, e conseguiu-se obter uma energia aplicada de 2,7 W.m-3 . Esse valor está dentro da faixa de potência $\left(2\right.$ a $\left.5 \mathrm{~W} . \mathrm{m}^{-3}\right)$ relatada por Nahle (1991) para promover mistura mecânica em digestores anaeróbios de lodo.

Na segunda etapa de operação do sistema piloto da fase 3 foi aplicado uma vazão de segurança para tempo de detenção hidráulica de 12 horas. Porém esse tempo de detenção é um valor médio, visto que o tempo de descarga é controlado pelo nível do reservatório, e, portanto, a vazão de descarga e potência aplicada é sempre a mesma. O que difere quando se opera com um tempo de detenção médio de 8 ou 12 horas é o intervalo entre as descargas.

Para a construção do sistema piloto da fase 3 desta pesquisa foi utilizado a estrutura de um reator UASB que havia sido operado anteriormente por diversos pesquisadores da ESSC/USP. A última pesquisa realizada no reator UASB com a concepção tradicional, e com o mesmo efluente, foi realizada por Medeiros (2013). Na tabela 5.16 são comparados os dados obtidos nesta pesquisa com os dados de Medeiros (2013).

Tabela 5.16: Comparação dos dados de DQO e SST entre o sistema experimental e reator UASB experimental da EESC/USP.

\begin{tabular}{|c|c|c|c|c|}
\hline & \multicolumn{2}{|c|}{ DQO } & \multicolumn{2}{|c|}{ SST } \\
\hline & $\begin{array}{c}\text { Sistema Piloto } \\
\mathrm{TDH}=12 \mathrm{~h}\end{array}$ & $\begin{array}{c}\text { Medeiros } \\
\text { (2013) } \\
\text { TDH = } 12 \text { h }\end{array}$ & $\begin{array}{c}\text { Sistema Piloto } \\
\mathrm{TDH}=12 \mathrm{~h}\end{array}$ & $\begin{array}{c}\text { Medeiros } \\
\text { (2013) } \\
\text { TDH = } 12 \text { h }\end{array}$ \\
\hline Entrada (mg.l $\left.{ }^{-1}\right)$ & 332 & $1131 \pm 1197$ & 115 & $501 \pm 833$ \\
\hline Saída (mg.l $\left.{ }^{-1}\right)$ & 153 & $316 \pm 158$ & 59 & $103 \pm 52$ \\
\hline Remoção (\%) & 52 & 57 & 47 & 48 \\
\hline
\end{tabular}

Os dados de DQO e SST apresentados na Tabela 5.17 mostram como as características do esgoto afluente mudaram drasticamente. A taxa de carregamento orgânico volumétrico média foi de apenas $0,66 \mathrm{~kg} \cdot \mathrm{m}^{-3} \cdot \mathrm{dia}^{-1}$. A COV média na pesquisa de Medeiros (2013) teve valor de 2,2 kg.m $\mathrm{m}^{-3} \cdot \mathrm{dia}^{-1}$. Segundo Lettinga (1993) reatores com afluente de baixa carga orgânica $\left(\mathrm{COV}<2,0 \mathrm{~kg} \cdot \mathrm{m}^{-3}\right.$.dia $\left.{ }^{-1}\right)$ devem ter entradas muito próximas para terem bom desempenho. Entretanto, a eficiência do sistema piloto, em termos de remoção de DQO e SST, foi semelhante à pesquisa em que foi utilizado afluente com uma carga orgânica elevada. Uma hipótese que 
pode ser abordada é que as eficiências de remoção do sistema piloto poderiam ser maiores caso fosse utilizado um esgoto "forte".

$\mathrm{Na}$ Tabela 5.17, os resultados de DQO e SST encontrados no sistema da fase 3 foram comparados com os valores médios levantados na bibliografia de mais de 50 reatores UASB utilizados em estações de tratamento de esgoto sanitário em escala plena (apresentados na Tabela 3.3, no item 3.2.3).

Nota-se que os percentuais de remoção dessas duas variáveis foram muito próximos para o sistema experimental e para os reatores UASB, destacando-se ainda que no sistema experimental o efluente final apresentou uma qualidade superior.

Tabela 5.17: Comparação dos dados de DQO e SST entre o sistema experimental e reatores UASB escala plena relatados no item 3.2.3.

\begin{tabular}{|c|c|c|c|c|}
\hline & \multicolumn{2}{|c|}{ DQO } & \multicolumn{2}{|c|}{ SST } \\
\hline & $\begin{array}{c}\text { Sistema Piloto } \\
\text { TDH }=12 \text { h }\end{array}$ & $\begin{array}{c}\text { Estações } \\
\text { Escala Plena }\end{array}$ & $\begin{array}{c}\text { Sistema Piloto } \\
\mathrm{TDH}=12 \mathrm{~h}\end{array}$ & $\begin{array}{c}\text { Estações } \\
\text { Escala Plena }\end{array}$ \\
\hline Entrada $\left(\mathrm{mg.l}^{-1}\right)$ & 332 & 534 & 115 & 268 \\
\hline Saída $\left(\mathrm{mg.l}^{-1}\right)$ & 153 & 233 & 59 & 122 \\
\hline Remoção (\%) & 53 & 58 & 47 & 58 \\
\hline
\end{tabular}

O emprego de jatos intermitentes exige a construção de um tanque pulmão com nível mínimo de esgoto cerca de 1,8 m acima do nível interno no reator anaeróbio. Normalmente, para sistemas de distribuição convencionais, esse nível é geralmente próximo a 1,0 m. Isso implica em dispêndio adicional de energia, quando a estação de tratamento de esgoto é alimentada com esgoto recalcado; pois a altura manométrica deverá ser elevada em 1,0 m ou mais.

Nos reatores das fases 2 e 3, ficou evidente que a operação deve ocorrer, obrigatoriamente, 24 horas por dia sem interrupção. Constatou-se que após período sem alimentação, ao se reiniciar a chegada de esgoto há maior produção de gases com a formação de grandes bolsões que "estouravam" na superfície do reator e provocavam, consequentemente, arraste de lodo. Esse tipo de ocorrência havia sido relatado por Leitão et al (2006). O uso de jatos intermitentes é favorável a remoção desses bolsões, pois a elevada vazão de descarga impede esses acúmulos de gases. 
Em relação a carreira de filtração do filtro rápido de areia, o tempo entre lavagens poderia ser melhorado caso a granulometria fosse mais homogênea. Ficou claro que apesar de ser utilizado um leito filtrante com diâmetro efetivo e coeficiente de não-uniformidade semelhantes aos relatados na literatura — Henriquez (1988), Prezzoti (1990) —, é necessário também que a variação entre o tamanho dos maiores e menores grãos seja pequena.

O sistema proposto obteve bons índices de tratamento, utilizando baixo uso de equipamentos sofisticados e consumo energético, mostrando sua viabilidade para o tratamento de esgoto sanitário. 


\section{CONCLUSÕES}

O uso do sistema anaeróbio de manta de lodo, com agitação proveniente de bocais e dotado de decantador de alta taxa indicou grande potencialidade para tratamento de esgoto sanitário no que tange à remoção de matéria orgânica e remoção de sólidos suspensos.

A agitação proporcionada com o uso de jatos intermitentes foi suficiente para manter a manta de lodo do reator anaeróbio com características semelhantes àquelas que se encontram em reatores UASB convencionais. Vale salientar que o gradiente de velocidade aplicado de $16,6 \mathrm{~s}^{-1}$ durante a descarga (com duração de $30 \mathrm{~s}$ ) foi suficiente para promover a mistura entre afluente e biomassa, e o sistema de filtração em areia demonstrou ser boa opção para o póstratamento do efluente do reator, produzindo efluente final com concentrações médias de 66 mg. $1^{-1}$ para DQO e 9 mg..$^{-1}$ para SST.

O uso do dispositivo de decantação laminar mostrou eficiência elevada (89,3\%) na remoção de sólidos suspensos, mostrando que o reator pode operar adequadamente mesmo eliminando o sistema de separação trifásico e o complexo sistema de alimentação.

O mecanismo de retorno do lodo da zona de decantação para o fundo da zona de reação pode ser configurado como um componente de um sistema anaeróbio de lodos ativados. O sistema inovador proposto nessa pesquisa promoveu tratamento do esgoto sanitário com eficiência média de 70,9\% em termos de DBO.

Por fim, destaca-se a flexibilidade operacional do sistema de agitação com bocais, pois os níveis mínimo e máximo do reservatório, assim como as perdas de carga do sistema de alimentação, podem ser ajustados de modo a se variar a intensidade da energia aplicada no reator. Esse fato permite a manutenção da manta de lodo mais próximas às condições ideais, a partir de cada caso em específico. 
Página intencionalmente deixada em branco. 


\section{SUGESTÕES}

Os ensaios realizados durante o trabalho comprovaram a potencial viabilidade de tratamento utilizando a nova concepção de sistema anaeróbio de manta de lodo.

Como próximo passo para desenvolvimento do sistema propõe-se a construção de um reator com maior área e volume, para teste do alcance dos jatos misturadores e eficiência do tratamento nessas condições.

Ademais, sugere-se o uso de ferramentas computacionais de análise fluidodinâmica, para o estudo do arranjo ideal dos bocais no interior do reator em escala plena. 
Página intencionalmente deixada em branco. 


\section{REFERÊNCIAS BIBLIOGRÁFICAS}

AGRAWAL, L. K.; HARADA, H.; TSENG, I.; OKUI, H. Treatment of dilute wastewater in a UASB reactor at a moderate temperature: microbiological aspects. Journal of Fermentation and Bioengineeering. v. 83, n. 2, p. 185-190, 1997.

AGRICULTURAL UNIVERSITY OF WAGENINGEN. Decom manual: Manual for the design, construction, operation and maintenance of uasb treatment plants for domestic wastewater. A2820.24/R16A/WMW/JLH. Directorate general of International Cooperation (DGIS), Holland, 1994. 150 p.

AIYUK, S.; FORREZ, I.; LIEVEN, K.; VAN HAANDEL, A.; VERSTRAETE, W. Anaerobic and complementary treatment of domestic sewage in regions with hot climates: a review. Bioresource Technology. v. 97, p. 2225-2241, 2006.

AMERICAN WATER WORKS ASSOCIATION. Water quality \& treatment: a handbook of comunity water supplies. $5^{\text {a }}$ edição. Nova York. McGraw-Hill, 1999. 1849 p.

ANDREOLI, C. V.; VON SPERLING, M.; FERNANDES, F. (Eds). Lodo de esgotos: tratamento e disposição final. Belo Horizonte. Editora UFMG, 2001. 484 p.

APHA, WEF, AWWA. Standard methods for the examination of water and wastewater. $21^{\mathrm{a}}$ edição. 2005.

AQUINO, S. F.; CHERNICHARO, C. A.; FORESTI, E.; SANTOS, M.L.F.; MONTEGGIA, L. O. Metodologias para determinação da Atividade Metanogênica Específica (AME) em lodos anaeróbios. Engenharia Sanitária e Ambiental. v. 12, p. 192-201, 2007.

ASANO, T.; BURTON, F. L.; LEVERENZ, H. L.; TSUCHIHASHI, R.; TCHOBANAGLOUS, G. Water reuse: issues, technologies and applications. McGraw Hill, 2007. 1570p.

ASSOCIAÇÃO BRASILEIRA DE NORMAS TÉCNICAS. NBR 7.181: Solo - análise granulométrica. São Paulo, 1984. 13p.

ASSOCIAÇÃO BRASILEIRA DE NORMAS TÉCNICAS. NBR 12.209: Elaboração de projetos hidráulico-sanitários de estações de tratamento de esgotos sanitários. São Paulo, 2011. 53p. 
ATIEMO-OBENG, V. A.; PENNEY, W. R.; ARMENANTE, P. Solid-Liquid Mixing. In: PAUL, E.; ATIEMO-OBENG, V. A.; KRESTA, S. M., Ed(s). Handbook of industrial mixing. Hoboken: John Wiley \& Sons, p. 543-584, 2004.

AZEVEDO NETTO, J. M. Manual de hidráulica. $8^{a}$ edição. São Paulo. Edgard Buncher Ltda, 1998. 669p.

BRINCK, N. C. P. Avaliação do tipo de material filtrante no comportamento hidráulico de filtros rápidos de camada profunda no tratamento de águas de abastecimento. São Paulo, 2009. Tese (Doutorado em Engenharia Hidráulica e Sanitária). Universidade de São Paulo.

CALIJURI, M. C.; CUNHA, D. G. F. Engenharia ambiental: conceitos, tecnologia e gestão. Editora Campus, 2012. 832p.

CHELLAPANDI, P.; PRABAHARAN, D.; UMA, L. Evaluation of methanogenic activity of biogas plant slurry for monitoing codigestion of ossein factory wastes and cyanobacterial biomass. Applied Biochemical and Biotechnology. v. 162, p. 524-535, 2010.

CHERNICHARO, C. A. L. Reatores anaeróbios. Belo Horizonte. Departamento de Engenharia Sanitária e Ambiental, 1997. 246p.

CHERNICHARO, C. A. L.; STUETZ, R. M. Improving the design and operation of UASB reactors for treating domestic wastewater: management of gaseous emissions. IN: IX Latin American Workshop and Symposium on Anaerobic Digestion, 2008, Isla de Pascua. Proceedings of the IX Latin American Workshop and Symposium on Anaerobic Digestion, 2008. p. $1-8$.

DE ZEEUW. Aclimatization of anaerobic sludge for UASB reactor start-up. Wageningen (Netherlands), 1984. Tese (Doutorado). Wageningen Agricultural University.

DI BERNARDO, L. Projeto de sistemas de filtração para tratamento de águas de abastecimento. São Carlos, 1988, Universidade de São Paulo.

DI BERNARDO, L.; PAZ, L. P. S. Seleção de tecnologias de tratamento de água. São Carlos. LDIBE editora, 2001. 1538p. 
DILALLO, R.; ALBERTSON, O. E. Volatile acids by direct titration. Journal of Water Pollution Control Federation, v. 33, n.4, p. 356-356. 1961.

DOLFING, J. Granulation in UASB reactors. Water Science and Technology. v. 18, p. 15-25, 1986.

ELMITWALLI, T. Mathematical modelling of Upflow Anaerobic Sludge Blanket (UASB) reactor treating domestic wastewater. Water Science and Technology. v. 67, p. 24-32, 2013.

FREIRE, M. L. Influência da altura de queda de água entre as unidades de pré-tratamento e os filtros de uma ETA, e da taxa de filtração na duração da carreira de filtração e na qualidade do efluente. São Carlos, 1983. Tese (Mestrado em Hidráulica e Saneamento). Universidade de São Paulo.

GARCIA, G. P.; SOUZA, C. L.; GLÓRIA, R. M.; SILVA, S. Q.; CHERNICHARO, C. A. L. Biological oxidation of sulphides by microorganisms present in the scum layer of UASB reactors treating wastewater. Water Science and Technology. v. 66, n. 9, p. 1871-1878, 2012.

GERARDI, M. H. The microbiology of anaerobic digesters. $1^{a}$ edição. New Jersey. John Wiley \& Sons Inc, 2003. 177p.

GIORGETTI, M. F. Fundamentos de fenômenos de transporte para estudantes de engenharia. São Carlos: Suprema, 2008.

GOBBI, S. A. Remoção de ovos de helmintos de esgotos secundários, por meio de filtros rápidos de areia, carvão antracitoso e zeólito para reuso agrícola e urbano não potável. São Paulo, 2010. Tese (Mestrado em Engenharia Hidráulica e Saneamento). Universidade de São Paulo.

GUIOT, S. R.; KENNEDY, J. K.; VAN DER BERG, L. Comparation of the upflow anaerobic sludge blanket and sludge bed filter. IN: Taller y Seminario Latinoamericano Tratamento Anaeróbio de Águas Residuales 5. 1986. Viña Del Mar, Chile. Anais do Taller y Seminario Latinoamericano Tratamento Anaeróbio de Águas Residuales 5.

HAMODA, M. F.; AL-GHUSAIN, N. Z. AL-MUTAIRI. Sand filtration of wastewater for tertiary treatment and water reuse. Dessalination. v. 164, p. 203-211, 2004.

HARNBY, N.; EDWARDS, M. F.; NIENOW, A. W. Mixing in the process industries. ButterHeinemann, Digital Printing 2001. 
HEFFERNAN, B.; VAN LIER, J. B.; VAN DER LUBBE, J. Performance review of large scale up-flow anaerobic sludge blanket sewage treatment plants. Water Science and Technology. v. 63 , n. 1, p. 100-107, 2011.

HENRIQUEZ, J. M. M. Influência da espessura e granulometria no desempenho de sistemas de filtração direta descendente utilizando meio filtrante único de areia. São Carlos, 1988. Tese (Mestrado em Hidráulica e Saneamento). Universidade de São Paulo.

HORI, T.; HARUTA, S.; UENO, Y.; ISHII, M.; IGARASHI,Y. Dynamic of transition of a methanogenic population in response to the concentration of volatile fatty acids in a thermophilic anaerobic digester. Applied and Environmental Microbiology. v. 72, n. 2, 2006.

HULSHOFF POL, L. W.; de ZEEUW, W. J.; VELZEBOER, C. T. M.; LETTINGA, Granulation in UASB-reactors. Water Science and Technology. v. 15, n. 8-9, p 291-304, 1983.

HULSHOFF POL, L. W.; LENS, P. N. L.; STAMS, A. J. M.; LETTINGA, G. Anaerobic treatment of sulphate rich wastewater. Biodegradation. v. 9, p. 213-224, 1998.

JAYANTI, S. Hydrodynamics of jet mixing in vessels. Chemical Engineering Science. v. 56, p. 193-210, 2001.

JAGO, P. H. Review of filtration techniques for tertiary treatment of sewage effluents. Water Research Centre. Technical Reports, TR 64. United Kingdom, 1977.

KATO, M. T.; FIELD, J. A.; VERSTEEG, P.; LETTINGA, G. Feasibility of expanded granular sludge bed reactors for the anaerobic treatment of low-strength soluble wastewaters. Biotechnology Bioengineering. v. 44, p. 469-479, 1984.

KATO, M. T.; FIELD, J. A.; LETTINGA, G. The Anaerobic treatment of low strength wastewaters in UASB and EGSB reactors. Water Science Technology. v. 36, p. 375-382, 1997.

KALAICHELVI, P.; SWARNALATHA, Y.; RAJA, T. Mixing time estimation and analysis in a jet mixer. ARPN Journal of Engineering and Applied Sciences. v. 2, n. 5, p.35-43, 2007.

KHALIL, N.; SINHAB, R.; RAGHAVA, K.; MITTAL, K. UASB technology for sewage treatment in India: experience, economic evaluation and its potential in other developing countries. In: Proceedings of the Twelfth International Water Technology Conference, 2008, Alexandria, p. 1411-1427. 
LEITÃO, R. C.; VAN HAANDEL, A. C.; ZEEMAN, G.; LETTINGA, G. The effects of operational and environmental variations on anaerobic wastewater treatment systems: a review. Bioresource Technology. v. 97, p. 1105-1118, 2006.

LENCASTRE, A. Manual de hidráulica geral. 1ª edição. Lisboa. AEIST, 1957. 342p.

LETTINGA, G.; van VELSEN, A. F. M.; HOBMA, S. W.; de ZEEUW, W.; KLAPWIJK, A. Use of the Upflow Sludge Blanket (USB) concept for biological waste water treatment, especially for anaerobic treatment. Biotechnology and Bioengineering. v. 22, p. 699-734, 1980.

LETTINGA, G.; DE MAN, A. W. A.; VAN DER LAST, A. R. M.; KNIPPENBER, K.; FRIJNS, J.; VAN BUUREN, J. C. L. Anaerobic treatment of domestic sewage and wastewater. Water Science and Technology. v. 27, n. 9, p. 67-73, 1993.

LETTINGA, G.; HULSHOFF POL, L. W. UASB-process design for various types of wastewaters. Water Science and Technology. v. 24, n. 8, p. 87-107, 1991.

LEVENSPIEL, O. Engenharia das reações químicas. Tradução de Verônica M. A. Calado. 3. ed. São Paulo: Edgard Blucher, 2000.

LI, Y.; YU, J.; LIU, Z.; MA, T. Estimation and modeling of direct rapid sand filtration for total fecal coliform removal from secondary clarifier effluents. Water Science and Technology. v. 65, n. 9, p. 1615-1623, 2012.

LIMA, L. E. M. Análise numérica de jatos coaxiais turbulentos. São José dos Campos, 2007. Dissertação (Mestrado em Engenharia e Tecnologia Espacias/ Combustão e Propulsão). Instituto Nacional de Pesquisas Espaciais.

LIN, K.; YANG, Z. Technical review on the UASB process. International Journal of Environmental Studies. v. 39, p. 203-222, 1991.

MAHMOUD, N. Anaerobic pre-treatment of sewage under low temperature $\left(15^{\circ} \mathrm{C}\right)$ conditions in an integrated UASB-digester system. Wageningen, 2002. Thesis ( $\mathrm{PhD}$ in Environmental Technology). Wageningen University. 
MEDEIROS, R. C. Avaliação da remoção de giardia spp e cryptosporidium spp em processo de tratamento de esgoto sanitário. São Carlos, 2013. Tese (Doutorado em Engenharia Hidráulica e Saneamento). Universidade de São Paulo.

MIKI, M.K. Dilemas do UASB. Revista DAE. São Paulo. SABESP, ano 58, v. 183, p. 25-37, 2010.

NAHLE, C. The contact process for the anaerobic treatment of wastewater: technology, design and experiences. Water Science and Technology. v. 24, n. 8, p. 179-191, 1991.

NASR, F. A.; DOMA, H. S.; NASSAR, J. F. Treatment of domestic wastewater using an anaerobic baffled reactor followed by a duckweed pond for agricultural purposes. Environmentalist. v. 29, p. 270-279, 2009.

NNAJI, C. C. A review of the upflow anaerobic sludge blanket reactor. Desalination and Water Treatment. v. 52, p. 4122-4143, 2014.

NOYOLA, A. Anaerobic digestion applied to municipal wastewater treatment: facts and limitations of an adapted technology for Latin-America. In: Proceedings WEFTEC, 2004, New Orleans.

O'FLAHERTY, V.; COLLINS, G.; MAHONY, T. The microbiology and biochemistry of anaerobic bioreactors with relevance to domestic sewage treatment. Reviews in Environmental Science and Biotechnology. v. 5, p. 39-55, 2006.

OLIVEIRA, S.C.; von SPERLING, M. Performance evaluation of different wastewater treatment technologies operating in a developing country. Journal of Water, Sanitation and Hygiene for Development. v. 1, p. 37-56, 2011.

PANDEY, N.; DUBEY, S.K.; Upflow anaerobic sludge bed (UASB) based sewage treatment plant (STP) at Mirzapur, a review. International Journal of Environment Sciences. v. 3, n.8, p. 67-71, 2014.

PASSIG, F.H. Reator anaeróbio híbrido para o tratamento de esgoto sanitário. São Carlos, 2005. Tese (Doutorado em Engenharia Hidráulica e Saneamento). Universidade de São Paulo.

PATWARDHAN, A. W.; GAIKWAD, S. G. Mixing in tanks agitated by jets. Chemical Engineering Research and Design. v. 81, p. 211-220, 2003. 
PATWARDHAN, A. W.; THATTE, A. R. Process design of jet mixers. The Canadian Journal of Chemical Engineering. v. 82, p. 198-205, 2004.

PENNA, J. A. Estudo da metodologia do teste de atividade metanogênica específica. São Carlos, 1994. Tese (Doutorado em Engenharia Hidráulica e Saneamento). Universidade de São Paulo.

PERUMAL, R.; SARAVANAN, K. Comparison of hydrodynamic behavior of jet mixer for newtonian and non-newtonian fluids. Research Journal of Engineering Sciences. v. 1, n. 3, p. 45-51, 2012.

PIEROTTI, S.P. Avaliação da partida de reator anaeróbio de fluxo ascendente e manta de lodo (UASB), em escala real, sob condições hidráulicas desfavoráveis. São Carlos, 2007. Tese (Mestrado em Engenharia Hidráulica e Saneamento). Universidade de São Paulo.

PIVELI, R. P.; KATO, M. T. Qualidade das águas e poluição: aspectos físico-químicos. 1. ed. São Paulo: ABES, 2005. 285 p.

POPE, S. B. Turbulent flows. 1. ed. Londres: Cambridge University Press, 2003.

PORTO, R. M. Hidráulica básica. 4ª edição. São Carlos. EESC-USP, 2006. 540p.

PREZOTTI, J. C. S. Influência da taxa de filtração no desempenho de filtros rápidos de areia praticamente uniforme. São Carlos, 1990. Tese (Mestrado em Hidráulica e Saneamento). Universidade de São Paulo.

RAMOS, R. A.; NEDER, K. D.; QUEIROZ, T. R.; PAULA, R. B.; SOUZA, M. A. A. Avaliação das rotinas operacionais e de manutenção em reatores UASB: o caso das estações de tratamento de esgotos no Distrito Federal do Brasil. Revista AIDIS de Ingeniería y Ciencias Ambientales: Investigación, desarrollo y práctica. v. 3, n, 1, p. 108-119, 2010.

REYES-ÁVILA, J.; RAZO-FLORES, E.; GOMEZ, J. Simultaneous biological removal of nitrogen, carbon and sulfury by denitrification. Water Research. v. 38, p. 3313-3321, 2004.

SARAVANAN, K.; SUNDARAMOORTHY, N.; MOHANKUMAR, G.; SUBRAMANIAN, N. Studies on some aspects of jet mixers I: Hydrodynamics. Modern Applied Science. v. 4, n. 3, p. 51-59, 2010. 
SATO, N.; OKUBO, T.; ONODERA, T.; OHASHI, A.; HARADA, H. Propects for a selfsustainable sewage treatment system: a case study on full-scale UASB system in India's Yamuna river basin. Journal of Environmental Management. v. 80, p. 198-207, 2006.

SCHELLINKHOUT, A.; COLLAZOS, C. J. Full-scale application of the UASB technology for sewage treatment. Water Science and Technology. v. 25, n. 7, p. 159-166, 1992.

SCHIMIDELL, W.; LIMA, U. A.; AQUARONE, E.; BORZANI, W. Biotecnologia industrial. Edgard Blucher, 2001.

SEGHEZZO, L.; ZEEMAN, G.; VAN LIER, J. B.; HAMELERS, H. V. M.; LETTINGA, G. A review: the anaerobic treatment of sewage in UASB and EGSB reactors. Bioresource Technology. v. 65, p. 175-190, 1998.

SEGHEZZO, L. Anaerobic treatment of domestic wastewater in subtropical regions. Wageningen, 2004. Thesis (PhD in Environmental Technology). Wageningen Unversity.

SHUJA, S. J.; YILBAS, B. S.; BUDAIR, M. O. Influence of conical and annular nozzle geometric configuration on flow and heat transfer characteristics due to flow impingement onto a flat plate. Numerical Heat Transfer, Part A: Applications. Londres, v. 48, n. 9, p. 917-939, 2005. $560 \mathrm{p}$.

SILVA, F. J. A.; LIMA, M. G. S.; MENDONÇA, L. A. R.; GOMES, M. J. T. L Septic tank combined with anaerobic filter and conventional UASB - results from full scale plants. Brazilian Journal of Chemical Engineering. v. 30, n. 1, p. 133-140, 2013.

SILVA, S. Q.; ZERBINI, A. M.; CHERNICHARO, C. A. L. Diversidade microbiana em reatores UASB alimentados com esgoto sanitário e submetidos a diferentes condições operacionais. In: $24^{\circ}$ Congresso Brasileiro de Engenharia Sanitária e Ambiental, 2007, Belo Horizonte. Anais do $24^{\circ}$ Congresso Brasileiro de Engenharia Sanitária e Ambiental.

SINDALL, R.; BRIDGEMAN, J.; CARLIELL-MARQUET, C. Velocity gradiente as a tool to characterise the link between mixing and biogás production in anaerobic waste digesters. Water Science and Technology. v. 67, n. 12, p. 2800-2806, 2013.

SOUZA, A. M. Análise numérica da transição à turbulência em escoamento de jatos circulares livres. Uberlândia, 2005. Tese (Doutorado). Universidade de Federal de Uberlândia. 
SOUZA, C. L. Estudo quantitativo e qualitativo de escuma acumulada em reatores UASB tratando esgotos domésticos. Belo Horizonte, 2006. Tese (Mestrado em Saneamento, Meio Ambiente e Recursos Hídricos). Universidade Federal de Minas Gerais.

SOUZA, C. L.; CHERNICHARO, C. A. L.; AQUINO, S. F. Quantification of dissolved methane in UASB reactors treating domestic wastewater under different operating conditions. Water Science and Technology. v. 64, n.11, p. 2259-2264, 2011.

SOUZA, M. E. Criteria for the utilization design and operation of UASB reactors. Water Science and Technology. v. 18, p. 55-69, 1986.

SWITZEMBAUM, M. S.; GIRALDO-GOMEZ, E.; HICKEY, R. F. Monitoring of the fermentation process. Enzyme and Microbial Technology. v. 12, n. 10, p. 722-730, 1990.

TEBUTT, T. H. Y. Na investigation into tertiary treatmetn by rapid filtration. Water Research. v. 5 , n. 3, p. 81-92, 1971.

TEIXEIRA, A. R; CHERNICHARO, C. A. L.; SOUTO, T. F. S.; PAULA, F. S.. Influência da alteração da distribuição do tamanho de partículas no desempenho de reator UASB tratando esgoto doméstico. Engenharia Sanitária e Ambiental. Rio de Janeiro, v. 14, n. 2, p. 159-166, 2009.

TCHOBANOGLOUS, G.; BURTON, F. L.; STENSEL, H. D. Wastewater engineering treatment and reuse. $4^{a}$ edição. Nova York. McGraw Hill, 2004. 1819 p.

TONETTI, A. L.; CORAUCCI FILHO, B.; STEFANUTTI, R.; FIGUEIREDO, R. F. O emprego de filtro de areia no pós-tratamento de efluente de filtro anaeróbio. Revista Técnica da Sanepar. v. 21, n. 21, p. 42-52, 2004.

USEPA - United States Environmental Protection Agency. Process desing manual for suspended solids removal. Technology Transfer Offcice. EPA 625/1-75-003a. 1975.

USEPA - United States Environmental Protection Agency. Evaluation of full-scale tertiary wastewater filters. Municipal Environment Research Laboratory. EPA 600/2-80-005. Cincinnati. 1980.

USEPA - United States Environmental Protection Agency. Guidelines for water reuse. Office of Water. EPA 600-R-12-618. Washington. 2012. 
Van HAANDEL, A. C.; LETTINGA, G. Anaerobic sewage treatment: a practical guide for regions with a hot climate. New Jersey. Wiley-Blackwell. 1994, 236 p.

van HAANDEL, A.; KATO, M. T.; CAVALCANTI, P. F. F.; FLORENCIO, L. Anaerobic reactor design concepts for the treatment of domestic wastewater. Reviews in Environmental Science and Bio/Technology. v. 5, p. 21-38, 2006.

van LIAR, J. B. High-rate anaerobic wastewater treatment: diversifying from end-of-the-pipe treatment to resource-oriented conversion techniques. Water Science and Technology. v. 57, p. 1137-1148, 2008.

VIGNESWARAN, S.; KANDASAMY, J.; ROGERSON, M. Water and wastewater treatment technologies: filtration technologies in wastewater treatment. In: Encyclopedia of Life Support Systems (EOLSS), Desenvolvido sob os auspícios da UNESCO. Eolss Publishers, Paris, France, 2009.

von SPERLING, M. Comparison among the most frequently used systems for wastewater treatment in developing countries. Water Science and Technology. v. 33, n. 3, p.59-72, 1996.

VIEIRA, S. M. M.; SOUZA, M.E. Development of the technology for the UASB reactor in domestic sewage treatment. Water Science and Technology. v. 18, n.12, p. 109-121, 1986.

YVES, K.J. Review paper rapid filtration. Water Research, v. 4, p. 21-223, 1970.

WINKLER, M. K.; BASSIN, J. P.; KLEEREBEZEM, R.; van der LARS, R. G.; van LOOSDRECHT, M. C. Temperature and salt effects on settling velocity in granular sludge technology. Water Research. v. 46, p. 5445-5451, 2012.

ZUGHBI, H. D.; SIDDIQUI, S.W.; FATEHI, A. I. Mixing in a fluid jet agitated tank: geometric effects. Dev. Chem. Eng. Mineral Process. v. 14, p.143-152, 2006.

ZUGHBI, H. D. Numerical simulation of mixing in a jet agitated horizontal cylindrical tank. International Journal of Computational Fluid Dynamics. v. 20, n. 2, p. 127-136, 2007. 